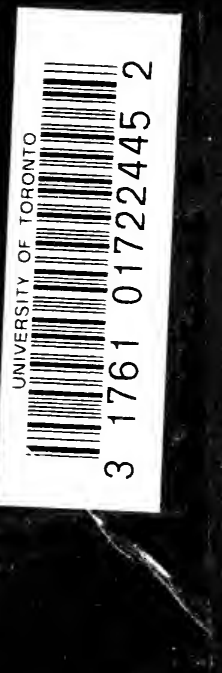


THR 
soung.

y1163 
Digitized by the Internet Archive in 2007 with funding from Microsoft Corporation 
NINETEENTH CENTURY EUROPE AND BRITAIN 
Uniform Witb Tbis Volume

G. D. H. Cole

THE LIFE OF WILLIAM COBBETT

Percy Ashley

TWICE FIFTY YEARS OF EUROPE

C. Raymond Beazley, D.Litt., F.R.G.S.

NINETEENTH CENTURY EUROPE

AND BRITAIN

Andrew Browning, M.A.

BRITAIN AS A EUROPEAN POWER 


\section{NINETEENTH CENTURY EUROPE AND BRITAIN}

BY

C. RAYMOND BEAZLEY, D.Litt,, F.R.G.S.

PROFESSOR OF MODERN HISTORY, UNIVERSITY OF BIRMINGHAM

LATE FELLOW OF MERTON COLLEGE, OXFORD HON. VICE-PRESIDENT OF THE ROYAL HISTORICAL SOCIETY CORR. FELLOW OF THE LISBON ACADEMY OF SCIENCES

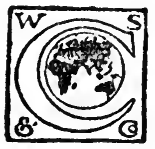

LONDON : 48 PALL MALL W. COLLINS SONS \& CO. LTD. GLASGOW SYDNEY AUCKLAND 
Copyright

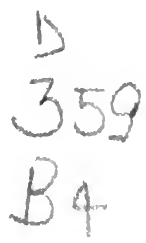

Noi 1972

Printed in Great Brilailn 


\section{PREFATORY NOTE}

IN this volume I have tried to give some results of independent work, and of University teaching, during the past ten years. Perhaps no period quite equals the Nineteenth Century as a 'torch to light us forwards as well as backwards,' and if we had followed that light more closely, the civilized world might have been less 'forwandred' to-day.

In the opening paragraphs of the book itself I have summarized certain conclusions and suggestions which have helped to guide me.

Instead of inserting geographical sketches and plans, necessarily rather meagre on a small page, I would refer readers to the more excellent way of consulting such a handy, scholarly, inexpensive, and altogether admirable map-collection as Robertson and Bartholomew's Historical Atlas of Modern Europe, I789-I9I4 (Oxford, I9I5).

The Additional Notes on civilization- or culturehistory, at certain epochs (e.g. I8I2-I5; I870-7I), only attempt to deal with a select number of outstanding and representative years. Even a slight survey of this field, as a whole, throughout the time here considered (I8I2-I9I8), was out of the question, much as I could have wished otherwise. And, in particular, I thought it best not to try anything on this side after the Franco-German War (I870-7I). But I hope what has been tried may be of use. No 'general 


\section{PREFATORY NOTE}

history' can afford to leave out civilization in sketching political progress. And least of all can it do this in the Nineteenth Century, among all the later ages.

The special subject of my studies and interest for some time past has been the Bismarckian age and its sequel, and I hope I may be able to follow up this volume with others. It is difficult not to feel the overmastering importance of these last tragic years, and historical research seems now to have a remarkable opportunity of dispelling some of the fogs of Darkest Europe, and suggesting a Way Out.

My warmest thanks are due to the authorities of the British and French Foreign Offices, and especially to the late Marquess Curzon of Kedleston, for so generously giving me access to the Archives, and particularly to Archives of recent date. 


\section{CONTENTS}

char.

I. The Fall of the French Empire, I812-I5 - II

II. The Vienna Settlement, I8I4-I5 - - 34

Additional Note on Culture-History, I812-15 - 47

III. The Earlier Age of Peace, I8I5-r854 - - 49

Additional Notes on Culture-History, r829-3I, and 1848-50 - - - - - $\quad 70$

IV. The Crimean War, The Eastern Question, and The Treaty of Paris - - - - 73

Additional Note on Civilization-History, I853-56 - - - - - - - 97

V. Italian Unity and Other Changes, 1857-61 - 98 Additional Note on Culture-History, 1859-6I - II2

VI. The Beginnings of the Bismarckian Age, $1859-63$ - - - - - - - - II3

VII. The Unity of Germany - - - - - $\quad$ - 132 Additional Notes on the History of Culture, I865-66; I870-7I - - - - $\quad$ - 198

VIII. RECONSTRUCtION AND THE EASTERN QUESTION - 202

IX. The Later Bismarckian Time, 1879-90 - - 225

X. From Triplice to Triple Entente, r890-19I4 - 246

EPILOGUE-THE WORLD WAR OF I9I4-I9I8 - 279

NOTE ON BIBLIOGRAPHY - - - - - 321

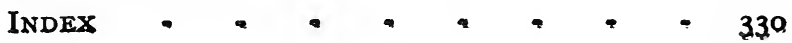





\section{NINETEENTH CENTURY EUROPE AND BRITAIN}

\section{BRITAIN AND EUROPE, I8I2-I9I8}

What we mean by Nineteenth Century Europe-the time of our fathers and grandfathers, which followed the storms of the Revolution and the Napoleonic age -is usually treated as beginning with the Congress and Settlement of Vienna, and most often with the final results of the Congress, after the interruption of the Hundred Days and the final surrender of the French Emperor. But a commencement may also be made with the fall of that Empire, with the retreat from Moscow and the uprising of Nationalism against the universal Napoleonic ambition, first in Russian, then in Germanic, Europe.

It is easy to see now that this 'Nineteenth Century' time in Continental History from I8I2, is, above all, Germanic and Russian. Among modern ages it is the special German period, as the seventeenth century and the epoch of the Revolution are the peculiarly French periods. Next to the German interest in these years comes the Russian; never did Russian prestige stand so high as in the last years of Alexander I., between 
I8I2 and I825; until the Crimean War Russia, however undeservedly, retained something of a premier position among the Great Powers, Britain apart. Only in the nineteenth century did Russia seriously begin her remarkable contribution to modern culture. From a time only a little subsequent to the Crimean struggle, German nationalism, directed by Prussia, gradually comes to lead the politics, as German intellect had already begun, in so many fields, to lead the thought of Europe. Long before the great days of German unity, even from the early days of the Monumenta Germaniae Historica (c. I820), German research was exercising an extraordinary influence. Did not British learning, for example, acquire a habit of looking at things through German spectacles? And in most of Ranke's life (I795-I886), as for some time after his death, German literature seemed the equal of any and the superior of most. Brilliant and memorable as are the achievements of French or Italian genius in the last century, it is not, as an age, outstandingly French or Italian. Louis Napoleon, Cavour, or Victor Hugo are representative of nations and movements of deep and wide significance ; but they are not so typical of the central activities of Continental Europe in these years as Bismarck, Goethe, Skobelev, or Tolstoi. 


\section{CHAPTER I}

THE FALL OF THE FRENCH EMPIRE

$\S \mathrm{I}$. The Russian Campaign of I8I2

When Napoleon finally broke with Russia, whose alliance since 1807 , sealed by the Peace of Tilsit, had been a mainstay in his system and his power, in their fullest extension, he opened the direct way to a new age arising from his own overthrow.

The ruin of that French domination in Europe, which had begun some twenty years before, and had over-shadowed nearly all the non-Russian continent for seven years, was prepared and made possible by the hideous disaster of the retreat from Moscow.

In the Grande Armée which Napoleon led into the heart of Russia were about 650,000 men; of this force 200,000 French formed the core, the rest were really vassal troops, some enthusiastic, some willing, most reluctant. Poles, to whom the French were deliverers, marched with Austrians and Prussians who dared not refuse the 'alliance' of their overlord or oppressor. To meet this host Russia had in the field little more than the third of Napoleon's numbers. The crowned adventurer, incomparable in military genius, in organizing power, in activity and success of every 


\section{2 NINETEENTH CENTURY EUROPE}

kind, was now able to throw upon the Slav empire, it would seem, most of the European continent. 'Never was the success of an expedition more certain'. . 'I feel that it draws me on.' On his way to the Russian front, then marked by the courses of the Niemen and the Polish Bug, Napoleon stopped at Dresden with his new Austrian empress (May I8I2). It was like the visit of a god and not of a man. All the leading German sovereigns were there to meet him, the Hapsburg emperor and the Prussian king among them. Four crowned heads were sometimes observed together in Napoleon's ante-room waiting for an audience; queens were ladies-in-waiting to Maria Louisa.

The conqueror ' acted the host in the house of his Saxon vassal, inviting his Imperial father-in-law to dinner every day, but the King of Prussia and the Master of the Castle, as people of inferior rank, only every other day.'

None of the 'well-informed' believed the victory, or even the effective defence, of Russia to be possible. All human reckoning seemed to work out inevitably the triumph of the French.

When, soon after midnight, in the earliest hours of Midsummer Day, the central columns of the Grande Armée, under the eye of the Emperor himself, began to cross the Niemen at Kovno-200,000 strong-a turning point in history was reached. The world had seldom seen a more powerful and magnificent array than the host which now commenced the Second Polish War. Six months later, the ruin of that host had shaken the foundations of the French empire and of the Continental system of the new Charlemagne, and 


\section{FALL OF THE FRENCH EMPIRE 13}

had prepared the fall of the Revolution and of its master.

Napoleon penetrated, in apparently easy triumph, and with only one pitched battle, to the heart of Russia, forcing back the troops of the Tsar on the hard-fought field of Borodino on September 5 th and entering Moscow on September I4th. But the Russian policy had been to lure him on, relying on the geographic side of Russian defence-the difficulty of disabling a body so enormous, the still greater problem of a thorough conquest, the danger of an invader's communications, the perils of retreat.

When Napoleon reached Moscow, instead of deputations of submission and offers of peace, he found a deserted city. From among the vagabonds, thieves, and stowaways who remained, mostly in hiding, the French troops unearthed one of their countrymena bookseller.

'Where is the Senate?' Napoleon asked him. 'It has gone away.' 'And the Governor ?' ' $\mathrm{He}$ has gone.' 'Where are the people?' 'There are no people.' 'Who is there in the city ?' 'Nobody.' 'It can't be so.' 'I swear it is, on my honour.' 'Be silent.' And the Emperor, frowning, himself relapsed into moody silence. The Russian leaders, as they said, had given up Moscow, 'that the wolf might fall into the trap.'

More clearly still did Napoleon see this when, on the day after his entry, the city burst into flame.

The Governor, before departing, had fired his own country house in the suburbs of Moscow; but to put the torch to the boudoir of his dead wife was a duty that he laid upon his friend and guest, Sir Robert Wilson. 
'These are Scythians indeed,' exclaimed the conqueror, as he saw the sheets of flame spreading around the Kremlin. 'Moscow no longer exists ; the Russians are consuming it themselves-what a people!'

The burning of Moscow began on the night of the I6th of September, but Napoleon, as if fascinated by some serpent of evil-counsel, could not bring himself to quit the ruins of the ancient capital, and waited, with unwonted irresolution, the oncoming of the most terrible of Russian generals, and the gathering of the human enemies who now increasingly threatened his outposts and his connections.

Still the French Emperor clung to the obsession of the Tsar's submission near at hand. Almost daily he expected to welcome the submissive envoys of Alexander.

But Alexander, ${ }^{1}$ drawing fresh courage from the iron resolution of Stein, who had come to the Russian court to carry on the work that had been interrupted in Prussia, had little thought of yielding.

Soon Napoleon 'the conqueror' began to make advances; the 'defeated' Tsar gave no reply to his enemy. But to his friends he declared : 'I will grow a beard, and live on bread in the wilds of Siberia, rather than subscribe to the shame of my country. Either Napoleon or I-I or Napoleon-we cannot rule together. I have learned his character, he will deceive me no more.' He forbade his generals to receive any offer of peace, or discuss any terms.

At last, on the Igth of October, in the face of rapidly approaching winter, Napoleon left Moscow, falling back

${ }^{1}$ Son of Paul, grandson of Catherine II., Emperor of all the Russias, 1801-1825. 


\section{FALL OF THE FRENCH EMPIRE I 5}

south-westwards, with the object of securing a retreat through the unwasted territories of the Ukraine. With him marched roo,000 men; most of the rest of the Grande Armée had been detached for communications and for subsidiary action. But north of Kaluga, at Malo-Yaroslavets, name ever memorable to Russian patriots, the French were headed off by so stubborn a resistance and so dangerous a threat of encirclement, that, after some wild words about marching on St. Petersburg, retreat was ordered along the old line of advance, devastated and foodless as it was.

The Russian forces, both organized troops and guerilla bands, hung upon the invader's flanks and rear. The whole countryside of Russia seemed to have taken arms, and Napoleon felt, as perhaps never before, the meaning of universal and national resistance.

Meantime the cold came on like a tide; the winter was terrible, even for Russia. The French were quite unprepared for such conditions. The thin blue uniforms could not resist the razor-like wind, still less the frost, which by November 6th was already deadly.

The commissariat failed ; Napoleon's hopes of vast provision stores at Smolensk were disappointed; the enemy attacks redoubled; discipline melted away; cannon were sacrificed by hundreds, men by thousands. In the passage of the Berezina and in the last stages of the retreat from the Berezina to the frontier, the French fortunes reached their nadir.

Broken bridges; whole battalions in the icy river; the Russian artillery ploughing through the ranks upon the shore; French rearguards cutting their way through countrymen and allies in front; the remnants 


\section{I6 NINETEENTH CENTURY EUROPE}

of the Grande Armée struggling on in rags, starving, frost-bitten, falling by the 'roadside' (though road there was none); some tatterdemalions tied up with frozen handkerchiefs or fragments of women's dress ('cuirassiers in petticoats'); some, more fortunate, robed in sacerdotal garments warm and heavy, taken from the churches; eating horses, offering for bread their watches, rings, or money-thus the remnants of the host recrossed the Niemen in mid-December and re-entered friendly Poland.

Of all the invaders who had entered Russia at midsummer, only 80,000 could again be rallied.

One hundred and twenty-five thousand had been killed; one hundred and thirty thousand had died of cold, famine, and fatigue; nearly two hundred thousand were prisoners; well-nigh eighty standards and a thousand cannon had been abandoned. Those who escaped included the bulk of the Austrian and Prussian contingents. The heaviest loss of all had fallen upon the French themselves.

\section{§ 2. The War of Liberation in $\mathrm{I} 8 \mathrm{I} 3$}

It was with a courage and audacity worthy of himself, the 'Super-Man,' that Napoleon faced the situation. 'The Grande Armée is destroyed ; his Majesty's health has never been better'-thus on December I7, I8I2, the Moniteur declared, in the Twenty-Ninth Bulletin, that model for heroes in adversity. With the same sangfroid the Emperor declared to his Polish friends that with a fresh army of 300,000 he would soon stand on the frontier of Russia once more, as powerful as ever. 
He had no conception of the new racial feelings of the Germans, brought to birth by his own rule; and he still underrated the danger in Spain, where Wellington had just won Salamanca ${ }^{1}$ and penetrated to Madrid, but had been compelled to fall back. Also he might well build hopes on the success of his American diplomacy and the mistakes of Britain. The United States had just declared war afresh against their old enemy. Might not this fatally divide and weaken English hostility to the French Empire?

But the German consequences of the Russian War altered the whole situation. 'You may shake your chains,' Goethe said in despair, even now, 'you will never break them,' and on this, or an even duller submissiveness, Napoleon even now confidently reckoned. His reckoning was false.

Since I789, even since $I 806$, a new spirit of race and nationhood had been breathed into the Teutons, and by the last days of I8I2 every German Nationalist was trembling with the hope, or the conviction, that the hour of deliverance had come.

'Now or never,' said one of the most cautious and conservative of the Prussian State Council, 'now or never must the foreign yoke be thrown off, unless

${ }^{1}$ July 22. By this campaign, though unsuccessful in emancipating the capital and the Castilian plateau, Wellington compelled the French to abandon the south of Spain, in order to save their position in the centre.

Sir Arthur Wellesley-born 1769, died 1852-one of the creators of the British empire in India (battle of Assaye, 1803) had commanded the British forces in Spain and Portugal since the spring of 1809, winning Talavera in July (after this Lord Wellington), holding the lines of Torres Vedras in 1810 , etc. He became Duke of Wellington after the overthrow of the French in Spain, 1813. His statesmanlike moderation secured the passage of the Reform Bill of 1832 in the Lords.

N.C.E. 
independence be renounced for this generation, perhaps for ever.' ' Now or never,' wrote General Yorck in a letter 'signed with his heart's blood' from the seat of war.

The convention which Yorck concluded at Tauroggen mill with the Russians, by which the Prussian contingent of the Grande Armée became neutral, was the first symptom of defection from the French ' alliance,' the first sign of revolt against the French domination (December 30, I8I2).

Vigorous action on the part of Yorck and his Prussians at this moment would have vitally benefited the French cause ; the Russian forces, faint, though pursuing, their efficiency woefully diminished, might have been held along their western frontier for some time at least, perhaps until Napoleon could return with a flood of reinforcement. But the armistice of Tauroggen opened the north-east frontier of the German world, the East Prussian border, to the Russian advance, and the Slav liberators crossed the Niemen, entered Königsberg, crossed East Prussia, crossed the Vistula, poured into Poland, broke up on all sides the French defence in Eastern Europe.

That defence, leaving only garrisons in some of the chief Polish fortresses, such as Thorn, after vainly attempting to make a stand on the Posen line, was forced back upon the Oder in mid-February, and so upon the Elbe in early March.

Berlin itself had to be abandoned on March 2; and the whole of Prussia (as that truncated state had existed since Jena and Tilsit), was soon cleared of the field forces of its Gallic ' allies' : isolated garrisons only remained. 


\section{FALL OF THE FRENCH EMPIRE I 9}

The action of the Prussian Government, after Yorck's Convention, guided by the King ${ }^{1}$ and the Chancellor, ${ }^{2}$ both efficient learners in the school of adversity, showed statecraft of an order very different from the Berlin policy before Jena. Yorck had been instructed 'to act according to circumstances.' He naturally interpreted this direction as a hint that the detested alliance of Prussian vassals and French overlord was soon to end; nor was he wrong. But the manner of ending that alliance was to be neither so sudden nor so perilous as Yorck supposed.

It was a matter of the utmost consequence for Prussian and German Nationalists to gain time, to unite forces, to link themselves with their new helpers, to complete their preparations.

Yorck's action, therefore, was disavowed; he was superseded in his command; negotiations were opened for the marriage of the Prince of Prussia with a Princess from among the Murats or the Beauharnais (January, I8r3).

The Prussian Chancellor himself, in those anxious days, developed an exceptional and surprising fondness for the society of French generals and diplomatists. There was a constant exchange of dinners, receptions, and hospitalities of all sorts between Hardenberg and his French masters. And to Paris was now sent a well-known and sincere advocate of the French alliance or supremacy, 'one of the stupidest' of ambassadors, completely ignorant of the real policy of his government. Such a man as Prince Hatzfeldt could

${ }^{1}$ Frederick William III., I797-I840 [Jena I806: Tilsit I807].

${ }^{2}$ Karl August von Hardenberg, I750-1822 ; Chancellor, I810 ; Prince, 1814. 
truly repudiate at the Tuileries that 'treachery' of Yorck's which Hardenberg in Potsdam and Berlin was so fervently disclaiming, with so little sincerity. Yorck had 'staved in the cask too soon' : false tongue must hide what the fierce heart would show.

In spite of many suspicions, these tactics were not unsuccessful. By the evening of January 23 all was ready, and Frederick William left Potsdam (still perilously open to French attack) in a more fortunate flight than that nightly flitting of French royalty to Varennes which had proved the ruin of Louis XVI. Silesia, now emptied of French troops; already near to the emancipating Russians, who daily came nearer still ; and full of the enthusiasm for the War of Liberation, was chosen for the land, and Breslau for the city, of refuge. Secret embassies to the Russian and Austrian courts had already concluded a practical alliance with the former, and established conditions of friendly neutrality with the latter.

Step by step Hardenberg and his sovereign approached their goal. The Prussian preparations for war, and for war on a great scale, had been incessant since the end of December, but until this moment the pretence of vigorous participation on the side of the French ally had been, on the surface and in official quarters, perfectly maintained.

Popular feeling, of course, had already sometimes shown itself in a very different manner. 'On all the roads were reservists returning to their regiments, dimly recognising for what purpose ... The French became increasingly uneasy as they encountered these remarkable allies. They could not fail to notice their fierce glances, their threatening tones. ... Under the 


\section{FALL OF THE FRENCH EMPIRE 2 I}

eyes of the enemy had to be marshalled the army for the defeat of the enemy.' And both the extreme caution and the deep craft of the government, alike indispensable, were wanting among its soldiers.

But the Prussians were helped by the contemptuous oversight of their great adversary, who only watched the official world. "The Prussians are not a nation; they have no national pride; they are the Gascons of Germany.' Thus Napoleon put aside warnings, oft repeated, emphasised in these last months by the ablest and most trusted of his lieutenants.

Even in March the Emperor declared that Prussia could not raise more than forty thousand men, or put in to the field above twenty-five thousand.

But already, on February 3rd, Frederick William by his appeal 'To my people,' and the people by their response to that appeal, had begun to reveal the truc state of things, and a Prussian army of two hundred and seventy thousand men began to gather.

Scharnhorst, who had so long re-organised the secret military strength of the monarchy, in its depression after Jena, drew up the plans for the joint action of Slav and Teuton against the French, and on February I3th what was truly an ultimatum was sent to Paris. Yet all this time the heads of the Prussian government, remaining at Berlin, preserved, according to instructions, the best of outward relations with the French military authorities.

At last, on February 28th, the Treaty of Kalisch was signed, and the scabbard thrown away. The Tsar bound himself to restore Prussia to the position she had held before the campaign of Jena. The Russian government guaranteed to their ally the whole of Old 


\section{2 \\ NINETEENTH CENTURY EUROPE}

Prussia, together with a Polish strip (that Posen region which linked Silcsia and West Prussia), and such acquisitions in North Germany as would compensate Prussia for her sufferings, for her services against the common foe, and for her retirement from so much of her Polish gains of I793 and I795, mischievous and untenable as they were.

On her side, Prussia practically resigned to her Eastern neighbour and dear friend those same Polish lands, from Warsaw to the Warta, so eagerly coveted by the Russian statesmanship of the time, so devoted and helpful to the French deliverer, so gladly resigned by Frederick William III. 'Many thanks, I have had enough of them already.'

By the League of Kalisch, a new Grand Alliance, which was to succeed where so many had failed, and to overthrow the Napoleonic system and power, came into being. To this League Britain, almost perpetually in arms against France since 1793, was an inevitable accessory. Equally natural was the help of the Spanish insurgents, or patriots, now in the fifth year of their own War of Emancipation. On March

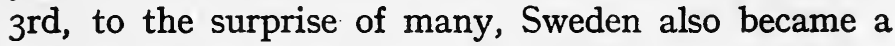
partner in the confederacy. And hardly less inevitable, in her own interests, might seem the future aid of Austria. But Vienna hesitated as yet, waiting for ' the God of Battles to throw his iron dice.'

By the Treaty of Kalisch Russia agreed to put into the field a hundred and fifty thousand men, Prussia little more than half that number, but the real conditions were for a long time almost reversed.

Not until the autumn did the Russian army reach the stipulated strength ; from the beginning, the forces 
of her ally were greatly in excess of the bond. For she now devoted her whole manhood-one in seventeen of her people-to the struggle.

Alexander joined Frederick William at Breslau on March I5th, and now even Hardenberg admitted the breach with France. The 'War of Liberation' had begun in Germany.

At the opening of the campaign the Elbe was the practical boundary between the combatants, as far as the Bohemian mountains. Various fortresses beyond this line, Danzig and Stettin in Eastern Germany, and some of the chief entrenched camps of Poland, were still in French hands. But from Hamburg to Dresden the central German river marked the general frontier well enough.

In the first operations of $18 \mathrm{I}_{3}$ the Allies began by an ineffective offensive. In the battle of Lützen, near the scene of the last victory and death of Gustavus Adolphus, victory remained with Napoleon, but except for the wounds of Scharnhorst, it was rather a Pyrrhic victory (May 2nd). The French Emperor reoccupied Dresden, but with heavy losses, and with no decisive breaking of allied strength and will. Only in the death of the reformer of the Prussian army did the French secure a notable advantage - the neglected wounds of Lützen, aggravated by journeys to secure the aid of Austria, closed the career of Scharnhorst on June 28th.

The battle of Bautzen (May 2oth-2Ist) gave Napoleon some further gain of ground, completed his mastery once more of Saxon land, and forced the Allies back into Silesia and towards Berlin, but again failed to bring decisive victory. "They will not leave me a 
nail.' The French ascendancy in Germany, as in the Russia of I8I2, was now confronted by national resistance, not by the kings and courts of old days. Yet the full deliverance of Europe, or even of Germany, seemed to recede. Allied hopes paled. The boasts of Napoleon as to what his power could yet accomplish, despite 1812, seemed in a fair way of fulfilment. Could he play the part of statesman as well as he still did the work of commander, he might yet compromise, and secure enormous gains. Everything depended on the attitude of Austria. Both sides, severely mauled and much exhausted, hopeful and despondent by turns, were glad to conclude a truceno preliminary to peace, but a breathing space for the renewal of war. On June 4 th the armistice of Pleswitz was signed ; again and again renewed, for short periods, it suspended the duel until August I2th.

Deep depression prevailed in the Allied camps and courts, from London to St. Petersburg. Napoleon's spirits rose to their old heights of confidence and arrogance, and he failed to realize the imperious necessity of conciliating Vienna by solid concessions.

Much turned on Illyria. The Hapsburg State was cut off by this French acquisition from access to the sea, and its restoration was naturally made a vital matter. But far more lay behind. As Napoleon was heard to exclaim: 'Peace is only a pretext with you ; you want to dismember the French Empire. Ah, Metternich, ${ }^{1}$ how much has England given you to make war upon me ?'

${ }^{1}$ From 1809 to 1848 Prince Metternich is the leading Austrian Minister and director of Austrian policy. 
The Austrian demands were concentrated on four points: The cession, or restoration, of Trieste and the Illyrian Provinces; the abolition of the Duchy of Warsaw, and its repartition between Russia, Prussia, and Austria ; the replacement of Prussia in its former position and territory; and the restoration to independence of the German North Sea coast, or at least of Hamburg, Bremen, and certain other parts of that littoral.

The stormy violence and intractability of Napoleon in the negotiations, the accession of Sweden to the anti-French coalition, the victories of the Allies in Spain at this very time (the news of Vittoria ${ }^{1}$ reached Dresden on June 3oth), and, not least, the firm attitude of the Russian and Prussian governments, which declared that in case of need they would continue the war without Austria-all contributed to force the decision, and to force it against Napoleon.

On August 7 th the Austrian ultimatum was handed in ; it insisted on the Four Points mentioned above.

'General Bonaparte's' answer (on the roth) yielded on some matters and compromised others, but added the demand, somewhat absurd except from an absolute conqueror, that the Confederation of the Rhine ${ }^{2}$ should be extended to the Oder. Austria accordingly declared war upon France on August the I2th, I8I3.

${ }^{1}$ By this crushing defeat of the retreating French, falling back from Madrid and Central Spain towards the Pyrenees (June 21, 1813), the Anglo-Spanish armies, under Wellington, practically cleared the Peninsula of the Napoleonic invaders who entered it in 1808, and retained control of the capital and most of the open country till late in $18 \mathrm{r} 2$.

2 The great league of South and West German States in alliance with France, with Napoleon as 'Protector,' which was formed in July, I806, and subsequently developed. 
On the resumption of the campaign, Napoleon was lured into an advance against Silesia, while the main force of the Allies moved upon his flank and rear from Prague to Dresden.

Immediate and vigorous attack might have given the city to the coalition, and the French Emperor with his main army would thereby have been put into the utmost danger.

But delay and indecision enabled Bonaparte to return by forced marches (covering forty leagues in four days), just in time to save the Saxon capital, and to win his last real victory on German soil. ${ }^{1}$

The main loss, and the main disgrace of the reverse, fell upon the Austrians, but the completeness and brilliance of the French success, the confusion and reproaches of the Allied retreat, produced once more, and for the last time, a chance, some have thought, of preserving the Napoleonic Empire in its main features and general extent.

'Had Napoleon at this moment made overtures' of sufficient moderation 'they might have been listened to,' but the cup of triumph was almost instantly dashed from his hands.

Four terrible defeats now befell the French in the outlying parts of the theatre of war. By these disasters the whole aspect of the campaign was vitally altered.

On one side, the attempt to cut off the Allied main army in the Bohemian mountains was foiled with heavy disaster to the French, Marshal Vandammes with I0,000 of his men being captured instead. ${ }^{2}$

1 Battle of Dresden, Aug. 26 and 27, 1813.

2 Battles of Kulm and Nollendorf, August 29 and 30. 


\section{FALL OF THE FRENCH EMPIRE}

Even before Napoleon had won the battle of Dresden, disaster had begun to fall upon the detached forces of his Marshals.

In the battle of Grosbeeren French attempts to re-occupy Berlin were defeated (August 23rd). On the first day of Dresden Blücher ${ }^{1}$ won his famous victory of the Katzbach with the Silesian army (August 26th). And a few days later Marshal Ney, who had been sent with considerable forces to renew the attack on Berlin, came to grief in the battle of Dennewitz (September 6th).

Everything was changed by these events. The endless marching and counter-marching, 'the everlasting va et vient' of which the Little Corporal complained so bitterly in those months of undecided fate, was over. Destiny was declaring definitely and irrevocably against the French.

The main allied ' army of Bohemia,' fully recovering from its misfortunes and confusion, and repulsing a fresh attack of Napoleon's in the border mountains of Saxony (on September I 7 th) moved forward again, while the armies of Silesia and the North forced the passages of the Elbe (in early October). Thus from three sides-south, east, and north-the converging forces of his enemies now threatened to surround and destroy Napoleon in the Dresden region.

A startling proof of altered fortune and altered feeling was at this moment afforded by Bavaria. This favoured vassal of the new Charlemagne, so long a mainstay of the Rhine Confederation, and a home of

1 The leading Prussian commander, and the most famous, as Gneisenau was the ablest, of the Allied Generals (apart from Wellington). Born I742 ; Field-Marshal, Oct. I813; died I8I9. 
French influence in the heart of the German world, so apparently impervious to nationalism in the strength of its particularist jealousy of the two great Teutonic powers, now abandoned Napoleon, joined in alliance with Austria, and threatened the rear of the Grande Armée in Germany, imperilling its existence.

To minimise these dangers, while yielding the least possible (a far deeper retreat towards the Rhine might have been safer and more fortunate), Napoleon abandoned Dresden, fell back on Leipzig, and there concentrated his forces for a decisive struggle. (Oct. I5.)

On the immense battlefield of the Saxon plain, where from north, south, and east, the confederate columns slowly drew near to the great semi-circle of the French position, the struggles of a generation, the "Wars of the Revolution,' were really brought to an issue.'

The Battle of the Nations raged from the I6th to the Igth, with cessation on the I7th. On the first day, only Blücher and the Prussians, on the north, gained any marked success; but on the third day, in spite of the heroic valour of the French, and the still unclouded genius of their leader, the Allies gained ground at every point; large masses of Napoleon's Saxon and Württemberg confederates joined their German brethren ; and by evening the Gallic hosts were driven back to the gates of Leipzig, and their Emperor himself bowed to the fact of defeat and the necessity of withdrawal.

On the final day, as the French were in full retreat over the Elster-here spanned by a single bridge-

1 After the battle German legend told how eight Emperors of the Holy Roman time had risen from their graves beneath the cathedral of Speyer, had crossed the Rhine by night, and had hurried to Leipzig to join in the combat. 
the Allied masses forced their way into the city on all sides, the bridge was blown up, and the only safe and regular exit was thus destroyed.

Many of the fugitives, at their head Prince Poniatowski, the chief commander of the Polish legion, were drowned; a marshal of France and twenty-one other generals were here made prisoners; another marshal - the famous Macdonald-swam the river.

Napoleon began the Battle of the Nations with nearly I80,000 men; he left behind about a third of this mighty force. But the Russian, Prussian and Austrian troops at Leipzig, raised by their last reinforcements on the I8th to over 280,000 men, formed perhaps the largest army that had yet taken part in a pitched battle in modern times.

The defeat was fatal for the Confederation of the Rhine, for the French dominion in Germanic lands, and (essentially and ultimately) for the whole fabric of the French Empire, Revolutionary and Napoleonic.

The French eagles recrossed the Rhine in the first days of November I8r3. The French garrisons in Central Europe had mostly surrendered before the end of the year; and by the opening of I8I4 only some five towns and two citadels remained in French hands, beyond the limits of the France of 1800 , beyond the Région française of Revolutionary conquest, with its border at the Rhine

\section{§ 3. The Campaign of $\mathrm{I} \mathrm{I}_{4}$ : the Fall of Napoleon}

The campaign in $I 8 \mathrm{r} 2$ in Russia had undermined the French world-power; the struggle of $\mathrm{I}_{8} \mathrm{r} 3$ in Germany and Spain had destroyed it outside the 
territories of the Consulate; the events of I8I4, on one side, seemed to make a full end of the French Revolution itself, and of the great revolutionary soldier, while, on another side, they opened a new settlement of Europe with the Congress of Vienna.

Even as late as the November of I8I3, terms of peace had still been offered to Napoleon, which while sweeping away the Imperial acquisitions beyond the Rhine and the Alps, yet left to France the frontiers of I800 on the German side, and of I795 on the Italianthe course of the Rhine from the Netherlands to Basel, the main chain of the Alps from Geneva Lake to the Mediterranean. But as the Emperor was still obdurate, and treated this sibylline offer with disdain, the Allies crossed the Rhine in the latter days of December.

Napoleon hardly ever executed more brilliant movements than when almost at the last gasp, in the series of lightning attacks by which he four times defeated separate divisions of the Prussian army, and twice worsted the main force of the Confederates in the Champagne country (January-February, I8I4).

In a fit of depression after these reverses, not very creditable to allied unity or strength of will, it was decided, in the face of violent Prussian opposition, to offer even now the 'frontiers of 1792 '-in other words, a considerable share of early Republican conquests on German soil. But fortune now seemed to have blinded her most favoured son, and his haughty and doubtful scrutiny of these terms forced the Allies into fresh resolution and fresh action.

The Continental invaders slowly closed in upon Paris with irresistible force, while the British invaders under Wellington, who had passed the Pyrenees, 


\section{FALL OF THE FRENCH EMPIRE 3I}

occupied Bordeaux, and proclaimed a Bourbon restoration, pushed into the south-west. ${ }^{1}$

A final and desperate effort of Napoleon's to throw himself upon the rear of the main army of his foes, to summon the frontier garrisons to his aid, and to call the whole population of France to arms, left the capital for the moment almost defenceless.

And, with a boldness for once almost equal to his own, the Allies disregarded all threats to their rear, pushed steadily forward upon Paris, and were masters of the city at the end of March (3oth-3Ist). The long conflict seemed at an end, and Napoleon abdicated, ${ }^{2}$ receiving from allied Europe the island of Elba as a sovereign principality, and retaining the Imperial title. Allied Europe now convened at the Austrian capital a great standing committee of its sovereigns and statesmen (to which Royalist France was soon admitted), to settle the affairs of the old civilized world.

\section{$\S$ 4. The Hundred Days and Waterloo}

In the midst of the work, the wranglings, and the social festivities of the Vienna Congress, and to the horror of its statesmen, Napoleon returned from Elba, mastered Paris and a great part of France, was joined by the bulk of the army, and for a 'Hundred Days' renewed the war.

Throwing himself upon the allied forces, British, German, and Netherland, quartered in Belgium under Wellington, Blücher and Gneisenau, he dealt the latter a heavy blow at Ligny, while Marshal Ney struck at

1 March 12th, fall of Bordeaux; April roth, battlc of Toulouse.

: At Fontainbleau, April 6th and Irth. 


\section{2 \\ NINE'TEENTH CENTURY EUROPE}

Wellington at Quatre Bras, without the same success (July I5th).

Although the English commander repelled the onslaught, the result of Ligny exposed him to great danger, and he fell back towards Brussels, taking up a strong position near Waterloo, a little south of the Belgian capital; while the Prussian leaders re-formed their forces at Wavre, slightly further to the east. Napoleon, detaching Grouchy, with over 30,000 men, to follow up and keep off his old enemies of the Katzbach and of Leipzig, pushed forward after Wellington with his main army, more than 70,000 strong, admirably equipped, with a very strong artillery.

Wellington faced this formidable host, one of the finest that Napoleon ever commanded, with a composite body of troops as seasoned, as stubborn, as efficient, and practically as numerous, but with a weaker supply of cannon and cavalry. And his 24,000 British, 30,000 Germans, and 13,000 Netherlanders, were not left unaided.

The battle began at midday, and before two o'clock the French command became conscious of the approach of the Prussian danger on their extreme right. Blücher and Gneisenau were slowly forcing their way back into the heart of the struggle, in spite of Grouchy.

After the miscarriage of his first great general attack on Wellington's lines Napoleon did not again, in face of the darkening cloud from the east, venture the bulk of his infantry in direct attack upon his enemy in front; part of his right wing, indeed, he now began to bend back for the protection of his threatened flank, while trusting in his splendid cavalry to break through and break up the Duke's positions. 
But, as in most modern warfare, the horse-soldier was constantly baffled by the footman, with the advantage of numbers, and with equality of strength, spirit, and endurance. Charge after charge did but involve the French in heavier losses and deeper failure.

Meantime the Prussian peril steadily increased, and before evening Napoleon was fairly overwhelmed. An unsparing pursuit, carried far into the night, irretrievably shattered the last army of the Revolution.

The Emperor, barely escaping, reappeared in Paris only to abdicate once more. Twenty days after Waterloo the victors entered Paris; soon the Bourbons returned, and the allied sovereigns, and 'everything as before'; and Napoleon, disappointed in plans of escaping to America, surrendered to the British.

This time there was no easy and dignified retirement to an Elba; the wrath and fear of his captors now consigned him as a prisoner of state to a remote island of the ocean.

In St. Helena, where European pioneers in the early Indian voyages so often stopped to repair and refresh, this mighty child of Europe, vainly looking yet again for restoration, fretted his last years away, weaving in these the web of a Napoleonic legend.

Like Louis XI., he would fain have persuaded the world that his only care was the good of man. ' Had God given me a few more years, I would have set all things in order.' 


\section{CHAPTER II}

THE VIENNA SETTLEMENT, I8I4-I5

The Congress of Vienna, that 'meeting of thrice accursed constables and lazy-bones' (as it seemed to a great, impatient soldier ${ }^{1}$ ), had to resettle Europe. And in spite of many a fault, and many an ignorance (and especially an inadequate realization of the claims of nationality and of democracy, the two chief moulding forces of the century), the Congress effected an European settlement which was not wholly without fairness and value, which gave rest to a troubled world, and which for forty years was not very seriously altered. For the French constitutional revolution of 1830 may be regarded, in the main, as a return to the constitutional monarchy set up in I8r4, and the Belgian and Greek risings only affected small nationalities and small areas. The European Concert of Great Powers, established at Vienna, was not shattered until the Crimean War (I854-6), nor was the position of any single Great Power or great race vitally modified till the same era.

Since the fall of Rome (4Io A.D.) western civilization, 'Europe,' ' Christendom,' had scarcely ever seen so long a period practically without war as now ensued

1 Prince Blücher. 
(1815-1854). And with the help of this Great Peace every form of culture, and especially the sciences of nature and of man, prospered marvellously. The new age was above all an age of inventions and of research.

The settlement was guided, perhaps, by four main principles. First, that of rewards and punishments - the spoils to the victors, recompense to the allies, retribution to the offenders. Secondly, that of precaution-to guard against the revival of the spirit of the French Revolution and the overlordship of that spirit in Europe. Thirdly, that of balance-to set up once more, and to preserve, a balance of political power. While, in the fourth place, the policy of restoring things as they were at the outbreak of the Revolution was followed, wherever possible-'back to I789.'

Under the First, we have the aggrandizement of Russia, Austria, Prussia, and certain other states on the continent; of Great Britain in the Mediterranean, the ocean, and the colonial world.

These territorial changes combine with other measures to satisfy the Second Requirement.

The efforts to realize the Third and Fourth involve a complicated and interesting series of arrangements which are constantly interwoven with the measures taken to promote the first and second points.

A. Among past services none were more conspicuous, none made more imperious claims, than those of

(I) Russia.

The Slavonic Empire was recompensed by the European ratification, tacit or expressed, of her recent gains in Finland (completely conquered from Sweden 


\section{NINETEENTH CENTURY EUROPE}

in I809); in Georgia and various other Caucasian lands (mostly acquired since r800); and in Bessarabia (won from Turkey in I8I2) ; as well as by the concession of Central Poland, not as a "province of the Vistula,' but as a constitutional kingdom, joined to the Tsardom only by 'personal-union'-the sovereignty of Alexander and his successors on the Russian throne. Here important compromises were effected with restored Prussia and reconstituted Austria.

(II) Austria was, in the main, except in Poland, restored to the position she had held at the beginning of the Revolutionary struggle. But in Italy, as in Istria and Dalmatia, her old possessions were increased by the territories of the extinct Republic of Venice (suppressed by Napoleon in 1797). Thus an interior bulwark, as we may call it, was erected against the French danger in the south-east. On the other hand, she renounced her far-outlying appanages in east and west-on one side, her Polish lands beyond the Vistula and the San, her footing on the Lower Bug ; on another side, the Austrian Netherlands, and various scattered lands or claims in South-Western Germany. Instead of any ' restoration of the empire to the Hapsburgs,' she was content with a nominal presidential position in the German Federation which now took the place of the Holy Roman state. Taught by bitter experience, she adopted concentration and moderation as fundamental principles.

(III) Prussia, more than any Great Power, had been geographically changed, and in all ways crippled and depressed, by Napoleon.

Now, in spite of many a jealousy and many a fear, she was not only to be restored, but strengthened. 
In the Middle East she acquiesced in the passing of much of her old Polish gains to the staunchest of her allies. Warsaw and all of the so-called 'New East Prussia' of I795, together with part of the 'South Prussia ' of I793 (her Polish seizures in the Second and Third Partitions), now went to the new constitutional monarchy of ' Congress-Polard,' under the sceptre of 'King' Alexander, the Tsar of All the Russias. On the other hand, Prussia retained Posen and all the western part of her annexations in Great Poland ('South Prussia '), together with the important city and great fortress of Thorn, upon the Vistula, in the north of the same province. Thus an effective connexion was maintained between West Prussia and Silesia. The Prussian government would perhaps have willingly sacrificed these relics of the Warsaw Grand Duchy to Russia, if Prussia could thereby have secured the whole of the Saxon kingdom. Russia was for a time resolute for the acquisition of all the Posen province, as Prussia for all Saxony; Britain, France, and Austria bitterly opposed in both cases. For a moment, the outbreak of a new European war was feared, hoped, or expected. But the danger passed; nowhere, except perhaps in Paris, was there any desire to renew the terrific struggles of the last years. The situation was saved by compromise.

In the south, about half of Napoleonic Saxony, including Wittenberg and the 'Luther country,' was acquired by Prussia.

In the north, she gained that part of western or 'Hither' Pomerania -with Rügen Island-which had hitherto remained Swedish, thus notably increasing her Baltic sea-board. 


\section{$3^{8}$ NINETEENTH CENTURY EUROPE}

While, in the west, her position was entirely transformed. From a minor partner in the Rhineland she now became the chief German power. From the Netherland frontier to the Moselle and the Saar, all the Rhine basin became 'Rhenish Prussia.' And with this went Westphalia. Cologne, Bonn, Coblenz, Trier, Aachen, Essen, Münster, Minden, became Prussian cities. Prussia was now the chief protector of the Germanic world on the side of France, as on the side of Russia. The most classic lands of German civilization passed under her rule. The Germanic character of her people and of her policy was infinitely strengthened; on the outer side, she turned away from her perilous expansion in Polish lands, sources of disaffection and weakness. No longer could anyone speak of the 'semi-Slav State.'

But the majority of the Congress would not permit this new Western Prussia to be linked up with the main block of the kingdom, any more than they would permit the absorption of the whole of Saxony. Between the two halves of the restored realm now stretched a corridor of lesser states, creations or revivals of the Viennese settlement. The chief of these was Hanover, still joined by personal-union with Britain, but inevitably tending to separation.

Although Prussian disappointment was loudly and bitterly expressed in some quarters ('We drove a fine bull to Vienna,' growled Blücher, ' and brought away a mangy old ox '), perhaps no continental power gained such solid advantage from the settlement.

For although some of Prussia's enemies hoped that the 'corridor' would become an ever-stronger arm of separation, and that Berlin would never be able effec- 
tively to assimilate the Rhineland, the opposite proved the case. In I866 Prussia annexed, with surprising ease, the intervening states, and, in Bismarck's phrase, made her frontiers ' sound.'

(IV) Sweden, whose desertion of the French cause -her traditional alliance-had been so useful since the spring of $18 \mathrm{I} 3$, was obliged to yield to Prussia her Pomeranian lands, but she obtained a rich recompense in her union with Norway. She thus retired for ever from that position oversea, on Germanic soil, which had been gained for her in the Thirty Years' War. Her similar retirement from the Russian side of the Baltic, practically enforced five or six years earlier by Alexander's conquest of Finland, was now ratified by the final cession of the same. On the other hand, her sovereigns at last became rulers of the whole Scandinavian Peninsula. One thing was lacking-the assent, or friendship, of Norway. The new Union was no union of hearts. Only force maintained it.

(V) Britain, ' the most constant,' and in many ways ' the most powerful,' if not 'the most generous,' of the foes of Revolutionary France and of Napoleon, found sufficient reward in the colonial world. In Europe she took as fruits of victory (if we put on one side the Protectorate over the Ionian Islands, renounced in I864) only Malta and Heligoland-the former a great fortress and harbour, of high historic fame, eagerly coveted by Napoleon; the latter a potential Malta of the north, but unregarded in naval matters till much later, when the islet passed into German hands and Prussian direction.

It was outside Europe that England found her chief rewards. Her Indian Empire had been consolidated 
in the wars of the last age; outside the Punjab there was now no native state, or league of states, which could venture on a contest with the new European suzerain ; the Mogul Emperors had become dependants of the East India Company.

The colonization of Australia had also been well begun; the whole of the sub-continent, equal to Europe in size, was now a British sphere of influence.

The vast Dominion of Canada was steadily maturing under the British crown; American hopes of conquest in the recent war (I8I2-I4) had been foiled.

From the unlucky Dutch, compelled so long and so unwillingly to follow their French overlords in the European struggle (since I795), Britain took the Cape of Good Hope, the basis of a South African Empire.

Holland also forfeited her vague rights in that Australia, which she had first truly opened to civilized knowledge, as well as various minor colonial possessions. For a time it even appeared as if the London government would insist on acquiring Java; but by a tardy justice, or by the ignorance of a Minister, this pearl of the East Indies was left to the Dutch.

From France Britain now legally and formally severed well-nigh all that remained of the old Gallic colonial empire-as it had stood at the outbreak of war in I793. Though not extensive, these losses served to bring out clearly the absolute disappearance of France, for the time, from the colonial world oversea; and the absolute dominance of Britain, save for the United States of America, in the same.

The punishment of offenders, so constantly the mere complement of the victors' recompense, involved not 
only the reduction of France to the limits of the old monarchy, the boundaries of 1789 , but the mulcting, in varied measure, of the aiders and abettors of the Revolution and of Napoleon.

The Grand Duchy of Warsaw, as we have seen, was abolished, to be re-divided mainly between Russia and Prussia, with an Austrian protectorate over the 'Free City' of Cracow. Among the Allies the Poles had no friends. Not even the British Government wanted a 'French outpost on the Vistula.'

The King of Saxony, who had also served Napoleon so well as Grand Duke of Warsaw, not only lost his Polish duchy, but half of his German kingdom. Narrowly did he escape with this: Prussian policy was set upon the acquisition of the whole-Dresden, Leipzig, and all. But here both Austria and Britain came to the rescue, while France was ever the steadfast and grateful friend. Vienna had no wish for any more extended frontier with Prussia; Silesia already afforded more than enough ; even a diminished Saxony was a useful ' buffer state.' Britain likewise took alarm at the 'grasping ambition' of Prussia.

Bavaria had to part with her Austrian Tyrol and with Salzburg, but, as in Saxony and Württemberg, her sovereign retained the Royal title Napoleon had created for his friend. The House of Wittelsbach had quitted the French cause just in time, and the future would show that the sympathies of these South Germans were vitally changing. No longer Francophile, they were slowly becoming Germanic.

The highlyartificial Kingdom of Westphalia, and other creations of Napoleon for the benefit of his House, or his allies, in north-west Germany, disappeared in order 
to establish the new Prussian lordship and guardianship on the Rhine and Weser.

Denmark, the ever faithful and unfortunate, deprived of her Norwegian partner, of Heligoland, and of her full sovereignty over Holstein (which now reverted to the position of a Germanic land under Danish protection), was definitely relegated to an almost obscure and quite powerless rank in the European and Christian family.

B. Among precautionary measures-arrangements to choke down any fresh outbreak of the "French danger' and the spirit of Revolution-were the restoration of old conditions, of the Ancien Régime, everywhere, as far as might be ; and the erection of geographical bulwarks, of some real stability in the military and political sense.

The former of these also belongs to the fourth and last of the guiding principles of the settlement; the latter has necessarily been implied, and noticed, to a large extent, in the first.

But while the Prussian bulwark on the Rhine, and the Austrian bulwark in northern and eastern Italy were among the spoils of the victors, the Piedmontese or Sardinian bulwark in north-west Italy, and the Netherland bulwark in Belgium and Holland, were not the rewards of allies, but the endowment of dependants, in the hope of favours to come.

The reunion of all the Low Countries (outside the French kingdom of the eighteenth century) under one sovereign, the head of the House of Orange, offered in some ways the hope of a more effective barrier against French movement than Spanish or 
Austrian Netherlands had done. For Holland was now vitally interested, as well as Britain, the two great Germanic powers, and perhaps Russia, in preserving this rampart. Not since the Pacification of Ghent, the crowning success of William the Silent ( 1576 ), had such a confederation bcen formed. It seemed to many to be full of promise. But it was not destined to last long (I8I5-I830). Racially, socially, economically, and in religion, the union was fatally defective.

The Swiss confederates, mainly Teutonic in race, might be trusted, with adequate European support, to form another breakwater in the middle east of the French frontier. And to these defences the 'Concert of Europe' added another on the south-east, by the restoration of Sardinia-Piedmont, under the House of Savoy, and by the addition of Genoa and the Genoese lands to its territories.

The Savoyard regions west of the main Alpine chain, ${ }^{1}$ which had been left to France by the earlier arrangements of $\mathrm{I} \mathrm{I} 4$, were now in $\mathrm{I} 8 \mathrm{I} 5$ once more joined to the North Italian state; the French borders were left, on this side, as they had been throughout the eighteenth century.

C. The principle of a Balance of Power, especially important in the eyes of British, Austrian, and French statesmen, was largely responsible for the admission of France to the Congress (in which Prince Talleyrand, 'the goat-foot,' subtlest and most sinister of diplomatists, played so important a part) ; for the destruction of the French Empire beyond the old borders of the French monarchy-the essential and primary act

1 With their centre at Chambéry. 


\section{NINETEENTH CENTURY EUROPE}

of reconstruction; for the restoration of the French state, without penal cessions, to those limits of the old monarchy; for the new system of the German Confederation which replaced the Holy Empire of former days; for the almost co-equal authority and practically co-equal power given to Austria and Prussia within that Confederation; for the deadlock which once more ensued within the Germanic world; for the constitutional experiment of the Kingdom of Poland ; for the Union of the Netherlands and the Union of Scandinavia; for the resettlement of Italy on eighteenth century lines.

D. Lastly, the Restoration of all things, as far as possible, to the conditions of I789-covering so many of the chief points aimed at under the Policy of Balance, as under that of Rewards and that of Precautionssecured the return of the Bourbon monarchy to France, with the pre-revolution territories, but with such modifications of the Ancien Régime as might (it was hoped) make the Restoration lasting. Louis XVIII. was to govern according to a constitution satisfactory to a moderate Liberalism, and not according to the system of Louis XIV. or Louis XV. Parliamentary partnership in government; an elected Lower House ; freedom of the press; religious liberty ; responsibility of Ministers to Parliament; judicial independence, were established.

The Restoration, here as elsewhere, was only partial: the modifications were often as noteworthy as the resuscitations; none the less a certain importance attaches to this policy of a return to ancient ways. 
Under the same system of rehabilitation, as we have seen, Italy was resettled, much as she had been in the days of Louis XVI., with a dominating Austrian influence; a restored Papal state; a restored South Italian Kingdom of Naples, or of the Two Sicilies, under the old dynasty; a restored and slightly strengthened Piedmont-Sardinia.

We have seen how far Austria and Prussia were now 'restored': the latter may be said to have returned, in reality, to a new and stronger European, a far stronger Germanic position; the former had for ever given up that German Imperial crown and station, which in the eighteenth century and even in the seventeenth had become the shadow of a name.

In the re-constitution of the Germanic body as a loose Federation, remarkably well answering in its weakness, its helplessness, its permanent condition of balance and deadlock, to the Holy Roman Empire of the German Nation in its last days, we have one of the best examples of the purely conservative work of Vienna.

Yet even here there were changes wide and deep.

Thirty-nine Germanic states composed the Bund of I8I5: they replaced the hundreds which had received final sanction at the Peace of Westphalia in I6 48 .

This wholesome simplification, due to the age of French ascendancy, was the work of the Revolution and its leader-but the reaction, the age of restoration, did not disdain this useful inheritance.

But all proposals to make this Confederacy an effective nation, as Prussia desired, broke helplessly upon the opposition, the anger, and the alarm of Austria and the 'Middle' States-Bavaria especially. 


\section{NINETEENTH CENTURY EUROPE}

No strong Central Government was yet to emerge, for a German people-as Stein ${ }^{1}$ and Blücher and Arndt and all the Nationalists had planned and hoped. Instead thereof, the old Austro-Prussian rivalry reappeared-the true double-headed eagle, presiding over a brood of lesser states, jealously watchful of their local independence, and themselves contributing not a little to the real headlessness of Germany.

The only bond of union was the new Federal Diet, or ambassadorial House of Lords, now set up at Frankfurt-on-the-Main, and composed of envoys from each of the Teutonic States-from some four, from some two, from others one, in all sixty-nine. The senior Austrian delegate was President; each state was pledged to make no alliance with a foreign power against the other members of the confederacy; each state at first undertook to grant a modicum at least of representative government to its subjects.

This permanent congress of diplomatic agents proved even more futile in practice than disappointed patriots had foretold in theory. Until Bismarck in I850 became the chief Prussian delegate in this Bundes-Tag, it scarcely played any part in history. And it collapsed in I866 (as part of the old German order destroyed by the great changes of that year), ' without so much as a dog barking.'

Except for the 'Austrian Netherlands,' now definitely severed from the Germanic world (to which only a part of these Low Countries had ever truly belonged), the new Germany of the Federation included just the

${ }^{1}$ Baron Stein, 1757-1831, one of the chief restorers of Prussia after Jena $[\mathbf{1 8 0 7 - 8 ]}$, the greatest Prussian or German statesman of this time. 
same territories as the old Germany of the Holy Empire, in its last days. Hungary, Schleswig, the Polish possessions of Austria and Prussia, Pomerania, the old Prussian ${ }^{1}$ lands, all lay outside the new, as they had lain outside the old Germany. Neither Austria nor Prussia were to bring into the Bund those lands of theirs which had not been within the Reich.

Holstein and Teutonic Luxemburg, though nominally inside the later, as inside the earlier realm, were now, as in the eighteenth century, practically foreign lands in the political sense.

Hanover, until the death of William IV. of England, was to some extent in a similar condition; only with the accession of Victoria was this connection broken, and the Germanic character of this region politically restored.

\section{ADDITIONAL NOTE ON CULTURE-HISTORY,}

$$
\text { I8I2-I } 5
$$

In the history of 'Culture,' these years (1812-15) are also memorable, although culture is still, as for many years before, overshadowed by politics.

(a) In Religion, the Revival of Christianity, and especially of the older Christianity (shewn in Napoleon's restoration of the French Church as early as I 801), makes further advances, with the help of 'Romanticism,' historic interest, and the reaction against the eighteenth century spirit. The Jesuits (partially suppressed since 1773) are revived in I8I4 by Pope Pius VII., together with the Inquisition and the Index Expurgatorius. A remarkable outburst of missionary activity in various Reformed Communions-in Britain, Germany, Switzerland and Holland-balances the new energy of Ultramontanism. The 'Evangelical movement' in England is

${ }^{1}$ 'In the strict sense, i.e. the provinces of 'East' and 'West' Prussia, east of Pomerania. 


\section{NINETEENTH CENTURY EUROPE}

now perhaps at the height of its power. Similar tendencies are noticeable in Russia (e.g. in Madame Krudener's influence over the Tsar, Alexander I.), but these are not deep or permanent.

(b) In Literature, Art and the 'Sciences of Man' there was much remarkable production. Scott's Waverley and Guy Mannering, the first of the greatest British series of historical romances, or romantic histories, appeared in $181_{4}-I_{5}$, followed by the two masterpieces, The Antiquary and Old Mortality, in I8r6. Jane Austen, after years of discouragement and neglect, was beginning to win attention with Pride and Prejudice in $\mathrm{I}^{8} \mathrm{I}_{3}$ and Mansfield Park in I8r4. (Emma and Northanger Abbey appeared just after the Peace of Vienna, I8I6-I8.) Wordsworth's Excursion, Shelley's Queen Mab, the first cantos of Byron's Childe Harold, are among the literary glories of the War of Liberation, I812-14. The Song of Beownlf was rediscovered, and published in I8I5. Grimm's Märchen or Fairy Tales, invaluable as a mine of folk-lore; Chamisso's Peter Schlemihl, the Shadowless Man; Béranger's early songs; and some of the best patriot poems of Arndt, Körner, and Uhland belong to these years. Southey's Life of Nelson, and Leake's Researches in Greece were perhaps the most outstanding contributions to orthodox history and to archaeology. In Philosophy, Hegel's Logic ; in Economics, Malthus' exposition of rent, were noteworthy.

(c) In Natural Science important researches were made in Light and Heat, as in Botany and Palaeontology. Cuvier's Rechorches, published in 1812 , were the true foundation of the last-named. Steamboat traffic steadily improves and becomes more venturesome (a little later, the first steamer crosses the Atlantic, New York to Liverpool, r818). 


\section{CHAPTER III}

THE EARLIER AGE OF PEACE, I8I5-I854

From the Settlement of Vienna to the Crimean War (I8r5-r854) Europe gave herself to the arts of peace. No military conflict of any importance occurred between the Christian nations of the Old World. The struggle for Greek Independence was a struggle against the Muhammadan enemy of Europe and Christendom. The history of our continent in these forty years is one of civilised progress Since the outbreak of the Protestant revolution there had scarcely been such a ' Truce of God.' Seldom had there been a more fruitful period of intellectual life, abounding in new developments of the most varied kind. And never in human history had there been such a time of advance in social and material well-being.

Throughout this time there is a certain political predominance of Russia upon the continent and a certain leadership of Austria in the Germanic world. While, of course, in the colonial, maritime and commercial spheres the supremacy of Britain is absolute, except for Russian Asia, 'Latin' America and the United States of the North.

The political history of these thirty-nine or forty years may perhaps be treated quite briefly. 
It is concerned chiefly with four main tendencies : First, the efforts of 'Reaction' or 'Conservatism' to dominate European Christendom, expressed in the Holy Alliance; in the attitude of the Russian Tsardom as guardian of law, order, legitimacy, and religion; in the diplomacy of Metternich; in the 'Catholic Revival'; and in so much else in the History of 'Culture':Second, the resurrection of political Liberalism from about I829-I830, expressed, for example, in the French 'July-Revolution' of 1830 ; in the Belgian and Polish risings of $1830-3 \mathrm{I}$, so largely resulting from the French explosion; in the British Reform movement; and in the almost general upheaval of 1848 :-Third, the progress of the Eastern Question, slowly moving towards the emancipation of the Christians of the Levant, expressed in Greek Independence; in the beginnings of a new Serbia ; in the continued advance of Russian, and decline of Turkish, power:-And last, the colonial development of the European races, expressed in the British conquest of India; the British settlement of Australia; the British and French advance in Africa; and the American developments.

Both the 'Eastern' and 'Colonial' questions spread over both the chronological divisions here suggested-before and after I829-I830. In both these matters the political element is inextricably bound up with religious, social, economic, and other questions.

\section{§ I. I8I5-30}

I. The overthrow of Napoleon was widely regarded as the defeat of revolutionary spirit, the victory of conservatism, property, legitimacy, and orthodoxy. 


\section{THE EARLIER AGE OF PEACE $5^{1}$}

More and more, after the Vienna Settlement, the spirit of Metternich and the Reaction rather than that of even the mildest Liberalism, tended to prevail. The Holy Alliance (to its ill-friends a 'piece of sublime mysticism and nonsense' 1 or an 'empty form of words' 2) which Tsar Alexander was so anxious to found upon Christian and monarchical principles, was in itself, perhaps, capable of various interpretations, but it gradually passed under the influence of ultra-Royalist, ultra-Conservative, and ultra-Orthodox exponents.

In his last years [18I8-25] the Russian Emperor, once so enthusiastic for liberty and enlightenment, became a disillusioned monarch, resentful and suspicious of the ungrateful people. 'You were right,' he said to Metternich ; 'I was wrong.' And on the sudden and mysterious death of Alexander in 1825, complete and resolute reaction stood forth in the person, reign, and work of his brother, Nicolas I., the inflexible and life-long champion of autocracy and orthodoxy [I825-55].

The restored French kingdom, which had begun under Louis XVIII. [I8I5-24], with the acceptance of constitutional forms and notions, so gratifying to Liberals everywhere, passed under the rule of Charles X. and the extreme Royalists in I824. The reaction towards the Old Régime, already in progress, now became triumphant, and official. In July, I830, the ' king of the priests,' 3 who preferred to chop wood (as he said) rather than reign like an English sovereign,

1 Castlereagh's comment. 2 Metternich.

3'There is no such thing as political experience,' moaned Wellington; 'with James II. before him, Charles X. is setting up a government by priests, through priests, for priests.' 


\section{NINETEENTH CENTURY EUROPE}

swept away the constitutional pretence by a series of ordinances which went far to re-establish the personal monarchy of the eighteenth century.

In Germany, liberal excesses (such as the Kotzebue murder) strengthened the hands of Metternich, and his spirit after I8I8 became ever more representative of the reigning princes and the governing classes. Austria remained rigidly autocratic ; Prussia abandoned the idea of the constitution which had been vaguely promised ; and practically all the other German states came into line before the end of r8rg. The decrees issued by the Congress of statesmen at Karlsbad in August, I8I9, and confirmed by the Act of Vienna in May, I820, shewed reaction triumphant, established a supervision of Universities and of the Press, declared the sacredness of the monarchical principle, founded a sort of political Inquisition into the underground workings of revolutionary spirit, and incidentally marked the highest point of Austrian influence in Central Europe in the nineteenth century. Men were astounded by the diplomatic weakness of Prussia, which seemed to sacrifice weighty political advantage for the sake of a visionary German 'brotherhood.'

Meantime Austria and the Reaction went on, as it seemed, from strength to strength. In Southern Italy, as in Piedmont, Liberalism was crushed by Austrian intervention in I82I, while in Spain it was suppressed by French arms in I823. In both the Peninsulas a strict type of the Ancien Régime was restored. The Congresses of Troppau, Laibach, and Verona (I82022) expressed the approval and authorization of 'Europe,' if not altogether of England. 
The Greek rising (I82I-29) formed perhaps the chief exception in European politics to the general political tendencies of this time. And here the position was difficult and complicated. Tsar Nicolas was no friend of ' rebellion,' but he was the supreme champion of Eastern Christianity and of the subject Christians of the Levant, and he could net bear tamely to witness the extermination of the miserable Greeks, to whom in a sense Russia owed both orthodoxy and autocracy. British policy was still guided by very Conservative councils, but the situation in Hellas was so representative of Oriental oppression at its worst that even British statesmen faltered in their defence of Turkish rectitude. Almost every lover of culture throughout Europe was moved to tears, to prayers, to action. When at last, with Egyptian help, Sultan Mahmud (from I825) seemed in the way to make an end of the Hellenes altogether, and to achieve a true Ottoman peace by creating a desert, Russia and Britain, with France as an ally, protested and intervened. And in the Bay of Navarino, the Pylos of ancient history, where Athenians had worsted Spartans so many years before, naval squadrons of the three Christian powers destroyed the Turkish-Egyptian fleet [Oct. 20, I827].

Horrified by this impiety, and eager to disclaim it, in Wellington's language, as an 'untoward event,' even the English Tories could not undo what had been done. And Russian action completed the deliverance. By a daring plunge Marshal Dyebich crossed the Danubian Principalities, the Danube itself, Northern Bulgaria, and the main Balkan range (whence his new title, Zabalkanski), and so entered Adrianople Here he was within roo miles of the Bosphorus and the 


\section{4 \\ NINETEENTH CENTURY EUROPE}

capital. Meantime, in Asia, Marshal Paskyevich, Russia's other outstanding 'war-lord,' the victor in the Persian campaign of 1827 (whence his princely name of Erivanski) had won Kars and Erzrum, and broken through the Turkish frontier defences. The Porte was panic-stricken, and the Tsardom shewed a wise moderation. Peace therefore was speedily concluded on the basis of the Independence of Greece, and the cession to Russia of such parts of the Caucasus shore-line as were still nominally under the Sultan's obedience,-from the 'Cimmerian Bosphorus'1 to beyond Poti and almost to Batum.

By this Peace of Adrianople Russia maintained and extended her prestige and power 'at the head of European and Christian civilization.' But the Tsardom, daily more and more closely identified, under Nicolas, with a rigid conservatism, a narrow military spirit, and an unbending orthodoxy, was not fully alive to the new perils which menaced it, nor conscious of the best means of self-defence.

Almost unnoticed, at the other end of 'Turkey in Europe,' a small parallel development had begun before the Greek insurrection, and had slowly matured during the Greek struggle.

The faint commencement of Serbian independence lay in the small and almost worthless measure of Home Rule conceded by the Turks in I8r7. Although Turkish garrisons remained, the Serbian people slowly moved towards complete autonomy. Their position was somewhat improved by the Treaty of Adrianople, which secured the freedom of Greece. But not till

2 The entrance to the Azov. 


\section{THE EARLIER AGE OF PEACE 55}

long after the Crimean War was Europe conscious of a Serb nation and its claims, ultimately so disruptive, in the decrees of fate, to the peace of all Europe and Christendom.

\section{§ 2. $\mathrm{I} 830-\mathrm{I} 848(\mathrm{I} 850)$}

The emancipation of Greece, though a marked triumph for Liberal ideals, as we have seen, was anomalous rather than typical-at a time which in so many ways marked the flood-tide of reaction. Nicolas of Russia, who is the chief deliverer of Greece, is elsewhere the incarnation of autocracy, orthodoxy, and the reaction. The 'Catholic Emancipation' effected in Ireland, as in Britain, by the Catholic Relief Act of April, I829, was a far more definite indication of a new Liberal wave in one of the leading countries of Europe, one which had long been the special home of a certain measure of free spirit, but which, in its terror of the Revolution, had for thirty years given itself over to very different tendencies. Here was a first breach in the defences of the great citadel of the English aristocracy; a first concession of the new age in the island empire to Liberalism, Democracy, and Nationalism; a first relaxation of the Conservative safeguards in Church and State. The Duke of Wellington himself, leader and hero of that very Conservatism, allowed, accepted, and commanded it. It was incredible, almost a blasphemy, to the bulk of his followers; but the Duke ordered, and his men retreated. Daniel O'Connell led his 'wild Irish,' politically excommunicate since the days of William III., to enfranchisement, and to the 


\section{NINETEENTH CENTURY EUROPE}

beginnings of national revival. It was the initial success of Hibernian Home Rule. Within a few years, O'Connell was able to develop a formidable agitation for the definite Repeal of the Union.

Next came a striking Liberal success in the very centre of the European stage. In I830 the restored French monarchy was overthrown; Charles X., attempting to set up his 'government by priests,' was expelled in the 'July-Revolution ' $;^{1}$ a Liberal and Constitutional King took his place in Louis Philippe, ${ }^{2}$ a Prince of the Blood, and Duke of Orleans, but also a hero of the early Revolutionary war, especially in the vital year I792. Autocracy and clericalism received a severe blow: the Reaction was clearly shaken.

But for the well-grounded fear of European intervention, France might have returned to Republican government and Republican life; the prudent expedient of 'Citizen-Kingship' averted the danger, while it especially conciliated British Liberalism by the sincerest form of flattery. Nothing could have been more satisfactory to the spirit of moderate reform than the régime of the new 'People's King.'

The July-Revolution in France had considerable results in other countries of Europe-mainly along Liberal and Nationalist lines. For one thing, Roman Catholics of the southern or 'Belgian' Netherlands, with strong support from the France of Louis Philippe, rose in revolt against the maternal, or grand-maternal, arrangements of Vienna in their
2 27th to 3 oth July, 1830 .
: Reigned 1830-1848. 
behalf, and threw off the rule of Protestant Holland. The efforts of the House of Orange to retain the sovereignty of all the Low Countries were feeble and ineffective, and the intervention of the Great Powers practically sanctioned the new state. Thus for the first time a Belgian nation, a self-subsisting Belgium, came into existence, composed in pretty even proportions of Teutonic Flemings (in west and north) and Romance Walloons (in south and east), whose chief bond of union-if we except their sturdy independence of character and love of liberty-was their spiritual allegiance to Rome.

In I $_{7} 8-85$ the Southern Netherlands had been completely and continuously severed from the Northern -until the Vienna statesmen in I8I4-I5 tried to revive the work of William the Silent and the times of the Pacification of Ghent. Although never forming hitherto a separate and independent nationality, although always a part of some other state-system, Spanish, Austrian, or French, they had become absolutely habituated to separate Netherland life, and quite ready to face the open sea of independent political adventure.

The Brussels rising of August 25, I830, beginning in a theatre-demonstration, had developed by the middle of October into a Belgian insurrection. Except for the fortress of Antwerp, the whole country had thrown aff Dutch rule. On November I8 the Belgian Declaration of Independence was issued-Independence under a 'Constitutional and Representative Monarchy.'

Meantime a Conference of the Great PowersBritain, France, Austria, Prussia and Russia-meeting 
in London in early November, I830, brought about a sort of truce between Dutch and Belgians, and recognized the new State of the Southern Netherlands, under the Provisional Revolutionary Government, ${ }^{1}$ which soon realised its ideal of constitutional monarchy. In April, I83I, Prince Leopold of Saxe-Coburg, the uncle and life-long friend and adviser of Queen Victoria, accepted the offer of the Belgian Crown. And on Nov. I5, I83I, the Treaty of London between the Great Powers and the new Kingdom regulated the position.

'A kind of war' with Holland dragged on till I833, and peace was not formally signed till I839. Belgium now became a neutral state, under the guarantee of Britain, France, Russia, Austria, and Prussiathis was the famous 'scrap of paper.' To defeat a renewal of Dutch invasion, and to wrench the fortress of Antwerp from Dutch hands, a French army had entered the Netherlands, and completed the 'emancipation of Belgium.'

But all French attempts to make profit out of the Netherland revolution - unquestionably carried through largely with French aid and by French examplefailed before the stubborn and jealous resistance of other Powers.

'We... have no security for Europe,' declared Palmerston, 'but by a strict observance of treaties and an abnegation of ... aggrandisement. The moment we give France a cabbage-garden or a vineyard, we lose our vantage-ground of principle. The French must go out of Belgium, or we have a general war, and a war within a given number of days.'

1 Formally established in December 1830. 
France had saved Belgium, but for her reward, except for the dismantling of some border fortresses, she was left to her own conscience. For this exalted ethical result, so barren in comfort to national feeling, Louis Philippe paid dearly.

Sporadic risings in Germany and Italy also followed upon the July-Revolution of Paris, but they were unimportant and transitory, and apart from Belgium it was only in Poland that men witnessed a real upheaval. But with what different results! Nicolas of Russia was another kind of antagonist from William of Holland. Beginning as a Warsaw night-rising on Nov. 29, I830 (just when the Belgian revolution had completed its early triumph), the Polish insurrec'tion proclaimed before Christmas a national revolt of the Polish people against the Russian connection (Dec. I8), and in the New Year declared the Independence of Poland (Jan. 25, I83I).

But the foreign aid so confidently expected was exhausted in the diplomatic notes and 'good offices' of Britain, France, and Austria; and though for a time aided by terrible outbreaks of cholera in the Russian armies, and by risings in Lithuania and the Ukraine, the Polish insurgents were crushed by the opening of September I83I, after a struggle of nine months. From first to last the bulk of the Polish peasantry (among the most oppressed in Europe) remained indifferent and aloof, and the revolt (as in 1863) was carried on by landowners, clergy, and townsfolk. From first to last, as in the eighteenth century and in 1863 , aristocratic misrule and internal discord were the bane of the Polish cause. By their treason 
(in the Russian view) the rebels had forfeited the privileges of their country. The Congress-Kingdom of Poland, which the Vienna statesmen had devised with such care, and whose constitution had galled Nicolas so often, was now swept away. No longer a 'limited' king on the Vistula, the Tsar now made himself autocrat and emperor in Warsaw as in St. Petersburg. The frontier between ' Poland ' and 'Russia ' was abolished. An Ukas of 1847 completed the change legally begun by the Organic Institution of February 26, 1832, which declared the former 'kingdom' a province of the Russian Empire.

As a measure which chiefly concerned Ireland, Roman Catholic Emancipation, however deep its significance, and however vital its consequences, stirred the English people far less than the Parliamentary Reform which after nearly fifty years of failure and discredit was at last effected in I832. By this act the British aristocracy and gentry practically admitted the middle classes (as in 1867 and in 1884 the lower classes) to a share of political power. The effects of the Industrial Revolution were in a measure recognized. The new towns created by the new industries and the new trade-Manchester, Liverpool, Birmingham, Leeds, Sheffield, Bradford, and the rest -were given a not ungenerous representation in Parliament.

Fifty-six 'rotten boroughs,' or 'pocket-boroughs' - places without any adequate body of citizens, sometimes (like Old Sarum) practically without inhabitants-whose members had long been the simple nominees of the great families, were disfranchized. 


\section{THE EARLIER AGE OF PEACE 6I}

As a result, the new House of Commons shewed an immense Whig majority-the Tory party in the Lower House sank, for the moment, to a fraction.

Soon Irish Nationalism began seriously and threateningly to demand a measure of self-government, the modification of Pitt's Act of Union of I800, a separate Parliament for Ireland. But the growth of this agitation was checked for many a day by the famine of I846; by the vast emigration which followed; by the death of the 'Liberator,' Daniel O'Connell, in I847.

A fresh and great Liberal success marked the close of this time: in $1845-6$ Protection was undermined and Free Trade enthroned by the abolition or diminution of many duties on imports, by the removal of all duties on exports, and especially by the Repeal of the Corn Laws and the extinction of the taxes on grain.

In I848 Europe arrived again at a time of revolution-volcanic, but brief. Not since the fall of Napoleon had she felt such unrest. The ultimate causes of the upheaval, no doubt, lay in the working of the great political and social forces of the time, nationalism and democracy, both conscious of tremendous but repressed energies; both dissatisfied with existing conditions; both ready and eager, after many years of quiet, to make and to mar, to pull down, to build, and to plant. But the immediate and active reasons are unquestionably to be found in the ambition, the ennui, and the discontent of the French people after thirty years (more or less) of bourgeois monarchy; in the re-awakening of Napoleonic 
ideas and ideals; and in the disappearance of the Allied control, still so powerful in I830.

Louis Philippe, excellent man, brave and brilliant soldier of the great Jacobin days, had done not a little for France as Citizen-King. He had given her safety and order; he had raised her prestige, and extended her new Colonial Empire. Aided by time, he had freed the country from the stigma of the black sheep in Europe's pen, the one danger against which all other states combined and guarded. An Entente with Britain had been founded afresh. But even as these things were being more and more secured, national Chauvinism woke to fresh and dangerous life. The bourgeois régime was judged by Napoleonic and seventeenthcentury standards, and Louis Philippe fell because France was both piqued and bored. ${ }^{1}$

A franchise question (like that of 1867 or 1884 in England) furnished the excuse. The middle class, on whom the Government rested, steadily refused to take the lower orders into partnership; all further extension of the parliamentary vote was stubbornly resisted.

A Reform demonstration was prohibited at the opening of 1848. Rioting broke out on February 22, and soon all Paris was astir. The troops in the capital sided, actively or passively, with the rioters, and within three days the King abdicated in favour of his grandson. But Republican elements, impotent in

${ }^{1}$ French experiments with spirited foreign policy in Italy, in the Eastern Question (especially as to Mehemet Ali of Egypt), in the colonial field, and elsewhere, had not been brilliantly successful (except in Algeria), usually arousing the suspicion and opposition of British Governments. 
I830, were dominant in this revolution, and the Second French Republic was now proclaimed, with universal manhood suffrage.

But divisions immediately declared themselves: the extreme or Socialist wing could not work with the Moderates ; the 'national workshops,' established to placate the former, strengthened the latter by their futility; and the Parliament, elected on the new suffrage, proved emphatically Moderate. The national workshops were closed in June; and the rising of the Socialist populace was rigorously and mercilessly crushed by General Cavaignac, acting as Dictator. The Constitution of the Republic was then settled: there was to be one Chamber, a House of Representatives, chosen by unrestricted manhood suffrage, and a President, with the power of appointing the Ministers of State. President and Parliament alike were to be chosen for four years.

In the elections held in December, I848, Louis Napoleon Bonaparte, a nephew of the great Napoleon, who had spent his life in reviving the Napoleonic idea, and in conspiring against rival forms of government in France, was elected President by a vast majority. Five millions of votes were cast for him, less than two millions for his chief rival, General Cavaignac.

Since the outbreak of the revolution in February, this clever adventurer, so long unfortunate, and destined at the close of life to experience again the fiercest buffetings of fate, had been lucky and adroit. And so things continued for some time. Everything seemed to play into his hands. The composition of the new Parliament, in which no party dominated, favoured his ambitions. His own policy was, for a time, 


\section{NINETEENTH CENTURY EUROPE}

admirably well-judged. Especially did he win and deserve applause, as a leader of material progress. The improvements he effected, suggested, or patronized, in agriculture and town-planning, in manufactures and industries, in 'ways and communications,' in the welfare of the army, and the comfort of the labouring classes, were undeniable and striking. His skilful appeal in 1848 had won him a great electoral victory. His Presidency won him for a time the heart of France. But not of the Parliament, by whose mistakes he had profited. As his term of office drew towards its close, the Chamber plainly showed itself hostile to a renewal. Louis Napoleon, therefore, with the effective and unscrupulous aid of St. Arnaud, his Minister of War, Maupas, his Chief of Police, and other favourers of an Imperial Restoration, cut the knot of his difficulties by the Coup d'Etat of December I-2, 185I. During that night, troops occupied the Chamber and all the strategic points throughout Paris which the conspirators wished to garrison. Many of the leading opponents of the President, especially in Parliament and the army, were arrested in their houses, often in their beds. The Government compositors were forced to print manifestos which greeted the good Parisians with the first light of December 2, announcing from every convenient wall what had happened, as the President wished it to be understood. The Chamber of Deputies, according to these affiches, having become a focus of conspiracy against the well-being of France, the President had made himself, for the moment, Dictator, to save the country. A new Constitution, based on manhood suffrage, would immediately be issued. 
Capital and provinces alike seemed, for the moment, stunned, acquiescent, or gratified. And when on December 4 insurrections began, with fierce rioting in Paris, the President and his friends were well prepared. ${ }^{1}$

Plenty of military force was at command, and it was vigorously and unsparingly used. Socialist cruelties, a 'Red Terror,' ir certain places, helped to excuse and justify to many the 'White Terror' of the new Dictator. Army and Church were, on the whole, enthusiastic for the President. And before the end of I85I a plébiscite seemed to shew the nation hardly less enthusiastic. By more than ten to one Napoleon was confirmed in his Dictatorship, and given power to issue a new constitution.

By these events a new Napoleonic era, and empire, had been effectively begun, but the nephew waited a year from his Coup d'Etat before following his uncle to the full Imperial dignity, and claims. Then a new plébiscite, with equal unanimity, authorized him to reign as Emperor of the French (December 2, I852). With dynastic punctilio, he took the title of Napoleon III.

Thus in a new autocracy-where the sovereign appointed all ministers of State and all important officials, initiated all legislation, commanded all the forces of defence, declared peace and war, nominated the Senate, and limited the powers of the Deputies to a mere acceptance or rejection of measures, and to the discussion, without control, of public affairs-had ended the revolution of $\mathrm{r} 848$, in its head-centre and source, the land and people of France.

Similar were the results of the great year of revolution elsewhere.

I ' Provoke an émeute while you have strength to suppress it.' N.C.E. 


\section{NINETEENTH CENTURY EUROPE}

If in France the revolutionary earthquake had finally produced, to all appearance, a stable and popular autocracy-in the Germanic world and its dependencies, torn in all directions by similar movements, the immediate issue was usually a simple or partial return, after a cycle of bewildering change, to the old order. When the convulsion had subsided, everywhere in Central Europe reappeared the landscape of the Vienna Settlement-although the chief farmer had disappeared, and some fields were better cultivated.

From Vienna to Berlin, from Hanover to Munich, peoples rose, thrones tottered, constitutions were demanded, rights were granted. Metternich, so often the incarnation of the reaction on its baser side, was driven from the Imperial city, his house burnt; the Austrian Emperor himself fled to Innsbruck, in Tyrol ; the Chekhs of Bohemia, the Magyars of Hungary, broke out in revolt. In Berlin the Prussian King, the gentle, delicate, emotional Frederick William IV., accepting for a moment the popular demands, sent the troops out of the city, and stood with uncovered head on the balcony of his palace to honour the funeral march of the victims of a night of riots and barricades. To gratify other elements of the insurrection, he rode through the streets of his capital wearing the black, red, and gold colours of German Nationalism. Henceforth, he proclaimed, Prussia was absorbed in Germany.

A new Prussian Parliament was called. In this first came upon the stage of public life Otto von Bismarck, the stern unbending Conservative- ' only to be used where the bayonet governs unrestricted.' 1

${ }^{1}$ So Frederick William wrote against an early mention of his name in a State Paper. 


\section{THE EARLIER AGE OF PEACE}

In Frankfurt-on-the-Main, in St. Paul's Churchthe famous Pauluskirke-there gathered a German National Assembly, the first in history elected by universal manhood suffrage (May I5). The old Diet accepted it ; a new constitution for the whole Germanic world issued from it-'a transcript of Magna Carta, on Continental blotting-paper'-to the best of its power, it revived the old Imperial Crown. To the King of Prussia, after much discussion, it offered the diadem of the Holy Roman Empire of the German Nation (March 1849). But Frederick William absolutely refused. He had soon repented of his ' surrender to the agitators' at Berlin. He was not uninfluenced by the failure of the revolution in German Austria, where by October 1848 the Imperial Government had triumphed. He re-occupied the capital with troops; he dissolved the Prussian Parliament; and although he summoned another, and granted a new constitution, he retained control of the executive-ministerial responsibility was still to the crown. He would walk in the steps of the German Nationalists no longer. For not only did his innate Conservatism revolt against the acceptance of an Imperial bribe from ' the Revolution,' but it kept him true to his old, suicidal policy of Austrian alliance, and made him shrink with horror from that Austrian war by which alone he could secure the Imperial offer of the Frankfurt Parliament. After all, Prussia was not yet to lead Germany, nor to be absorbed in Germany.

The 'great refusal' of the Hohenzollern waverer finally wrecked the storm-tossed ship of German Nationalism at this time. Frederick William had rejected the offer of the Kaiserwirrde. All the remains 
of vitality straightway went out of the poor body of the Frankfurt Parliament. The Deputies dispersed. Except for the overthrow of Metternich and the weakening of his system, and for a certain strengthening of 'representative institutions' in Prussia, everything in German politics had returned, or was returning, by the Easter of 1849 , to the old conditions of the 'Great Peace' (I8I5-48).

Within the lands of the Austrian Empire only Hungary still ' resisted authority,' for only in Hungary was the revolution backed by a sufficient force of militant nationalism.

In Bohemia a man of energy, Prince Windischgrätz, the military governor of Prague, left to his own resources by the terrified and feckless Imperial Government of the moment, had acted for himself, and crushed both Democratic and Slavonic (or Nationalist) insurgents in the midsummer days of $1848 .^{1}$ In Croatia another 'saviour of society,' Count Joseph Jellachich, succeeded in rallying the South Slavs in support of the Hapsburg cause against the Magyars and the German Liberals; while in Austrian Italy, the ill-combined forces of Liberalism and Nationalism suffered a decisive reverse at the hands of General Radetzky and the loyalist troops. The Piedmontese invasion was utterly defeated at Custozza on July 25. Acting vigorously together, Windischgrätz and Jellachich, though unsuccessful in their first attacks upon Hungary, now suppressed the revolution in Vienna itself (October 1848). The weak old Emperor, whose feebleness had so much increased the difficulties of the Government, was brought to abdicate. His young nephew, Francis

2 June 12-17. 
Joseph, took up the task of Hapsburg chieftainship at eighteen years of age-an old head on youthful shoulders. He was to be the last great sovereign of his house, the last Austrian 'president' in Germany, the last Hapsburg ruler in Italy, the longest holder of supreme power in the Christendom of recent time (I848-I9I7).

Under his name, not unaided by his sagacity and resolution, the Reaction speedily gained ground in Austrian Europe. Piedmont-Sardinia, breaking loose again in the cause of Italian freedom, was finally repulsed at Novara (March I849); and the Magyar danger, which seemed to grow more acute in the spring of I849, was at last averted, in spite of the shameful defeats of Austrian armies, by the Magyar errors of policy, by the diplomacy of Vienna, and by Russian alliance.

Louis Kossuth, after months of brilliant leadership, encouraged by marvellous military success, by the sullen discontent of Italy, and by fresh hopes of Slavonic defection from the Hapsburg cause, if not of Slavonic alliance with his own, proclaimed the deposition of the Austrian Emperor, and in his place a Republic of Hungary, with himself as Governor (March I849).

It was probably a fundamental mistake. For such a declaration not only brought Russia into the field against him, but introduced suspicion and discord into the Magyar camp. The same Conservative feeling which now led the Tsar to declare war against Republicanism on his frontiers, alienated from the new Republic much of the powerful Conservative element within her borders. In any case, Russian military intervention 


\section{0 \\ NINETEENTH CENTURY EUROPE}

was decisive. By August the war was over, and Hungary conquered. Asking no reward, the Tsar withdrew his troops, satisfied to have placed this seedplot of revolution once more under the fostering care of his brother autocrat, and confident in the lasting gratitude of a Government and a Dynasty which were so soon to betray his trust. In the same spirit, a year later, Russian diplomacy interfered to stop a Schleswig-Holstein crisis which might have ended the German deadlock, and ultimately given preponderance to Prussia and nationhood to Germany. With Russian help Austria was able, for the moment, to baffle her chief German rival in the Convention oi Olmütz, truly 'a Prussian humiliation' but also 'an Austrian weakness' (r850). With Russian help Austria hoped to make herself effectively mistress of Germany, after Olmütz. And although the diplomacy of Nicolas tardily realized the danger of this, and procured the continuance of the old Bund, the old balance, and the old deadlock, in Germany (I85I), yet it was not often that one monarch had rendered to another such services as the Tsar had rendered to Franz Josef. Like John Sobieski, he had saved Vienna (he said afterwards), and shown himself a fool. 'C'est l'autre imbécile qui a sauvé Vienne.'

\section{ADDITIONAL NOTE ON CULTURE HISTORY,}

$$
\text { I 829-3I }
$$

The record of European culture has now become, and remains till the Crimean War, far more important than that of political change :

(a) In Religion (apart from such great 'political ' events as Catholic Emancipation in Britain and Ireland by law, the 


\section{THE EARLIER AGE OF PEACE 7 I}

Emancipation of the Christians of Greece by war, and the partial disestablishment of the Church in France by the new Citizen Monarchy of I830), we have from the German, Karl Lachmann, in 1831 , the first true critical edition of the New Testament in Greek. In the Church of England things are moving towards the start of the new High Church, or Tractarian, movement, which definitely appears in 1833 .

(b) In Literature and the 'Humanities,' Victor Hugo's early work is followed in I83I by his masterpiece, Notre Dame de Paris. At the same time Pushkin in Russia is producing some of his best-known work (e.g. Eugen Onyegin).

In History, J. F. Böhmer's edition of the Regesta of the Mediaeval or Holy Roman Emperors marked a decided step forward. In Philosophy one supreme leader passes, to be replaced by another; Hegel dies (I83I), Auguste Comte begins to issue the Philosophie positive (1830).

In $A r t$ there is not only important French production in painting and sculpture, but the erection of the Walhalla, near Regensburg, on the Danube, by the King of Bavariaa significant monument of the new German Nationalism. At the same time, Chopin is rising to the height of his fame.

(c) In Natural Science and Social Progress, Lyell in Geology, Cuvier in Natural History, Faraday in Magnetism, with others, do remarkable work at this time. The British Association for the Advancement of Science is founded in $\mathrm{r} 83 \mathrm{I}$.

In 1829 the first great railway for passenger traffic is opened -between Liverpool and Manchester-the work of George Stephenson, whose engine travels at 35 miles an hour.

In Exploration, the brothers Lander trace the lower course of the river Niger, and in the same year the British African Association is expanded into the Royal Geographical Society (I830).

Thomas Arnold's appointment as Head of Rugby marks a new start in Education, both in and out of England (1829).

In Bohemia the revival of the Slavonic language among the Slavs of middle and upper classes begins about this time. From the first it has a definite anti-German, anti-Austrian, trend, and is highly political in spirit. The historian Palacki inspires it. 


\section{ADDITIONAL NOTE ON CULTURE HISTORY, I $848-50$}

(a) In Religion there was a marked revival of the prosperity of Catholicism in France, as the Napoleonic revival became consolidated. In England the new High Church movement had run through its 'Tractarian' or 'Newmanite' chapter, by 1845 , and had apparently fallen upon evil times. Critical ideas in Theology had made great progress in Germany. Ferd. Christian Baur's leading work is of 1846 ; Tischendorf's edition of the Greek New Testament, by far the best as yet, appeared in $\mathbf{I} 849$.

(b) In Literature, Art, and the 'Human Sciences' these years give us Thackeray's Vanity Fair (1848); Ruskin's Seven Lamps of Architecture (I849); Matthew Arnold's Early Poems (1848); the formation of the pre-Raphaelite brotherhood by D. G. Rossetti, Millais, Holman Hunt, and others (1848); also Macaulay's History of England (mainly from r685), that ' great Whig manifesto and apology,' but noteworthy for its deep and careful research (1848, etc.); John M. Kemble's Saxons in England, the first good modern critical survey of Old English civilization before the Norman Conquest (r849); and Dennis' Cities and Cemeteries of Etruria (1848). In Economics, John Stuart Mill's Political Economy was published in $\mathrm{r} 848$.

In Natural Science and Social Progress there is much valuable study of Electricity, of Light and Heat, and of Gas; the Menai Straits tubular bridge is constructed by Stephenson the younger ; formal slavery is abolished in the French Coloniesanother concession of High Politics to the new philanthropy. In Exploration, the German missionaries, Krapf and Rebmann, begin the discovery of the Central African 'Alps' (Kilimanjaro, etc.). 


\section{CHAPTER IV}

THE CRIMEAN WAR, THE EASTERN QUESTION AND THE TREATY OF PARIS

ForTy years of rest and stability, as things goforty years of peaceful progress almost beyond parallel - had been secured to Europe by the Vienna Settlement. Then, in the middle age of the century, we have again a time of open and violent political struggle, of great and obvious territorial change, of fundamental alteration in the Balance of Power (I854-78). The Europe re-formed by these events is the Europe we all know, the old civilized world upon which broke the world-war of rgr4. The conditions inherited by us spring from the conflicts, the policies, and the movements of the age of Bismarck. The first act in this reconstruction, the unintended preface to the new victories of Nationalism, the true beginning of the Bismarckian age, is the Crimean War.

'There was repose in the empire of the Sultan, and even the rival churches of Jerusalem were suffering each other to rest, when the French President, in cold blood, and under no new motive for action, took up the forgotten cause of the Latin church of 


\section{NINETEENTH CENTURY EUROPE}

Jerusalem, and began to apply it as a wedge for sundering the peace of the world.' 1 No lover of Russia wrote this, but a lover of truth, the historian of the Irvasion of the Crimea.

The Capitulations of I740 (in the days of Walpole) gave France the right of protecting the Latin Christians in Turkey, and of controlling certain holy places, and things, in Jerusalem. On the basis of the KuchukKainarji treaty of I774-the famous peace, on the eve of American Independence, which closed Catherine II.'s earlier triumphs over Turkey-Russia gradually erected a parallel claim to a kind of guardianship, mainly spiritual, of all the Greek Orthodox under Ottoman rule, and to a special political protection of the Christian peoples of Moldavia and Wallachia. These 'Danubian Principalities' represented the only Turkish lands, and subjects, now left on the north of the Danube.

During the Revolutionary age, France, atheist or semi-atheist for a time, had cared for none of these things. But since the Great Napoleon had restored the Gallican Church, the French nation had slowly moved back towards its old position in these matters. Napoleon 'the Little' had floated into power on the crest of a wave of Catholic feeling, hastening with other waves towards that strange land of reaction and progress which we call the Second Empire. To Catholic support, in large measure, the Man of Destiny owed his position. To Catholic claims it was his duty, his policy, and often his pleasure, to give his sanction. And in Syrian matters, he conceived, he had other good reasons for intervention. So, in the spring of 1850, when preparations were being made for the

1 Kinglake, Crimea, i. 46 (ed. of 1890). 
opening of that temple of universal peace, the International Exhibition in Hyde Park in London, ${ }^{1}$ a new age of discord was opened by the action of the French Ambassador at Constantinople.

In the name of the French Republic, and under orders from the Prince-President, he now demanded the restoration to the Latins of all their property and rights in Jerusalem.

Russia was in no mood, and apparently under no necessity, to yield anything. The compromise offered by Turkey in March, 1852 , failed to satisfy, and in the earliest spring of 1853 Nicolas, losing patience, attempted to force the issue. Three years had come and gone since the controversy was opened; the London Exhibition had been held; the whole world had been assured of the inauguration of an era of pacific brotherhood; but it was the close of such an era, rather than the commencement, that it really signified.

Forty years of peace seemed an eternity, and as an eternity it was continued in the dreams of an unthinking world The pleasant summer days-men seemed to fancy-would last for ever. But the elements of tempest were gathering in the heat, and the material of a vast international conflict, the first in a series of struggles which again transformed the Continent, was now ready.

When Louis Napoleon had opened the controversy he was far from an absolute ruler, but in December

1 This (1850-1) was a time of remarkable civilized achievement in many fields - of the first submarine telegraph (Dover to Calais), of the beginnings of Manchester University, of Ruskin's Stones of Venice, of 'Tennyson's In Memoriam, of Dickens' David Copperfield, of Hawthorne's Scarlet Letter, of Solovev's Russian History, of Ibsen's first play. 
of $185 \mathrm{I}$ the President, nearing the end of his short term, had turned himself into a practical monarch by the Coup d'Etat. A year later the Second Empire had been fully and formally created. And although the new ruler, the Elu de sept Millions, had declared that the Empire meant Peace, 'L'Empire c'est la Paix,' the true position of the brilliant, unstable adventurer was far more truly sketched in the gossip of King Leopold of Belgium to Queen Victoria. 'The dangers of the position are great; I shall certainly be a mark for assassins. Even now serious plots are forming in the army. I am on my guard to prevent such explosions ; my means may be war.' 1 In some such words Louis Napoleon was said to have warned Eugénie de Montijo of the risks attending the elevation to which he had just raised her.

From various points of view a Russian war could and did attract the new Emperor of the French. It would be, on the whole, decidedly popular throughout Europe, and not least in France, though it was in Britain that the current Russophobia was fiercest. It would also, if successful, avenge the retreat from Moscow, and solace the pride of France. Again, it would-always assuming success-put Napoleon's throne and dynasty on a firmer basis. It might give France once more something like a premier position on the mainland of Europe- ' Queen of the Continent.' And it would wipe out the affronts which Nicolas, in his doctrinaire hatred of the Revolution, in 'the dotage of his Francophobia,' had offered. Russian blood and Russian defeat would atone for

2 'Le moyen sera peut-être la guerre.' 
discourteous modes of address, ${ }^{1}$ as for unfriendly methods of policy. Of the value of Russian alliance for France, neither the new Emperor nor his people had any just conception.

In Britain, hatred of Russia had become a national obsession. The cordial friendship of earlier days, rarely more cordial than in the days of Moscow, Leipzig, and Waterloo, was no more. Nothing seemed too monstrous to be written, nothing too grotesque to be believed, about the new and hideous bogey which had taken the place of the French red spectre.

'To hate a Frenchman as one hates the devil ' had been an axiom in 1793 or I8I3. Now, in I853, 'in crippling Russia we fight the battle of mankind ' ... for ... ' every Russian is inspired with the conviction that his country is one day to conquer the world.' 2 The interference of Nicolas with Hungarian freedom, his overthrow of the Magyar revolt in the very moment of its success, had filled up the measure of his iniquities in the eyes of Liberal Europe, and especially of Liberal Britain. The Conservatives had equally made up their minds, and joined with the Liberalism they hated, to denounce the great enemy of the British Empire. With surprising unanimity, therefore, though from the most different motives, British opinion was now inexorably arrayed against Russia-willing and eager to surrender itself to any anti-Russian movement. Austria, saved from disruption by Russian armies

1 Nicolas at first refused to admit Louis Napoleon into the brotherhood of European sovereigns, and steadily addressed him as 'Ami' instead of ' Frère.'

2 These expressions of Mr. Roebuck's and Lord Clarendon's are quite unconnected in their original delivery-but naturally supplement one another. 
in the Hungarian crisis of 1849 , supported against the Prussian danger by Russian diplomacy in the Olmütz crisis of 1850 , was far too suspicious, cold-blooded, and mean-spirited to dream of sacrificing one scrap of interest for gratitude. She judged according to the appearance, and had her reward.

In Italy, Sardinia-Piedmont, the only living power in the Peninsula, was perfectly ready, under Cavour's leadership, to attack the unpopular monster of the East, if thus she could promote her aims. Certain it was that the Russia of the Tsars would never assist an Italian unity only to be attained by the expulsion of ancient dynasties, by methods savouring of revolution; while Louis Napoleon was prepared to reward support against the Russian tyrant by answering support against the Austrian oppressor.

Prussia alone, among European states of consequence, despite the Russian attitude at Olmütz, ${ }^{1}$ remained a genuine friend to the power which had so often stood by her. A Bismarckian policy more fully realized, Bismarckian suggestions accepted without reserve, might have produced in I854 a complete Russo-Prussian alliance. But ' not for me, dear boy,' was the answer of Frederick William. Even the more cautious policy which prevailed, a partial agreement with Bismarck's persuasions (" the King of Prussia is a reed shaken with the wind '), 2 preserved Russian gratitude, and laid the foundation of a renewed friendship, priceless to Prussian policy.

Realizing with tragic imperfection the weakness and danger of his position, the number, strength and 1 I 850.

- Prince Albert's words. 
resolution of his foes, Nicolas, in the March of 1853 , by a series of ill-judged acts of violence, thus began to hammer the anti-Russian forces into an ardent cohesion. The Russian army was mobilized. The most un-diplomatic of men ('Menshikov will be Menshikov' $)^{1}$ appeared at Constantinople as special envoy from the Tsar. His double demandthe maintenance, on one side, of existing conditions in Palestine; on another side, the formal acknowledgment of the Russian right to protect the whole Orthodox Christianity of Turkey-was skilfully met. Practically the shadow was granted and the substance refused. The Palestine questions were left untouched, as Russia desired; the Russian 'Protectorate' of the Greek Church in Turkey was repudiated.

This reply was largely the work of the British Ambassador at Stambul, Lord Stratford de Redcliffe, the Stratford Canning of earlier days, whose keen and unsleeping Russophobia contributed so essentially towards the development of events at this time. The pro-Turkish enthusiasms of 'the great Elchi' (like Marschall von Bieberstein, fifty years later, Lord Stratford overshadowed all other envoys in the Ottoman mind) were destined in after years to be modified, but at this time he represented successfully enough a dominant feeling of his countrymen, and perhaps no man was more influential in steering the British ship of state into the rapids of the Crimean War. Queen Victoria in vain protested against the ' enormous

1 The Prince Menshikov of the Crimean age was the lineal descendant, and often the facsimile, of the Menshikov of whom Peter the Great said this. 
powers' and the 'hardly safe discretion' so vaguely entrusted to him.

Upon receipt of the Turkish answer, Menshikov quitted Constantinople, May 22, 1853, and a month later the Russian armies entered and occupied the 'Danubian Principalities,' our Rumania. Special rights of protection, both political and religious, were claimed by Russia in these Moldavian and Wallachian lands, and in this military occupation, without any declaration or recognition of war, the Tsar claimed to be acting within his essential rights. Those rights made of the Principalities a sort of pledge or pawn, ensuring Turkey's complaisance. If the Turks were not complaisant, full possession might be taken, for the time, of the pledge aforesaid.

Indignation ran high in Britain and in Austria, and the Tsar's precipitancy helped to keep Austria constant in the camp of his opponents. Not unnaturally, the Hapsburg State was extremely sensitive about the political condition of the Principalities. Their permanent incorporation in the dominions of the great Eastern neighbour obviously increased to a dangerous extent the Russian pressure, which would now run in a great crescent from Cracow to the Iron Gates of the Danube.

On the other hand, the Turkish hold over this Rumania had long been weak almost to powerlessness; the Turkish State itself, 'the Sick Man,' was widely regarded as merely a dying patient on the hands of his suspicious doctors, the Great Powers of Christendom ; a positive military security resulted to Austria from the continuance of the Ottoman suzerainty.

Vienna, therefore, protested with heart and voice 
-the memories of 1849 were already dim-and Austrian politicians declared with complacent cynicism that, instead of posing as the grateful dependents of Russia, they would yet astonish the world by their thanklessness. Any gratitude in such quarters, Austria's critics remarked, would be still more amazing.

The protests of the Hapsburg Government were backed by heavy concentration of forces on the Danube and along the Transylvanian frontier, and the flank of the Russian advance was threatened by a powerful and now unfriendly neutral, who might at any moment be transformed into an open enemy.

Yet the 'Vienna Note' of August I853 which formed a last and not ungenerous attempt at compromise, was endorsed by Austrian diplomacy-more warmly by Prussian-and showed a spirit far from irreconcilable.

On the advice of his Prussian friends-' we became considerable creditors of Russia in the Crimean War,' said Bismarck ${ }^{1}$ - the Tsar accepted a protocol which left him so largely in possession of the field. But Turkey's rejection of the proposals, the secret Western support of this invalid in unyielding firmness towards an unwelcome physician, and the haughty uncompromising spirit, the violent unwisdom, of Nicolas himself, the 'majestic autocrat ' now faced by so many enemies, destroyed once more the best hopes of accommodation.

A little earlier the British Queen is convinced that ' war will be avoided,' though she 'cannot exactly see how.' But now, in the autumn of I853, all pretence of that 'confiance la plus intime' and all hope of that

1 Reflections, i. 300 (E. trans.).

N.C.E. 
' complette et parfaitte identité de vues ${ }^{1}$ entre l'Angleterre et la Russie' so desired by the Tsar, had faded away, and on every side the currents were drifting towards war. On October 5 a declaration of hostilities was at last issued by Turkey.

Yet there were still some hopes of preserving peace between Russia and her Christian colleagues, the Great Powers (for men still clung to the idea of a Concert of Europe), till on November 30 Russia proceeded to another ill-judged act of spirited policy. Her Black Sea fleet, issuing from Sevastopol under Admiral Nakhimov, fell suddenly upon the Turkish navy lying in the roads of Sinope, and destroyed it utterly.

A definite state of war existed between the two Powers; such a naval action reversed-a Turkish surprise of Russians, the ruin of the Tsar's Euxine flotilla-would have been hailed with rapture; but things as they were showed the baseness of the Moscovite. Screams of horror arose over the Massacre of Sinope, ${ }^{2}$ and the Aberdeen Cabinet, still clinging to ideals of peace, was forced by the ferment of public opinion, and the increased pressure of the war leaders, Louis Napoleon, Palmerston, Lord Stratford, and the rest, to move a little nearer to war. As early as October 4, I853, the French Emperor had proposed that the French and British fleets, coincidently with the

${ }^{1} \mathrm{Q}$. Victoria, Letters, ii. 540-1, 546-7. Nicolas' spelling of French was ' catastrofic,' as he would have written it.

2 'Less than thirty years before (wrote Sir Arthur Gordon) an English fleet, with those of France and Russia, had destroyed a Turkish navy in a Turkish harbour... when both England and France were at peace with Turkey.... That... event had been ... lauded and rejoiced over.' 
Ottoman declaration of hostilities, should enter the Black Sea. Part of these naval forces had been brought up to Besika Bay just before midsummer-to the Dardanelles by mid-September ${ }^{1}$-by the New Year Napoleon and his friends bore down all opposition, and the joint navies entered the Euxine (January I3, I854).

The Tsar now at last abandoned his ideals of " confiance et identité de vues,' and broke off diplomatic relations, in February 1854, after some weeks of final hesitancy. And, at the beginning of spring, France and Britain, still hastening gently, joined Turkey in the Russian War (March 27, I854).

Only now did the Crimean War fully begin. It began with Russians and Turks facing one another across the Danube, as on the Armenian frontierthe 'Moscovites' on the Rumanian, the Muslims on the Bulgarian, bank-and with the French and British fleets at Varna guarding the Turkish coasts, watching the enemy shores opposite, and threatening at any moment to pounce vampire-like upon that toe of the Slav Empire which geography called the Crimean peninsula. On the flank of the Russians in Wallachia, and even somewhat on their rear, were the Austrian masses in sullen, unfriendly neutrality, awaiting events.

Now, after the unconscionable lingerings and hesitancies of the diplomatic struggle, followed in quick succession the early stages of the military conflictthe Russian advance across the lower Danube; the

${ }^{1}$ Even while urging this step Louis Napoleon is accused of negotiating secretly with Russia for alliance, on a basis of anything but friendship for Britain. 
successful Turkish stand at Silistria; the landing of French and British troops at Varna (May 29); the Austrian ultimatum (June 3 ) ; 1 and the consequent raising of the siege of Silistria, recrossing of the Danube, and retirement from 'Rumanian' soil (June-July I854).

Russian evacuation was immediately followed by Austrian occupation; and now Russia could hardly strike at Turkey in Europe save over an interposing Austrian body.

A new position, fertile with possibilities of peace or war, had thus been reached. Russia had been foiled in her aggressive action and had abandoned it; her troops had left the Principalities, had recrossed the Pruth, and were again entirely on Russian soil ; the immediate objects which the anti-Russian powers had proclaimed essential were attained. A truly peaceful inclination might here have found opportunities for a settlement. But a very different spirit animated the war-leaders and their followers in Britain, France, and Turkey; 'the hundred and twenty fanatical Turks of the Divan,' of whom Queen Victoria complains, ${ }^{2}$ had their parallels among the allies of the Ottoman; and all haters of Russia were emboldened by the astonishing feebleness of her military conduct. The Allies, therefore, now proceeded from an essentially defensive to an aggressive campaign.

They began by demanding that Russia should accept The Four Points-terms by which the Russian claims of protection over the Orthodox Church within

1 Even Prussia strongly deprecated permanent Russian occupation of the Danubian Principalities.

${ }^{2}$ Letters, ii. 555. 
Turkish territory, and particularly over the Principalities of the Danube, were to be renounced. Vehemently pressed by Austria, and advised even by Prussia, as a friend, to accept (in August, I854), the Tsar, after months of fresh hesitation, at last agreed (November 28). But the hesitation had been fatal. In these intervening months the situation had changed again - as usual to the detriment of Russia; and the very changes which finally induced Nicolas to accept terms somewhat humiliating to pride, but involving no actual loss, were decisive motives on the other side for more conclusive action against the yielding and defeated Russians.

Definite orders for an attack on Sevastopol, the head and heart of Russian power on the Black Sea, had been issued from London and Paris as early as the end of June. And when September arrived without acceptance of the Four Points, the French and British fleets at last made their swoop. On September I4 the Allied armies landed from the roadstead of Eupatoria, in the north-west of the Crimea. A week later the battle of the Alma (the river of the Apple) secured their footing in the peninsula, opened the siege of the fortress, and drove back the main Russian force into the middle of Taurida.

The rest of the war, despite excursions and alarms in the Baltic, the White Sea, Armenia, and Kamchatka, is mainly the siege of Sevastopol ; the remaining battles are chiefly attempts at relief, repulsed one after the other. Miserably conceived and executed, like the I870 enterprises for the relief of Metz, these Russian failures-Balaclava, Inkerman, and the rest-were in forcible contrast with the heroism, the skill, and the 
prolonged success of the defence of the fortress itself. A Menshikov, as ineffective in war as in diplomacy, was unable to raise the siege, but a Todleben was competent to prolong it to the danger, and almost to the exhaustion, of the enemy. Well seconded by the two Admirals, Nakhimov and Kornilov, the 'Russian Vauban,' the only man of genius whom the war brought forward on either side, now organized defence, as he was to organize blockade, twenty years later, in the siege of Plevna.

Sevastopol, mainly conceived as a great base for offence, was imperfectly protected on the land side; some have thought that the Allies, by a quick attack after the Alma, might have carried the place. But in any case, when they did attack in mid-October, Todleben had made good.

The first bombardment (on October I7) was blankly ineffective; on the other hand, the first attempts to raise the siege hopelessly broke down at Balaclava and Inkerman (on October 25 and November 5). Menshikov was still Menshikov.

Each side continued to fail grievously in its offensive ; each side put up a good resistance. The heroism of the Light Brigade charge at Balaclava was magnificent, as the French commented, but not scientific war. The siege progressed hardly at all; every assault was repulsed. Todleben was still Todleben.

The communications, the commissariat, the health and well-being of the Allied forces were mishandled, neglected, and impaired. In a Russian winter of terrible and unusual severity the climate of the Crimean

1 The Tsar's belated acceptance of the Four Points, after these reverses, came, as we have seen, too late (Nov. 28 ). 
plains, where the invaders lay, changed from oppressive heat to piercing cold. ${ }^{1}$

Bureaucratic corruption came to the help of natural difficulties, geographic and other; all the allied armies suffered horribly before Sevastopol. Nicolas, regaining hope from the misfortunes of his foes, boasted, it was said, of his two best generals, January and February. But the sufferings, the mismanagement, the corruption of the allies were more than equalled on the Russian side. And the natural difficulties of a road-less and rail-less continent proved worse than those of a long and intricate voyage over stormy winter seas.

The policy of Nicolas had been essentially shortsighted. Because impenetrable Russia had baffled the great Napoleon, striking at her heart, impenetrability had been made a maxim of state. There must be no roads and no railways to let in the invader, who would then weary himself to death wallowing in mud, or wandering in forests and swamps. But the new attack, of the 'little Napoleon' and his friends, was not at the heart, but at the foot, well-shod, at great expense, yet perilously exposed. Now it was Russia that needed communications. Russian troops, under the fostering care of scoundrelly contractors, went lame, starved, sickened, and died, literally by myriads, on the immense marches. High roads, or 'iron roads,' there were none ; ${ }^{2}$ steamers, or other serviceable river craft, but few. A Russia with the communications of IgI4-to ask nothing

1 The South Crimean Riviera was parted from the main theatre of war by the lovely mountains of the Yaila range.

2 Except only the Moscow-St. Petersburg line. 
better-could have brought up such forces, by the end of the first October, as to drive the Allies into the sea. In I854 the strength of the Empire could not be fully brought into action. Every other defect was crowned by the dishonesty of the administration under Nicolas I. Most Government officials, most chinovniks - their name was legion, their power was great, 'and the Tsar was far distant'-seemed to live and work only to make private profit out of the nation. The official world of Russia was peerlessly corrupt. To its greed, its ignorance, and its conceit, the issue of the war was largely due.

The Emperor Nicolas had paid infinite attention to drill and discipline, to military appearance, to the numbers of his host, and the splendour of their parades. But he had never effected, nor perhaps understood, real efficiency, military or other. And all the corruption had been endured by him and other honest Russians, because at least the old autocracy had ensured success in the past and promised the same in the future. Since Ivan the Great, since the Wars of the Roses in England, the Tsardom had scarcely ever suffered a serious reverse, ${ }^{1}$ had usually emerged with advantage from every conflict. To Nicolas himself Alexander had bequeathed a position higher and more august than had ever been reached by Slavonic Tsar, or Orthodox Emperor, since the conversion of the Rus; and what had he made of it ? Proud beyond expression in the past, he felt shame beyond endurance in the present.

Early in the January of 1855 the accession of Sardinia-Piedmont to the ranks of his foes, added

1 Except for the Time of Troubles, 1605-13. 
another drop to his cup. He was determined not to survive the disgrace of such defeat, such collapse. In the sharpest cold of the Russian winter he courted death, going straight into the open in the light indoor clothes of the Russian stove-warmed house. 'Malade déjà d'une forte grippe, il sortit sans pelisse par un froid de 23 degrés.' The physician in attendance, it is said, in vain tried to stop this act of suicide. 'You have done your duty, now let me do mine.'

On his death-bed he recognized that his system, in great measure, passed with him. 'My successor (he used to say) may do as he will. As for me, I cannot change.' 'Il ne pouvait pas changer, il ne pouvait que disparaître. Il était l'homme d'un autre âge, une singularité dans l'Europe nouvelle.' Yet the need of change, the necessity of a new policy, filled his last thoughts. 'Thou must make peace, thou must set free the serfs; it will be hard for thee 'so the dying father, it was told, had whispered to his son. The Tsar-Liberator thus received his commission (March 2, I855).

Meantime, the naval enterprises of the Allies in the Baltic, in the White Sea, and on the Caucasian and Siberian coasts, had ended in failure, some in disaster. On the side of Armenia, Russia was gaining the upper hand, and the fortress of Kars was closely besieged. And on and within the Chinese border the skill and daring of Count Muravev was winning for 'Moscovy,' and for Alexander II., an Amur frontier, and an outlet on warmer waters.

But everything essential still turned on the Crimean struggle. And here the confusion and exhaustion of 
the Russian military system ; the accession of SardiniaPiedmont to the coalition; the growing anti-Russian tendencies of Austria; the vigour of the new French army-chief, Marshal Pélissier; the quickened resolve of French and British governments and peoples, stung into fresh energy by transport and hospital scandals-all foretold the approaching end.

Todleben still repulsed assaults, as in mid-June, 1855, but two months later a last attempt at relief was broken up in the battle of the Chernaya or Black River, ${ }^{1}$ and early in September the fortress fell (September 9-II, I855).

Matters now moved towards peace-at the price of Russian submission. The capture of Kars in November, 1855, and Muravev's successes in the Far East throughout this year, to say nothing of the skill and heroism of the Sevastopol defence itself, gave some consolation to national pride; while the most haughty spirit was forced to recognize the inequality of the struggle, and the peril of internal revolution. A great reaction against autocracy, or its abuses, began to show itself. 'Stand forward, Tsar, before the judgment-seat of history and of God. You have trampled truth underfoot, you have denied freedom. By your pride and obstinacy you have exhausted Russia, and raised the world in arms against us. Bow down before your brethren; crave pardon; ask advice. Throw yourself into the arms of the people. There is now no other salvation.'

When such was the language of the popular pamphlets; when the new Tsar, himself a man of such

1 Where the new Italian contingent fought with effect, and Leo Tolstoi took part as a volunteer in the Russian ranks, Aug. Io, $\mathrm{I} 855$. 
innate moderation and sense, had received from his iron father such a death-bed commission, Russia was clearly open to proposals of peace.

For peace, however, even yet, such proposals must not be too dishonouring, and the British attitude appeared almost implacable. The Island nation was infuriated by its many repulses and mischances, and above all by the 'Baltic muddling,' and the last failure before Sevastopol, at the Redan (September 8). The total separation of the Crimea from Russia was loudly proclaimed as a minimum condition, while the complete destruction of Russian naval power in the Euxine was, of course, fundamental. Nor was this all. Future Russian aggression could only be effectively guarded against by the cession of Finland, Poland and Georgia, as well as of Taurida. Thus Palmerston expressed the general feeling ${ }^{1}$ of his school.

But Louis Napoleon held different views, and France was easily converted to those views. The French Emperor had no intention of pursuing a vendetta in order to gratify his British ally. However mistakenly, he still thought of Russia as a possible friend and even helper. He would fain avoid anything destructive of such hope. Facts were to show that he had already crossed the border-line of safety, and secured for France a generation of Russian unfriendliness. But the Imperial dreamer hoped and believed the contrary, and on such belief he based his policy. And that policy, in a word, was immediate peace with Russia on the most reasonable terms. If British views were different, he was perfectly prepared to go behind the back of Britain.

${ }^{1} \mathrm{Q}$. Victoria, Letters, iii. 232. 


\section{2 \\ NINETEENTH CENTURY EUROPE}

He therefore now agreed with Austria and Sardinia on the diplomatic settlement. Austria was to present, as an ultimatum to Russia, the real peace conditions agreed on between Paris and Vienna-for the Hapsburg government, as before, though still willing to wound, was yet afraid to strike.

As a matter of form, Britain's consent was obtained ; but British statesmanship regarded the rejection of the terms as pretty certain. 'If refused, as they almost must be, the rupture between Austria and Russia is a decided step gained by us.' 1 But to the surprise and disgust of the victims of Russophobia ("we have been infernally humbugged,' was an outbreak attributed to Lord Clarendon ${ }^{2}$ ) Russia accepted the Austrian demands.

In a Congress of the Great Powers and other states at Paris, the terms of settlement were laid down (February 25 to March 30, 1856) -in the main lines exactly corresponding to the Austrian ultimatum.

The three main clauses, or groups of clauses, defined the 'neutralization of the Black Sea'; the abolition of the Russian protectorate, spiritual or other, of Greek Christians in Turkey; and the cessions exacted from Russia.

By the first was declared the abolition of all (that is, of Russian) naval power in the Euxine-the removal,

${ }^{1} \mathrm{Q}$. Victoria, Letters, iii. 193.

${ }^{2}$ And so Morier (Memoirs, i. 144) ' have had visit from Layard ... fresh from that pepper-plantation H.M. Embassy at Constantinople ... Lord Stratford having bellowed himself out-no one caring any more for his bark, which they have found far worse than his bite, and our whole influence lying prostrate under that of our blessed French allies.' 
it was hoped, of that maritime threat to the Ottoman Empire and the Mediterranean, which had developed since Catherine II. won for the Empire of the Tsars a great southern sea-board.

By the second, the vague, insidious danger of a Russian domination in the whole Ottoman world, under the pretext of religion, was ended; the mine was stopped.

By the third, moderate as it was, and exacting only the cession of Southern Bessarabia, the Russian frontier was moved away from the Danube ; territorial proofs of success, however slight, were given to the Allies; and the military position of Turkey (it was asserted, if not believed) was rendered safer.

For the rest, the Turkish Empire was declared to be admitted to the public law and concert of Europe, while the Powers pledged themselves to resist any change in the status of their client, and repudiated all right to interfere between the Sultan and his Christian subjects. Towards the latter the Padishah graciously recorded his 'generous intentions.'

The Crimean War, thus ended by the Treaty of Paris, seemed at the time a great achievement, yet history or experience has not endorsed its work, save in a manner unexpected and undesired by the chief actors. At the same time, no European war of recent generations has had deeper and more vital consequences in the end. As in the Syrian Crusades, the direct results are Dead Sea fruit ; but matters of some moment indirectly follow. Fate denies pitilessly on one side, and grants with astonishing liberality on another. To the prinicpal 'victors,' Britain, France, 
Austria, Turkey, the Crimean drama brings, in the next decades, disappointment and often disaster. To the 'defeated' Empire it ensures a measure of internal regeneration, and new developments of external energy, but fixes a limit of power and influence in Europe. Never again does the Tsardom stand on the same pinnacle of greatness. For ere Russia has recovered herself, another nation is replacing her at the head of Continental politics.

The Great Power which ultimately gained most from this cycle of events was the one which stood wholly apart from the struggle, the wind-shaken reed whose wavings and turnings perplexed the British Court so grievously.

Next came the profit of the little state which entered at the eleventh hour, with forces by themselves so ludicrously inadequate to this battle of giants.

In other words, the Bismarckian Empire, the new German unity under Prussian leadership, was the chief, the most astonishing, and to some the most unwelcome result of the Crimean War, and of the new international conditions that war produced; while the unity of Italy, under Sardinia-Piedmont, a change only second in importance to the New Germany, equally arose from the same events.

But, among the obvious and expected consequences, what disillusion.

The regeneration of Turkey, for which the Allies had fought, in which they professed so stout a belief, and which had been proclaimed so touchingly in the Treaty of Paris, proved, of course, once more a dream. In the Bulgarian atrocities of the 'seventies, and a thousand other things, the most obstinate Turcophile 
could not but read a disquieting comment of history on the career of the reformed penitent. And the dismemberment of Turkey, the defeat of her armies, and the prostration of her power, in 1878 , as expressed in the San Stefano treaty, were nearly as absolute, it might be said, as Nicolas or Catherine could have desired.

But by the time of San Stefano, Russia was no longer able to gather the full harvest: one sowed and another reaped.

In I870, crushed by the rising German power, compelled to witness and to contribute to a new German Empire, France sought in vain for a helping hand from her natural ally. At the news of Sedan, the Tsar, who had ended the Crimean War, and concluded the Treaty of Paris, drank to the prosperity and glory of the King of Prussia.

As to the Hapsburg Monarchy, 'always against Austria ' became from I855 one of the deepest feelings of the Russian government and people. 'An open enemy was better than a false friend.' Only deep draughts of revenge could wipe away the memory of that ingratitude. At the tomb of John Sobieski, Nicolas had commented on the folly of delivering Austria; never again would that folly be repeated. Russia hailed with delight, in I866, Austria's defeat and expulsion from Germany and Italy. And, in the Franco-German struggle of 1870 she was ready to fall upon the rear of the Dual Monarchy, if that Monarchy went to the aid of France, and struck for the restoration of her old position in Central Europe.

Britain, which had so long cultivated, and so often profited from Russian friendship, now found in Russia 


\section{NINETEENTH CENTURY EUROPE}

a permanent antagonist, an ubiquitous rival, a subtle counter-mining force, throughout the rest of the century. The tide of 'Moscovite' expansion, far enough from any British borders, home or colonial, in the Near East, was only diverted by the Crimean War, Englishmen found with indignation and alarm, into more perilous channels. By 1865 the Russian outposts in Central Asia were approaching the borders of British Indian influence. By 1885 the Russian Empire ran along, and pressed upon, the whole of Northern Persia and Afghanistan. By 1895 the Tsar's troops were firmly established on the ' Roof of the World,' within a thirty-mile view of the British frontier. In the same decades the Russian thunder-cloud darkened and deepened over China; Russian pioneers, with increasing insistence, penetrated the Chinese possessions, Tibetan and Central Asiatic, to the North-East of India.

The hopes and assumptions cherished by Palmerston and his friends-an end of the 'Russian menace' to the British Empire-were scarcely realized.

Two days after the fall of Metz (October 29, I870) Russia announced that she would no longer be bound by the Black Sea clauses of the Treaty of Paris. And in the middle of next January the London Conference ratified the Russian demand. The French power was in the dust, and the Russian repudiation of Napoleonic arrangements was a natural result of French disaster, as it was an outcome of the RussoPrussian friendship on which the earlier policy of Bismarck, and of Alexander II., so largely rested.

The Russo-Turkish war of $1877-78$ restored to the Slav Empire the Southern Bessarabia which had been 
ceded in 1856 . The same war finally gave her that Kars which in the Crimean conflict she had a second time taken and relinquished. And the subject Christians of the Ottoman world, treated with such scorn in the Crimean age, at last gained a large measure of deliverance after twenty years (1877-78).

\section{ADDITIONAL NOTE TO CHAPTER IV.}

The civilization-history of this epoch (1853-56) gives us again a noteworthy record ; e.g. in Natural Science, Helmholtz' work in optics and solar phenomena, and Bessemer's (and Siemens') improvements in steel manufacture; in Anthropology, the discovery of the Neanderthal skull and the Zurich lake-dwellings; in Geographical exploration, the discovery of some of the chief features of Tropical Africa-Ukerewe or Victoria Nyanza, Tanganyika, the course of the Zambezi-by Speke, Burton, Livingstone, and others; in Belles Lettres, Thackeray's Newcomes, Kingsley's Hypatia and Westward Ho, Keller's Der Grune Heinrich; in History, Mommsen's Roman History, Milman's Latin Christianity, Giesebrecht's Mediaeval Empire (Kaiserzeit), Motley's Dutch Republic-all masterpieces. Much was also done about this time for improvement in material well-being; the reconstruction of large parts of Paris carried out by Baron Haussmann, under Napoleon III., especially brought credit to the Second Empire. A socialistic tendency (State-socialism particularly) was now becoming more apparent in thought and action. 


\section{CHAPTER V.}

ITALIAN UNITY AND OTHER CHANGES, I857-6I

THE Crimean era is immediately followed by the practical accomplishment of Italian unity, and by the first clear indications of a New Germany, shaped by Prussia. The latter begins a little earlier, but is slower in development.

In the autumn of 1857 the feeble and capricious absolutism of Frederick William IV. ${ }^{1}$ came to an end with the mental collapse of that weak, headstrong, sentimental, good-hearted, artistic nature, whose 'rich fantasy' had always 'lacked wings, as soon as it entered on the domain of resolve.'

In his place, first as Regent then as King, now stood his younger brother, William, the 'cartridge prince,' hated of Liberalism (especially since I848), scorned by those intellectuals to whom Liberalism was a dogma.

The two brothers offered a contrast remarkable enough. The emotionalism of the elder was followed by the stern, practical sense of the younger (already

1 Frederick William III., King 1797-1840, was father both of Frederick William IV., who reigned 1840-57 [died I86I] and of William I., who governed 1857-88, and reigned I86I-88. 
a man of sixty-two) ; a strange incapacity for selecting councillors, and taking counsel, was succeeded by a fortunate, 'Elizabethan,' aptitude for profiting by the genius of others; impulsive and ill-balanced purpose, ever varying, lacking in all leadership, gave way to a strong will and a sound, if not a soaring, intelligence.

No Minister could reckon on the steady support of Frederick William in any policy; with the new ruler 'you could be certain that if you stuck to him, in no danger would he leave you in the lurch.'

Frederick William, like Nicolas of Russia, had been ' a doctrinaire, with a fanatical hatred of the Revolution.' Guided by this, he had preferred an unprofitable alliance with Austria and with the lesser German dynasties-a weak deference to Russian dictationto any policy of Prussian advancement.

To his brother, as to Bismarck, the ultimate aim of statesmanship was the attainment of "German unity under Prussian leadership'-Deutschlands Einigung durch Preussen. How and when to effect this was less clear to the new sovereign-it was revealed to him by the statesman with whom, in I862, he entered on a life-partnership.

Within a week of his accession to the Regency (October 23-29, I857) William had 'provisionally,' that is, practically, appointed General Helmuth von Moltke to be Chief of the General Staff of the Prussian army, and General Albrecht von Roon to be Minister of War: stronger proof could not have been given of the vigour of the new régime.

At the New Year the marriage of his son and heir, the Crown Prince, afterwards the Emperor Frederick, 


\section{IOO NINETEENTH CENTURY EUROPE}

with the eldest child of the British Queen, the Princess Royal, helped to bind far more closely old ties of friendship and of blood between the dynasties, the courts, and, to a less degree, the countries.

In no slight measure the international position of the Prussian Government won advantage from this alliance. Not once or twice, in after years, did the support of Prussian interests seem to Queen Victoria almost a duty. Never did a marriage of the heart play more usefully all the functions of a diplomatic move.

The Union of Italy, after the earlier failures we have noticed, is really commenced, and at that time could only have been commenced, with French help; it is perfected through Prussian aid and French defeat. Cavour arranged the former with Louis NapoleonCavour's successors, and circumstance, settled the latter with Bismarck.

'Italy as a nation'-nothing was ever more truly said-' is the legacy, the life-work, of Cavour... Others have been devoted to the cause of national liberation; he knew how to bring it into the sphere of possibilities ; he made it pure of . . . . factious spirit ; led it away from barren Utopias . . . . steered between revolution and reaction.' The Piedmontese nobleman who did this; who saved Italy 'from foreigners, evil principles, and madmen'; who, with Bismarck, is the master-builder among European statesmen of the nineteenth century, represented in his own name and person the French element in the Italian race. His native languages were French and Piedmontese patois rather than literary Italian. The Italian physical type was not very prominent in this blonde 
gentleman. Nor was consummate statesmanship suggested by the cheery, blinking eyes, half closed behind their spectacles, the kindly humorous mouth, the fringe of ragged beard, the ill-fitting clothes, the whole air of a good-natured, unworldly, slovenly farmer that went with him. Few could recognize here, without intimate knowledge, the man of deep cunning, of ready and skilful falsehood, of unsurpassed tenacity, of synthetic and prophetic purpose, who, like his northern rival, reached a great ideal by devious paths, and claimed indulgence of his country because he loved her much.

From the time that he first directed the policy of Piedmont, from the October of 1852 , he recognized in the France of Louis Napoleon, in the dreamy ideals of the new Bonaparte, his chief and almost his only possible, ally. Later, indeed, he formed hopes of Bismarck, in whom he saw, even then, ${ }^{1}$ a champion of nationalism, and a natural friend of Italy. But he died before the Prussian alliance gave Venetia to Italy-his foreign helpers were, effectively, the French.

The beginnings of the French alliance were secured by the entry of Sardinia into the Crimean struggle. Matters were taken further by Cavour's part, admittedly so brilliant, in the Congress of Paris ; never did French policy in that great meeting look for Sardinian support, and Italian cleverness, in vain.

An abortive attempt at assassination helped his policy. When the refugee Orsini came over from London and threw bombs at Louis Napoleon on his way to the Opera, killing eight of the Paris onlookers ${ }^{2}$ In 1858 . 
and injuring one hundred and forty, one might have expected any result, rather than that which followed. But, instead of repelling, it impelled. The strange enthusiasms of the French Emperor were not frightened away from action, but startled into immediate movement. Instead of renouncing his predilections for a nation of assassins, he saw in the incident, as it were, a divine rebuke for his slackness in the Italian cause, and a warning of destruction if he still delayed. Most of his resentment he vented on Britain-the asylum of murderers. The pilot of Italian nationalism he invited to a secret meeting, under pretence of a health cure, at Plombières in the Vosges, and on June 20, I858, the two schemers were both harmlessly drinking the beneficial waters. But, under cover of this most natural proceeding, and taking advantage of this meeting, apparently so casual, the Emperor and the statesman fell to discourse of politics, and agreed on joint action against Austria at the first favourable opportunity. ("Non seulement nous prendrons la première occasion de faire la guerre à l'Autriche, mais nous chercherons un prétexte.') ${ }^{1}$ Napoleon undertook to attack with 200,000 men, Cavour to support with half that number. No peace was to be signed till the Hapsburg rule had been totally expelled from Italy; then the Italian peninsula was to be rearranged in a fourfold state-system; in this plan Napoleon hoped to see a triumph of French influence over the greater part of the country.

The whole of Piedmont, Lombardy and Venetia, the bulk of the old Cis-Alpine Gaul, was to form the

1 So Sir James Hudson from Turin (Feb. 28th, 1859) reported the Franco-Sardinian understanding. Queen Victoria, Letlers, iii. 426, n. 
new .kingdom of Sardinia or of North Italy-while Tuscany, the lesser Duchies to the South of Lombardy, and the northern portions of the Papal States, were to form a kingdom of Central Italy, under an estimable scion of the House of Bonaparte-Jerome, the 'PlonPlon' of French popular wit, who was to marry the Princess Clotilda, a daughter of Victor Emmanuel.

The Pope was to retain the City of Rome and the Patrimony of St. Peter, or immediate neighbourhood of Rome, ${ }^{1}$ and his security in the Eternal City was to be guaranteed by a permanent French force.

And, last of all, the Kingdom of Naples, or The Two Sicilies, left undisturbed under this arrangement, but with its Austrian friends defeated and removed, was certain to undergo a revolution, from which Napoleon trusted there might come a restoration of the line of Murat.

This New Italy, by the Plombières conditions (or at least in Napoleon's assumptions), was to be loosely united in a sort of federation, under the presidency of the Pope, and the protection of France. And, besides the indirect gain of such a vast extension of influence, France was to have the direct return of territorial cession. All of Italy that remained on the French side of the Central Alpine chain was now to be united with the French Empire-the Highlands of Savoy, the town and shorelands of Nice, the cradle of the Sardinian dynasty, the birth-place of Garibaldi.

With many of these arrangements Cavour was naturally at variance, but as yet his hostility must be secret. He had already given his sanction to a

${ }^{1}$ Forming an oblong territory on the west side of Italy from Orvieto to Terracina. 
national society, ${ }^{1}$ whose aim was the union of all Italy under the House of Savoy (1857), and this, and no French-protected federation, was his real purpose.

After Plombières, the one thing needful was immediate war, and this was diligently sought, with astonishing directness.

Napoleon gave the first sign. At the New Year's reception of ambassadors at the Tuileries he officially expressed to the stupefied Austrian his regrets that the relations between Paris and Vienna were ' not as good as they had been' (Jan. I, I859) ; a week later Victor Emmanuel, opening Parliament at Turin, declared himself ' not insensible to the cry of woe from so many parts of Italy' ; and the two declarations, rightly pieced together by statesmen and populace alike, were greeted with ominous enthusiasm throughout the north and centre of the Peninsula, and even in the south. From one of her three proverbial woes, men said, the land would soon be free-

'Italy's three plagues that grieve her Are friars, Austrians, and fever.'

To the direct question of the British envoy a few weeks later-'Do you mean to attack Austria?'Cavour artlessly replied that the Italian question was becoming so complicated that it was impossible to say what might happen. ${ }^{2}$ But what did happen was exactly to his mind.

1. Do what you can. Before the world I shall deny you, like Peter,'-Cf. Ia Farina in Seignobos, p. 350, Histoire politique de l'Europe contemporaine.

Feb. 28, 1859. 
For Austria now met her enemies, open and secret, perhaps unwisely, certainly to the grief of some of her best friends, and the delight of her foes, with an ultimatum to Sardinia.

'The madness of Austria,' exclaimed Queen Victoria, ' has put them in the wrong, and changed feeling here, which was all that one could desire, into the most vehement sympathy for Sardinia.'

Although Austrian sympathizers still hoped 'to throw the blame of the war on France '- ' the wicked folly of Russia and France has brought about this crisis' 1-and although the British Foreign Office prophesied a dangerous strain on French resources, and the possible overthrow of the Empire, all hope of British intervention was now abandoned. 'The course which Austria is taking deprives her of all claim on the support or countenance of England.'

'No government in this country' (Lord Derby warns the Queen), could hope to carry public opinion in taking an active part in opposition to France and the Italian National Movement. And - if the slightest pretext be afforded for doubting British neutrality, an anti-German feeling would be excited, fatal to the administration, and seriously embarrassing to your Majesty.' 1

The campaign in North Italy, which opened on April 26, soon turned against the Austrians. The Franco-Sardinian victories of Montebello and Magenta, and the evacuation of Lombardy by the Austrians, produced violent and triumphant movements of nationalism in North Central Italy far to the south of

${ }^{1}$ Q. Victoria, Letters, iii. 418-19, 42I-2, 430. 
the theatre of war. Tuscany and the lesser Duchies of the North Centre drove out their princes, with cries of 'Meet you again in Paradise'; Bologna, Ferrara, the Romagna, expelled the Papal Legates; even Umbria nearly threw off the Papal authority. Everyone was for 'liberty as in Piedmont'; everywhere union with Sardinia, or the dictatorship of Victor Emmanuel, was proclaimed (June I859).

The vehemence and the scope of these uprisings began to make clear to Napoleon that his dream of a French Protectorate, however veiled, over most of Italy, was hardly feasible.

And at the same time Prussia began to move. For now, under the vigorous leadership of the Regent, she gave signs of acting as Bismarck had desired her to act in the Crimean crisis, and as he desired now. She mobilized her forces-prepared, when the hour struck, to take decisive action on that side where lay her dominant interests. In the height of the Italian struggle, when France was pushing to the wall a German power, so long the premier German state, what a chance for Prussia to act as the champion of Teutonism against the eternal Gallic foe, and to march in aid of hard-pressed Austria, at the head of all the armies of the German world.

The Austrians, meantime, had fallen back within the shelter of the great ring of fortresses known as the Italian Quadrilateral-Mantua, Verona, Legnano, and Peschiera. And the Franco-Piedmontese success at Solferino on the Midsummer Day of I859, while it helped to secure the fruits of the Italian revolution in Central Italy, showed afresh the strength of the Austrian defences, the vigour of their resistance, and 
the need of heavy sacrifice for the forcing of the Quadrilateral.

Napoleon, therefore, already disillusioned as to French profit from the Italian Risorgimento, and daily in receipt of more threatening news from the Rhine - eager to help Italy, for a consideration, but hardly so enthusiastic for the creation of a self-sufficient Italy, scorning dependence on France-glad to win prestige by victory, but no more resolute than in the Crimea to create a mortal enmity-now stopped short in war and policy alike. In place of further military effort, he arranged a meeting with the Austrian Emperor.

At Villafranca, near Verona, an armistice was arranged with enviable speed and thoroughness; all the main lines of the subsequent peace were here laid down (July II, I859). Austria was to cede most of Lombardy, but to keep Venetia and all the fortresses of the Quadrilateral-two of which lay within Lombard boundaries. To save the face of Austria, the cession was to be actually to Napoleon, who would transfer it to Sardinia. And the Duchies of North Central Italy were to be restored to their former rulers and their former state, but by the votes of their peoples, without foreign intervention. The plebiscite thus arranged resulted, of course, in the exclusion of those rulers by an overwhelming vote, and in union with the realm of Victor Emmanuel, which thus, as the latter said, ' surrendered Savoy and Nice for Central Italy.'

Napoleon's action was none the less a bitter disappointment to Cavour, and all the ardent spirits of Italy. Much as they had gained, they had expected so much more. 
They had assumed these gains in Central Italy, and more, and they had reckoned on Venetia; to crown all, they had, with some confidence, expected an answering movement in the south, the overthrow of the Bourbons at Naples, and the practical union of almost the whole peninsula in one State.

Cavour was blind with rage. Heaping reproach and insult upon his King, abandoning himself to paroxysms of grief, he resigned office.

But after six months Cavour was again at the head of the Government, planning fresh strokes, fresh conquests.

' They have stopped me from making Italy by diplomacy from the north; I will make it with the Revolution from the south '-in this spirit the Count turned to the party of Mazzini and Young Italy, and let loose the splendid hot-head Garibaldi upon the Kingdom of Naples.

This aged and decrepit state, whose tradition had long been political devotion to Austria, and spiritual devotion to Rome, was bubbling with revolution-a cauldron from which certain forces were now endeavouring to raise youth and strength in union with Sardinia.

One Francesco Crispi, a lieutenant of Mazzini's, who as Prime Minister of Italy twenty years later, brought his country into the Triple Alliance (I88I-3), and often bore heavily upon the extremists to whom he had once belonged, organized a decisive revolt, to begin in Sicily. With Garibaldi, he gathered on the Italian Riviera the famous Thousand Volunteers, embarked them at Genoa, and landed them at Marsala, west of Palermo (May I4, I860). 
Very skilfully, very typically, did Cavour play the double part necessary at this crisis. Outwardly, a correct neutrality was observed; secretly, everything was done, or permitted, to promote the venture. The enlistment of volunteers was made easy; the Garibaldians were allowed to get arms from the national arsenals; all the difficulties of embarkation were smoothed away. The Sardinian fleet guarded Garibaldi's passage without seeming to do anything; it was enough (as their instructions hinted) to keep between the Thousand and the Neapolitan war-ships. British vessels were also allowed to encourage and help Garibaldi, and the expedition was compared by Lord John Russell to the Glorious Revolution of I688. Naples was now about to take the consequences of misgovernment, ' which had no parallel in Europe.' 1

Garibaldi and his Red Shirts won the whole of Sicily with astonishing ease and speed, between the middle of May and the end of July. Next came the Neapolitan mainland. In mid-August the ' new Crusader ' crossed Messina Straits, and from Reggio (captured on August 2I) he marched straight on Naples, the Bourbon troops scarcely attempting to fight 'this second Satan,' and the people greeting him as 'our second Christ.' As he advanced his progress became more than ever a triumph, easy and peaceful. At Salerno he left his carriage (he had already given up the pretence of riding at the head of a hostile force), and took the train to Naples; the chief delay that followed was caused by the enthusiasts who climbed on to the engine. The capital seemed to rise as one man to welcome him.

${ }^{1}$ So Lord John Russell wrote to the British Minister at Turin in this year. 


\section{IO NINETEENTH CENTURY EUROPE}

In the midst, even because, of intoxicating success were serious dangers. The new Dictator made no secret of his plans : after Naples, Venice and Rome. Whether such plans involved war with both France and Austria appeared to him unimportant. Nothing could withstand the wishes of a 'free people.' Cavour judged differently. And, recognizing the imminent peril to all his life-work, he now prepared to stop his dangerous allies himself. 'Italy must be saved from madmen.' By a series of brilliant and audacious movements in strategy and diplomacy he brought down the Sardinian troops, through the Adriatic coast-lands of the Papal States, into Campania, between Garibaldi and Rome. The Dictator, meanwhile, had been checked by unexpected resistance in the north-west corner of the Naples territory, especially at Capua; the Papal opposition to the passage of the Piedmontese was easily overcome ; and on October 26 , I860, the royal and republican Liberators met at Teano. A huge majority in the Two Sicilies voted for incorporation with the dominions and subjects of Victor Emmanuel; and with South Italy went the eastern portion of the States of the Church, already overrun. Cavour knew the French minimum-the Patrimony of Peter, from the Apennines to the sea, and from Orvieto to Terracina. If so much were left to Pio Nono, Louis Napoleon would not intervene. It was safe now to add Umbria and The Marches to the seizures of I859.

Thus Piedmont-Sardinia had almost become the nation. Only Venetia and the Roman Patrimony still remained outside; and in response to a vote of his Parliament at Turin, Victor Emmanuel (" the 
symbol of our regeneration' even to Garibaldi) took the title of King of Italy (March I6, I86r). Florence was made the capital until Rome could be secured.

Since the days of Theodoric the Ostrogoth, ${ }^{1}$ and of heathen England, there had been no semblance, far less the reality, of national unity in the old Imperial land; the Empire of Rome had not grown from an Italian nation, had not definitely created or recognized such a thing. And after the fall of Rome, except for the Gothic Kingdom (so brief and so worthless as an expression of nationality), all efforts to realize a political Italy had failed.

For the achievement a price was paid-Cavour himself. Broken by his ten ycars of leadership, by his three years of 'race with victory,' he died a few weeks after the proclamation of his ideal (June 6 , I86I). 'A free Church in a free State'...' anyone can govern in a state of siege,' were dying murmurs of the great statesman, which expressed some of his last and wisest thoughts. ${ }^{2}$ It was natural to fear, or to anticipate, that in the hands of clumsier men the coach of state might not go forward with the same prosperity. 'Le cocher est tombé du siège,' said Louis Napoleon, "il faut voir maintenant si les chevaux iront s'emporter, ou rentrer à l'écurie.' But in spite of some bad driving, disaster did not befall.

1 A.D. 493-526.

2 The German problem also occupied his mind. 'This German' Federation is an absurdity. It will break up, and German unity will be established.' But the Prussians were terribly slow to move. - They will take 50 years to do what we have accomplished in three.' Cavour had no small expectations of Bismarck, even in 1858 . 


\section{ADDITIONAL NOTE ON CULTURE HISTORY, I 859-6r}

(a) In Religion slight movements both in an 'Old Catholic' and in a 'Modernist' direction are observable within the Roman Communion, and another interest of these years is the development of the 'Broad' and Critical School in England. 'Our Essays and Reviews Debate' begins in 1860. Perhaps the chief excitement lies in the controversy on Evolution, which seems to the old Orthodoxy subversive of fundamental Christian conceptions. In 1859 Tischendorf discovered the Sinaitic MS. of the Bible, giving one of the earliest forms of the New Testament.

(b) In Literature, Art and the 'Humanities' we have Tolstoi's suprene War and Peace (1860); the earliest work of Erckmann-Chatrian (1859, etc.); Fitzgerald's brilliant condensation of the Rubaiyat of Omar Khayyam; George Eliot's master-pieces, Adam Bede and Silas Marner (1859, r86r); some lesser work of Victor Hugo's ; and in History and related subjects, Montalembert's Moines de l'Occident (r86o); Dahn's Kings of the Germans; Maine's illuminating essays on Ancient Law (I86I); Max Müller's Science of Language (1859); and some of Oppert's best work on Assyrian.

(c) In Natural Science and Social Progress, Charles Darwin (who had already announced his theory of Evolution in 1858 , simultaneously with Alfred Russell Wallace) published the Origin of Species by Natuval Selection, an eternal landmark in thought (1859). The 'war between Religion and Science' broke out afresh, on the battle-ground of Darwin's theories and researches, with extraordinary fierceness and obstinacy. In the same years we have some important early work of Pasteur's, and the investigations of Wilhelm Bunsen and others on the Solar light and Spectrum Analysis (1859, etc.).

In Exploration much work is done in Africa of the first importance. Livingstone discovers Lake Nyasa (1859); Speke and Grant discover Ukerewe, or Victoria Nyanza, the main source of the Nile. 


\section{CHAPTER VI}

THE BEGINNINGS OF THE BISMARCKIAN AGE, I $859-63$

THE Villafranca armistice, the close of the FrancoItalian struggle with Austria in I859, was, among other things, we have seen, a conspicuous Prussian success-in the eyes of those who saw. It was no longer safe (says Bismarck, truly, if somewhat truculently) ' to count upon our timidity' after the change on the throne. Austria and France, for various reasons, dreaded Prussia's entry into the war, and were prepared to go far in compromise if that could be prevented.

Louis Napoleon (the Prussian Government believed), if he had seen any 'intention of war' in Germany, at the opening of the Italian struggle, would at once have changed the theatre from Lombardy to the Rhine. The Prussian policy ('my policy,' said the Regent in a famous interview) had therefore been to allow France to become 'fairly engaged' in Italy before developing a threat ' at the head of the German Confederation.' It was 'the task and will of Austria' to prevent a salvation so dangerous, a rescue which must have meant something like a subordination of N.C.E. 
Vienna to Berlin. And for such an escape the sacrifice even of Lombardy did not seem too great.

More than ever the events of Villafranca convinced the Regent (his real advisers needed no convincing) of the opportunities of Prussia-if only she were made strong enough. Already he saw supremacy in Germany (that Suprematie in ganz Deutschland which he claimed in I866) within the reach of Prussian ambition. The sum of his resolutions (writes Ranke in I860) ${ }^{1}$ was to leave the German Princes undisturbed in their sovereignty, but to effect a union in military matters. 'He fully grasped the idea that the military power comprised in itself the sovereignty.' But for this purpose, as Roon and Moltke did not forget to urge, Prussia's army must be developed. Her military system, unchanged since the reforms of Scharnhorst and the War of Liberation, must be brought up to date. To meet the increase of population since I8I4 (the ten million Prussians of the Vienna Settlement were now nearly eighteen) the calculations of the national conscription must be altered. Hence the army bills, which were laid before an astonished and unwilling House of Representatives in the autumn of 1859 , $^{2}$ and which with their thirty-nine new regiments of infantry and their ten new regiments of cavalry, raised the annual levies from 40,000 to 60,000 men.

This was the question which, "like the fat kine [sic] gradually ate up all others, became a question

1 Conversation with the Regent, June 13, 1860.

2 Early in the same year Bismarck had been sent to ' cool on ice,' i.e. promoted from Frankfurt (" the Federal Diet's own earth' whose every exit and entrance he had now mastered) to be Ambassador at St. Petersburg, ' the highest post of Prussian Diplomacy.' B. i. $221,222$. 
of constitutional life and death, and broke the neck of one minister after another, until it got into the hands of Bismarck.' 1 Again and again the Prussian Commons threw out the bills, but the Regent, possessed by these plans 'with an intensity with which the Reformation may have possessed Luther,' and supported in some measure by the Upper House, held on his way. On New Year's Day, I86r, the standards of the new regiments were consecrated. On the morrow (January 2) the Regent was at last King, in fact as well as in name; for his brother, who had so long passed away in mind, now died in body. More than ever did William now persist. He would ' rather abdicate than give up one man or one week's service.' But when, after so many failures, after the dissolution of the old Chamber and the election of a new one, equally hostile, the army bills were again decisively rejected on August 22, I862, and the ministry once more resigned, things seemed to point, not towards success, but towards abdication. The Crown Prince was a Liberal, dear to all Liberals: let him take up the headship of the State.

It was in this mood that Roon (and the logic of events) at last brought King William, who had so long wavered in this personal question, ${ }^{2}$ to offer to Otto Bismarck, ${ }^{3}$ the supposed champion of the most rigorous Toryism, the Prussian premiership.

The new Minister, who was to prove himself the chief maker of a new Germany, and the most creative

1 M. i. 323.

2 I found the old inclination towards you, with the old indecision,' wrote the War Minister on June 4.

- Otto E. L. von Bismarck-Schönhausen, born I815. 


\section{6 NINETEENTH CENTURY EUROPE}

and powerful European statesman of the age, was now forty-seven. He was at the zenith of his powers of mind and body. Health which had been impaired he had won back. He was again in full possession of his six feet of physical strength-the bold rider, the skilful fencer, the good swimmer, walker, and runner, the man of huge appetite and alarming thirst, ${ }^{1}$ the lover of nature, of all country life, of birds and animals. His mind was already tempered for any conflict No politician of the time was perhaps endowed with equal penetration, subtlety, alertness, or initiative; none had more breadth of view, flexibility, or constructive power. Caution and daring, critical and creative faculties, balanced one another in his policy and temper: the result was an extraordinary surety of judgment-' he seldom made a mistake.' His foresight was almost unique among the statesmen of that age. Bitter and unscrupulous as he could be in his hatred, he had as a public man ' an intelligence superior to all passion.' Like Cavour, like certain theologians, he believed, and practised, when it seemed advantageous, an ' economy of truth.' No more than the Italian leader did he mince his falsehoods when he dealt in them: pecca fortiter, to both minds, as to Luther, was a sound maxim. Yet neither seems to have thought that the best way of meeting difficulties was, usually, to lie-even ' for the benefit of the country.' And the patriotic end was as real (and so perhaps as much an excuse for the means) in the one case as in the other.

Young Bismarck had won a Parliamentary reputation in $1847-50$ as a conservative and royalist stalwart,

1' It is with my mouth I have sinned most (said he) in eating, drinking, and speaking. 
a Junker of Junkers; from I85I he had built up a reputation as a diplomatist and statesman-first at the Frankfurt Diet, where he had withstood Austria to the face (I85I-9); then in St. Petersburg, where he had appreciably strengthened the Russian-Prussian entente (1859-62); then for a short time in Paris, where he was almost daily expecting the summons, which at last came from Roon on September I862'Periculum in mora ; dépêchez-vous.'

Once arrived in Berlin, his fate was soon decided. When the King next bemoaned himself to Roon: 'What are we to do ?' and to the reiterated suggestion: 'Appoint Bismarck,' objected that he was far away and might not accept, the answer was easy and conclusive. 'He is here : he will stand by you.'

An interview with the Crown Prince, who had summoned Bismarck to see him first of all, gave the King, however mistakenly, another reason for desponding: ' $\mathrm{He}$ is no good either; he has already been to see my son.' 1 But on September 22 the two had a decisive conference at Babelsberg Schloss. Into the despairing heart of his sovereign (' I have resolved to lay down my crown,' began William) Bismarck put fresh life, new hope; he was ready to fight for the army reform to the end; and 'I shall not abdicate,' was the King's conclusion. 'It is my duty to continue the battle.' As for the Minister, he preferred to perish rather than to yield. 'This view was then absolute with me,' both 'because I considered the negations and phrases of the Opposition as... disastrous ... and because I cherished such feelings ...

1 I.e. He knows I am giving up : he is putting himself right with my successor. This was entirely a misconception. 
for William I. that the thought of perishing with him appeared, under the circumstances, a natural and congenial conclusion to my life.'

When Bismarck became Minister-President the change of spirit in the Prussian Government since the beginning of the Regency, five years before, had already begun to effect a corresponding change in German public opinion. The practical success of Italian unity strengthened and deepened the change.

The ideals of 1848 woke to fresh life. Members of that Frankfurt Parliament, from which so much had been vainly hoped, spoke up once more in the cause of national union, and in the Assemblies of various Minor States aspirations for such union were expressed. It was in reference to these, and out of his deep belief in their well-meaning futility, that the new Prussian premier made his famous, startling, and, to so many, abhorrent, declaration - that 'the great questions of the day were not to be decided by the making of speeches or the votes of majorities, but by blood and iron.'

For to his mind ${ }^{1}$ the German deadlock, or balance, whether for good or evil, could only be ended by the definite victory of one of the two leading powers, and by the expulsion of its rival from the Germanic world. The ideal of so many, that one of these rivals might be so reduced in power and territory, that she herself might be treated as a minor state, and fall, like the rest, under the leadership of the victor ${ }^{2}$ - was an

1 Except for a brief and final experiment in co-operation with Austria, under Rechberg (1863-4).

2 This was a favourite form of the so-called 'Greater Germany' conception. 
impossible solution at this time, for 'Vienna could not be governed from Berlin as a dependency,' nor Berlin from Vienna.

But in Prussia, as in the rest of Germany, this Lesser German solution ${ }^{1}$ was still perhaps the hope of the minority, and was in any case distasteful to much of public opinion. To cut the Gordian knot by a 'war of brothers' was an heroic remedy which was still violently decried. And Bismarck's personality and work as yet brought him scant popularity. He had taken office to 'tame Parliament.' $\mathrm{He}$ was the autocratic King's last resort in the struggle with the national will over the army bills. To the Liberal majority in the Berlin Diet he appeared 'a mere bully and absolutist of the old type.' His self-confidence, his mordant humour, his irony and flippancy, ' exasperated and inflamed.' The violence of feeling was such that he was strongly urged by friends to transfer his property to his brother. The progressive journals declared that such ministers as he, acting against the constitution, were responsible in their lives and fortunes. Some of the most bitter hoped one day to see him picking oakum for the benefit of the State. ${ }^{2}$ For he was, in their eyes, as in those of their English sympathizers, the head of the ' wicked and unscrupulous faction,' whose tool King William had become, and whose 'passions' the sovereign had 'lashed himself up to share.' 3

The great builder of alliances was even reproached -it was a favourite taunt at the time-with isolating Prussia in Germany and in Europe, and exposing her,

1 I.e. A new Germany, without Austria.

ㄱ. i. $313 . \quad$ M. i. 334. 


\section{I20 NINETEENTH CENTURY EUROPE}

friendless and detested, to every conceivable combination of foes.

But what was really happening? On taking office Bismarck set himself to develop friendship with Russia. He apparently aimed at something more than an 'understanding,' something less in form than a technical alliance, but apparently capable of being converted at will into the latter. The Polish insurrection of 1863 furnished the Prussian Minister with an opportunity which he used to the utmost, and the close of that struggle found Russia bound to him by hooks of steel. In the whole war period of the Bismarckian time-to the end of the French struggle-the Russian entente was a chief support of his policy and his system. 'Bare is back without brother behind it.'

The Crimean era gave him the germ of this opportunity: his 'slavic' embassy developed, his premiership completed it. To the Russian government likewise, above all to Alexander himself, the friendship seemed precious, and the Tsar Liberator would have gladly seen at this time the conclusion of a military alliance, and even apparently the opening of a joint attack upon Austria, France, and Britain. 'Wearied of the chicaneries of these Powers,' and of their constant efforts to promote trouble for Russia, as in Poland, he now urged the King of Prussia, his uncle and most intimate friend, to draw the sword with him, and rid himself of these intrigues by common action. ${ }^{1}$

Bismarck's refusal of this suggestion did not produce any change in relations, as between the governments an intimate harmony remained till after the completion of the new German Empire.

${ }^{1}$ B. ii. $68-74$. 
Throughout the Polish crisis, therefore, the Prussian Government, to the indignation of the Liberals, gave Russia its full support. Prussia still retained, by the Vienna Settlement, some valuable Polish territories, including some of the oldest and most living areas of national life, and the most ancient capital of the country. ${ }^{1}$ A successful rising in Russian Poland could hardly be without effect over the border-at least in Posen.

The Prussian frontier was therefore guarded with strong cordons of troops, with orders for decisive action in case the Poles should take refuge in Prussia, should endeavour to recruit in Prussia, or should try to use Prussian territory as a base of operations against the armies of the Tsar. ${ }^{2}$

More than ever this policy made the MinisterPresident the abhorred of Liberals, distasteful even to many a Conservative. But he was little disturbed by the storm of his unpopularity. He was grasping the substance, he believed-his critics were concerned with shadows. 'Where shall we be,' he would have said, 'if we gain the sentimental approval of the whole neutral world, and lose our one chance of a strong ally'?

Since the Crimean War Russia had experienced

1 Gnesen.

${ }^{2}$ These measures were settled by the Russo-Prussian 'Alvensleben Convention' (concluded, for Prussia, by General Gustav von Alvensleben, Feb. 1863), which 'stood for the victory, in the Russian Cabinet, of Prussian over Polish policy ... determined by the personal decision of the Tsar, in opposition to... his Ministers . . . The Convention said check-mate in the game which anti-Polish Monarchism was then playing against philo-Polish Panslavism within the Russian Cabinet.' B. i. 342-3; see also B. i. 107-8, II 4-16, 236-8, 334-341. 


\section{I22 NINETEENTH CENTURY EUROPE}

changes deep and wide. Above all, she had reformed herself, in some measure. The autocracy had not sacrificed its control, but for the time, under the most generous-hearted of the Tsars, ${ }^{1}$ it had abandoned repression and reaction. It had reverted to the spirit of Alexander I. in his happiest time. Immense social alterations had been carried out, in a Liberal sense, and to some extent the people had been taken into partnership. The emancipation of the serfs, by which forty-three millions of unfree or semi-free received liberty, was established by the law of February I8, I86r. This widest of anti-slavery measures provided that the serfs should ' at once' enjoy the civil rights of the 'free rural classes '; that the authority of the proprietor should be replaced by communal selfgovernment; that the rural communes should, 'as far as possible,' retain the land they actually cultivated, paying the proprietor certain yearly dues in money or labour; and that the Government should, by means of credit, assist the communes to purchase the lands ceded to them 'in usufruct.' Practically, the landowners gave up about one-half of the land hitherto considered theirs, and received one thousand million roubles in compensation. Thus a matter affecting the whole national life (as nothing else did), and recognized as fundamentally important since the days of the Emperor Paul, 2 was at last settled in a way which seemed to give new life to the Empire, to bring her into the blessed company of Liberal States, and to wipe out the shame and reproaches of the past.

1 Alexander II., the Tsar-Liberator, I855-I88I.

I796-1801. 
Nor was the progressive movement limited to the emancipation.

The policy of isolation and anti-modernism was frankly abandoned. A network of railways, a fleet of merchant and passenger steamers, mainly for inland traffic, were constructed: the time would soon come when the Volga would bear more traffic than the Mississippi. Commercial treaties were concluded. The yearly publication of the Russian budget was commenced, to improve the national credit. Schools were founded all over the country. The Universities were opened to all. Something like a participation of the 'classes,' if not of the 'masses,' in local affairs and organization, was provided in the Zemstvo system - to accustom the nation to self-government, and to prepare for a constitution.' Trial by jury was revived. A new and better code of laws was published. The Old Free Russia, Russia as she had been before the Tartars, seemed to be returning.

But in thus making peace with the modern spirit, the Imperial Government found (and was to find more and more) that it could not escape warfare.

And first with Polish Nationalism, stimulated by the success of its Italian sister.

The emancipation of the serfs and the liberal régime of the new Tsar in general had themselves encouraged the Poles to rise. And even if the Imperial concessions were to cease, the Liberal bent to alter, and hopes of federal autonomy to fade, the Polish leaders trusted, with foreign help, to attain to something better, the complete independence of a restored Polish Republic. They put some hope, moreover, in 


\section{24 NINETEENTH CENTURY EUROPE}

a Russian civil war, in a conflict of crown, nobles, and peasants, of which there were some deceptive signs. They had an exalted and exaggerated belief in the capacity of Polish courage and genius; and they put a natural, but most unfortunate, reliance on the aid of Liberal countries and Liberal parties throughout Christendom. Alexander's measures of conciliation ${ }^{1}$ - the new Polish Council of State, the native governorgeneral and provincial governors, the free local councils -were therefore taken as mere proofs of weakness; and the rioting of I86I, and the murder plots of this and the following year (narrowly missing the new Viceroy, on his entry into Warsaw) soon led on to open insurrection.

To cripple the malcontents, the Government had ordered a new military levy of one in two hundred. In this levy the country folk were to be spared; the leaders of the town disorders were to be impressed on the night of the I4th January, I863. But most of the marked men, warned in time, escaped to the forests, and became pioneers of a guerilla warfare which now broke out all over Poland.

In this rising, however, national action was hardly realized. For, if all the nobles, gentry, land-owners, townsfolk and priesthood, rose with fiery zeal, the peasantry, still degraded and depressed as in the eighteenth century, ${ }^{2}$ bore far too bitter a grudge against their lords, great and small.

The Polish demands, moreover, were almost suicidal. The insurgents would be satisfied with nothing less

1 E.g. in the summer of 1862 .

2 'Dogs, as these abominable people call them,' was a seventeenth century comment on the relations of Polish peasants and landowners. 
than the Great Poland of old days-before the First Partition of I772. All Western Russia, ${ }^{1}$ in other words, up to the neighbourhood of Kiev, of Smolensk, of Vitebsk, was to be torn from the race which ethnically dominated it, and from the political system which had recovered it from the alien rule a century before.

Russian national spirit rose with a new enthusiasm against such demands. Once more, as in the Napoleonic Wars, the autocracy had the people behind it. Even as to truly Polish lands it was perhaps hardly natural (however desirable) for the Tsardom or its Russians to acquiesce in simple resignation. 'It is impossible for Alexander,' wrote Leopold of Belgium to Queen Victoria, 'to give up these provinces, which are prosperous, and have been Russian for a long period. Their existence will be improved, as truly much has been already done... But the Russians as a nation ... can never... give them up. A war for that purpose would for England be a fool's play.... Such a Poland as the Garibaldians wish ... . would be in close alliance with France. ... Prussia could not exist.... Austria would find itself in the same position.' ${ }^{2}$ But on such intervention the Polish cause depended.

To some extent the Western Powers repeated the tactics of the Crimean epoch.

Once more the campaign opened with the diplomatic protests of France and Britain, backed by Austria. But there was now a marked want of confi-

1 To say nothing of Prussian and Austrian possessions-Posen, W. Prussia, Galicia.

:Lord Granville's Life (Lord Fitzmaurice ed.), i. 446-7. 
dence and of cordiality. British suspicions of Napoleon, French resentments against Britain, ran high. The volunteer movement of I859-' Riflemen, riflemen, riflemen, form '-was an avowed answer to the threats of the French military party against the 'harbourer of assassins.' The annexation of Savoy and Nice, in I860, was viewed with extreme dislike across the Channel. British public opinion began to believe that every proposal of Napoleon's covered some design of aggrandizement. French feeling responded by angry unwillingness to serve the purposes of Britain. When, therefore, the French Emperor proposed, after much negotiation, a European Congress for the Polish question and other vexed matters, the Palmerston Government curtly refused. ${ }^{1}$ 'We are not in purpose,' they might have said, with the anti-Papalists of old, ' to fulfil thy covetousness.'

In this crisis, moreover, the Bismarckian policy of the Crimean time and the Russian desires of this time, ${ }^{2}$ might have been forced into complete accord by any repetition of Crimean action, and an attack upon Russia might have revealed that it was not against Russia only that the allies would have to contend.

But Russian policy now played a better defensive, and before any Western League could be formed, the Polish War had been decided. While the revolt was still dangerous, there was a show of courteous attention; Prince Gorchakov was moderation itself; diplomatic notes were exchanged, diplomatic interviews held, in abundance. But when the military

$$
\begin{aligned}
& \text { Cf. Gladstone's Life (Morley), ii. I } 7 \text {. } \\
& \text { Cf. pp. } 78,8 \text { r. }
\end{aligned}
$$


struggle was decided, as it was in effect by the end of 1863, the Russian Chancellor and his sovereign rejected all intervention, with the enthusiastic support of the Russian people, and the evident co-operation of the Prussian Government.

The situation, thus developed, found the mediators quite unprepared for action. As Beust said in 1870 : 'Je ne vois plus de l'Europe.' By the spring of 1864 the revolt was at an end.

In resettling Russian Poland, after the revolt, the Tsar's Government was guided by one of the ablest statesmen, and along the lines of Milyutin's reconstruction the Provinces of the Vistula were governed down to the outbreak of the World War (IgI4). No subsequent revolt broke the stillness.

First of all, every trace still remaining of Polish autonomy was now removed, and the Vistula Governments were made, even more absolutely than before, part of the Russian imperial system. On the other hand, the Polish peasantry were made freeholders; the land of Poland was divided between this emancipated peasantry and the old land-owners; and the woods and pastures, still left to the lords, were carefully allowed to remain subject to the undefined common rights of the peasants. Thus peasants and landlords always had a good subject of quarrel, and the Russian Government a good excuse for interference. At the beginning of the rising the insurgent leaders had vainly tried to win the peasantry by the offer of some kind of freehold. Now this offer, translated into fact by the Russian enemy, made a new insurrection more than ever hopeless. Well might a Russian 
statesman boast: "We hold Poland by its rights of common.'

But after Milyutin was laid aside, first by paralysis, then by death, the Russian Government began a system of anti-national repression and proselytism, aimed at everything essentially Polish. Literature, art, science, language, religion alike experienced this policy. By every means it was sought to turn Poles into Russians, and a population of over a million, it was claimed, was drawn or forced from the Roman into the Greek Church by the end of the century.

But the value of these conversions was indeed a doubtful matter, and a stubborn Polish Nationalism persisted under every disability, danger and temptation-resolutely hostile to Russia, and increasingly hostile, as time went on, to Prussia and the new Germany created by Prussia.

Strengthened by the Russian friendship, Bismarck refused to participate in an Austrian scheme for a special Congress at Frankfurt-on-the-Main-the Frankfurt 'Diet of Princes'-nominally to promote federal reform, really (the Minister suspected) to make the Austrian 'Presidency,' in the German world, more effective. Extraordinary efforts were made to induce the Prussian King to attend, and there was a desperate diplomatic struggle over the matter. It was one more example of Bismarck contra mundum. The King of Saxony in person (a messenger peculiarly acceptable) brought the repeated and most pressing invitation of the Diet on August I9. Prussia was the only absentee, except a couple of the tiniest princi- 
palities: would she spoil this fair prospect of United German action ? 1 'My master did not find it easy to resist that move. Over and over again he reflected : "Thirty reigning princes, and a King to take their messages." Not till midnight did I obtain his signature to a refusal. When I left him, he and I were both ill ... . with the ... tension.' Bismarck's uncompromising reply asserted Prussia's absolute equality with Austria in any reformed Confederation of German states; claimed the same right to the Presidency; and suggested a "Parliament representing the whole German nation.' Thus early did the Conservative extremist forecast, to the bewilderment of the world, his coming alliance with Liberalism. Three years later the suggestion was again to be made, more forcibly -and realized, in the new North Germany of 1866.

The Prussian attitude ruined the Congress. To the Austrian demand that it should come to its conclusions without Prussia, the Lesser States (as anxious to avoid an Austrian as a Prussian domination) replied with a practical refusal: Try Prussia again.

Count Rechberg, ${ }^{2}$ for Austria, replied with the angry warning that the road to Berlin was no longer, or harder, from Vienna than from any of the Lesser German Courts. Out of this situation a PrussianAustrian Entente resulted, which was to control the Schleswig-Holstein question, in its new and fateful developments, and which carried through the Danish War of 1864 .

1 But Prussian co-operation in this Congress of 1863 ' would have closed the road to German Nationality,' Bismarck does not hesitate to say, B., i. 370 .

2 Johann Bernhard, Count Rechberg, born I806.

N.e.E. 


\section{NINETEENTH CENTURY EUROPE}

For years past, ever since his early Frankfurt days in I85I-2, Bismarck had leaned strongly towards certain conclusions on the German problem, which were definitely Klein-Deutsch and anti-Austrian. These conclusions involved the defeat and expulsion of Austria from Germany, and the construction of a Teutonic United States, or Federation, without Austria, and under definite and exclusive Prussian leadership. Such a programme the 'eccentric fellow,' with perplexing candour, stated to Disraeli in the summer of I862, on his flying visit to London: "When the army has been brought to . command respect, I will ... declare war upon Austria, burst asunder the German Confederation, bring the ... smaller states into subjection, and give Germany a national union under the leadership of Prussia.'

But there was still, he thought, a possible way of averting this 'civil strife,' this 'war of brothers,' and his friendship with Rechberg, the 'irascible and honourable' nobleman who directed Austrian policy from 1859 to 1864 , inclined him once more to make trial of this. 'Our relations,' he said to an Austrian statesman in December I862, 'must become better or worse. I am prepared for a joint attempt to improve them.' But Austria, he added, must treat Prussia as holding equal rank in the German world, and permit the free exercise of Prussian influence in the north. She must, in effect (as he said on another occasion), move her centre of gravity towards Buda-Pest. ' Hypnotized by Bismarck,' as men said at the time, irritated by the attitude of the Lesser States in the Diet of Princes, disillusioned of Austria's 'Presidential ' claims, and with no fanatical horror of the idea of 
Dual Control, Rechberg was now, in I863, 'won over to act in unison with Prussia.' It was the last episode of the old Federation ' brotherhood,' the last repetition of the conditions of $18 \mathrm{I} 3$, before the destruction of the ancient order in I866. It was also prophetic of the lasting alliance of Berlin and Vienna from I879-on this Bismarck himself lays special emphasis. But it rested mainly on the personal relations of the two Ministers. "When we recalled the suddenness with which Rechberg, in his irritation, broke with the Middle States, and allied himself with us, without them and against them,' the possibility of a ' new evolution' at any moment had to be admitted. Rechberg's nature, so susceptible to affection and admiration, was 'splenetic and rash to an unusual degree,' and the Austrian ship of state was 'of so peculiar a construction' that its oscillations could hardly be reckoned on. The marvel was that the new Entente lasted so long and did so much. ${ }^{1}$

1 Cf. B., i. 368-38r. 


\section{CHAPTER VII}

\section{THE UNITY OF GERMANY}

\section{Part I. Germany and the Danish Duchies}

THE question of Schleswig-Holstein, unkindly termed ' the most complicated that has ever occupied European diplomacy,' is of no little importance. For it is not only the scene of the first Bismarckian War, of the first act in the military history of German Unity, but it is an important and official cause-though not the chief or only one-of the Austro-Prussian War, and of that reconstruction of Central Europe in 1866 by which so much was ended and so much begun. It also brings about a conspicuous defeat of the Palmerstonian policy of British interference in all European matters, and marks the beginning of a new age of British isolation.

Schleswig, Slesvig, the Northern Duchy, had, in bulk, always been reckoned Danish, since the beginning of the modern nations-though occasionally some of the strongest of the German emperor-kings, as in the tenth century, had made a strip in the extreme south a German border-' mark.'

Holstein, the Southern Duchy, containing the 
splendid port of Kiel, and the 'little Hamburg' of Altona, had on the other hand (like tiny Lauenburg, ${ }^{1}$ really a part of Holstein), been mainly Germanic, from the same starting point of modern history, which in this region is certainly the tenth century. But in the times of Teutonic disintegration and weakness in the Later Middle Ages and the Classical Renaissance, the Danish Kings acquired practical control. They became, for this purpose, Princes of the Empire, and members of the Germanic Body, as Counts or Dukes of Holstein; and this position continued-to speak more exactly, it was restored-after Napoleon's fall, by the Vienna Settlement.

Even in the modern centuries wherein German Nationalism appeared dead, German racial activity, more and more preponderant over Danish, rather increased than diminished. Thus Holstein was more thoroughly Teutonized than ever, and all the south of Schleswig began to change. When German Nationalism awoke after I8I2, one of the objects of its new ambition was to redeem the Germania irredenta of the north-Holstein at least, a large part of the sister duchy likewise, cried the patriots of the vanguard.

Between $\mathrm{I} 848$ and $\mathrm{I} 85 \mathrm{I}$ three Germanic risings, backed by some German Confederate and some Prussian help, convulsed the Duchies; but for the moral (and other) support of Britain, Russia and Sweden, the Danes might then have been ousted even from Central Schleswig. But the European situation was not yet favourable for this revolution. Russian policy was still in large measure of an anti- 
German and anti-Prussian complexion, as Nicolas I. had made it ; the Crimean age had not yet regrouped the Powers; Bismarck was not yet directing the policy of Prussia; and by the Protocol and Treaty of London, ${ }^{1}$ which guaranteed the unity and integrity of the Danish State, the incorporation of the Duchies with Denmark, technically forbidden, was practically recognized.

At the same time the little German Federal fleet, rare and wonderful example of Confederate action in those days, created by the Frankfurt Diet mainly for the prosecution of the Danish struggle, was sold by auction, ${ }^{2}$ by decree of the same Diet. ${ }^{3}$ Much of it was acquired by Prussia.

Everything seemed to smile on the Danes. But they now became victims of success. Although by the Treaty of London they had undertaken to give good treatment to Germanic elements under their rule, the complaints of these elements were soon louder than ever. German feeling, German language, local privileges, it was declared, were all suffering under a ruthless Danism. In October, I855, a new national constitution was proclaimed for the whole Danish Kingdom, including the Duchies. Under threat of war from the German Federal Diet, King Frederick VII. at first agreed to leave Holstein out of the operation of what later became so famous as the November Constitution. 4 But, finally, under pressure

1 Aug. 2, 1850 ; May 8, 1852.

2 This 'bringing to the hammer' of the Federal fleet was somewhat surprising, in view of German feeling even then. 'In no question during the last twenty years has public opinion in Germany been so unanimous,' said Bismarck on June I, I865 (B., ii. 20).
June, 1852 .
- Nov. 1858 . 
from his own Nationalists, and under the irritation of Frankfurt threats without, and Teutonic agitation within, he decreed the absolute incorporation of Schleswig with Denmark, and the closer attachment of Holstein (March 30, I863), and promoted the law of the following November, by which this policy received the sanction of the Danish National Assembly.

On the first introduction of this law, ${ }^{1}$ the Frankfurt Diet decreed Federal Execution, or German Confederate war against Denmark, ${ }^{2}$ and after the Royal assent had been given ${ }^{3}$ by the new King, Christian IX., to the Danish Unitary Constitution, German Federal troops - mainly Saxon and Hanoverian - entered Holstein, and occupied the whole province (December, I863). The Danish forces withdrew without fighting, and from this time Danish sovereignty disappeared in the Southern Duchy. Danish soldiers were no longer to be seen from Hamburg, on garrison in Altona; Kiel was no more a station for the Danish fleet.

Behind the Federal forces came the Duke of Augustenburg, the best claimant to the succession in the eyes of most German Nationalists. Schleswig-Holstein, freed from Danes, a new Little German state with Augustenburg as its prince-such was the popular solution. But Bismarck planned otherwise. He had no wish to add to the Lesser States yet another, which would probably vote against Prussia in the Diet, on most occasions, and at every crisis might impede his schemes for the reconstruction of Germany. The only solution satisfactory to him was incorporation into Prussia: this alone would justify active interference
1 Sept. 29.
Oct. $x$.
sov. 18. 


\section{36 NINETEENTH CENTURY EUROPE}

on Prussia's part. 'From the first I kept annexation steadily before my eyes.' 1

The Prussian Minister, we have just seen, had established a new understanding with the Hapsburg Monarchy, and an Austro-Prussian alliance in the Danish question was the chief result of this. Vienna joined in secret and exclusive agreement with Berlin, to settle the matter of the Duchies, without the interference of other German states, or of the Diet.

In pursuance of this policy, vainly rejected by the Frankfurt Assembly, Bismarck and Rechberg delivered a joint ultimatum at Copenhagen, demanding the repeal of the November Constitution before the New Year. The Danes declared with much reason that compliance was impossible $;{ }^{2}$ the. King could not legally do this without the Rigsrad." 'The Rigsrad of the Old Constitution had been dissolved and had no longer legal existence; a new Assembly could not be summoned before January II, I864; there was not time.' Again, a new Assembly would have to be summoned according to the new November Constitution, the very thing whose abrogation was insisted on so sternly.

Lastly, help from Britain was confidently expected : had not the British premier, my Lord Palmerston, declared on July 23,1863 , that any such disturbance as was now being made would show the disturbers 'that it would not be with Denmark alone with which they would have to contend ' ?

But these 'senseless and spiritless menaces,' at which Disraeli scoffed, were followed by nothing

1 Cf. B., ii. 9-Io.

${ }^{2}$ Cp. Headlam, Bismarck, 2 I I.

8 Parliament. 
effective. Palmerston found himself without a Continental ally, and faced by strong opposition in his own Cabinet and at Court. In January the Austrian and Prussian troops passed through Holstein; on February I they entered Schleswig. Here the Danes stood at bay; but in Holstein the new invaders only met the 'fraternal' 'cordons of Saxons and Hanoverians, who sullenly watched their 'brethren,' as they took over the Federal task, and relegated Federal execution to obscurity.

Across the Danish peninsula, in its Southern Schleswig neck, ran the ancient and still perhaps formidable rampart of the Dannevirke. A desperate defence of this was widely expected; but it was abandoned without a serious struggle, and the 'gaunt and wolfish marauders' (as the London Times depicted the soldiers of the aggressive Powers) overran most of Schleswig, and even crossed the frontier of Jutland. But the Lines of Düppel, the Düppeler Schanzen, on the east coast of the province, covering the most obvious approaches to the Islands and to Copenhagen, were stubbornly held: the storming of these works, on April I8, mainly by Prussian troops, after a month's investment, caused vehement rejoicings all over Germany, deep heart-searchings in Denmark. A truce was arranged a few weeks later $\mathbf{~}^{\mathbf{1}}$ and another Conference was held in the same London where the unlucky Protocol and Treaty of $I 850$ and $I 852$ had been arranged.

But no agreement could be arrived at. Danish obstinacy, still clinging to the belief in British intervention, and Prussian ambition, sometimes pursuing blocking tactics, sometimes offering compromises, 
ruined all hopes of peace; and war was resumed at Midsummer.

'You came into the Conference,' said Lord Clarendon to the Prussian Ambassador, 'as masters of the situation, and as masters... you leave it. Have a care how long that will last.' ' Je ne veux plus jamais' -wrote Clarendon at the same time-' rien avoir à faire avec cet homme sans foi ni loi qui s'appelle $M$. de Bismarck, ni celui qui est son nègre, M. de Rechberg.' 1

The second and final chapter of the war was soon finished. The Prussians at the end of June passed over from the Danish main into the Isle of Alsen, ${ }^{2}$ while that Danish mainland was almost wholly overrun by the invaders. Scarcely any of Jutland was left unoccupied, and as the naval defence had failed, an immediate attack on Copenhagen had to be expected. And still no foreign help, British or other, appeared.

At the end of July the Danish Government at last despaired, and on August I preliminaries of peace were signed which were embodied on 3oth October in the formal Peace of Vienna. By these Denmark ceded all her sovereign rights in the Duchies to Prussia and Austria conjointly.

As Lord Palmerston frankly told the British Parliament in the 'Danish Debate' of June 27, I864, the British Government and nation had felt great sympathy for Denmark, which ' in the beginning had been wrong, but had wished to put things right.' But ' early in the transactions ' it had been ascertained that

1 Cf. C. Grant Robertson, Bismarck, I78-9.

June 28-29, I864. 
neither France nor Russia would take active measures on behalf of Denmark. Thus the whole brunt of the war would have fallen on Britain, and such a war the Government could not recommend. Not unnaturally, and from a very representative position, could Disraeli and Robert Cecil (the 'great Lord Salisbury ' of the next generation) express the general feeling, in this and other debates, that avowed ' pacifists' could hardly have so mishandled national policy. 'If Mr. Cobden had been Foreign Secretary ... I believe this country would occupy a position proud and noble compared to that she occupies at this moment. She would at least have been entitled to the credit of holding out no hopes which she did not intend to fulfil, of entering into no engagements from which she was ready to recede.' 1

Having won the Duchies, the German Powers had to settle their future.

Immediately after the Peace of Vienna, Prussia, reluctantly supported by Austria, insisted upon the Federal troops evacuating Holstein-which they had now occupied for some ten months, and where their place was now taken by Austro-Prussian contingents. Bismarck likewise communicated to Austria the Prussian conditions as to the Duchies-already offered to Augustenburg and rejected by him, as now by the Vienna Government (December I864). They amounted to practical Prussian control. This once granted, Prussia would acquiesce in the erection of a new

1 See e.g. Annual Register, 1864, pp. 74-99 (int. al., Parliamentary Debates of Feb. 9-12 ; April 9; April I9; June 27; July 4. Lord Robert Cecil is here quoted from July 4. Cf. also Morley, Gladstone, ii. I16-120 ; Morier, Memoirs, i. 362-418. 
petty German state of Schleswig-Holstein ; otherwise, not. The renewed tension in Austro-Prussian relations was emphasized by the retirement of Rechberg, which inevitably followed. Austria began again to oppose Prussian policy at every point, and the decisive struggle seemed at hand. The whole great German problem was at last to be solved, men were sure, as a result of the little Danish question. But one more postponement-one more agreement-was yet to be. An Austrian partition-proposal, offered at the eleventh hour, to the surprise of many, was accepted, to the still greater astonishment of the quidnuncs, and by the Convention of Gastein, 'the cracks' were 'papered over' (August I4, I865).

These surface-repairs in Austro-Prussian harmony were effected by an arrangement which a later statesmanship knew as Spheres of Influence. Austria was for the present to occupy and administer Holstein; Prussia, Schleswig. Lauenburg, too insignificant for much jealousy, was to be sold to Prussia.

But whereas Prussia's position in Schleswig was unimpaired, Austria admitted in Holstein a considerable, almost over-mastering, share of Prussian partnership-and Bismarck thus secured practical control of the port of Kiel ; the right of cutting, at some future time, the canal already so much desired; the inclusion of the Southern Duchy in the Prussian Zollverein; and other rights of less value.

Gastein closed the first voyage of Bismarck as pilot of the Prussian ship of state. On some angry minds, as on Morier's, the 'supposed brilliancy of his successes during the past... months failed to produce any 


\section{THE UNITY OF GERMANY}

impression except the deep disgust which well-ordered minds feel for successful villainy.' But the Minister's sovereign saw results of 'signal circumspection and discernment.' Under his leadership, it already seemed to King William, 'Prussia had gained a position worthy of her history, and promising a fortunate future.' In recognition of this, and of his 'conspicuous merits,' Bismarck was now made a Count. 
Part II. The War of I866 and the Reconstruction of Central Europe.

In July, I865, a month before the Truce of Gastein, while as yet there was no break in the Austro-Prussian clouds, King William, in his own language, ' had his hand on his sword hilt.' 'Gastein gave peace,' but by April of 1866 matters had again become worse than ever. So the Prussian monarch declared, and it was true. ${ }^{1}$

The 'papering of the cracks' was not long in revealing the old flaws once more. The Austrian administration in Holstein almost immediately resumed its Federal or Augustenburg policy. The province was governed as if only in transition towards what it had so long desired - the position of a Little German Sovereign state, under the chief of its local nobility. While Prussia began to rule Schleswig with all its stern efficiency as a Prussian province, Austria, in her sphere, levied no taxes, put no restraints upon the Press, and even smiled at agitations in favour of Augustenburg. An Altona mass-meeting on January 23, I866, in the Augustenburg interest, helped to widen the breach. Bismarck, protesting in vain, declared that the two Powers were now no more in close relations, only ' as before the Danish War, neither better nor worse.' Even King William, who disliked the idea of a 'fratricidal' struggle, began to complain that it was impossible to work with Austria. More and more he

1 King William to the Duke of Coburg, April 4, 1866. 
now surrendered himself to the guidance of the Minister who had given up all thoughts of accommodation, and was bending his whole policy to the KleinDeutsch or Lesser German ideal, the rebuilding of the Fatherland without Austria, and through Austria's extrusion and defeat.

When at last, on March I6, Austria declared her intention of referring the whole question of the Elbe Duchies to the Federal Diet, 'in manifest violation of the Gastein Convention,' and of the original agreement of the two Powers, at the outbreak of the Danish War, all hope of agreement passed away. Conflict had practically begun.

Even before Gastein, Bismarck had advanced some way in the development of his anti-Hapsburg aims. For complete safety in an Austrian War he felt it was well to have not only his close understanding with Russia, but also the friendly neutrality of France, and if possible the armed alliance of Italy. Towards the latter, an obvious political resource in such conditions, he made some approach in the spring of I865; he resumed work at the former (already so profitable to Prussia in the Danish question and elsewhere) by a meeting with Louis Napoleon at Biarritz in September following.

What passed at Biarritz, 'passed without witnesses.' The French Emperor, acting without his ministers, indulged in much confidential talk with his dangerous guest-so much liked and trusted by him at this time. 'A really great man, free from affectation and full of esprit,' but full also of craft, caution, and daring, was dealing with a sick and weary adventurer, whose heart was better than his head, and whose entire 


\section{NINETEENTH CENTURY EUROPE}

conduct at this crisis marked him as the eminent ' unrecognized incapacity' of the Bismarckian epigram.

But, although one may well desire more precise knowledge of these momentous conversations, it is practically certain that Napoleon promised the neutrality of France in the event of Austro-Prussian war; that he agreed to the annexation of the Elbe Duchies to Prussia, in case of Prussian success (which, by the way, he did not at all expect); and that he listened without alarm or dissent to suggestions of German Federal reform on the basis of Prussian domination in North Germany-again assuming to himself an Austrian victory, or, at the least, a drawn battle. It is also beyond question that French compensation for neutrality was discussed. And, here again, it appears probable that while Bismarck refused to give up a single Prussian 'field or cabbage-garden,' and denied the possibility of surrendering anything German, he 'offered all kinds of things which did not belong to him,' especially suggesting French rewards in French-speaking territories-in other words, a French absorption of part of Walloon, or southeastern, Belgium.

It was easier to hypnotize Napoleon III. than to form an effective alliance with the Italians-yet by April 8, I866, that also had been effected. A PrussianItalian commercial treaty was first arranged, readily enough. Bavaria was induced to join in this, and to recognize the new Kingdom of Italy. Venetia, still under Austrian rule, was the special desire of Italian Nationalism. To gain Venetia, alliance with Prussia in an Austrian war was a good practical policy-and perhaps not to be rejected, if nothing better were at 
hand. Bismarck warned his Italian friends that, if he could not reckon on Italian aid, there might be no Austrian war after all. But the Italians were suspicious of Prussia. Having made alliance, they feared she might allow them to become hopelessly involved, and then make terms with Austria at their expense. Memories of 1859 were disquieting:-Vestigia terrent. On the other hand, Bismarck might fear, and did fear, that Italy and France would offer to Austria, as the price of Venetia, some Prussian lands.

And at the last moment this almost befel. On May 5, 1866, Austria did offer Venetia to Napoleon on behalf of Italy, on condition that France and Italy stood by and allowed her to compensate herself, at the expense of Prussia, in Silesia. But the new Italian premier and army-chief, General La Marmora, who had just signed the alliance with Berlin, though sharing the suspicions we have noticed, stood by his compact. $\mathrm{He}$ had more adequate views of the strength of the Prussian army than almost any other statesman of the time; he thought, and justly thought, that it was not Bismarck's purpose, or interest, to throw over the Italian friendship, and let the old German deadlock still go on ; and his secret treaty was expressly framed for the ending of that deadlock, which an Austrian reconciliation must needs perpetuate: 'If Prussia within three months [of April 8, I866] should take up arms for the reform of the Federal System of Germany, Italy would immediately attack Austria.'

For Bismarck was not disposed to open the decisive conflict with Vienna on the ground of SchleswigHolstein alone. He had already declared, earlier in the year, to the amusement, or amazement, of a cynical 


\section{I46 NINETEENTH CENTURY EUROPE}

world, the necessity for a reform of the German Federal system. He had appealed to all the minor German States for aid in giving to Germany, even in the teeth of Austrian resistance, a new and more effective organization. And on the morrow of the Italian alliance treaty he handed in at Frankfurt his proposals for the summoning of a German Parliament, to be elected by universal manhood suffrage (April 9, I866).

The furious Junker of 1848 had become a statesman, even in the 'Fifties; his new 'Liberal' plans were partly the result of secret intercourse with companions strange indeed to Conservative sentiment. Among these was the brilliant German-Jewish Socialist Ferdinand Lassalle. ${ }^{1}$ 'I will seek help,' said Bismarck, ' wherever I can get it.'

As events drifted steadily towards war, feeble and half-hearted proposals for a European Congress, to settle disputed matters, were advanced, only to be abandoned, and Louis Napoleon made a fresh move towards 'compensation' (May-June, I866). He would take Prussia's side with 300,000 men, he informed that Government, if France were compensated by the cession of Rhenish Prussia west of the Rhine. ${ }^{2}$ Thus might Prussia still save itself from defeat, if not from dismemberment. So far did the French Emperor foresee the issue of the coming struggle: so much excuse did he give for Carlyle's jeer at the 'hungry

1 One of the chief founders of Continental Socialism, born at Breslau, 1825, killed in a duel at Geneva, 1864 .

2I.e., including Aachen, Cologne, Bonn, Koblenz, with Trier and all the Moselle valley. 
sponging dogs,' whose opportunity was Germany's discord and Prussia's extremity.

While Bismarck, in early June, was evading this embarrassing proposal, Austria brought matters to a crisis by realizing her threat of March 16 . She summoned the Holstein Estates, and formally invited the Federal Diet to consider and judge the whole question of the Elbe Duchies (June 2). Prussia replied by declaring the Gastein Convention at an end, and by marching its troops into Holstein (June 7).

A state of war now practically existed. Austria demanded from the Frankfurt Diet the mobilization of the Federal armies against the Prussian peacedisturber, and by an almost unanimous vote the proposition was carried (June I4). Prussia declared the German Confederation at an end, and sent her ultimata to three of the Lesser States especially affected by the struggle-Hanover, Saxony and HesseKassel. In each case the anti-Prussian attitude was maintained. ${ }^{1}$

But although all the German states-except Weimar, and a few of the petty principalities of the north, such as the Mecklenburgs, surrounded by Prussian territory-ranged themselves on the Austrian side, the appearance of coalition was more formidable than the reality. The co-operation even of the Bavarians was to a great extent lukewarm and ineffective, if not practically disloyal.

1 Bismarck, in his half-bantering way, urged the heir of Hesse to hurry home and secure its neutrality. "If we were victorious the electorate would cease... The Hessian throne was surely worth a special train ...' B., ii. 26-7. 
148 NINETEENTH CENTURY EUROPE

The economic links of the Prussian Zollverein, which had for some time past bound together nearly all the German powers, ${ }^{1}$ were not wholly useless, even at this time. And the poverty and confusion of their military organization gave the Lesser States good excuses for weak defence and speedy cessation. The Saxons' vigorous resistance to the Bismarckian policy, and armies, was quite exceptional.

On the other side of the account, it must not be forgotten how disastrous was the Italians' participation in the war, and how slight the help they rendered their allies, apart from the great diversion of force they compelled Austria to make, in the first vital fortnight of the campaign.

The friends of Austria hoped that her ' 800,000 good troops' would have 'something to say in the matter,' but the reality of Austrian military strength was far below its reputation. Neither in generals, nor officers, nor men-nor yet in equipment and ' science '-were the Hapsburg armies now comparable to the Hohenzollern. The Vienna politicians, 'as in I859, had torn asunder the diplomatic bonds before the army chiefs were ready.'

In Moltke, that 'master-spirit of war,' Prussia possessed the first strategist ; in Albrecht von Roon, the best war minister; in Bismarck, the chief statesman, of the time. Although Lord Clyde, "after a close inspection,' had in these very days reported the Prussian troops to be just a good militia, the war showed them as perhaps 'the most formidable combatants ' of the Continent of Europe. ${ }^{2}$

1 Always, of course, with the exception of Austria.

2 Cf. Morley, Life of Gladstone, ii. 359. 
Austria had in Ludwig Benedek, 'the Protestant bourgeois,' her 'only possible ' army-chief, a character of rare nobility, but in conflict no match for his opponents. His modesty in vain tried to disclaim the dangerous honour. With prophetic despondency, he replied to Imperial insistence by expressing his "pain that Austria should not possess a 'better general.'

The Prussian invention of the breech-loading needle gun, which had been used, but not so much noticed, in the Danish war, gave a decided advantage, on the scientific side, over enemy troops still armed with the old muzzle-loaders. And with their superior energy, intelligence and tenacity, the Prussian officers and men, under Moltke's system of 'discretion,' clearly got the better of their opponents at most points. Benedek's cautious and leisurely tactics, and attempted rigidity of rule, failed against the speed and skill, the resource and helpfulness of his opponents. $\mathrm{He}$ could not cope with the initiative, the breadth of view, the flexibility, the care and foresight of Moltke's plans, and conduct.

Unless enemy numbers, or internal conflicts, bore her down, the Old Sand-box of Germany might yet surprise a Europe which mostly looked for her defeat.

And even in numbers Prussia did much to redress the adverse balance by the strenuousness of her measures, and the intensity of her levies. As in the War of Liberation, from a population of some six millions she had raised 270,000 soldiers, so now, in a War of Offence, from a population of nineteen millions she produced armies of 350,000 men. 'No other Government in Europe, except perhaps Russia, could have called upon its subjects for such a contribution 
without risking its existence.' 1 As in the French Republic of I792, as under the Empire of the first Napoleon, the whole resources of the State were mobilized for the purposes of a national struggle.

At the outbreak of the Seven Weeks War, the Austrian main army was concentrated at Olmütz in Moravia ; its objectives were Saxony, and the Prussian lands bordering on Saxony. Marching through the border mountains of Bohemia and Saxon Switzerland it would unite at Dresden, or elsewhere, with its Saxon allies.

On June I7 Benedek set his troops in motion, intending by leisurely marches to reach the Upper Elbe in about twelve days. A covering force guarded the mountains of easternmost Bohemia against Prussian attack from Silesia. ${ }^{2}$

But the rapidity and success of the enemy movements paralysed these plans.

Nearly the whole of the Prussian forces were thrown upon Saxony and Bohemia; yet an efficient though small force also operated in Central and South Germany against the chief allies of Austria in the 'Middle Zone.' On the side of Silesia, the Crown Princeafterwards the Emperor Frederick-with II5,000 men, was to force his way through the border mountains

1 When Napoleon III., after the Austro-Prussian War, 'tried to raise the forces of France to a war footing of $I$ in $70^{\prime}$ (and thus to equal (it was hoped) what the North German Confederation, even with the South German States, could throw against France), ' his own nominees in the Legislative Body, under pressure of public opinion, so weakened the scheme ' that the French effectives remained about the same as before 1866 .

2 The Prussian army chiefs at first feared the main Austrian attack in S.E. Silesia. 
into eastern Bohemia, except in case of a great enemy offensive on this side. On the side of Saxony, the army of the Right, 46,000 strong, and that of the Centre, 93,000 strong, under the famous 'Red Prince,' Frederick Charles, a nephew of King William's, were to overrun Saxony, enter northern Bohemia, and push on towards the south-east, to unite with the Crown Prince. The three armies were to concentrate about Gichin, north-west of Königgrätz.

Meantime a Prussian force of 48,000 men was to operate against Hanover, Hesse-Kassel, and Bavaria, the foes of the 'Corridor' and of the south-west. Moltke at first directed everything by telegraph from Berlin.

By the evening of June I8, when Benedek had but commenced his movements in Moravia, the Prussian troops had occupied three of the capital cities of their opponents-Dresden, Hanover, and Kassel. By the close of June 23 they had entered Bohemia from the north, with both their 'Saxon' armies, and the Silesian army of the Crown Prince had begun the passage of the east Bohemian mountains.

On Midsummer day fortune for a moment smiled upon the Austrian cause: the Italians, crossing the Mincio and attempting to invade Tirol, received at Custozza a check so severe, and so exaggerated in its effects, that the Hapsburg Government was soon able to treat all danger on this side as past, and to detach large forces for the main theatre of war. But ere these reinforcements could arrive, even on the Danube, King William had already won, as Moltke promised him, " not merely the battle, but the campaign.'

The Prussian armies in northern Bohemia, having 


\section{52 NINETEENTH CENTURY EUROPE}

threaded the defiles of Saxon Switzerland, and forced the practically undefended passes of the Erz Gebirge, ${ }^{1}$ pushed rapidly to the south-east, towards the Gichin rendezvous. When they occupied the town, on June 29, after a series of minor successes, the Hanoverian army had just been compelled to surrender at Langensalza (June 28), and the army of the Crown Prince had accomplished by three routes its passage of the Riesen Gebirge, ${ }^{2}$ had broken through all opposition, had entered Bohemia, and had even reached the uppermost valley of the Elbe (June 29-30). By the end of the month the Silesian outposts had joined hands with those of Frederick Charles, and all the Prussian armies of Bohemia were in touch.

So quick, smooth and successful had been the progress of his enemy, so many had been the petty reverses of his detached forces, that Benedek, in spite of Custozza, now began to despair. 'Sire, you must make peace at any price,' he telegraphed to Franz Josef, ' a catastrophe for the army is unavoidable.'

But his suggestion was rejected, and it was resolved to seek peace with Italy through Napoleon's intervention; to reinforce the Bohemian armies with troops from the Italian theatre ; and to retire Benedek's forces somewhat-but to make a resolute stand at the first good defensive position that could be found.

Such a position seemed to occur among the hills between the Bistritz and the Upper Elbe, centreing round the village of Chlum, ${ }^{3}$ having the hamlet of

1 'The Mountains of Ore,' forming the Saxon-Bohemian border.

2 'The Giant Mountains,' between part of Central Silesia and Bohemia, with the sources of the Elbe.

3 'High Ground.' 
Sadowa on its north-west side, and the fortress of Königgrätz, upon the upper Elbe, well in its rear, to the south-east. Here Benedek, delighted with the great possibilities of the region for resistance, carefully concentrated his 222,000 available men, laying stress on his reserves, and especially on the vast park of reserve artillery, massed upon the heights.

The Prussian armies immediately approachingthose of the old Centre and Right-were I20,000 strong: the Crown Prince, with the Silesian army of roo,000, was still from nine to thirteen miles to the east or north-east.

Somewhat recklessly, King William insisted on opening and pressing the attack through Sadowa, without this left wing, in the early morning of July 2, but the situation was saved for Prussia by the opportune arrival of the Crown Prince, after a heavy struggle with distance and bad roads, soon after noon. From the edge of the position the army of Silesia rapidly broke through to the key-position of Chlum, and the storm of these heights decided the day. The main Austrian forces, hopelessly exposed and broken in on their right flank, deprived of the central high ground of their position, raked by fire from that high ground, and violently pressed on two sides, were now in danger of being altogether cut off, as Moltke had planned.

To escape wholesale capture, Benedek was forced to fall back instantly on Königgrätz. Thanks to its admirable cavalry and artillery the bulk of the army escaped across the Elbe, and saved itself within the fortress. But it was severely shattered by material 


\section{54 NINETEENTH CENTURY E.UROPE}

loss, fatally by moral ; the 24,000 prisoners in Prussian hands were not such valuable spoils of the day of Sadowa as the ruinous discouragement and disorganization of Benedek's remaining troops. Pushing their advantage to the utmost, the Prussians occupied Prague on July Io, and Brünn two days later. Thus the head and heart of both Bohemia and Moravia had passed into their hands before the middle of the month. Leaving only a covering force to watch the fortress of Floritsdorf, the invaders thrust themselves between Benedek and Vienna, and even between Vienna and Hungary.

For in the last days of active fighting Prince Frederick Charles came right down upon the Danube, into the Marchfeld, that great plain, east of the capital, where Rudolf of Hapsburg, in 1278, and Napoleon in I809, had ' cast the iron dice.'

Meantime, in the west, the Bavarian forces in MidGermany guarding the valley of the Main were defeated at Kissingen and Aschaffenburg, and Frankfurt and Darmstadt were occupied (July IO-I7). A successful advance into the heart of Bavaria brought about the capture of Würzburg and Nuremberg, and the separation of the Bavarian 'Main-Army' from Munich and the bulk of their own people. When the truce was announced on July 26, South German participation in the war was almost at an end-thanks, largely, to the absence of any deep hostility to Prussia.

In refusing to make peace as best he might, Franz Joseph had asked Benedek, on July I, if a battle had yet taken place. Now that it had happened, and with such result, the Vienna Government at once invoked the mediation of France, and offered Venetia 
to Louis Napoleon-as a neutral patron of Italyif only the French Emperor could secure the withdrawal of Italy from the war. Napoleon responded by accepting Venetia, in this sense: by tendering his good offices, as a mediator, to all the combatants; and by proposing an armistice. Königgrätz had completed the shattering of his illusions, and the disarrangement of his plans, based on Austrian success, or a drawn struggle. But though surprised and disconcerted, he was not prepared wholly to give up the part of mediator, and tamely resign all the possibilities of intervention. And had he been willing, his position, his court, his ministers, his army-chiefs, would not have permitted it.

It is difficult to conceive, but important to recognize, that the Emperor of the French felt no fixed animosity against Prussia, no adequate alarm at her progress. Her friendship, even her alliance, he had desired. More than that, he felt a good deal of sympathy with German nationalism-for his kindly and generous nature was disposed to view all nations with a measure of candour and a desire for just dealing. What he had tried to secure for Italians and Rumanians, he was not disposed to deny to Germans.

Bismarck quickly secured from him the statement of a very moderate and forbearing policy. If Prussia would content herself with a limited degree of annexation, involving only about four millions of peopleand if she would permit the South German States, from Baden to Bavaria, to remain outside her system, he saw no vital objection to the new power she was acquiring, or to the new Empire she was creating. 
He did make some claims for compensation, or his Government made them in his name, but he felt no enthusiasm for this policy, and he probably spoke from his heart when repudiating it.

Yet though he was far from sharing the spirit of Thiers-here truly representative of the bulk of patriot feeling- Prussia must not be allowed to go further. The Unification of Germany is to be prevented at all costs '- he was not ready to defy it. Nor could he have done so with safety to his throne. Even as it was his easy tolerance and international generosity roused the deepest discontent among his people. 'The Peace of Westphalia condemned Germany to impotence' for many years. 'We can understand Germany seeking to raise herself from such a position, but that a French sovereign should look on and let her do so is incomprehensible.' 1

Bismarck, on his side, was equal to the occasion. Never did he shew a statesmanship more skilful than in the weeks of July and August, I866.

For one thing, he realized the danger of provoking by excessive demands a great coalition against Prussia, and so losing everything. For another, he perceived the possibility of preparing for reconciliation and co-operation with Austria, while enforcing all that was essential in his policy, by eliminating her German influence.

He now set before himself German, and not merely Prussian ambitions, though a decided increase of Prussian power was necessary to these larger schemes - 'German unity under Prussian leadership.' And ${ }^{1}$ Quoted in Sybel, Founding of German Empire, v. 4r 3. 
if through French alarm and jealousy, coming to reinforce the older difficulties, such general German unity was not for the moment attainable, he was still able to work for, and achieve, a lesser German Nation of the north.

For this, for a 'peace worth having,' he aimed, first, at gaining the utmost advantage from the campaign, while not refusing the French offers; next, at a treaty which 'pursued the German policy' with the least friction possible. By advancing to the utmost point consistent with Napoleon's friendship, and by stopping at that point; by insisting in negotiations on the essential, and waiving the non-essential, so alone would real and lasting gain be won. 'Now it is time,' he remarked, on the morrow of Königgrätz, ' to restore the old friendship with Austria.'

'We had (he remarks in his Reflections) to avoid wounding Austria too severely... and leaving behind in her any ... desire for revenge. We should reserve the possibility of becoming friends again with our adversary of the moment... I could see no future acceptable to us.... in case the Austrian monarchy were split up.'

Both as to Austria and the Lesser German States allied with Austria, Prussia's task (he repeated to the king and the military leaders, bent on exacting 'penalties') was not revenge. 'We were not there to administer retributive justice, but to pursue a policy... Our task was... German unity under the leadership of the King of Prussia' 1... 'If we do not think we have conquered the world (he writes home) we may get a peace that is worth while. But... 


\section{58 NINETEENTH CENTURY EUROPE}

my thankless task is to pour water into the foaming wine, and to remind people that we do not live alone in Europe, but with three neighbours.'

Austria, Bismarck had ascertained by mid-July, was willing to withdraw from the Germanic Confederation, and 'to recognize all arrangements Prussia might now make in North Germany (say, north of the Main), reserving the integrity of Saxony. It was understood that among these 'arrangements' would probably be the annexation, not only of the Elbe Duchies, but of the bulk of the Corridor of Middle States between the two great blocks of the Prussian kingdom.

While the French ambassador, who had eluded the military police, and suddenly appeared beside the bed of the Prussian Minister, on the night of July II, reassured him equally as to the moderation of France. 'Benedetti declared, as the basis of Napoleon's policy, that an augmentation of Prussia by four million people in North Germany, with the Main as the frontier on the south, would not entail French intervention.' 1

These conditions-Austrian and French-' contained (in Bismarck's view) all we wanted-a free hand in Germany,' and he fought strenuously, and at last successfully, to ensure acceptance.

But the struggle was hard. At a decisive Council of State the statesman declared his "conviction that peace must be concluded on the Austrian terms,' but he remained alone in his opinion. "The King supported the military majority.'

In subsequent discussions Bismarck's opposition so excited the King 'that discussion became imB., ii. 46. 
possible.' Believing that his opinion was rejected, the Minister left the room, with ideas of resignation, of rejoining his regiment, perhaps even of despair. 'The thought occurred to me whether it would not be better to fall out of the open window, which was four storeys high .... And I did not look round when I heard the door open, although I suspected that the person entering was the Crown Prince. I felt his hand on my shoulder while he said : "You know I was against this war... If you are now persuaded that our end is attained... I am ready to defend your opinion with my father." ... After a short half-hour he came back in the same calm, friendly mood... "It has been a difficult business, but my father has consented." '

For the moment 'Old William' grumbled at being 'left in the lurch' and 'compelled to bite a sour apple'-for ' at this time military impressions were dominant in his mind, and the need he felt of pursuing the dazzling course of victory.' 1 But when he had time to attend to 'political considerations,' he was able to feel differently. Prussia (and William was ever a Prussian, before all else) now acquired what she had lacked, despite all the gains of the Vienna Settlement - the frontiers of a sound state.' By the Preliminaries of Nikolsburg and the Peace of Prague, she absorbed nearly all the corridor which divided her provinces. The Kingdom of Hanover, the Electorate of Hesse, the Principality of Nassau, the Duchies of Schleswig-Holstein, the Free City of Frankfurt, and little Hesse-Homburg-representing (in the first four cases) areas roughly equivalent to Wales, Devon,

$$
1 \text { B., ii. 51-2. }
$$


Somerset, and Yorkshire-were absolutely incorporated. The Prussian eagle could now 'dip one wing in the Moselle, and the other in the Niemen' with greater safety. The controversies of the Danish war were ended by that complete annexation of the Duchies which Bismarck had always ' kept before his eyes.' The pan-German character of the Prussian State, first made evident by the assignments of Vienna, half a century earlier, received a notable emphasis. And a new German Empire, under the headship of Prussia, was now in reality created. It was to be called The North German Confederation (Nord-Deutsche Bund). It was to include all Germany north of the Main river and the northern frontiers of Bavaria. Thus it comprised the Kingdom of Saxony, the Thuringian States, and the northern part of Hesse-Darmstadt. Of this Confederacy, which formed a first draft of the Empire of $187 \mathrm{I}$, the King of Prussia was President.

Austria was severed from all political connection with the rest of that Germany over which she had so long and so ineffectively presided. But here she lost no territory; all the Hapsburg hereditary lands she retained. By her cession of Venetia she also ceased to be an Italian power-seven years before, she had abdicated her dominant position in Italy.

To meet the objections of French policy ; to gratify Louis Napoleon with an appearance of diplomatic success; and to prepare more effectively by present caution for future strokes of daring, the states of South Germany, between the Main and the Austrian frontiers -Bavaria, Württemberg, Baden, and the southern part of Hesse-Darmstadt-were left under a special arrangement. 
Independent of the new Prussia-Germany of the North, as of Austria, they were not absolutely debarred from entering into some kind of bond or understanding with the former. But this latter result was apparently unexpected by the French diplomacy, which made so vital a point of the freedom of the South. In statements issued in various forms (as, for instance, on September I6, I866) Napoleon boasted, or suggested, that he had broken Germany into two (or, counting Austria, into three) parts, and laid the foundation of a South German League, which should look to France as its protector. At the same time, he deprecated French suspicion and jealousy of Prussia, applauded the inevitable and welcome progress of the great principle of nationality, and with true nobility of language appealed against 'the great illusion.' Political thought should rise above the narrow prejudices of a past age. 'The Emperor does not believe that the prosperity of one country depends upon the weakening of its neighbours, and sees no real Balance of Power save in the satisfied wishes of the nations of Europe ... Prussia enlarged-free henceforth in all solidarity-assures the independence of Germany.' France should take no umbrage at that. 'The national sentiment of Germany being satisfied, her enmities disappear.' ... 'By what reaction of past upon future should one see enemies of France in nations freed from a past hostile to France? An irresistible power (can it be regretted ?) impels peoples to unite themselves in great masses, causing minor states to disappear. France's part is to cement a union between all the Powers that maintain authority and favour progress.' 1

${ }^{1}$ French Imperial manifesto of September $16,1866$. N.C.E. 
Unfortunately for himself, for France, and for Europe, Louis Napoleon, from the day of Sadowa, felt obliged to advance compensation-proposals, one after another, which all ended in failure; which embittered French feeling against Germany, and German feeling against French; and which apparently made Bismarck; what he had not hitherto completely become, the determined foe of the French Empire. At the very time when Bavaria or Darmstadt was invoking French mediation in its negotiations with victorious Prussia, French diplomacy was endeavouring to arrange with Prussia for French compensation in Bavarian and Hessian territory west of the Rhine (July 25-August 7, I866). Especially was this claim pressed in regard to the key-fortress of Mainz, the chief Hessian town. "Do you demand Mainz under threat of war'? Bismarck claims to have said at last to Benedetti in these midsummer days of I866. 'Yes.' 'Then war you shall have.' Such demands played into the hands of the Prussian Minister. He took care, at the right moment, to inform the South German governments of the French proposals. By a series of secret treaties, beginning with Württemberg, he gradually (before the end of I866) bound these states to Prussia in offensive and defensive alliance under Prussian leadership. And his defiance found France imperfectly prepared, and Napoleon entirely unwilling, to enter on so fierce and dangerous a struggle. It was all a misunderstanding, the French Emperor declared, in which he had been entangled by his Foreign Minister, during his illness (August II, I866).

Thus, thanks to the Bismarckian policy and thanks to the mistakes of others, King William's longing for 


\section{THE UNITY OF GERMANY 163}

Prussian 'supremacy over all Germany' 1 as a result of the Seven Weeks War, had advanced a long way towards fulfilment. The new German Empire had been not only founded, but also extended, in this year of great decisions.

1 This 'Suprematie über ganz Deutschland' the King wished to make a formal condition of the ptace with Austria. At that time such a demand, pressed to the full, would have meant immediate war with France. Cf. Sybel, Begriindung, v. I70. 
Part III. From the Austrian to the French War, I866-70

The Seven Weeks War, and the resulting settlement in foreign affairs, began a vital change of political atmosphere and life in German lands. The Bismarckian policy in home affairs completed the change.

The Minister-President was at last in a fair way to realize those hopes of his which had seemed so absurd - ' of becoming the most popular man in his country.' He might now, perhaps, have defied the Liberal majority in the Prussian Diet. Events had convicted them, in the ordinary sense, of political error. They had opposed the expansion of the army. In the teeth of their opposition the army had been expanded Now the army had become the instrument of a triumph, astonishing in its rapidity and completeness.

But instead of carrying this kind of victory into domestic affairs, the Bismarckian Government asked for forgiveness. An act of indemnity was requested for illegal or semi-illegal action, extending over years, but undertaken, it was pleaded, in the highest interests of the State, and at last vindicated by success.

It took some persuasion to bring King William to this point (as to the point of biting ' the sour apple' of the Peace of Prague). But he now fully recognised in the judgment of his Minister the higher reason which he wished to obey, and he announced the concession in a speech which won him the hearts of most opponents. By a great majority the indemnity was 
granted; practically the Government was thanked for saving the country in spite of itself. A new era had commenced ; a barren struggle had ended. Rulers and people settled to a new harmony of thought and action.

The Government won further popularity, not undeserved, by the constitution which Bismarck devised for the new Germany of the North.

To the amazement of Liberals, the red reactionary, 'only to be utilised where the bayonet governs unrestricted,' carried out in action the proposals of Federal Reform which he had made at Frankfurt before the war. Most men had imagined these to be a sort of grim Bismarckian jest, a piece of monstrous banter, or at best a politician's dodge. Now they saw these 'mockeries' carried into effect. The German people, so far as it was now regrouped in the Confederation of the North, was called on to elect, by manhood suffrage, a Federal Parliament.

Not only did this help to conciliate the territories now annexed to Prussia, or put under her leadership, from Saxony to Frankfurt, but it produced an effect almost revolutionary upon the old Liberal thought and the old Liberal party.

Here, and now, began the National Liberals. This great section of the Progressives, while still proclaiming their loyalty to many Liberal ideas, now practically declared their acceptance of Bismarckian leadership in foreign affairs and in general German policy. As men in later days said in Britain: 'My politics are Gladstone,' so in I866 the new Teutonic creed rested on personal allegiance-' Ich bin bismarckisch.' Almost 
immediately National Liberals began to replace Conservatives in the Cabinet, and for twelve years they remained the firmest Parliamentary support of the Chancellor's system.

The constitution of the new North German Bund was in all vital respects a forecast of that which Bismarck provided for the completed Empire five years later. In summarizing the former, one sketches the latter. To the Kaiser or Emperor of 187 I answered the President-das Präsidium-of $\mathrm{I} 866$; in both cases the Headship was annexed to the Crown of Prussia, with similar rights and duties. To the Reichs-Kanzler or Imperial Chancellor of I87I answered the BundesKanzler or Federal Chancellor of I866, with much the same duties and authority-in both cases Bismarck himself. To the Upper and Lower Houses of Representatives, the Senate or Bundesrath, and the National Assembly or Reichstag, of I87I, answered the Houses of $\mathrm{I866}$, with identical names, and practically identical powers, limitations, and franchises. Only in 1866 these Houses represented twenty-two, or rather twentyone and a half, in I87I twenty-five, German states. The essential difference, here as elsewhere, was the addition of the South-German zone-Bavaria, Württemberg, Baden, Hesse-Darmstadt.

The military system of the Federation was naturally more completely Prussianized (especially in peace time) than that of the Empire, which included such a weighty non-Prussian element as Bavaria; yet in the main the result was similar. In 1866 the armies of North Germany, in I87I the armies of all Germany (Austria, of course, excluded), had ' become honourably 
Prussian,' as it seemed to the Scottish Treitschke. Carlyle saw his ideal in action. The universal compulsory military service of Scharnhorst and Roon extended in 1866 to the whole Bund, became in $187 \mathrm{I}$ the law of the entire Reich.

To the victor the Seven Weeks War brought intoxicating success ; to the vanquished it brought a measure of statesmanship and settlement. The Austrian German and the Hungarian Magyar ended their quarrels, and began a new partnership-in other words, the Hapsburgs granted a very complete Home Rule to the most important, intelligent, and turbulent of their vassal peoples. Vienna no longer struggled to hold down Buda-Pest: both united to make the Dual Monarchy, both agreed to hold down the Slavic dangers which menaced both.

Even before the Seven Weeks War this solution was in a fair way to acceptance, when internal negotiations were suspended by external conflict. After the Peace, 'conversations' were resumed, and the complete Ausgleich or Compromise was arrived at early in 1867 .

By this, the Magyar element in the Hapsburg State was practically admitted to a partnership with the Germanic, hitherto dominant. The Empire was divided into two halves-one part, mainly in the west, but including Austrian Poland, now appeared as The Lands of the Austrian Crown; the other part was now the reconstituted Kingdom of Hungary, The Lands of the Hungarian Crown. In each of the divisions the Hapsburg sovereign reigned-but now only in the Austrian Crown Lands as Emperor; in Hungary he was Constitutional King, the wearer of the Crown 


\section{I68 NINETEENTH CENTURY EUROPE}

of St. Stephen. A separate Parliament was established for each half of the State. Common Ministries were maintained for war, finance, and foreign affairs. The budget for the Common Ministries, and the settlement of disputed points, were to be arranged by two Delegations, one from the Austrian, one from the Magyar, side. And the old Magyar possessions (in certain ages) of Croatia in the south-west, and of Transylvania in the east, were to be 'restored' to the renewed Hungarian Kingdom. The Ausgleich was sealed by the coronation of Francis Joseph as Apostolic King of Hungary on June 8, 1867. And from this time till the close of the recent world-war it is by this Ausgleich that Austria-Hungary (or 'Hungary-Austria') has been governed.

Francis Deák, the Magyar, after Bismarck and Cavour one of the leading figures in the recent political life of Europe, was the chief, though not the only, begetter of this Compromise. The Hapsburg sovereign himself, so long esteemed, till the wild follies of I9r4, as a Solomon among sovereigns; and Count Beust (once Saxon Minister for Foreign Affairs, now and till I87I Austrian Chancellor, steady rival of Bismarck, and opponent of Prussia) may also claim a share in establishing this remarkable experiment. By the Ausgleich, Slavs, Rumanians and Italians were still kept in a measure of subjection; the aspirations of Bohemians and Poles were baffled; a Federal solution, perhaps the best possible for the Monarchy, was prevented; and Hungary escaped with too slight a share of the common financial burdens, and with an excessive power of domination over non-Magyar races throughout Hungarian lands. 
In these years, moreover (1867-70), there are momentous happenings outside Europe which affect Europe very nearly.

In the first place, it is now that the Russian conquest of West Central Asia is really decided.

The treaty of November, I868, marked the completion of Russian advance to the banks of the Oxus, and almost to the foot of the mighty mountain wall which parted India and 'Turkistan.' The Khanates of Bukhara and Kokand-all that was left of them -now became feudatory states of the Tsardom; large portions of both were annexed; the tension between London and St. Petersburg was markedly and naturally emphasized.

Again, the Japanese Revolution, the remarkable transformation by which the ancient Island Power of the Far East became a modern state after the European pattern, begins its full operation in I868, on the eve of the Franco-German War. A nation till then armed with bows and arrows and quilted armour, with no ships but junks, and without machinery, now commenced its imitation of the material civilization of Europe, and within forty years it was ready to fight the European with his own weapons.

Once more, the close of the American Civil War, and the reunion of the United States, with its vast forces of citizen soldiers trained in the struggle of north and south (I86I-65), compelled the abandonment of the French experiment in Mexico (I867). Here Napoleon III. had hoped to create a new LatinAmerican Monarchy, dependent on France, and perhaps 
destined to restore to the French nation a sort of colonial empire in the New World, replacing that which the eighteenth century had lost. But the Republic of the North no sooner resumed its place among the great powers of the world than it reiterated the Monroe Doctrine, "That the American Continents are henceforth not to be considered as subjects for colonization by any European power...,' and dissipated the dreams of the imperial visionary. The French Government wisely shrank from a conflict, at so great a distance, with a friend so old, so tried, and so useful, an opponent so powerful. None the less, the Mexican retreat, involving the tragic fate of Napoleon's client, Maximilian of Austria, was another blow to the prestige of the Second Empire.

We may now return to the central subject of FrancoGerman relations at this time.

The French intervention in I866, ineffective and nugatory as it proved, seems to have made Bismarck a convinced enemy. He now considered that after the struggle with Austria a war with France lay 'in the sequence of history.' 1 He made less effort to maintain cordial relations with the Napoleonic Government. He baulked all negotiations for French compensation on German soil. He no longer avoided conflict. And, with the co-operation of French determination 'at all costs' to prevent the future Unification of Germany, the conflict was realised. The Continental history, therefore, of these years, ${ }^{2}$ is largely one of drift towards a decisive struggle between two of the chief races of

\footnotetext{
' 'In der historischen Consequenz' B. ii. 56 (ii. 41, Eng. trans.).

2 i 867-70.
} 
Europe, so constantly at enmity throughout the modern centuries.

Although negotiations for French compensation, at the expense of German territory, whether Prussian, Hessian, or Bavarian, had failed in I866, Louis Napoleon renewed his efforts, in the following spring, in a somewhat different direction. He now hoped to acquire the Grand Duchy of Luxemburg, which, although nominally part of the old German Federation destroyed by the Seven Weeks War; although included in the Prussian-German Zollverein; and although admitting a partly Prussian garrison in its capital (which ranked as a German Federal fortress), was ruled by the King of Holland; was usually considered as Netherland rather than German territory; and had not been brought within the new Federation of the North.

The King of Holland was approached, and consented to the sale of his rights to France, if this could be effected without offence to other powers.

Bismarck was also approached, and at first appeared friendly to the project. He declined to give a formal 'agreement,' but disclaimed any wish to 'interfere.' But on the first publication of the design such a storm arose of German Nationalist wrath that the Prussian statesman notified France of the ' necessary opposition' of his Government.

The position was complicated, at this very time, by the renewed clash of that more general and dangerous rivalry which underlay all details. On March I4, I867, the 'old man eloquent,' Adolphe Thiers, so long one of the leaders of French politics and thought, now once more ' giving voice to the sentiment of all France,' 
declared in a famous speech that Prussia must not be allowed to go further, and that the Unification of Germany must at all costs be prevented.

'We recognize the people of Saxony and Baden and Hesse as nations, and we will not permit them to be welded into a German nation under Prussian hegemony.'

Bismarck's reply was to publish (also at the height of the Luxemburg controversy) the secret treaties of alliance between Prussia and the South German States (March I9). And after this the King of the Netherlands naturally refused to agree to the sale of Luxemburg, without the express consent of the Great Powers, and especially of Prussia.

Extreme exasperation resulted in France, and an immediate war would have been the popular course. 'Bismarck,' said Napoleon himself, ' has tried to dupe me.' 'Bismarck,' exclaimed the French Foreign Minister, 'has tried to lure us into a position without retreat, and to outrage us before Europe.' But once more the failing Emperor postponed the evil day. 'We have no desire to interfere in the domestic affairs of Germany.'

All he could now do was to procure the withdrawal of the Prussian contingent from Luxemburg city, the dismantling of the fortress, and the definition of the Duchy as neutral territory, under a guarantee of the Powers. And these were the results of a London Conference held in May, I867 (May 7-II), which settled the status of the little principality for many years.

Thus faced by an imminent danger of mortal conflict, both the French Empire and the new Prussia-Germany watched, prepared, negotiated. Louis Napoleon's 
diplomacy was now chiefly directed to forming alliances with Austria-Hungary and with Italy-Bismarck's to maintaining his Russian entente, practically a defensive alliance; to averting the ill-will of Austria; to conciliating Italy. Neither from Vienna, nor from Florence, could he hope just yet for definite co-operation against France.

Count Beust, now directing Austrian policy, would have hailed with rapture a definite anti-Prussian League, but two considerations gave pause. One was the attitude of Hungary. As one of the Magyar leaders put it: "Hungary has no interest in restoring Austria's German connection. Hungary is far better off without this.'

The other hindrance was Russia. The Tsar and his Ministers, still governed so much by anti-Austrian feeling, tied to Prussia by the Bismarckian policy, and hoping through Prussian success to achieve the cancelling of the Black Sea clauses of the Treaty of Paris, was ready to attack the Hapsburg State, if this State, in alliance with France, threw herself upon. the 'Prussian friend.'

The Prussian alliance of 1866 with the Italian kingdom had ended with no more cordiality than the French alliance of 1859 . The Italians smarted under Prussian criticisms of ineffectiveness in the campaign, under charges of disloyalty, and under the failure to acquire the Trentino. There existed a certain amount of gratitude to France and of cordial feeling for the ' Sister Latin Nation.' And Victor Emmanuel, though sorely vexed and angered by French policy at times, was emphatically pro-French, just as Mazzini was 


\section{NINETEENTH CENTURY EUROPE}

almost pro-Prussian in his suspicion of Bonapartism. When at the end of 1866 Napoleon at last withdrew the French troops from Rome, things appeared to point once more towards the renewal of intimate friendship and alliance.

But in 1867 the fair prospect was again clouded. The Garibaldian attempt to seize the city of the Popes, secretly encouraged by the Italian Premier, produced a return of the French defenders to the Papal territory, and with the help of these allies the Papal troops defeated the 'Red Shirts' at Mentana (November 3, r867).

'The chassepots have done wonders,' wrote a French general in delight at the efficiency of his new rifle; but the publication of this tribute was scarcely wise.

Still more mischievous was the declaration, at the same time, of the French Minister-President that the Italian Nationalists must never be allowed to seize Rome. 'Never will France tolerate such an outrage on its honour and dignity.' Napoleon could not well defy the Church party at home, but France owed little thanks to that party in this crisis.

Thus, just as Russia and Hungary baulked French plans of Austrian alliance, so the Papal question stopped the re-formation of Franco-Italian alliance. And just as most of France and of Europe believed in I866 that Austria would beat Prussia, ${ }^{1}$ so after I866 the same public opinion believed that France would defeat the new Prussia-Germany. 'About the only thing Bismarck thoroughly dreads,' wrote even Morier, 'is a passage of arms with France.' It is easy to be wise after the event.

${ }^{1}$ B. ii. 95 (ii. 82, Eng. trans.): 
In steering through the troubled waters of this time, Bismarck's chief reliance was upon the Russian friendship. Beyond doubt he had thoroughly assured the Tsar of Prussian benevolence towards the revision of the Treaty of Paris. To accomplish such revision (Russian policy calculated) it would probably be necessary that France or Britain should be crippled or diverted; neither, without the other, would be likely to insist on the Black Sea clauses.

More and more the Chancellor seems to have thought the French war inevitable and desirable. Complete German unity, the crown of his work, could not be realized without French defeat. With Napoleon III. it might be possible to live in peace and yet to finish Germanic Federation; the Emperor would doubtless soon reconcile himself to the last steps, as he had to the earlier. But his statesmen, his Parliament, his press and his people, would never allow this. 'We will not permit a German nation to be welded together under Prussian hegemony.'

The air was full of hostile rumours. Mazzini in midNovember, I867, warned Bismarck that Napoleon was ' going to attack' Prussia, and had secured the aid of Victor Emmanuel by leaving Rome to the Italian Kingdom. With the aid of the Revolution, Mazzini offered to defeat this plan-which as a definite alliance certainly existed rather in his own brain than in fact. And responsible German statesmen told Robert Morier of Napoleonic proposals of definite Franco-Austrian alliance (before the end of November, I867) with the well-defined objects of obtaining the left bank of the Rhine for France, and of annexing to Austria the Southern States of Germany. 


\section{Part IV.-The Franco-German War, 1870-7I}

But it was the explosion of an unexpected and a Bismarckian mine which finally caused the war.

The Spanish throne fell vacant in the autumn of I868, and it became necessary to find an 'external candidate.' Several personages were suggested, considered, and sounded, in vain. But at last a possibility was found in Prince Leopold, a member of the junior and Roman Catholic branch of the Hohenzollerns, whose father, Prince Charles Antony, had been the Prussian Minister-President 'of the New Era' in I859, and had been one of the earliest and strongest advocates of Bismarck for the same office. His elder brother, Charles, had become Prince of Rumania in I866, and Bismarck's conspicuous success in this nomination was certainly one reason for the present venture. But Leopold was also connected with the House of Bonaparte. 'I had not the slightest doubt' (writes Bismarck) 'that the grandson of the Murats, acceptable as he was at the French Court, would secure the goodwill of France towards his country.' Others, such as Charles of Rumania, thought differently. ${ }^{1}$

There was a certain amount of coming and going, but no decision, in I869. Things moved faster in the following spring.

1 Even back in December, 1868, he notes in his diary that France would undoubtedly object (December 9). Bismarck's optimism is in the Gedanken, ii. 102 (ii. 89, in Eng. trans.). 
On March 15, I870, an important meeting was held at Berlin, under the presidency of King William, which was partly perhaps a Hohenzollern family conclave, and partly an informal Council of State, to discuss the offer of the Spanish Crown. ${ }^{1}$

Bismarck pressed for its acceptance on political grounds, and the Council unanimously agreed. But Prince Leopold, after much wavering, declined. ${ }^{2}$ Two months later (May I870), writes Charles Antony: - Bismarck is very discontented with the failure of the Spanish combination. $\mathrm{He}$ is not wrong. Still the matter is not entirely given up.' 3 This was true enough, and on July 3 the world was startled by the announcement of Leopold's acceptance of the Spanish Crown, subject to the consent of Cortés. But the goodwill of France was not secured. French Nationalism, which had cordially disliked the Hohenzollern at Bucarest, trembled with anger and alarm at the prospect of a Hohenzollern at Madrid. In May I869 on the first rumour of such a thing, the French Government had already expressed its displeasure. On July 6, I870, the Duc de Gramont, as Foreign Minister, after a Ministerial Council presided over by the Emperor himself, declared in the French Chamber the attitude of the Imperial Government. In the event of persistence in this candidature, France 'would know how to do its duty without hesitation and without weakness.'

1 Bismarck apparently denies that this was a formal council (ii. I02; ii. 89, Eng. trans.). In any case, there were present, besides the King of Prussia, the Crown Prince, Bismarck himself, Moltke, Roon, Prince Charles Antony, and three others. Letter of Charles Antony to his son Charles of Rumania, March 20, 1870.

2 Before March 20.

"Memoirs of King of Rumania, p. 95. 
Yet in London, on the previous day, July $5, \mathrm{Mr}$. Hammond, "the experienced Under-Secretary for Foreign Affairs,' had assured ' his new chief, Earl Granville, that, except for some Greek brigandage, he had never, during his long experience, known so great a lull .... and that he was not aware of any important question" with which Lord Granville ' would have to deal.'

Meantime Count Benedetti at Berlin was demanding the withdrawal of the Hohenzollern. He got but little satisfaction from Bismarck (who was away in the country recuperating) or from his subordinates, who denied that Prussia had anything to withdraw. 'It was not her affair ...' Officially the Prussian Government knew nothing of the matter. It touched the King alone, and only touched him as head of the family. Benedetti, therefore, went off to try King William himself, who was drinking the waters at Ems, near Koblenz, and here met with better fortune. The King, although protesting that he could not and would not force his young relative to withdraw, shewed himself clearly favourable to a peaceful solution.

British and Italian diplomacy were also working for a settlement on the basis of concession, and on July I2 the candidature was formally renounced by Leopold. But Napoleon himself was ill, and the direction of French policy was now practically in the hands of a mar almost as desirous, and of a military party quite as desirous, of war as Bismarck himself had become.

Benedetti was accordingly instructed by Gramont to demand Prussian guarantees that the Spanish candidature of the Hohenzollerns should never be 
renewed. And a draft letter of apology was sketched out by the same Gramont for King William to send to the French Emperor. The 'North German' Ambassador in Paris, Baron Werther, humbly accepted this draft, and forwarded the apology to his sovereign; one is hardly surprised to find him a few days later ' severely censured.'

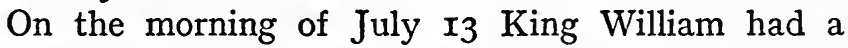
momentous conversation with Benedetti at Ems.

'He spoke to me on the promenade,' wrote the King, 'to demand from me, finally in a very importunate manner'- 'almost impertinently,' William told Queen Augusta- 'that I bound myself never again to give my consent if the Hohenzollerns should renew their candidature. I refused at last somewhat sternly, as it is neither right nor possible to undertake engagements of this kind à tout jamais ...'

William promised, however, to communicate personally to the ambassador the expected renunciation, as soon as it should arrive. In the course of the day arrived Gramont's draft-apology for the Prussian monarch to read, learn, inwardly digest-and sign. It was followed, a little later, by the formal withdrawal of Leopold's Spanish candidature. Deeply insulted, the King now merely apprized Benedetti of the Spanish settlement by a curt and cold message, without personal interview. To the ambassador's fresh demands of future guarantees, he merely replied that he approved of the renunciation, but could do no more. He had nothing further to say.

The incident, without any reference to Gramont's apology-form, the most unpleasant of all the details, was communicated to Bismarck in the earlier and 
complete form of the 'Ems Telegram.' 'His Majesty leaves it to your Excellency,' the message concluded, ' whether Benedetti's fresh demand, and its rejection, should not be at once communicated both to our Ambassadors and to the Press.'

The Chancellor had Roon and Moltke dining with him that evening of the I3th. All were greatly depressed by the King's weak complaisance, as they viewed it, in the whole negotiation. Bismarck himself talked of resignation.

'Between six and seven' the telegram arrived, was decyphered, and brought to Bismarck. 'I read it to my guests, whose dejection was so great that they turned away from food and drink.'

The Chancellor lingered upon the authorization to publish the King's refusal to these new demands. He questioned Moltke about the Prussian readiness for war; received the reply that 'a rapid outbreak' would be " on the whole more favourable to us than delay'; reduced the telegram, 'but without adding or altering'; and read out the shortened version.

'Now it has a different ring,' commented Moltke, ' it sounded before like a parley: now it is like a flourish in answer to a challenge.... If. I may but live to lead our armies in such a war. ... Bismarck then gave his view that the telegram when published would probably be sufficient to push matters over the brink. It would act 'as a red rag upon the Gallic bull. Fight we must, if we are not to play the part of vanquished without a battle.' ${ }^{1}$ But success, he added, was largely bound up with the impression created at, and by, the outbreak of war. 'It is important that

1B. ii. I08-113 (95-100 E.T.). 
we should be the party attacked, and this Gallic pride and touchiness will make us, if we announce... that we fearlessly meet the ... threats of France.'

Bismarck's forecast was justified. On the next day, July I4, the anniversary of the national fête, Paris learnt of the new developments. The Ems telegram, published in the North German press, and at every North German or Prussian embassy, produced a maddening effect, especially in the French capital. It is difficult to believe that the original and longer form of the message, with the angry phrases of King William, omitted in the condensed Bismarckian publication, would have had a more soothing effect. Three cabinet councils were held, between sunrise and midnight ; and at the last, despite all the hesitancy of the Emperor, war was decided. 'Sire,' burst out Gramont, ' if you mention a congress again' (Napoleon was still clinging to his panacea of a conference of Great Powers) 'I throw my resignation at your feet.' 1 'Guarantees we cannot bring you' (it was announced to a joyful senate and chamber) 'but we bring you war.' As Lord Loftus reported, and as Ollivier confessed, the agitation was so great that no peace government could survive. With only ten dissentients the French legislative body granted the supplies demanded by government.

If in France hopes were still entertained that the South Germans might stand aside, such hopes were immediately falsified: 'All Germany fought for Prussia.' Thus the warring nations were roughly

1 Yet Gramont himself, earlier in this day, had proposed a congress, for the ratification of French views on vacant thrones. 
equalized in numbers-some thirty-eight millions on each side. But they were equal in nothing else. 'The elements of victory and defeat were present in the previous condition of the belligerent states.' Prussia was far better prepared for the struggle. As her international policy for eight years, if not for thirteen, had been the most skilful, though hardly the most scrupulous in Europe, and now gained its most conspicuous and tragic victories, so her military system and leadership now maintained and developed that old reputation which had been so recently revived in the Danish and Austrian campaigns. And just as even the first weeks of war revealed the readiness and thoroughness of Prussian organization, so the same time disclosed French unpreparedness. Thiers had ' laboured hard ' (he told Earl Granville in September) ' to persuade the Emperor that France was not ready.' .This pessimism proved more accurate than the confidence which drowned all warning voices: "The soldiers of Jena are ready.... All is in order, to the last button on the gaiters. ... We are archiprêts.'

Even Moltke had not supposed it to be possible to prevent a French invasion of Southern Germany, and his original plans were based on this natural diffidence. ' It is a delusion to imagine that a plan of campaign can be laid down far ahead and fulfilled with exactitude. The first collision creates a new situation.' But instead of crossing the Rhine at Maxau, and forcing the defiles of the Black Forest, the French made no forward movement of any importance beyond their frontiers. Even a raid into Baden was not attempted. For the troops ' marched out of quarters, insufficiently equipped 
... many without the most necessary articles . . often with no artillery, baggage, ambulance, or magazines ... and without a proper supply of officers.' The railway provision was extremely inadequate, and the intelligence bad. In expectation of immediate advance into Germany, the fortresses had been neglected, and while the staff was well provided with maps of German territory, it was scantily supplied with plans of those French border-regions which would soon become the theatre of war. ${ }^{1}$ At the end of the first fortnight, by August 2, the German mobilization was complete; King William had arrived at Mainz, to take supreme command; and the invasion of France by 450,000 enemies was commencing.

The invaders attacked in three main bodies. First was the army of General Steinmetz, smallest in numbers (slightly over 60,000 ) and farthest to the north-west, moving up the Moselle valley, from Koblenz to Trier, and then up the Saar across the border of Lorraine. The second army, the army of the centre, was that of Frederick Charles, 'the Red Prince '; its 200,000 men moved from Mainz through the Bavarian Palatinatealso towards the valley of the Saar and Lorraine. The third army, that lying most to the south and southeast, composed mainly of South Germans, was under the Crown Prince of Prussia. It moved (180,000 strong) towards northern Alsace, and the conquest of that province was its first achievement.

On August 4 this third army began the main operations of the war by its onslaught upon the Alsatian border at Weissenburg (famous in the early campaigns

$$
{ }^{2} \text { Moltke, F.G. War, pp. 4-6, II (E. T. I891). }
$$


of the French Revolution). The French positions were carried, and the Germans entered Alsace. On the next day the first and second armies crossed the Saar, and reached the northern border of Lorraine (August 5). And on the 6th two more successes brought the invaders far over the French frontiers. On one side the Crown Prince at Wörth dealt (at a heavy cost) a deadly blow. 'Alsace was lost at Wörth,' for the covering force under Marshal Macmahon, here broken and demoralized, and vigorously pursued, made no stand in the Rhine province, nor even in the mountain barrier of the Vosges, but fell back, from point to point, right into Champagne. Only at the great military camp of Châlons-on-the-Marne did it rally. Strassburg, thus uncovered, was immediately invested (August II).

On the other side, upon the very day of Wörth (August 6), hot-headed old Steinmetz,' "waster of men,' forced the French positions at Spicheren on the northern edge of Lorraine, and the defenders fell back on the fortress of Metz. Though partially concealed from the public for a time, these first disasters soon produced a government crisis in Paris. The dynasty was shaken : its complete fall was for a few days postponed. But while the Empress was made Regent, the Emperor himself resigned his own supreme army-command to Marshal Bazaine, and the Ollivier Ministry resigned, together with that Marshal Leboeuf, who had so glibly urged the war, promised victory, and applauded his own perfect preparations.

The German plan of campaign now developed towards the isolation, encirclement, and destruction of the two main French armies-that of Châlons, as we 
may now call it, and that of Metz-and this plan was accomplished in the battle of Sedan and in the surrender of Bazaine. The French, as events shaped themselves, hastened upon destruction. Their object, after Wörth and Spicheren, was naturally to unite their forces, and if possible, with reinforcements, to make a firm stand, and check the Germans-otherwise, to fall back towards Paris, rallying all the forces of national defence to guard the capital.

But meantime Moltke's offensive progressed rapidly. The army of Bazaine was cut off in the Metz region by a successful enemy thrust to the south, south-west, and west of the fortress ; and a series of battles, ending with, and culminating in, that of Gravelotte (August I8), locked up the best army of France in the great stronghold of Lorraine, with wholly insufficient supplies. Thereupon the Châlons army was set in motion, for the extrication of Bazaine's defeated, dispirited, beleaguered, but still most valuable force. The Germans being especially strong to the south and south-west of Metz, weak as yet to the north, the scheme was to effect union and relief, on that side, by a detour. If the foe could not be thoroughly defeated and thrown back, the united hosts of France were to retreat to Verdun. But, however natural and promising in itself, the adventure miscarried fatally in execution. Moltke was too deep and too quick : the whole German organization too efficient; the French management too unskilful. And the end was tragic in the extreme.

Macmahon, accompanied by the Emperor, marching north from Châlons, with his I30,000 men, was caught in flank by the forces of the Prussian Crown Prince, which had steadily followed him up from Wörth over 


\section{86 NINETEENTH CENTURY EUROPE}

the Vosges, and now attacked and roughly handled him at Beaumont. A part of the army before Metz was also detached and sent in pursuit. And the Châlons deliverers soon became entangled in straiter toils than the besieged they came to deliver. Harassed, battered, and out-generalled, edged steadily nearer to the Belgian frontier, Macmahon was pushed at last into the Sedan hollow, on the French border, in the valley of the Meuse, half-way between Liége and Verdun. And here, on September I and 2, ever more completely surrounded by the foe (who mastered all the high ground, and swept the French with overwhelming artillery fire), unable to cut through the ring, or to escape, except on the side of Belgium-and even this avenue was cut off as the day wore onthe Châlons army came to an end. It had already lost heavily on the march ; over 20,000 of its strength had disappeared in the last days of August, another 20,000 (and more) on September I. What remained $-83,000$ officers and men, and with them $55^{8}$ guns, and vast stores of munitions-surrendered early in the morning of September 2. The Germans kept this cver after as a national fête-Sedan Day. It was the most complete military ruin in any single battle of the nineteenth century.

Sedan, of course, meant the fall of Louis Napoleon, his dynasty, and his empire.

When the news reached Paris, the chamber met late at night, and unanimously voted the deposition of the Emperor. Thiers and others worked for a monarchical restoration, in one form or another, but republican ideals, championed by Léon Gambetta, carried all 
before them, and the Third Republic was proclaimed. The Empress-Regent escaped to England.

But, although the Second French Empire had finished its course, the war had not. Many hoped that Sedan and the new régime in Paris would mean immediate peace. What was there now to fight about? Unfortunately, still much. As Ranke replied to the question-(which equally well represented the French attitude) 'A qui faites-vous la guerre?' 'A Louis Quatorze.' The new German nationalism was not satisfied with defeating the French rival: it was resolved to lop away from her what it considered the German portions of her land. Alsace, at least, where the German tongue had always survived, and dominated ; Alsace, which German patriots had demanded so loudly in I8I4 and I8I5, on the fall of the great Napoleon; Alsace, which national spirit had never ceased to claim all through the life of Bismarck; this Alsace must now be given back to the race which had held it till late in the seventeenth century. Here at least the robberies of Louis XIV. could now be undone. And undone it must be. What had been stolen, could, after many years, be restored. And restored it should be.

To such claims the new Republic returned as indignant a refusal as Gramont might have done. 'Not an inch of our territory, not a stone of our fortresses.' And with such negotiators Bismarck refused to negotiate. No German statesman, after Sedan, would or could have done otherwise. So the war had to go on.

Upon Sedan day itself Moltke made his arrangements for an immediate advance upon Paris, and for the 
investment of the French capital. Yet only forces of about 150,000 men were at first available: even at this terrible hour an army of 300,000 trained or halftrained defenders, with 2627 guns, was holding the powerful enceinte finished under Louis Philippe in 1840. But this garrison was not a field army.

By September I9 the invaders had blockaded Paris on all sides, but Gambetta, the soul of the Republican resistance, succeeded in passing over the besiegers' lines in a balloon (October 8), in reaching Tours, and in re-organizing the forces of French patriotism. And although Strassburg fell on September 27, several other leading fortresses about the same time, and Metz, with the whole army of Bazaine, ${ }^{1}$ and enormous stores, on October 27, the struggle was dauntlessly continued. Most of the regular armies of France had been defeated, captured, or dispersed, but the war was maintained by the raising of new levies a million strong.

Efforts to relieve Paris and drive out the foe were made from four centres-from the middle Loire, in the west; from the region of Bourges, south of Paris ; from the Amiens region, in the north; and from Franche Comté, in the middle-east. Twice was a combined attempt made to save the situation-once in the last days of November and the first week of December, 1870; and again in the latter half of January, I87x. But despite a momentary gleam of success in the region of Orleans, ${ }^{2}$ and despite the heroism of the French in every theatre of war, all ended in disaster.

While the last of the Republican armies, that of Bourbaki, after the failure of its brave and daring ${ }^{2}$ Still 188,000 strong. ${ }^{2}$ E.g. Battle of Coulmiers, Nov. $\mathrm{s}$. 
venture to relieve Belfort, was being forced back to the Swiss frontier (there to disappear into neutral territory, and be interned) Paris, now compelled to despair of relief, surrendered (January 28, I87I). She had endured a siege of more than four months, and a bombardment of four weeks, and she was now faced by the extreme of famine, and by utter ruin. Ten days earlier, when the end was already in sight, the new German empire, under the headship of the King of Prussia, as Emperor, was proclaimed in the Hall of Mirrors in the palace of Louis XIV. at Versailles (January I8, I87I). The work of Bismarck was, in its earlier form, completed.

The peace settlement, when at last it came, fulfilled the hopes on one side, and the fears on another, that had long been cherished. As the Germans had made public after their first August successes in I870, as had become more clear after the battle of Sedan and the fall of Metz, Teutonic nationalism was to be gratified to the utmost-barring some surpassing extravagances. All Alsace (except the French-speaking Belfort, and its little district, in the extreme south), and nearly one-third of Lorraine (including Metz) were annexed to the new German Empire as an Imperial Territory, or Reichsland, with Strassburg as its capital. And France paid a war-indemnity of five milliards of francs, or two hundred million pounds sterling. The ceded territory covered 5600 English square miles, roughly equal to Yorkshire, and had $\mathrm{x}, 600,000$ people - among the most quick-witted, industrious, and useful citizens of Central Europe, with a notable average of material wealth and prosperity. In the new 'Ger- 


\section{I90 NINETEENTH CENTURY EUROPE}

man ' Lorraine were iron deposits of the highest value, which the Imperial administration immensely developed.

To German feeling the transfer of Alsace, at any rate, was but the righting of a wrong, the undoing of seventeenth-century injustice. Only with the 'treacherous seizure ' of Strassburg in time of peace, and the forced 'Reunions' that followed, had France perfected her control of this land-politically German since the tenth century, racially German since the wandering of the nations and the fall of the Roman Empire in the west. In I87I Alsatians were still of German language, manners, and blood: all that was needed was to restore them to Germany. And (Germans hoped) might they not be proud of restoration to a Fatherland so powerful and victorious, so different from the 'complex and languid body' that had lost them?

Annexed Lorraine (in part, at least) was different: Bismarck himself was perhaps not so certain here. But for the insistence of his sovereign and of the military chiefs, he might have drawn the new border east of Metz. 'I do not like so many Frenchmen in our house.' For much of this Lothringen was French in speech, customs, and civilization. It had indeed belonged to the German kingdom, and Holy Empire, since that same tenth century, when Henry the Fowler consolidated the one, and Otto the Great 'restored ' the other. But Metz, and the best part of these Lotharingian lands, had been French since the days of our Edward VI.- - when the French monarchy, in alliance with the Protestants of Germany, had seized 
the Three Bishoprics, and defeated all the attempts of Charles V. to regain them (I552). Metz was so French, and had been so French, time out of mind, that Thiers, however extravagantly, could term it ' la ville française par excellence.' Its ' return' to Germany was widely felt to be a harsh and extreme spoliation.

The heart of Lorraine had been certainly French since those days of early Protestant strife; probably the same had been true much earlier: the heart of Alsace, which Arthur Young in I79I evidently considered still Germanic, was won by the French of the Great Revolution. When Napoleon was overthrown, German patriots passionately demanded the 'restoration' of Alsace. But Alsatians now clung to the new mother and disowned the old, and only with the strongest protests did they submit, sixty years later, to such a 'restoration.'

The Deputies from Alsace and 'German' Lorraine, the political representatives of the annexed territories in the Bordeaux Assembly which concluded peace with the invader, protested in vain against the transfer; but their solemn words remained in the memory of Frenchmen, and of many outside France. 'Delivered . . . by ... force to the domination of the foreigner, we declare a treaty null and void (nul et non avemu) which disposes of us without our consent.'

The settlement of $187 \mathrm{I}$ included something more than annexations or indemnities-the appearance of a fresh European state, and a fresh European leadership. The new German Empire, 'Prussia-Germany,' founded in 1866 with a more modest scope and title, was now extended to include all the Germanic world, 


\section{NINETEENTH CENTURY EUROPE}

(outside German Austria and German Switzerland) and definitely took the Imperial title. Nominally, in recollection and imitation of great historic memories, it was a revival : the Reich was 're-established.' But it was no longer 'Holy' or 'Roman' ; its nationalism was unqualified.

In the Galerie des Glaces at Versailles, where Louis had held his court and the old French Monarchy had appeared most dazzling, on the one-hundredand-seventieth birthday of Prussian royalty, ${ }^{1}$ King William was acclaimed as 'German Kaiser,' Emperor in a federation which comprised the bulk, and indeed all but a fraction, of the race (Jan. I8, I87I).

This youngest and most powerful of continental nations, the chief federal experiment of the Old World;with its Prussian sovereign as hereditary chief; with Bismarck himself as chief minister, Reichskanzler, or Imperial Chancellor; and with an Imperial Parliament or Reichstag, and a Bundesrath or Federal Council ; - was in its main lines a simple expansion, though in some respects a modification, of the North German union of I866, and marked the completion of the Bismarckian structure and system. By the wreck of French hopes, and the overthrow of French resistance, it was perfected ; and by the isolation and depression of France, in large measure, it was maintained. Certainly since the thirteenth century, and probably in all the past, there had been no 'Germany' like this-nothing comparable in union, in power, in consciousness, or in ambition.

The Franco-German War, moreover, brought with

1 On Jan. I8, r yor, Frederick of Brandenburg, son of the Great Elector, had taken the title of 'King in Prussia,' as Frederick I. 
it two 'outside' political results of obvious significance, however far from the theatre of conflict.

In Italy, Rome was seized by the new national state. On the 2oth September, I870 (the famous Venti Settembre), the troops of Victor Emmanuel entered the city of the Cæsars and of the Popes, by the Porta Pia. Thus the edifice of Italian unity, after eleven years of building, was formally completed ; and the temporal power of the Papacy, after eleven centuries of survival, was formally ended. The papa rè, practically dethroned in politics since 1860 , was now fully transformed into the 'prisoner of the Vatican.'

The French garrison had been withdrawn after the first disasters of August; and the events of Sedan, while they enforced upon the Francophil King a prudent abstinence from the trans-alpine struggle (' nous l'avons échappé belle '), ${ }^{1}$ removed every obstacle to the final step so long desired upon the 'national road.'

'There is the seat of empire,' had been the dream and the conviction of Mazzini, as of Dante. Italian patriots were yet to find that no political or social magic lay in geographical identity. Many centuries ago the spirit of Old Rome had died, or passed to others: no eternal or inherent virtue resided upon the Seven Hills.

After Italy, Russia. Within two days of the surrender of Metz the Russian government issued a manifesto repudiating the Crimean settlement as to naval rights on and beside the Euxine (October 29,

${ }^{1}$ So he was reported-a curious outburst of congratulation. N.C.r. 
1870). In supporting this, Bismarck paid a part of his immense debt to Russian friendship. "We had herein an opportunity of improving our relations with Russia.' 1 The defeat of France gave the opportunity. Few indeed, after Sedan, were prepared to go to war for the Black Sea clauses, "those most inept conclusions of the Peace of Paris.' 2

Even British statesmen such as Earl Russell ${ }^{3}$ dimly felt, like the German Chancellor, that 'one cannot permanently deny to a nation of a hundred millions the exercise of the natural rights of sovereignty on its own coasts.' But, as the British Government vehemently protested against the manner of the Russian action-' so Kalmuck,' as one described it-a conference of Great Powers was held in London, which formally ' granted ' the Russian desires, gave ' legality' to the Russian proceedings, and asserted the comfortable doctrine and position 'that ... no power could liberate itself from .... a treaty unless with the consent of the [other] contracting powers.' 5 (January I7. I87I.)

Throughout all the years of national reconstruction in the middle of the century, Britain took no effective part in continental politics. "We are not at the centre of the European movement,' laments Morier in the 'Sixties. British hopes and desires, disappointed in the Russian war, became more and more absorbed by home and colonial affairs. India for one thing witnessed radical changes. The mutiny which, a
1 B. ii. II4.
B. ii. II 4 .
Lord Granville's Life, ii. 72.
B. ii. 114.
-Lord Granville's Life, ii. 76. 
century after Plassey, threatened the very existence of the Anglo-Indian empire, was sternly suppressed; the shadow of Mogul imperialism which had so long lingered at Delhi was ended; and the government of India was transferred from 'John Company' to the British Crown. [I857-8.]

These were great events: On the other hand, the Burmese, Chinese, and Abyssinian Wars of this time (I852; I839-42; I856-60; I868), the wars against native tribes in South Africa (I85I-3, etc.), and the little Fenian war in Canada (I869), seemed feeble echoes of the great struggles of Europe. But the new policy of partnership, adopted by the mother country towards its real colonies of settlement, expressed by Lord Durham as governor of Canada in I838, and by the British North America Act constituting the Dominion of Canada in I867, is truly noteworthy. All these matters, and the whole subject of British colonial movement, with its steady transformation of so many regions of the earth, can be only glanced at here.

Few things in the British home development of the mid-nineteenth century were more notable than the Reform Bill of I867. Introduced by the Conservative government of Derby and Disraeli, with the avowed object of 'dishing the Whigs,' by anticipating a Liberal reform of similar character, the measure still further widened the electorate, establishing household suffrage in English boroughs, with a lodger franchise.

British sympathy with Italian nationalism in I859-6I, and with the Danish cause in I864, has been already 
noticed. We may perhaps add a word of surprise at the slender interest, and the inadequate perception shown by our people, and our leaders, in the momentous struggle of 1866 .

Down to I87I, British relations with other Great Powers had not undergone any fundamental change since the Crimean War, except perhaps in the case of France. It continued to be thought a real interest, or a natural desire, of the British people, as the Times ${ }^{1}$ expressed it, 'to see Germany strong and united'; and in spite of the Danish War this feeling did not die away. On the contrary, it was perhaps intensified as the prospects of Teutonic strength and union brightened in the 'Sixties.

Never had German influences and sympathies been more powerful among the Intellectuals. Thomas Carlyle, Matthew Arnold, Edward Freeman, William Stubbs, J. R. Seeley, and many other leaders of thought and knowledge were examples of this tendency. Although the Prussian military spirit, as then known, was not particularly acceptable to British citizens, it was widely regarded as the only possible re-creator and unifier of Germany, and so as working towards an end clearly good in itself.

Austria was somewhat disliked, especially for Italian (and, till $\mathrm{x} 866$, for Hungarian) reasons: but she was far from being regarded, like Russia, as a national foe, or an enemy of all righteousness.

The Tsardom, however, in spite of Liberal enthusiasms for Alexander's reforms, and particularly for the Serf-emancipation of I86I ("Russia has freed forty millions of human beings,' exclaimed Gladstone), had not won back the affection or trust of most English'See Appendix. 
men. Its advance through Central Asia caused deep anxiety and violent resentment. Another Russian war was very generally, though vaguely, expected as inevitable, and not wholly undesirable. And the Russian repudiation of the Black Sea clauses of the Treaty of Paris, in the latter days of the FrancoGerman War, scarcely intensifying British goodwill for the eastern neighbour, did not make this innate hostility less potent.

The relations of France and Britain had been remarkably serene for the ten years following the Presidential election of Louis Napoleon, in 1848 , but after the Orsini outrage, the Volunteer movement, and the Villafranca settlement, clouds came over the sky ( $1859-60)$. The commercial treaty negotiated by Cobden and Gladstone in I860 marks perhaps the close of the AngloFrench entente of the Palmerstonian age, as an effective thing.

As Lord Dufferin told the Emperor, soon after Villafranca, ${ }^{1}$ the French acquisition of Savoy and Nice roused a spirit of watchful jealousy in England; the ' sinister ambition ' of Napoleon was strangely credited with a universal and perilous force and craft ; and the 'Man of Sin' was by many supposed to be perpetually revolving schemes to the detriment of British interests.

The Polish crisis of 1863 and the Danish war of I864, as we have seen, scarcely did much to close the rift. Napoleon's scheme for a Congress to review the Polish question and the whole European situation, met with a chilling response from the British Govern-

2 Lord Dufferin's Life (Lyall), i, 122, 135-8. 
ment; British schemes for aid to Denmark received no warmer welcome from Paris.

The turnings and twistings of French statesmanship in 1866 and the years that followed, the hostility of the French people and government to Prussia and her 'mission' of German Unity, the passionate French anxiety to perpetuate (as far as might be) the old weakness and divisions of the Germanic world, the French inclinations towards 'compensation' in Belgium for Prussian advances in Germany, scarcely won admiration or sympathy in Britain. And the FrancoGerman war found a widespread disposition in the Island kingdom to regard France as the constant disturber of Europe, and French disasters as only too well deserved. In some quarters parallels were drawn between Canaanites and Frenchmen; to such minds the overthrow of the latter was wellnigh as much a divine judgment as the ruin of the former.

\section{ADDITIONAL NOTES ON THE HISTORY OF CULTURE.}

(i) $1865-66$

(a) In Religion, Catholic activities are shown in the appointment of Manning in 1865 as Archbishop of Westminster in succession to Wiseman ('a coup d'état of Providence,' as Pio Nono declared, delighted with his choice) ; also in Dr. Pusey's Eirenicon and in the alarm and indignation called out by the new 'Ritualism' in the Church of England.

More in the main stream of thought, at this time, appeared the achievements of Critical Theology, some of it tending in a rationalist direction, some not. Seeley's Ecce Homo, though violently decried by some representatives of the narrowest Orthodoxy (' a book vomited out of hell,' etc.), was anything 
but merely destructive (1865). Lightfoot's Commentary on Galatians still more belonged to the constructive side (1865). On the other hand, the German work of this time on the Old Testament was decidedly revolutionary, tending to assign the - priestly legislation ' to a period after the Babylonian captivity (e.g. Graf in 1866).

Carducci's Hymn to Satan in 1865 expressed in vehement form the anti-religionism of certain elements both in and out of Italy.

(b) In the 'Humanities' we have, in 1865, Matthew Arnold's Essays in Criticism, Ruskin's Sesame and Lilies, 'Lewis Carroll's' Alice in Wonderland, Artemus Ward His Book, Gaston Paris' Histoire poétique de Charlemagne, Lubbock's Prehistoric Times, Tyloz's Early History of Mankind, M'Lennan's Primitive Marriage. Carducci's Satanic Hymn has been noticed above : it revealed to Italy and Europe a new poet, and is the most brilliant of his works.

In 1866 appeared Ibsen's Brand, the first of his masterpieces of drama, and Dostoevsky's Crime and Punishment, one of the most famous of Russian novels. Bryce's Holy Roman Empire and Yule's Cathay, both works of eminent service to History (the latter also to Geography), also made their entry in this year. Systematic excavations now began at Jerusalem.

(c) In Natural Science there was, in 1865, very important work by Lister in antiseptic surgery, by Pasteur in the study of disease, by Ludwig in the study of blood-pressure.

In 1866 Haeckel published his General Morphology of Organisms, Owen his Anatomy of Vertebrates. Kovalevsky in Embryology and Schiaparelli in Astronomy break new ground. The explorations of Rohlfs in North Africa (in Morocco, on the Niger, on the Gulf of Guinea, and in the Libyan Desert) are valuable, not only for geography, but for the future of trade and colonial advance (1866, etc.).

(d) In Social movements it may be noticed that the ' Gothenburg system' (of State Control of the sale of spirits) was introduced into Sweden in 1866 ; that the Italian People's Banks now began in Milan, whence they quickly spread over the country ; that the Cobden Club was founded in England; and that Irving, Bancroft, Hare, and Wyndham, all commenced their London stage-life in the same year (I866), 
(ii) $1870-7 \mathrm{I}$.

(a) In Religion, the Revision of the English Bible is begun, with the New Testament, in 1870 , but the most striking events of the year's Church History are connected with 'Catholic Revival.' The Vatican Council decrees 'Papal Infallibility' for the Roman Communion (i.e. the Pope, when pronouncing officially, or ex Cathedra, on Faith and Morals, is to be accepted as under divine guidance). Much opposition is offered to the decrees, and many Bishops abstain from voting. Meantime John Henry Newman publishes his Grammar of Assent, one of the most skilful of his efforts in Catholic philosophy; while Ritschl's Atonement represents, from a master-mind, a new constructive and devotional tendency in the critical theology of Protestant Germany (1870).

In the following year the struggle between Church and State in Germany, and especially in Prussia, soon known as the Kulturkampf or War of Culture (i.e. against Ecclesiasticism), begins to develop. To some extent it is connected with the struggle between maintainers and opponents of the Vatican decrees within the Roman Church, from which springs the Old Catholic or Alt-Katholisch School and Community. The great historian and theologian Döllinger is excommunicated and becomes the real leader of the Old Catholics. In Prussia legislation is adopted to limit the powers of the Roman clergy : in opposition, Windhorst founds the Centre, Roman Catholic, or 'Clerical' party.

(b) In the Humanities, D. G. Rossetti's Poems, Disraeli's Lothair, Lowell's Study Windows, Wagner's Essay on Beethoven, Jonas Lie's first Norwegian Sea Stories, and Mommsen's Staatsrecht (a study of Roman Government which completes his Roman History of 1855 , etc.) belong to the year 1870 . In the last months of the Second Empire in France, that monument of its luxury and taste, the Paris Opera House, was adorned with Baudry's paintings.

In 187 I Zola begins his Rougon-Macquart series of novels : Rosegger issues his Stories from Styria, Ruskin publishes Fors Clavigera; Maine in his Early Institutions studies especially Old Irish society ; Jevons' Theory of Political Economy applies mathematical method to economic analysis; Delbruck's Researches in Syntax is a landmark in Philology; the first 


\section{THE UNITY OF GERMANY}

Impressionist Exhibition in France is no less a landmark in Art.

(c) In Natural Science, the invention of smokeless gunpowder; Crookes' Spiritualism and Science; and Galton's work on Heredity, are to be noticed in 1870. Darwin, now completing his Descent of Man, publishes this in $187 \mathrm{r}$.

Nordenskjöld's exploration of the interior of Greenland is the chief event in Geography in 1870 . In the following year, Livingstone discovers part of the upper course of the Congo.

(d) In Social Progress, the creation of Board Schools, for elementary education, in England; the prohibition of infanticide in British India; and the foundation of Keble College, Oxford, by the High Church party, are leading incidents in 1870 .

The year $187 \mathrm{I}$ is marked by the opening of the Mont Cenis tunnel, the first piercing of the Alps ; by the legalization of Trades Unions in England; by the foundation of Catholic and Protestant Socialist parties in Germany ; by the foundation, in its earliest form, of Newnham College, Cambridge ; and by the abolition of religious tests in English Universities. 


\section{CHAPTER VIII}

RECONSTRUCTION AND THE EASTERN QUESTION

The Franco-German War and the Peace of Frankfurt wellnigh close the great period of national reconstruction which is the foundation and source of present conditions. They also begin that age of armed peace to which the last generation belongs. Again, the events of 1870 and $187 \mathrm{r}$ bring us out of a period in which France plays a leading part, sometimes the leading part, in European politics, and introduce us to an age in which the new German Empire occupies the centre of the European stage.

Bismarck had been, above all men, the creator of the new conditions; he now becomes their preserver : although, in order to preserve, he constantly develops. His policy undergoes a profound change. It had been one of daring, of adventure, in a sense, and of revolution; it now becomes one of caution and conservation, although the old spirit is always ready to seize fresh opportunities. The aims of the Iron Chancellor had involved fundamental alteration of the European position: they are now consistent with a resolute opposition to res novae. For Germany, as her pilot said, had now become 'one of the satisfied'-des satisfaits. 
Lord Salisbury, like Signor Crispi, thought he recognized in the later Bismarck a pillar of European peace, a principal obstacle to conflagration, a 'fireproof block' (as Morier wrote of certain other influences). Nor was his judgment wrong, if only it were granted that Germany was a 'great and beneficent work of fortune' (as Polybius said of Rome), and that the German hegemony on the Continent bore hardly on no one but fire-brands and enemies of progress and of peace.

No one recognized more clearly than Bismarck that all things obeyed a law of movement. He and Germany were 'satisfied,' but there could be no standing still in that satisfaction. In his most perilous and friendless time he had provided his country with one strong, though informal, alliance. But down to the close of the French War this Russian friendship had been the only solid asset of his statesmanship, in this direction. And the extraordinary successes of Prussia, however pleasing to the Tsar, had awakened jealousy among the statesmen, the soldiers, and the aristocracy of the eastern neighbour.

The Italian alliance of 1866 , concluded for a special object, and not based on any deep or wide community of interests, had not yet developed into a permanent league or friendship. High diplomatic skill, brilliant and rapid military success, had alone prevented the possibility, in 1870 , of Italian aid to France.

Relations with Britain had been strained and dangerous at the time of the Danish War, and no marked cordiality had yet reappeared in politics, although spiritual sympathies were never more powerful $[c .1870-I]$. 


\section{NINETEENTH CENTURY EUROPE}

While, lastly, the restoration of the "old friendship with Austria,' though made possible by the moderation of the settlement in 1866 , had not yet been attained. Even at the close of the French War, Beust was still in control of the policy of the Dual Monarchy. Although his hopes of intervention had been baffled ('je ne vois plus de l'Europe '), he would never be a minister of the reconciliation between Vienna and Berlin.

The Bismarckian revolution in the balance of power was not, and perhaps could not be, effected without the creation of bitter resentments and fierce plans of revenge. Two Great Powers had been defeated and humbled, one at least considered itself despoiled and outraged, to clear the way for the new Empire. A small state had been stripped of half its territory, in the pursuit of the same end. And even if Denmark must forget and Austria might forgive, France would do neither, and in Russia itself a spirit of envy was nourished by recent events, dangerously sympathetic to the French vendetta.

Now, therefore, the German statesman, who had become centre and mainspring of Continental politics, directs his main efforts to conciliation and alliance. He appears henceforth in the unaccustomed part of a devotee of peace, a 'Friedens-fanatiker.' If he now calls attention 'to the steepness of the staircase and to his physical superiority,' he aims at the formation of leagues rather than at the crushing of obstacles. And on the whole he succeeds in persuading "Europe" that its interests lay in the maintenance and development of the new conditions, and in the defeat of any 
serious attempt to alter the position secured by the Peace of Frankfurt.

Bismarck began his new system by the formation of a triple entente-the Drei-Kaiser-Bund or Three Emperors' League of 1872 . This understanding with Vienna and Petersburg had already been planned by the Prussian statesman in September, I870, in the days after Sedan: it had been foreseen and made possible in the settlement of 1866 . 'Never make your enemy, if he can ever be your friend, so angry that he cannot get over it.' This policy, the policy of Nikolsburg and Prague, now after six years bore fruit. Austria is found linked with the Prussia which had thrust her out of Germany, and with that outraged Russia who seemingly offered once again the hand of friendship, through the mediation of Berlin. And as that league was formed 'with the further idea of bringing in Italy,' it was prophetic of the future in other ways as well. It is curious to observe the Italian monarchy hovering on the edge of this new and strange constellation, from September, 1873, the time of a famous visit of Victor Emmanuel's to the German imperial court.

The Drei-Kaiser-Bund, of course, involved the retirement of the anti-Prussian Beust from the Austrian Chancery ; the abandonment of any plans for Austrian restoration in the Germanic world; the ratification by Vienna of Bismarck's work. It was professedly directed against the 'Red International,' the revolutionperil, in all three states. It was supposed to guarantee sobriety and peacefulness in Russian, as in German, policy. It was considered a new, stronger, and saner 
Holy Alliance. Valuable and even vital, it was hoped, might be the results.

Yet these expectations faded like a mirage. The League had no sufficient substance, and vanished as the first crisis approached. The close of the Bismarckian age was to see a real Triple Alliance, formed by a readjustment of the earlier entente-the German Empire still in the centre, with Austria-Hungary and Italy definitely bound to her in military agreement ; while Russia, on the edge of this system and to some extent confronting and confronted by it, is secured by secret understanding to its predominant partner. But much barren land had to be crossed before this oasis was finally reached; Bismarck, like other explorers, here at least was forced to attain success through failure.

A decisive test came in 1875 . 'The first overclouding of my hope,' writes the author of the Kaiser-Bund himself, 'was caused by Gorchakov, who spread the falsehood that we intended to fall upon France, before she had recovered from her wounds.' Falsehood or not, a gulf now threatened to open beneath German feet. The eastern friend, who had so often and so essentially safeguarded and assisted, now seemed ready to turn against the Prussia it had fostered, and against the Germany it had helped to create. The Prussian military party, in fact, was dragging the whole of the new empire into danger. Reckless of consequence, it was pressing for a fresh war with the old enemy on the west, so wonderfully and dangerously recuperating. And such a prospect threatened to raise a wide and powerful coalition against the aggressor. 
The complete history of this war-scare is still far from clear; the most diverse views have been and are still held; but among various explanations and indictments it may be permissible to agree with that of the former oracle of the London Times'Herr Oppert from Blowitz in Bohemia.' This interpretation was widely accepted in England before recent controversies and enmities had arisen, and according to this the German Chancellor aimed at thwarting his own hotheads by disclosing their plans prematurely

But the attitude of Russia and of Britain; the remonstrances of Alexander and of Victoria with his sovereign; the apparent readiness of the Tsar's government to respond with sympathy to French appeals; the anti-German zeal, and selfgratulation, as he viewed it, of his old godfather in diplomacy, Prince Gorchakov ('maintenant la paix est assurée') irritated Bismarck not a little. From this time, it is probable, he definitely made his choice of Austrian alliance, relegating the Russian friendship to a secondary place.

The Third French Republic, after the hideous disaster of the German War, had passed through a civil war hardly less tragic. Certain extreme Republicans rose passionately against the Bordeaux Parliament which concluded peace-an assembly of safe and moderate men, in majority monarchists of one shade or another, deeply suspected by large sections of the working classes, and necessarily discredited by the humiliating treaty they had been forced to sign. Outraged nationalism played a 


\section{NINETEENTH CENTURY EUROPE}

greater part in the 'Commune' than is always recognised.

Nominally demanding the division of France into a number of self-governing districts or communes, each more or less independent of the rest ; nominally fighting against the centralized character of modern French administration-the 'Communards' were really aiming at the establishment of a 'Red' Socialist state. Triumphant for the moment within the walls of Paris (March, I87I), they failed to carry the country, and were crushed after a desperate struggle, marked by almost every kind of barbarity on both sides (May, I87I).

In the fury and terror of their ruin, the Communists, like a Samson, nearly dragged down the temple upon the heads of all : Paris for a day or two was in danger of destruction, its bourgeois and gentry in peril of wholesale massacre. The murdered Archbishop, the smoking Tuileries, might have been only a beginning. But the prisoners released by the Germans after the armistice gave victory to the forces of order, and the Communists were killed like mad dogs, or transported to life-long penal servitude. Seven thousand suffered the latter fate.

Yet, after this frenzy, the nation began to find itself once more. Thiers guided it between reaction and anarchy to a moderate Republic. In November, I872, he ventured to make a pronouncement in this sense. Meantime he bent all his energies to the payment of the indemnity to the German treasury, and to the liberation of the occupied territory from German garrisons. Before his resignation, on May 24, 1873, the liberator had accomplished these ends. Further, he had 
re-formed the army on the basis of universal service.

His work well stood the test of time. Marshal Macmahon, succeeding him with every wish and hope of a royalist restoration, found himself as incapable as Thiers of composing royalist factions, as imperiously driven as Thiers towards a recognition of the de facto conservative Republic. On Feb. 25th, 1875, with the formal constitution of the new French state, the prescience of Thiers was vindicated. The military law of March, I875, providing France with a war strength of $2,400,000$ men, equally confirmed Thiers' offensive-defensive policy.

The strength and depth of 'revenge' feeling, the burning passion for the recovery of the lost provinces, justified the attitude he had taken upon the annexations-as a danger to peace. The recovery of the French people, of French credit and material prosperity, from the débâcle of the war, fulfilled the hopes of his sane and courageous patriotism. But all these things awoke such anxiety in Germany, or at least in the German army-command, as to produce the crisis (Bismarck's ' crisis-myth' ${ }^{1}$ ) of 1875 .

Ecclesiastical politics were also matters of urgency in these intermediate years, between the Peace of Frankfurt and the Russo-Turkish War; and like other Continental matters at this time they tended to find a central field of action in Germany.

The Vatican Council of 1870 was (and was understood to be) not merely of religious, but of universal interest. It stood for the definite and renewed triumph of

B. ii. I80. 


\section{IO NINETEENTH CENTURY EUROPE}

Ultramontane principles, or the Highest Churchmanship, within the Roman obedience. Its results (in the Papal Infallibility decrees) were especially distasteful to a section of moderate German Catholicism. And the Papacy, after the Council, and in the spirit of the Council, was not only resolute in its opposition to the new Kingdom of Italy, scornful of all offers of accommodation, ${ }^{1}$ and uncompromising in its protest against the occupation of Rome and the abolition of the Temporal Power, but also ready for unyielding warfare with secular claims in the new German Empire, or elsewhere.

Here, in Germany, the State had quickly taken action to protect certain Old Catholics-and especially professors in the Universities, who, for their opposition to the Vatican Decrees were threatened with temporal penalties, such as deprivation. And in opposition to such State action a Centre or Catholic Party now developed in the Reichstag; and in the Empire, to support the Pope, the Council, and the official attitude of the Roman Church. The strife grew rapidly. Bismarck raised the banners of Protestant and secular independence, warned against spiritual tyranny, and proclaimed ' No Canossa.' A mediaeval German Emperor in 1077 was a weaker man than the German Chancellor in 1872 or 1877. This time there would be no submission to a Hildebrand. Nor was there any such abasement. But there was, after years of bitter strife, compromise, peace, and even the beginnings of a fresh alliance.

The May Laws of 1873 expressed in Prussia, in the fiercest form, this spirit of 'Liberal' and 'civilized' resistance to priestly despotism. And from this spirit

${ }^{2}$ E.s. by the Law of Guarantees. 
arose the self-styled Kulturkampf or War of Culture against Obscurantism, by which the conflict was marked in Germany, to which a great man of science gave a title, ${ }^{1}$ and which raged without abatement to the death of Pio Nono. By these Mai-Gesetze Church appointments were made conditional upon state sanction; state inspection of seminaries was established; candidates for ordination were directed to take a course of study at a national university, together with a state-examination; public excommunication was forbidden; and appeals were legalized to the state authority, against ecclesiastical sentence. The Jesuits were to be expelled, and civil marriage was to be made indispensable, in addition to the Church ceremony.

In pursuing this anti-clerical policy Bismarck found so little satisfaction; so many fresh sources of difficulty and annoyance; so much passive, impalpable, conscientious opposition; that he readily welcomed the opportunity afforded by the death of an irreconcilable pontiff and the accession of the most diplomatic of recent popes (I878). Where Pius IX. would not or could not find a loophole of agreement, Leo XIII. was skilful in discovering possibilities of practical compromise, while abandoning no theoretical claim. Diplomatic relations were restored; and by a final arrangement in 1887 something like an entente was established between Bismarck and the Vatican. The Curia, to the astonishment of most men within and without the Roman fold, now forbade the Centre party to vote against the new army bill of the Imperial Government. Years before this the more oppressive 1 Virchow named it Kulturkampf. 


\section{iI2 NINETEENTH CENTURY EUROPE}

provisions of the May Laws had been tacitly abandoned [I880].

It is possible that, in the Kulturkampf, Bismarck had some idea of adding a national German church to all his other work for German unity. He shared a common belief, however mistaken, in the future of the Old Catholic movement. In place of the withered stump which later history shewed, he and others saw a mighty tree. Into this tree, he may have hoped and believed, would be absorbed all the life of German Catholicism. And with the Old Catholics a re-union of German Evangelicals might well be brought to pass. Döllinger, the mighty man of the Alt-katholisch ranks, was lecturing on such re-union in 1872 ; Pope Pius, men said, was plainly running the Catholic Roman Church upon the rocks in his mad hatred of the modern spirit; was there not a dawning prospect of a Church of Germany?

In any case, the issue of the Kulturkampf helped towards the weakening of the German Liberals, the decline of the National Liberal party, and the dissolution of that alliance of theirs with the Chancellor which had been so much cemented by the antihierarchical feeling. Alike against their religious policy and their economic Bismarck was now ${ }^{1}$ revolting. He was turning, or returning, to an attitude far more congenial to his chief partner and best friend, the aged Emperor; he was, with extraordinary adaptability, preparing to substitute Papal friendship and co-operation for a coercion (as ' Old William' bemoaned) 
of a third of the German people; and he was making ready to adopt a carefully calculated Protection in place of a moderate Free Trade. Lastly, while still endeavouring to overawe and crush revolutionary tendencies, he was entering, here also, upon a remarkable experiment in conciliation. By old Age Insurance and other measures of State Socialism the working classes were to be won away from the Red Spectre.

The year 1875 was crowded with political movement. For it not only witnessed the excursions and alarms of a new Franco-German danger, the definite emergence of a Third French Republic, the height of the Kulturkampf, the temporary retirement of Gladstone from British Liberal leadership, and Disraeli's purchase of Suez Canal shares (the beginning of recent British influence in Egypt) - but also the opening of a new chapter in the Eastern Question.

The revolution in the Balkans, the next important rapid in the main stream of European history, now commenced with risings in Bosnia, with stirrings in Bulgaria, and with threatenings in Montenegro and in Serbia-always against the Turkish oppressor. In all these provinces a state of open war developed; through the Serbian war and its disastrous conclusion, still more through the Bulgarian massacres, Russia was drawn into the struggle (April, I877).

Meantime Bismarck, in pursuance of his new policy, had moved, though very cautiously, towards Austrian alliance, and away from anything like an exclusive Russian entente. Gorchakov should find, to his cost, what a harvest he would reap from his recent action. 


\section{I4 NINETEENTH CENTURY EUROPE}

In the autumn of 1876 the enquiries of the Tsar's government as to the German attitude, in the event of an Austro-Russian war, were answered by a warning that Berlin could not tolerate the destruction or crippling of the Dual Monarchy.' 'We could endure that our friends should lose or win battles against each other, but not that one of the two should be so injured that its position as a Great Power... should be endangered.' The result of this was that ' the Russian storm passed from Galicia to the Balkans,' and that Alexander and Franz Josef concluded the Convention of Reichstadt on January I5, 1877. The essence of this agreement was that, so far and so long as Russia, in the event of victory over Turkey, was to exercise influence in Bulgaria, so far and so long should Austria exercise influence in Bosnia. This treaty, and not the Berlin Settlement, was the origin of the Austrian occupation of the Balkan north-west, and this it was which secured the neutrality of Austria in the Russo-Turkish conflict -the last of the great European and nationalist struggles of the nineteenth century, and not the least important.

The war opened with a rapid and far-reaching Russian advance in Europe, and a slight advance in Asia. Rumania, without immediately joining the invaders, opened to them her frontiers, and assured their march from Pruth to Danube in peace and comfort (May-June, I877). The great river, the true Turkish frontier since I866, was then forced (June 27July I5) ; a flying Russian corps dashed on to the main Balkan range, and seized the Shipka Pass-one of the 
chief points, as it proved, in the strategic geography of the war (July I7-I9, I877). Meantime in Armenia, likewise, the Turks were thrown back. The keyfortress of Kars was invested. The world expected, hoped, or feared (as in 1828-9) a speedy end to the campaign.

Then came a famous Turkish rally. First, Mukhtar Pasha relieved Kars, and pushed the Russians pretty well out of Turkish Asia, for the moment (June-July). Next, Osman Pasha, entrenched at the unimportant town (and important road-junction) of Plevna, in north-western Bulgaria, a little south-west of Nikopolis on the Danube, where a great part of the Russian armies had crossed, repulsed the latter in two bloody battles (July 20 and 30), and for a time seemed to alter the whole complexion of the war. The Russians had failed to carry the day by a coup-de-main, and the Turks had shown all their old prowess in defence. And in spite of vigorous Russian reinforcement, carried on through all the anxious days of August; in spite of the definite accession of the Rumanians to the Christian side; and in spite of the capture of important points, and the interruption of Osman's communications with the main body of his people, Plevna yet a third time repulsed its assailants with tremendous loss towards the close of the summer (September II-I2).

But without foreign aid to the Muslims, or domestic panic among the Slavs, there was only one possible result. Russia had but to utilize, with some honesty and sense, her resources in men and material, to turn the scales once more. Even in generals she was superior. Skobelev, though not in supreme command, put new life into the Russian soldiery. Since Suvorov 


\section{I 6 NINETEENTH CENTURY EUROPE}

the Slavs had not seen such a leader. Todleben, the defender of Sevastopol, summoned at last where he should have been at first, quite outranged Osman. Plevna was now effectively besieged. By the last week in October the investment was completed (October 24), and seven weeks later famine compelled the Turks to move. 'Masking the movement with great skill,' Osman struck westward early in December. But after some initial success, his movement came to a standstill. 'A ring of fire like that of Sedan encircled the Turkish army,' and the whole force of 44,000 men surrendered (December ro).

While Plevna was besieged, the rest of the Turkish operations were remarkably inept. Thus a series of fruitless frontal attacks on the Shipka Pass (August 23, September I7, etc.) only added encouragement and glory to the Russian arms. In eastern Bulgaria, towards the Black Sea and the mouth of the Danube, the Muhammadan commanders made a considerable show of activity and force, without effecting anything. And, in Armenia, Mukhtar's early successes were followed by crushing reverses ; Kars fell (November 8) ; and the triumphant 'Moscovites' advanced upon Erzerum.

With Plevna, the whole Turkish cause collapsed. Serbia now joined Russia (December I4); and the Slavonic armies poured over the Balkan passes. The Turkish battalions fronting the Shipka, on the south of the range, were encircled and captured: 36,000 men surrendered (January 9, I878). General Gurko, the leader of the first dash which won the Shipka, led the final dash which won the war. Pushing on with astonishing speed, he shattered the remnants of the 
Turkish army of the centre at Philippopolis (January I6 and I7, I878), and entered Adrianople three days later (January 20).

After an appeal to Queen Victoria, which led to ineffective $^{1}$ attempts on her part to mediate with Alexander, 'in the hope that you may accelerate negotiations for an armistice,' the Sultan was obliged to ask peace directly from the Tsar. By the Agreement of Adrianople (January 3I), preliminary terms were laid down, sufficiently alarming to all rivals and enemies of Russia. A great Bulgaria, practically independent, reaching to the Egaean, was to be erected. Rumania, Serbia, and Montenegro were to be freed from all trace of Turkish overlordship, and territorial and financial indemnities were to be paid to Russia.

Thus, after a desperate struggle, which Russia had too readily assumed would be a promenade militaire, giving occupation to the trop plein of the army (and so certain foreign military experts had assured the Russian people), Turkey was defeated and dismembered,-in Europe, over the half of her possessions ;in Asia, over a small portion of the field.

If Austria-Hungary had watched these closing scenes of the struggle with watchful jealousy, the British conservatives witnessed them with manifest anger. Only the sudden and complete break-down of Turkey seems to have foiled the plans of Lord Beaconsfield and his party for armed intervention.

1 For next day the British Mediterranean fleet was ordered to steam up the Dardanelles to Constantinople (Jan. 23), a destination modified to Besika Bay on Jan. 24. 


\section{I 8 NINETEENTH CENTURY EUROPE}

The Bulgarian atrocities, which spurred Russia to action, disabled the right arm of British friendship. Pro-Turkish intervention might be the ideal of the Beaconsfield government-or rather of its leader, for the Cabinet was acutely divided-but the client's case was too bad. By the Turks' own action a winning defensive was given to the Liberal Opposition-to lead which Gladstone emerged from his retirement, and made good the boast of Achilles-' they shall know the difference, now that I am back again.'

Few conflicts of the last, or any, century seem more righteous and less ignoble than this War of Liberation. If Dean Colet had lived to see it, he might, perhaps, have modified his view, 'An unjust peace is better than the justest war:' The Turkish rule over the Christian peoples of the Balkans is an awkward case for the application of this maxim.

Disraeli, in his characteristic vein of irony, parodied the conflicting feelings of his Ministry, as the crisis of the war approached, as the Russian army and the British fleet neared Constantinople, and as the local struggle seemed, hour by hour, to move towards an Armageddon. There were six parties, said Lord Beaconsfield, in the British Cabinet. The first wished for war with Russia here and now. The second for war if Constantinople were really imperilled. The third, for peace at any price. The fourth for peace, until the Moscovites had seized Stambul; then for war to turn them out. A fifth party longed to see the cross on Saint Sophia. 'And then there are the Prime Minister ${ }^{1}$ and the Chancellor of the Exchequer, who

${ }^{1}$ Pretty certainly the leader of the first or thorough-going war party. He delightfully couples himself with the most charitable of statesmen, Sir Stafford Northcote. 
desire to see something done, but don't know exactly what.'

The six weeks guarantee for which Disraeli hoped (between the Russians' irruption into southern Bulgaria and their arrival before Adrianople) was not forthcoming:- - the interval was but eleven days. But when the invader, after the Adrianople Convention, and as a result of the same, approached still closer to the imperial city, and (on February 6, 1878) occupied the Chatalja lines, the chief natural and artificial defence of the Constantinople region, running from Euxine to Marmora, the British fleet passed through the Dardanelles and approached the Bosphorus. It would probably have anchored before the capital but for the Russian threat of entering Stambul in such an event. Meantime the Hapsburg Monarchy, more than doubtful (like Queen Victoria) of Russian good faith, and fearing that the Reichstadt agreement might now avail but little, massed its troops on the Carpathians, on the Transylvanian Alps, and in Galicia, and joined with Britain in demanding a European Congress to settle the terms of peace.

During February the idea of such a Congress to meet at Berlin, where Bismarck offered to act as 'honest broker' between interested parties-for to him, as he professed, the whole Eastern Question was not worth 'the bones of a Pomeranian grenadier'-was accepted by all the Powers.

As a last diplomatic move, partly perhaps to present the Congress with a fait accompli, Russia now compelled the Turks to sign, at the little village of San Stefano, near Constantinople, the famous Treaty of that 


\section{NINETEENTH CENTURY EUROPE}

name. Here again figured a Great Bulgaria, reaching to the Egaean and the frontiers of Albania. In this state a Russian High Commissioner was to control the government for two years, and Russian troops were to occupy the country for the same period. Here also, at San Stefano, appeared the complete emancipation and effective aggrandisement of Rumania, Serbia, and Montenegro. Here, again, were territorial compensations to Russia, but now at last well-defined, and including the Bessarabian strip lost by the Crimean disasters, and an important block of Turkish Armenia, including Kars and the valuable port of Batum. Bosnia and the Herzegovina were to have 'free institutions' under joint Russian and Austrian protection and control-a condition hardly in accord with the terms of Reichstadt.

As a result of San Stefano, acute tension was renewed in Anglo-Russian and Austro-Russian relations. Another great war, involving many combatants, seemed again to lie in the logic of history. The Beaconsfield Cabinet called out the reserves, ordered the transference of a strong body of Indian troops to Malta, and circularised other states on the grounds of British opposition. The Austrian and Hungarian parliaments voted large credits, with the almost avowed purpose of Bosnian occupation.

But Liberalism in Britain, Nihilism and Radicalism in Russia, and Slavism in the Hapsburg state, helped to check the ardour of the governments most concerned. Austria was not really desirous of a mortal struggle with the Tsardom if her Bosnian sphere of influence, her irreducible minimum, could be obtained 
without bloodshed. The Russian emperor, liberator and reformer rather than fire-eater, weighed carefully the exhaustion of his armies, the defects revealed by the war, the domestic dangers, the omens of a new anti-Russian coalition, the prospect of nothing more effective in the way of alliance than the friendly neutrality of the German Empire, which itself would not permit the destruction of Hapsburg power.

Even in Britain, loud as was the voice of warlike feeling (this was the day of the first Jingoes) a great part of the electorate was all for Gladstone and peace, for retrenchment and reform. Disraeli might claim to speak with the voice of England: no united country was behind him.

And beneath all Bismarck worked for peace and his Congress at Berlin. Franz Josef and Andrassy, for the Dual Monarchy, were certain of his support in all that the Monarchy really considered essential. Alexander, for Russia, also hoped for similar backing from the friend of both sides, who had been so long a champion of Russo-German friendship, and who spoke of himself as an extra Russian Delegate at the council board of Europe. ${ }^{1}$

A decisive trend towards settlement began when Count Shuvalov, for Russia, and Lord Salisbury, for Britain, came secretly to agreement (May 30, I878); in all its main lines this compromise was followed at Berlin, and solved the most serious difficulties of the

${ }^{1}$ At the end of his life Bismarck writes in his Reflections (ii. 285. E.T.), 'I believe it advantageous for Germany if the Russians were to establish themselves at Constantinople and had to defend that position.' 
peace-makers ${ }^{1}$. As a complement to this, Britain concluded another secret agreement, at this moment, with the Porte, by which she assumed responsibility for the future defence of Asiatic Turkey against Russia, while the Sultan 'assigned' to his insistent protector the island of Cyprus, ' to be occupied and administered ' by her. So all the Great Powers met in Congress at Berlin, with a fair prospect of agreement, on June I3, I878, and a month later, on July I3, the final treaty was concluded.

To some extent the Berlin settlement was a realisation of the earlier Russian policy, and advance, checked by the Crimean War. To some extent, again, it was a disappointment of Russian hopes.

The Christian peoples of Rumania, Serbia, and Montenegro-within the limits of these Kingdoms, or Principalities, as now defined-gained complete independence, and the position of sovereign international states.

Part of Bulgaria (north of the main Balkan range) was made a vassal state of Turkey, with practical independence, though under Turkish suzerainty and tribute. Another part was given a measure of autonomy-or internal self-government-under modified Turkish rule and military power. Turkish garrisons were here maintained, but only of a certain strength. This was the Eastern Rumelia of which Disraeli made so much. Russia was then regarded, and regarded

1 'I have no great faith,' wrote Disraeli, 'in a real understanding with Russia as to our Eastern possessions, but much faith in a supposed understanding, which will permit us to avail ourselves of the present opportunity of settling and strengthening our frontiers (Disraeli's Life v, x. I6). 
herself, as the special protector, as she had been the liberator, of Bulgaria.

Greece, after much negotiation, was aggrandised by Turkey's cession of Thessaly and part of Epirus.

Certain portions of the Bulgarian, Serbian, and Greek races-certain lands, such as Macedonia, inhabited by all three, sometines one or another dominating, sometimes all hopelessly intermixed-were left under Turkish rule. The questions arising therefrom were the principal causes of the Balkan War of I9I2-I3, and of the quarrel of the Balkan allies in 1913. And these last, in turn, left us the Balkan situation of the Great War, and of the present time.

Certain parts of Turkish Armenia (mainly as defined at San Stefano) were ceded to Russia. Rumania also, as we have seen, had to surrender to her big brother the portions of Bessarabia torn away from Russia by the Crimean War. Austria-Hungary was put in occupation of Bosnia and the Herzegovina, and Britain occupied Cyprus, and assumed the responsibility of defending the Asiatic provinces of Turkey against future Russian attack. All to 'consolidate the Turkish Empire'-whose integrity the Powers were so firmly determined to maintain, while presiding over its amputation.

Thus the Christians of the Balkans were in great measure freed and nationalised, and for a time, at least, and in certain parts, Russian influence was obviously increased. But none the less Russia considered herself, in general, to have been disappointed. And this disappointment was even accentuated in the next years, largely through the ill-judged Balkan diplomacy of Alexander III. (I88I-I893). 
Even the results of Reichstadt were not realised While Austria entered into complete possession of the Bosnian north-west, Russia found herself unable to exercise any really controlling influence in Bulgaria. Under Stambulov ${ }^{1}$ the latter even defied Russia, and executed and exiled pro-Russians.

Rumania, again, under her Hohenzollern ruler, declaring herself unforgivably wronged by the Bessarabian business, took up a frankly anti-Russian attitude, and more or less attached herself to the Austro-German league of 1879 , and to the Triple Alliance which, in I88I-3, grew out of this.

Greece, which from the beginning of Greek independence (1820-29) had owed so much to Russia, never showed the Slav Empire any greater excess of gratitude, after her new gains, than before. And lastly Serbia, in spite of all that Russia had done for her, settled into a position of at least equal dependence on, and equal compliance towards, Austria. It was in view of all these developments that Alexander III. complained so bitterly of Balkan ingratitude, and toasted his 'only friend and ally,' Montenegro.

Dominant in Bulgarian politics, 1884-1894. 


\section{CHAPTER IX}

LATER BISMARCKIAN TIMES-I879-I890

In all these Balkan troubles, we have seen, through the whole of the Russian 'Crusade' against the Muhammadan oppressor, as in the Congress and settlement of 1878 , the German attitude, Bismarck's official policy, had been one of detachment, of disinterested neutrality. In the Eastern Question Germany had nothing to gain-no case, and no wish, for interference.

But there was certainly more than this in the mind of the Chancellor-for he, and not the Emperor William II., is the true founder of German influence in the Turkish world, as he is the ultimate cause of a German sovereign and dynasty both in Rumania and in Bulgaria.

He first takes the Sultan under something like German guardianship. He, first of German statesmen, deprecates any further 'bullying of Turkey.' $\mathrm{He}$ lays the foundation of the Baghdad railway (from I888). $\mathrm{He}$ begins the continuous and permanent training of Turkish troops by German officers. Under his impulse, and as an outpost of Germanic influence, Austria is put in practical possession of Bosnia.

Support of Austria-Hungary now becomes a manifest, N.C.K. 
as it had for some years been a confidential, interest of the Bismarckian system. Support only against an exacting and overbearing, not against a friendly and reasonable, Russia-the Prince would have said. But none the less it led to the offensive and defensive alliance of the German Empire and the Dual Monarchy, at the close of the Congress-to an open and avowed collapse, for a time, of the Drei-Kaiser-Bund (fatally diseased since I875) - to a temporary, yet violent breach of Russo-German friendship-and even to RussoFrench flirtations.

When Germany struck down France in I870, Russia was not merely indifferent, but prepared to attack Austria, if she went to the aid of Prussia's western enemy. On the news of Sedan, the Tsar Alexander II. drank to the health of his uncle William, and broke his glass, to ratify the toast. But 'now there came a letter,' 1 from the same nephew to the same uncle (at the height of the Berlin Congress), 'with decided menaces of war, somewhat to this effect: If you still refuse to adapt the German vote to the Russian, peace cannot last.' In view of the attitude of Russian newspapers, the increasing popular excitement, and the massing of troops along the Russian frontier, 'it would have been levity to doubt the gravity of the situation.'

Yet Bismarck had an unconquerable reluctance to identify Germanic interests absolutely with Russian. 'Tilsit, Olmütz, and other memories said, vestigia terrent.' Especially there was 1875 . And an exclusive understanding or alliance with the Slavonic 1 B. ii. 236. 
empire, even if obtainable, ${ }^{1}$ might bring with it both a renewed Austrian, and a new British, quarrel.

Thus Germany might find herself faced by the hostility of England and of the Dual Monarchy, on each side (as it were) of France-both driven or drifting into sympathy with French revenge, while a change on the Russian throne might produce the most dangerous consequences, at any moment, to a Russo-German league. Such a change, as the world knows, was destined to occur within two years, when a Slavophil son succeeded a philo-German father.

Even from $x 876$ Russian policy had become ' dominated by the war-like and revolutionary tendencies of Pan-Slavism ' - so Bismarck declared his conviction in a famous letter, which formed a charter to the Austrian alliance.

He was unable, on the morrow of the Berlin Treaty, to "resist the conviction that in the future peace was threatened by Russia, and perhaps only by Russia.' Russian feelers in the direction of French and Italian support had resulted (he believed) in disappointment, and Russian threats stood alone and unsupported; Austria (he was convinced) regarded the restless Russian policy with as much disquietude as he did himself, and seemed inclined for an understanding with Germany for common defence; while the German Empire, in alliance with Austria, would not lack the support of England-here was a point of the utmost value, and a dictum which reveals, at a stroke, a whole side of the Chancellor's policy. ${ }^{2}$

1. Before the Congress Shuvalov touched on the question of a Russo-German offensive and defensive alliance and put it to me directly.' B. ii. 242, E.T.

Cf. B. ii. 258-263, E.T. 
Yet such a German-Austrian understanding was also to have in view the cultivation of peace with Russia 'as sedulously as before.' The old Russian friendship, so priceless in I8I3-I4, in the crisis of the Seven Years War, and since the Crimea, was not to be lightly thrown away. And no sooner is the Austrian Alliance concluded (Sept.-Oct., I879) than Bismarck is watching against the dangers of its unlimited liability.

In the transports of anger with which official Russia received the decision of Berlin, and realized the fresh development of Bismarckian statesmanship, negotiations for a Franco-Russian alliance were begun. General Obruchev went to Paris, in I879, and 'sounded the leading personages.' But this tendency (a tendency fully realized, stage by stage, after Bismarck's retirement) having gone so far, is now arrested by the chief actor in the drama. Russian anger is somewhat placated; Russian susceptibilities are somewhat indulged; the friendship of the Tsar, if not of his ministers and generals, is in a measure won back. The French must wait another decade, and more, for that alliance which was 'the cry of nature, the revelation of geography, the bond of war, the balance of peace.'

So the Dual Alliance of I879, an alliance not only of two Great Powers, but of two great races, German and Magyar, was not answered by a Franco-Russian combination, even though Gorchakov was supposed to have muttered to his intimates 'I could have wished for war.'

France had other intentions; so had a considerable 
and powerful party in Russia itself. And to this inclined the calmer judgment of the Russian autocrat. Sharply as he spoke and wrote, Alexander II. was not prepared, outside moments of passion, to shatter the Prussian friendship, a foundation of his policy from the first days of his reign. And much as he disliked the extremes of German influence in Russia, the Liberator's son and heir, Alexander the Pacificator, ${ }^{1}$ the Mujiktsar, 'the Bull,' 'the Berserk,' the typical Russian nationalist and churchman, never took France to his heart till the policy of William II. left him no choice between Gallic alliance and dangerous isolation.

While guarding himself against Russian dangers, Bismarck took care to preserve a possibility of Russian goodwill. To the reproaches of ingratitude- 'votre amitié est trop platonique '-he replied, with obvious reason, that the friendship of one great power for another must always remain platonic after a certain point; for no great power could place itself exclusively at the service of another.

This was not a mere evasive expression of an old friendship turning to enmity. While Bismarck was in the saddle, the German steed never parted company with the Russian; in another phrase of the great statesman's, though the public telegraph service was interrupted for a time, the private wire to St. Petersburg was soon restored.

While, therefore, the Dual Alliance of Germany and Austria expanded into the Triplice by the inclusion of Italy (I88I-3), a Russo-German treaty, dealing with the Near East only, was concluded in I88r, despite the assassination of Alexander the father and the accession 


\section{NINETEENTH CENTURY EUROPE}

of Alexander the son. Here was a first step towards the restoration of the old understanding. And in r884, the Drei-Bund notwithstanding, Bismarck made a Re-insurance treaty with Russia. The compacts of I88I and I884 were further expanded by the agreement of 1887 , the last of the Bismarckian covenants with the Tsardom, and one of the last of his diplomatic victories. A still ampler settlement was probably under consideration, and possibly within sight, when the whole German policy, on this side, was shattered by the intervention of the young emperor, and by his challenge of the Chancellor's system, issuing in Bismarck's retirement, in the spring of 1890. William II. threw aside the Russian understanding like an old glove, and committed his country to such an unlimited support of Austria, and to such a general anti-Russian attitude, that he naturally and speedily produced a result above all dangerous to Germany and dreaded by the old German steersman-the FrancoRussian Alliance (I8gI-93).

The Russo-German relations in the eighties, the successes of the Chancellor's reconciliation policy, are especially noteworthy, when it is remembered that these were years of fierce Pan-Slavonic movement and ferment in Russia; that the Old Russian party was in power throughout this time; and that the official chief of this party, and the real leader thereof, was the new Tsar, Alexander III.

To this Emperor and his party, the Orthodox Christians and loyal conservatives of Russia, the German, as a foreigner, as a Protestant (or as a ' Latin '), as an influential trader, as an intruding resident, was 
far from welcome. The ideal of these Nationalists was the absorption, or expulsion, of every non-Russian element in the empire; and the extremists of the movement, such as Alexander's own tutor and special confidant, the famous Procurator of the Holy Synod, were ready to proceed very far on this path. Systematic persecution of inconvenient minorities, of a kind almost unattempted in most European states for centuries, and hardly at all in recent Russia, outside the reign of Nicholas I., was revived.

The German element in the Baltic provinces, and elsewhere, was one of these inconvenient minorities, one of the most suspected of these portions of foreign matter. Yet the Tsar, who, even before I890, put so severe a pressure on the German Lutherans of the Westa sovereign surrounded by apostles of Slavism and Russianization (Ignatev, Katkov, Pobyedonostsev, and the rest)-meets Bismarck half-way in a remarkable restoration of an old friendliness.

Rivalry with Britain, distrust and hatred of British foreign policy, equal distrust and dislike of British home-grown Liberalism (always ready for foreign export), a loathing for the democracy and atheism of the French Republic, all contributed to this result.

And over Alexander, as over Louis Napoleon, Bismarck exercised a personal influence by no means negligible. 'Thanks to the personal confidence Alexander III. reposed in me, I never failed to turn the edge of any mistrust aroused in him.' 1

Repeatedly and astonishingly the Tsar trusts him, and falls in with his policy, even while conscious of his

'B. ii. 279. 
own gaucherie in diplomacy, of his own inferiority in understanding. After all, he was certain that the Chancellor at Berlin would never sacrifice the Russian connection to please Vienna, to please London, or to please Paris.

The attraction of Italy into the Germanic circle was another, and not the least remarkable, of the strokes of Bismarck's later statesmanship. It is also a noteworthy evidence of the increasing value of colonial questions. By encouraging or at least assenting (like Lord Salisbury) to the French seizure of Tunis in I88I -an off-set to the British occupation of Cyprus and Egypt, ${ }^{1}$ he helped effectually to kindle afresh nationalist and imperialist spirit in Italy, and to direct the flame against the Latin neighbour, who was 'cheating' Italy of her heritage. The flame was fierce and lasting. For twenty years it maintained the heat of an effective political anger and kept the government of Rome, even for a decade after Bismarck, steady to the German League. And yet that League included the hereditary Hapsburg enemy.

'The act establishing the participation of Italy' in the Austro-German Alliance of 1879 , "under conditions which are a state secret,' was signed on May 2oth, 1882. Instead of a mere arrangement for the maintenance of reciprocal neutrality, as Austria at first desired, it guaranteed the territorial integrity of all three Powers.' But for some years, Italians complained, the treaty bore little fruit. Distrust still lingered. It was in the second period of the alliance (especially from I887), and through Crispi's efforts to make the

$$
1882 \text {, etc. }
$$


alliance an 'honestly cordial understanding,' that 'faith was born.'

'In this sanctuary of patriotism' (wrote Crispi in Princess Bismarck's album at Friedrichsruh) 'where vigil is kept for the maintenance of the peace of Europe, I leave a memory-F. Crispi-2nd October, I887.'

At the same time, and apparently as part of the same series of understandings, friendships, and pacts by which the Triplice was strengthened and deepened, and the Russian Re-insurance renewed and developed, Britain, under the first Salisbury government, was drawn into a certain association with the League of the Central Powers. This association was formed through AngloItalian agreement, guaranteeing the status quo in the Mediterranean and giving the assurance of British naval aid in case of attack from France.

'It was no easy matter,' exultantly writes Crispi's nephew and biographer, 'at a time when splendid isolation had so many supporters ... to induce British Ministers to bind themselves to a Continental power, if only by secret agreement. But Prince Bismarck accomplished this with perfect ease.' 1

${ }^{2}$ Crispi, ii. (The Triple Alliance), 162, referring especially to Feb., 1887 , and the following months. 
Colonial Matters.

The last decade of the Bismarckian age is largely concerned with colonial developments (I880-90). In these Britain is naturally, and vitally, involved on an immense scale. German beginnings, French and Russian advances, parallel efforts of other powers, produce or accelerate corresponding British movements. Yet, to the surprise of many, they do not produce an armed resistance of the old British freeholder to the intruding powers.

In most regions of the colonial and extra-European world, with the vast exceptions of the United States of America and of Asiatic Russia, Britain had the field very much to herself, from the Napoleonic age to the Berlin Congress (I800-I878).

The War of American Independence and subsequent events had limited British North America, roughly speaking, to the line of the St. Lawrence, the Great Lakes, and the 49th parallel of North Latitude. The Monroe doctrine had practically committed the United States (by 1823) against any further European territorial seizures in the New World, but the Canadian extension of the British Empire to the Pacific was (sometimes grudgingly) admitted.

Thus by 1846 the two great powers had divided their spheres from sea to sea, ${ }^{1}$ and Britain had made

1 Abandoning the idea of blocking one another's advance west of the Rocky Mountains, as by joint occupation of this California, or Oregon, up to $55^{\circ} \mathrm{N}$. (including, of course, our present British Columbia). This idea inspires the British-American agreements of 1818 and 1827 . 
good her possession of a gigantic colonial interest in North America. The Dominion of Canada (constituted by the Act of Union of 1867 , and by the additions of the North-West Territory in I869, and of British Columbia in I87I), covered an area larger than the whole of the Republic to the south, but with so huge an Arctic zone that its dimensions, for civilization and for history, were but a fraction, though a very good fraction, of the literal extent.

The island-continent of Australia had gradually become (since Captain Cook's annexation in I77I, and since the first English settlement in 1788 ) another British dominion of almost Canadian extent and possibilities. Here, however, in place of a frozen cap, was a dead waterless heart, a southern Sahara, which limited the new settlements to a coastal belt, sometimes (as in the north) almost forbidding habitation, sometimes (as in the south-east) permitting the growth of a large and prosperous community.

To the early penal centres (in New South Wales from 1788 , in Tasmania from I803) were soon added free colonization. By $1839-40$ the latter had almost put an end to the former. The gold discoveries of I850-I helped on the progress of the Austral colonies in general, and of Victoria in particular. The infant Port Philip, re-founded in 1835 , began to grow into the splendid Melbourne. The convict clearing of Port Jackson had long since developed into Sydney (I788I842). Out of the penal district of Moreton Bay, the city of Brisbane and the colony of Queensland were shaping themselves (I826-I859). And with Adelaide, in 1834-1836, South Australia had also 
commenced-a free plantation from the first. Representative government, Australian autonomy, really began with the Constitution granted in 1842 to New South Wales. And as rapidly as in Canada at this very time, representative government developed into responsible: in the four pioneer colonies of New South Wales, Victoria, Tasmania, and South Australia, as well as in New Zealand, the process was practically complete by 1854 .

New Zealand and its Maoris were not formally taken into the British Empire till I839, but the young colony, unblessed by a transportation system, yet wonderfully favoured by nature, and fortunate in its leaders, soon overtook its elder sisters of Australasia.

The native Maoris, one of the highest of the barbaric races which have conflicted with the British, made a fresh but hopeless stand for their independence between I86o and 1867. Since 1870 New Zealand's history has been that of a white man's land, and one of the most successful, healthy, and advanced of British out-settlements.

The European plantations in South Africa, since the Napoleonic age and the British acquisition of the Cape of Good Hope (I806-I815), had also grown into a little world of their own. The British rule, direct or indirect, had been steadily extended, until in the 'Seventies, and through the forward policy of the Beaconsfield government, the Transvaal on one side (in the depths of the northern Hinterland), and Zululand on another (to the east of Natal) had been annexed, or taken under protection, in 1877-79. 
The discovery of diamonds on the western boundary of the Orange Free State and the Transvaal, in I869-7I, brought fresh settlers and fresh elements from Europe. And in $187 \mathrm{I}$ the representative government granted to Cape Colony in 1854 had ripened into the full responsible government now regarded as ideal for all British colonies which were colonies of settlement, and not of mere exploitation. But the attempted absorption of the Transvaal peasants or Boers (survivors or descendants of those Dutchmen who in 1837 had migrated, in the Great Trek from Cape Colony into the heart of South Africa, in order to escape this very British rule, and live their own life after their own way) soon produced a violent reaction. On December 16,1880 , Dingan's Day-the great Boer anniversary of victorythe revolt broke which ended with the British disaster at Majuba Hill (February 27, I88r) and with the practical restoration of Transvaal independence by the Conventions of $\mathrm{I} 88 \mathrm{I}$ and $\mathrm{I} 883$.

The British Indian Empire, since the Mutiny of 1857 , had been increasingly agitated by fear of Russia-by dread lest the invader without should stimulate the disaffection within. And in the 'Sixties, as we have seen, Russian arms and influence, subduing the Central Asian Khanates, had arrived almost within striking distance of Afghanistan and northern Hindustan The age of Liberal caution and love of peace, the nonintervention policy of John Lawrence and his school passed away abruptly in the middle 'Seventies (though not so permanently as at first appeared) to be succeeded by the new imperialism of Disraeli (1874-1880). Then a determined attempt was made to expand the empire 
once more, to gain a ' scientific' frontier on the northwest, and especially to bring Afghanistan into something like definite dependence on British power, and definite hostility to Russian wiles. But the confused war which broke out with these objects in November, 1878 , ended in 1880 (after the Liberal triumph in the home elections which dethroned Beaconsfield and reinstated Gladstone) with a fairly complete reversal of policy. 'Imperialist violence' was disclaimed; there was no further talk of a British Resident at Kabul, no further idea of a veiled or open protectorate over the turbulent Afghans; an effective native ruler was installed, an Asiatic of exceptional force, Abdurrahman Khan, ' the light of the nation and religion.' Something of a British-Afghan alliance was established ; otherwise Afghanistan was put in complete political isolation: Kabul was to have no relations with other powers. All British troops were withdrawn to the other side of the mighty mountain range; even Kandahar was evacuated. Only on the side of Baluchistan, where Quetta was retained, did the forward movement of Lord Lytton's time, and Lord Beaconsfield's inspiration, leave much trace of itself.

Meantime, after her qualified success in the Near East (where until late in I88I her influence did in great measure dominate Bulgaria, and where her new Armenian gains added materially to her strength and prestige) Russia resumed her advances, and well nigh completed her conquests in Central Asia. She now attached the one remaining strip of Independent Turkistan, northeast of Persia, east of the Caspian, south of Khiva. In I88I Skobelev, the Russian soldier's hero in the Balkan War, crushed the Tekke Turkmans, storming 
Geok Tepe, their chief stronghold. Thus the Russian outposts came up to the edge of the Merv oasis, which, in spite of British warnings and protests, fell into the Tsar's hands like ripe fruit, in I884. For a moment war seemed again inevitable, when the 'Moscovites' attacked the Afghans, routed them, and ejected them from the disputed region of 'Penjdeh (March, 1884). But even this awkward incident was surmounted: everything, Gladstone informed the British Parliament, was at last ' arranged.' With extreme forbearance the Liberal government negotiated a fresh Russo-Afghan frontier, practically conceding to the Slav Empire the ' ethnographic' frontier which it claimed, from the Oxus to the north-east corner of Persia (I884-6). Except in the Pamir, occupied by the pioneers of "the great white Tsar' in I89I-95, stability and quiet were at last attained, if only for a season, "where empires met,' from the sources of the Oxus and the Roof of the World to the Caspian Sea.

But the chief colonial interest of these years-at least until 1898 -was in Africa. And here, from the year 1883 , and largely through the entrance of Germany and the fierce stimulus of her rapid and sweeping action, an accelerated movement of partition commenced which within twenty years had divided the whole of the Dark Continent among European powers.

The British occupation of Egypt and advances in South Africa (I877-82); the French occupation of Tunis and arrival on the Upper Niger ${ }^{1}$ (I88I) - to say nothing of other matters-showed a decided tendency to colonial advance on the eve of Germany's

${ }^{1}$ From their Senegal and Cape Verde base. 


\section{NINETEENTH CENTURY EUROPE}

appearance in Negroland. But it was this appearance which definitely converted a gradual progression into an excited rush, a slow apportionment into an anxious scramble, a leisurely meal into a devouring feast.

Bismarck was, it is true, a continentalist above all. His primary interests were in Europe, and on the mainland of Europe. His policy and system depended on European conditions. To sacrifice European safety for colonial adventure would have been, to his judgment, the height of madness. It is surely in this sense that he declares, during the Franco-German war, when confronted with the rumour that he meant to demand from France twenty warships, and the cession of Pondicherry- For us in Germany, this colonial business would be like the silks and sables in some noble families of Poland, who have no shirts to their backs.' Like Gneisenau in I8I5, he still felt in I870, that, without a fleet, the "possession of colonies in foreign parts would make us [Germans] dependent on the sea powers.' But it is hardly true to say, as said so often, that to the end he regarded all colonial ideas as worthless or dangerous for Germany, and that he was merely forced, against his will, to take a certain part in such a move at the close of his political life.

Such a fleet as he desired ${ }^{1}$ was founded between I873 and I883-while Beaconsfield for the last time, and Gladstone for the second time, was at the helm

1 By $188_{3}$ the third in the world-coming immediately, though at a long interval, after that of France, the latter being but a poor second to Britain. 
of the chief naval state-and at least before I88o Bismarck had ceased to be absolutely anti-colonial. From the time, indeed, that he had really founded the new empire, by the Austrian war of 1866, he appears ready to consider, though with extreme caution, certain approaches to colonial development.

But, for a considerable time, the necessary opportunities were lacking, and, in the end, Bismarck, in great measure, created them. Having obtained the needful openings he developed them to the utmost, and nearly the whole of German colonial expansion was not only founded, but actually and practically completed by the prince.

Yet, whereas, when he retired in I890, this expansion, both naval and colonial, was being maintained without antagonizing Britain, and, indeed, with increasing cordiality from the British side, the whole aspect of affairs soon underwent a sinister change under the leadership of the young Emperor who dismissed the Chancellor and wrecked his policy. Talk succeeded to action, threats to achievement;-generous opportunities were sacrificed with incredible perversity. The opposition of other colonial powers, and above all of the British Empire, was yearly made more certain. And yet, with the maximum of menace, of friction, and of danger, there was the minimum of advance.

Even before the Franco-German war Bismarck seems to have had his eye on Samoa, if not on Fiji. In these Pacific archipelagos, in nature so lovely, and in commerce so potential, he hoped, perhaps, even then to lay the foundation of a German overseas dominion. 


\section{NINETEENTH CENTURY EUROPE}

It was the coldness of the German people-and still more the opposition of their Parliament-which at first blocked his path in this matter ;-it was not the prince who held back a nation on fire for colonial adventure. Well might he say (as he did in 1876 ) that, although himself convinced that Germany ' could not go on for ever without colonies,' he failed, as yet, to perceive that enthusiasm in the nation without which he could give neither promise nor hope.

In I880 the Chancellor vainly tried to establish a German ascendancy in Samoa ; but three years later his opportunity came, in a different quarter. While Britain, under the Gladstone government of the early 'Eighties, was more and more immeshed in difficulties and dangers, and while the Bismarckian navy was completing, there had grown up in Germany a genuine colonial spirit, taking more and more a national character.

Openings for further commercial development, already so astonishing-antidotes to the Teutonic emigration, so heavy at this time-supports for political influence in the remotest regions-feeders of the growing navy and mercantile marine-diversions from parochial disputes-such were the possible colonies of the future to patriotic imagination. Reminiscences of old Hanseatic and Prussian activities were not wanting. 'As far back as the time of the Great Elector (the contemporary of William of Orange) Brandenburg had settlements on the African coast, but in the age of periwigs and gaiters they were sold.'

Beginning therefore, in 1883 , with the occupation of the arid Atlantic coast between Cape Colony and 
Portuguese West Africa, the Germans soon went on to acquisitions further north, in the Gulf of Guinea-Togoland and the Cameroons, - and further east, upon the Zanzibar coast of the Indian Ocean. Quickened by the German example the older colonial powers, to say nothing of young Italy, rushed in to secure their share of the spoil. And so, to avert war, and solve difficulties otherwise perhaps insuperable, a new Berlin Congress or Conference was summoned, not for the Eastern Question but to decide the future of Negro-land, and to settle the rules of partition (Nov. I884-Jan. I885).

At the same time the Chancellor resumed his Pacific enterprises, and in the midst of the Berlin Conference surprised the Powers with the fait accompli of a German annexation of various outlying Australasian lands-New Britain, New Ireland, and the north-east coast of New Guinea (Dec. I884).

Alarm and indignation ran high in Britain, in Australia, and at the Cape-for a season. But the diplomatic correspondence of the last four years proved fatal to the maintenance of any definite British claims. The embarrassments of the Gladstonian government were widespread and cruel-seriously in conflict as that government was with both France and Russia, if not with Turkey and the South African Boers. To force Germany into the ranks of such an army of foes and ill-wishers was eminently to be avoided. And thus the new Teutonic protectorates were soon unreservedly, though somewhat bitterly, recognised in Whitehall.

In this way a condition of strain and exasperation had for a time arisen between the old colonial mistress and the young and pushful aspirant-Bismarck pro- 
testing that Germany 'could not still maintain a friendly attitude' in Egypt if Britain 'continued unfriendly' in colonial questions-sections of the British public assuming that the mere fact of Germany desiring colonies was an insult.' 'Bizzimarck here, Bizzimarck there, Bizzimarck everywhere,' said Punch, only half in jest.

Even Gladstone's generous attitude did not at once remove the tension. "If Germany is to become a colonizing power... I say, God speed her. She becomes our ally and partner in the execution of the purposes of Providence for the advantage of mankind. I hail her entering upon that course.' The German response to these remarkable words was miserably cold and unworthily suspicious. Bismarck's personal hostility to the British Liberal leader stood in the way of better things. Yet with the return of the Conservatives to power at Westminster, with the victory of the Unionist revolt against Gladstonian Home Rule, the colonial relations of the two countries, like their world relations generally, more than recovered mutual friendliness in 1886 . Colonial jealousy in these years ${ }^{2}$ was usually of an Anglo-French or Anglo-Russian description. The struggle for the Niger was mainly a struggle between Gallic and British enterprise, skill, and resources. The manœuvres for the overland approaches to India were conducted from Westminster or St. Petersburg, from Calcutta or Tashkent.

Never perhaps had greater official cordiality existed than in these last days of the Bismarckian age. Thus the German African possessions were developed into vast geographical areas, more than four times as large
${ }^{2}$ Cf. Keltie, Partition of Africa, p. 192 (1895 ed.).
2 × 886-90. 
as the Empire in Europe, with no lack of confidence and sympathy from British authorities. Access to the Great Lakes, to the Zambezi, to the chief sources of the Nile, was secured without ' antagonizing England,' German answering support to the British occupation of Egypt was steadily given.

The transfer of Heligoland from British to German hands, a favourite project of the Chancellor's, sarcastically rejected by Lord Granville ('Spain would be equally gratified by the cession of Gibraltar ')-began to be seriously considered by Lord Salisbury. Though carried out just after Bismarck's retirement, it is really a last achievement of his policy, a last tribute to his friendship. It resulted from an atmosphere represented by some of the latest utterances of the prince while still at the helm. 'I see in England an old and traditional ally... No differences exist between England and Germany.... If I should discover that we might get out of touch with England, I should endeavour to avoid losing England's goodwill. . . Do all you can to keep good relations with the English.... It would be the height of folly to make an enemy of England.' 


\section{CHAPTER X}

FROM TRIPLICE TO TRIPLE ENTENTE-I890-I9I4

THE retirement of Bismarck was universally felt to mark a momentous change in European conditions, but only extreme pessimists gauged the depth and the tragedy of that change. The young emperor who now, in his thirty-second year, and in the plenitude of self-confidence and self-importance, took over the personal direction of the German state, proved a malign destiny for his House and Country. In his clever foolishness, his reckless rapidity, his evershifting but ever-violent purposes, there appeared, but with perplexing uncertainty, something of the unbalanced and unpractical brilliance of his great-uncle. ${ }^{1}$ Gifted with a remarkable quickness of apprehension in certain fields, and with wide interests of many kinds, with an undeniable capacity for work, and with a strong devotion to his own idea of duty (die verfluchte Pflicht was perhaps as stern a lawgiver to him as to Frederick the Great) he was yet, in certain fundamentals, the antithesis of a real statesman.

$\mathrm{He}$ was able, directly and notably, to foster the growth of German trade, industry, invention, and enterprise. But in the field of policy, in the maintenance

2 Frederick William IV. 
and development of friendships, in the management of alliances, in the avoidance of enmities, in the disarming of antipathies, his failure was colossal. Before he had enjoyed the direction of policy three full years he had already shattered the Russo-German understanding and had thus helped to create the FrancoRussian league. And after six years of his personal rule an antagonism with Britain had been created, which in its bitterness and intensity was in great measure a new thing and as sinister as it was novel.

At the time the secret was well kept, but afterwards it became notorious that the retirement of the old Chancellor was bound up with the main questions of foreign policy, and largely resulted from his refusal 'to make German interests dependent on Austrian policy.' Neither for this nor for other rash and illconsidered ends would he be the bond-servant of a headstrong novice, Kaiser or no. 'Ich kann nicht mit proskynesis dienen.' Sooner than break the bonds which united Berlin with Petersburg he was prepared to enlarge and deepen the secret agreement which had begun afresh in I88I and I884. For this purpose he was perhaps even ready to sacrifice, for the moment, the independence of Bulgaria-sure enough in his heart, we may suppose, that a Russian occupation of that country would indeed prove a Greek gift to the Tsardom.

- If Russia attempts to make good her rights (in Bulgaria), I consider it ... policy to hold simply to the Berlin Treaty.... This is demanded ... loyalty to our neighbour, with whom, whatever his prevailing mood, we must still cherish neighbourly relations.' 
But when William II. had replaced Bismarck with the obedient Caprivi, the whole of this policy was undermined, and German statesmanship surrendered itself to unqualified support of Austrian interests, dropping the Russian Re-insurance as involving 'too complicated' a system. The results of this departure from the 'old course' were immediate, definite, and perilous in a high degree. Alexander III., still halting awhile between two opinions, at last gave himself up entirely to the anti-German currents, swallowed his dislike of the republican and atheistic complexion of the State which had now become his natural political partner, and practically concluded the French alliance by the midsummer of $18 \mathrm{gr}$.

When in July of that year Admiral Gervais arrived at Kronstadt with a French squadron, the reception accorded to the visitors in itself proved the existence of a close national entente. The autocrat who had crushed republican movements at home, the conqueror of Nihilism, listened bareheaded to the French republican hymn; the French seemed as deeply moved as any Russian loyalist by the strains of Death for the Tsar.

'When in France you shall cry Formez vos.battaillons, this summons will find in Russia a joyous echo' ; with such words General Chernaiev explained to the full the meaning of the new understanding. Similar manifestations of passionate delight burst out in France. 'We have nothing now to fear from anyone' (it was declared in the report on the Budget)' we greet this dawn which rises on our destiny.'

Two years later the Russian naval visit to France, when Admiral Avellan's squadron anchored at Toulon, 
and officers and men went up to Paris), produced fresh proofs of the intimacy of the nations amies et alliées. The phrase was not used, the alliance was not officially avowed, till after the death of Alexander III. (I894). But even at the time of that avowal the secret ardour of the new love had somewhat cooled. In the fêtes of I893 Franco-Russian attachment was perhaps more fervently expressed than ever before or since. The neutral world wondered or smiled at the intensity of the French enthusiasm, and many prophesied speedy disillusion. But the league then formed continued, in spite of every adverse wind, and remained a guiding principle of continental, and later of British, policy, on to and far into the World-War, whose opening it so largely dictated and directed

For the rupture of the Bismarckian understanding with Russia, Germany could only have been effectively compensated by a close friendship, a complete agreement, or a definite alliance with Britain, with America, or with Japan-and had a real Russian quarrel been forced upon the Iron Chancellor such would probably have been his reply. But although William II. was often assiduous in the cultivation of good fellowship (which as often he blighted by some 'unfriendly' act or word) he never formed any new political tie. On the contrary, he soon proceeded to develop an English feud, as threatening as the Russian.

The quarrel of the Transvaal Outlanders (so largely British) with the Boer Republic, and the failure of the Jameson Raid, so recklessly undertaken in their interest, at the close of 1895 , called out from the German Emperor a telegram of sympathy to President 
Krüger, which awoke the deepest resentment among Jameson's countrymen. But, even before this, the young Kaiser had already alarmed and estranged all the more sober and dependable elements in the Island empire, and elsewhere, not only by his quarrel with the statesman so widely regarded (since $187 \mathrm{I}$ ) as a pillar and ground of peace, a pilot of all Europe to safe harbourage, but by the astonishing egotism, wilfulness, and provocation of his language and behaviour. Utterances breathing the very spirit of autocracy, trusting in nothing but force, and, like the Roman tyrant, careless of hate, so long as there was fear; gratuitous threatenings of unfriendly neighbours; a loud determination to 'crush all who hindered him in his work'; an alarming restlessness and instability of temperament; an intense megalomania, impelling him to direct upon himself the fiercest light of publicity and centrality-all these had been noted with alarm from the first days of his personal leadership.

His remarkable energy and unquestionable devotion to duty caused some to recollect the cynical adage of 'clerical virtues more dangerous to mankind than clerical vices,' and apply it to other cases. What would it profit to toil from morning to night, and even to manifest a Talent de Bien Faire, a Will to Do Well, if the mind were unbalanced? 'Very unstable and undependable,' comments Lord Morley on his first meeting with William II. And such misgivings were general from the very beginning of the Neue Kurs.

But perhaps it has been too seldom noticed how strangely, frequently, and often gratuitously the emperor threw away all kinds of opportunities. The abandonment of the Russian 're-insurance' 
has of course become well known, though a secret at the time; and upon this abundance of attention has been directed. But a British understanding, of a sort, and British offers of unquestionable friendliness (if of questionable right) were no less rejected-and this is still often forgotten-at the very time of the consummation of the Franco-Russian alliance. And this occurred in a sphere which the new Kaiser proclaimed as especially his own, little as he accomplished in it.

In I893 the London Government offered to recognize German 'influence' over all Central Africa between Lake Chad and the basin (not the course) of the Upper Nile-that is, up to the eastern frontiers of the Sultanate of Wadai. One object of this, perhaps the chief object, was to prevent the intrusion of French colonial activity into the neighbourhood (and still more into the valley) of the Nile. It was still assumed that Germany would be a safe and friendly neighbour, while France, it was said, had proved herself the opposite, and continued so to do. This proposal naturally implied an immense and valuable extension of the German colonial empire, on one side; the interruption or destruction, on the other, of the French ambition of overlordship 'from Mediterranean to Congo.' France protested vehemently; and the German government, making no provision for compensation, and merely stipulating for the (practically inevitable) completion of their Cameroon territories up to Lake Chad, threw aside, as in $1898-9$, the British proposals.

If Berlin hoped for a reconciliation with Paris on the strength of this, the calculation was wrong. For 
such a change, far more was needed. And when, perhaps, in the crises of 1896 and 1898 , in the heat of the Anglo-French conflicts for Lower Niger and Upper Nile, German policy had such an opportunity, the opportunity was again utterly thrown away.

With equal futility was the policy of Russian reconciliation pursued from 1895 to 1908 .

The death of Alexander III., so resolutely antiGerman and pro-French in his last years, after the snapping of the Bismarckian wires; the accession of the amiable, impressionable, vacillating Nicholas II., so averse to war, so securely attached to the most beautiful of German princesses, probably helped to rouse in the Emperor William this fresh purposeof reviving the Russo-German friendship he himself had sacrificed. To this end he cultivated, without vital advantage for himself, or for Germany, a close intimacy of thirteen years with the young Tsar. To this end he associated Germany with Russia and with France in the anti-Japanese pronunciamento of I895, compelling the new Far Eastern power to retire from Port Arthur and all her other gains on the mainland of the Chinese world. To this end, therefore, he offered up, with profound impolicy, all the possibilities of a 'Yellow' alliance, in many ways so natural and so promising for German interests.

Had the Kaiser been ready, as some of his ministers and many of his people undoubtedly were ready, to pursue this policy to a far ampler gratification of Russian and French desires, at that epoch he might at least have realized certain definite, though dangerous, 
objects, and opened the doors of immense possibilities. In such an event, Germany would have co-operated with France and Russia-with France through Russia -especially perhaps against British imperialism in all parts of the world-as in the Chinese events, the territorial seizures, the diplomatic and commercial struggles of $1897-9$; as in the Niger controversies of 1896-8; as in the competition for the Upper Nile valley, particularly in 1898 ; as in the great Boer war of 1899 .

To Count Muravev, the director of Russian policy in the most critical of these years (1897-9), such a continental coalition appears to have been a supreme ambition. To the Island empire, like many another Russian statesman, but with especial emphasis, he attributed a grasping egotism, an ambition of universal interference and overlordship, an unbounded and unscrupulous fomenting of discords. The chief hopes and wishes of the London government, he would insist, lay in an all-embracing continental war ; the safety, whether of Triple or Dual Alliance, lay in general continental friendship and co-operation. The definite accession of German statesmanship to such views would obviously have created a most serious situation, and before such a danger British policy might have been forced, as Lord Salisbury repeatedly hinted, to give way in various questions and in various regions, or else to plunge into a decisive struggle at fearful odds.

But the bankruptcy of German statecraft saved our imperialists of that time from such alternatives. As if willing to wound but yet afraid to strike, William II., after following the anti-British current to the very 
edge of the cataract, then swerved aside, at every crisis. While backing the Transvaal, apparently, with all the power, prestige, and promises at his command, against the British supremacy, down to the autumn of 1899 , he forsook his Boer clients in the final struggle, and even communicated to the British government plans for the complete subjugation of these 'clowns' (r899-I90r). While long seeming to favour, in his jealousy of the chief colonial state, a rapprochement and common action with France, he finally left her unsupported and derided in the crucial trial of strength, the Fashoda incident, and exulted in 'that second Sedan' of the hereditary foe ( 1898$)$.

And while throwing aside British friendship, once and again, to pursue the Russian entente, he steadily, vehemently, and defiantly pressed forward a policy of overt and predominant German influence (to say nothing of Austrian extension) in the Turkish Empire, which could not but keep alive the anti-German spirit in Russia, and effectually prevent the dissolution of the French alliance. He encouraged Russia to a daring forward policy in the Far East, it was believed, but left her unaided in the struggle with Japan-once more it was a question of speaking in the gate with Britain. And after the disastrous Japanese war (I904-5) he took advantage of Russia's weakness, as it seemed to many, to push forward Austria in the Balkans and help her to plant complete sovereignty in Bosnia (rgo8), thus causing a perfect and final breach of good relations with the Tsardom.

On all the chief rivals or opponents of Britain, therefore, in these years, the Kaiser produced an 
impression of cajolery and betrayal. And to the British people, and especially to British imperialism, the same impression was almost as strongly given. If he smiled on anti-British movements, only to desert them in a crisis, he declined, with equal irresolution, every chance of a British understanding, agreement, or alliance. The earlier friendship he shattered by the strange turns and the astounding indiscretions of his colonialism. In the brief and partial reconciliation of I898-99, the British cabinet, he admitted, made him offers of no small liberality and attractiveness, but he refused to profit by any of these ; Chamberlain's advocacy of a close British-German union was snubbed out of existence ; and the German Emperor celebrated the close of the century and the outbreak of the Boer war, not so much by a Samoa agreement with London and Washington as by the inception of a fresh naval rivalry.

A great German fleet, rivalling the French, had been created by Bismarck, without antagonising Britain (I873-I883); a still greater German navy, approaching the British, was now to be developed, with the utmost consequences of antagonism (I899-I9I4). Hereby the nations came appreciably nearer to the catastrophe. Abandonment of the Boers by the Hohenzollern (contrasting so strongly with the popular German sympathies), Samoa treaties with Britain, personal sympathies between Emperor and Queen, mattered little in face of the new maritime questions. For now at last British feeling was touched in the most sensitive of its nerves.

The new naval programme was introduced and accompanied, within and without the Reichstag, 


\section{NINETEENTH CENTURY EUROPE}

officially and unofficially, by language of very questionable friendliness towards the 'British cousin,' whose Boer War was even then arousing in Germany the fiercest anger; and from this time the relations of Berlin and London entered upon a new and darker chapter. Naval competition, naval challenge, naval precaution, increasingly dominated the politics and the sympathies of both states; they were the chief factors in causing the new grouping of Britain (roused from her insular aloofness), first with France, and then with Russia, against the 'Teutonic danger.'

This Triple Entente was complete by the close of I907, after the Reval meeting of King Edward VII. with the Tsar: it was aided by the personal predilections, and diplomatic skill, of the successor of Queen Victoria, the representative of views so different from the 'Germanophil ' traditions of the House of Hanover. King Edward's mother, like his father and most Englishmen of the Victorian age, however little in sympathy with Bismarck and the earlier Bismarckian policy, had always believed in the German people as the natural friends, because the nearest relatives, of the 'Anglo-Saxon.' But King Edward himself, like a rapidly increasing section of his statesmen, his thinkers, and his people, suspected in the German the tyrant of Europe, and the most dangerous enemy of the influence, the safety, and even the existence, of the British Empire. By the ententes of his reign (first the French, then the Russian) there was accomplished, in fact, what German distrust imputed to him as an ideal, an 'encirclement' of Germany.

This encirclement became still more pronounced and dangerous (no mere thing of the past, or exploded 
danger, as Prince Bülow claims) through the Bosnian crisis of I908. Already the Balkan situation had been fundamentally changed by the murder of the Austrophil Alexander of Serbia in I903, and by the installation at Belgrade of a new Russophil dynasty, under King Peter of the Black-George family. And when Austria declared, after the deposition of Abdul Hamid, the definite annexation of her Balkan provinces, and when William II. ' in shining armour' championed the advance of the Hapsburg monarchy against Serbian and Russian opposition, another important step was taken towards a general European conflict. For although the Entente powers sullenly acquiesced in the annexation, a sane German statesmanship might well have stood dismayed at the position now revealed.

The differences with Britain were plainly no lovers' quarrels, as William II. had cheerfully named them; the pursuit of Russian friendship had ended in the deepest and clearest antagonism ; France remained unreconciled and irreconcilable; the adhesion of Italy was obviously weakened (for eight years she had now been pursuing a French rapprochement); while, as if all these things were not enough, Japan had been made an enemy; and America, alternately caressed and exasperated, had been worried into a mood of annoyance and suspicion.

In I898 Admiral Dewey, returning from the Philippines at the end of the Spanish War, after hot words with Admiral Diedrichs, had declared that the 'next war' of the United States would be ' with Germany.' The German government, the Emperor himself, were commonly believed to have gone to the very edge of hostile intervention, even if 


\section{$25^{8}$ NINETEENTH CENTURY EUROPE}

the Kaiser had characteristically tried to cover initial mistakes by violent repentance. Nor was American sympathy wholly conciliated, and American distrust wholly removed, in the years that followed [1899-I9I4]. The Monroe doctrine, many thought, was in constant danger of challenge from Germany-the Imperial Germany of the big navy - whose wilder spirits so loudly and frequently proclaimed their South American ambitions.

A series of diplomatic conflicts over Morocco, and the cynical French treatment of that ancient and now harmless state-culminating in the crisis of IgII 'when we sent the Panther to Agadir'-showed afresh to what a pass Bismarck's successors had brought the Bismarckian empire. For a time, indeed, in the summer of I9Ir, that empire seemed to stand in jeopardy every hour, faced by the alternatives of withdrawal from the Morocco adventure, or war with all the forces of the Triple Entente, in a cause which could not possibly enlist the enthusiasm of AustriaHungary, strongly as she had played her part of 'splendid second' to Germany at the Algeçiras Conference of I906. Yet, through a momentary ascendancy of conciliatory tendencies at Paris, through a certain reaction towards compromise in British imperialism, and from other causes, Germany emerged with surprising advantages (as in French Congo) to balance Moroccan renunciation. And had any passable statesmanship still existed at Berlin, the situation might yet have been modified.

For on the British side, if not on the German, certain efforts were now made (it would appear) towards 
some improvement of relations. The embassy of Prince Lichnowsky to London (to mention only one incident of special importance) was marked by the opening and prosecution of negotiations which, if concluded and published, might have produced a real change in the European atmosphere. As in I893, I898, and 1899 , considerable advantages might have been won by Germany, even in I9I3, in the colonial field; and this in spite of the ever-darkening clouds of the Near East, heaped up afresh by the Balkan wars of IgI2 and the following year.

Yet, in this last convulsion, whereby the allied forces of the Balkan Christians (Bulgars and Serbs and Greeks) worsted their old Turkish overlord, and almost expelled him from Europe, lay some of the most important and pressing causes of the universal war of I9I4-I9I8. For one thing, in the general collapse of Turkish barriers, the Serbs forced their way through Albania to the sea; but Austria forbade the realisation of this hope, the opening of this window; and it was with the deepest resentment against the Dual Monarchy, and the fiercest purposes of revenge, that the invaders withdrew to their shoreless and harbourless inland realm. For another thing, the division of the spoils provoked deadly feuds between Bulgar and Serb, and animosities only less bitter between Bulgar and Greek, and Bulgar and Ruman. Bulgaria was compelled to acquiesce in far smaller gains than she had anticipated; Greece and Serbia were aggrandised beyond their earlier hopes and claims; even Turkey recovered from the Bulgarians the city and district of Adrianople; and Rumania also-without joining 


\section{NINETEENTH CENTURY EUROPE}

either in the original war of the league against the Musulman, or in the subsequent civil war of the Christian allies against one another-made substantial profit out of the 'Ishmaelites of the Balkans,' wrenching from them both the fortress of Silistria and a valuable strip of adjoining territory to the south of the Danube.

Bulgaria (conscious of her isolation, and conscious of Russian hostility to her pretensions, but also conscious of Austrian sympathy against her Serb despoilers and against the pro-Serb policy of Russia) remained sullenly revengeful, waiting for her opportunity, and ready even for a Turkish alliance to realise such opportunity.

And in spite of the new Albania, both Berlin and Vienna, to say nothing of Buda-Pest, were left by the Peace of Bucharest with the uneasy consciousnessemphasized by many a lyric outburst from their illwishers-that the whole position of the Triple Alliance, the whole fabric of Germanic influence and power had been vitally injured. The road to Bagdad, whether political or commercial, was now obviously strewn with far more numerous and more formidable obstacles ; the strength and prestige of the Turks-the chief Germanic hope and trust of recent years, beyond the Danube-had been obviously lowered; the most anti-German, anti-Austrian, and anti-Magyar of Balkan states had been especially successful, and was especially emboldened; and the Austrian frontier no longer touched Turkish territory, but only the lands of embittered Slavs who hoped for a speedy triumph of the Serb propaganda against the Hapsburg allegiance in Bosnia, Dalmatia, Croatia, and other 'Yugoslavic' lands. 
At this point it may be well, in order to complete our brief survey of recent developments, to glance at the changes in the situation of certain Great Powers, and especially of Britain, France, and Russia (so far as they have not yet been sufficiently noticed) since I878 and the Settlement of Bcrlin.

The British occupation of Egypt in 1882 -following on the overthrow of the nationalist movement of Arabi Pasha and other anti-European forces-was not in itself a sign of imperialist ambition. It was the work of that Gladstonian government which in all parts of the world gave evidence of the moderation, and even of the unselfishness and generosity of its policy. It was declared with the utmost emphasis, both by the Prime Minister and by his chief lieutenants, a temporary measure.

The retrocession of the Transvaal, the retirement from Kandahar, the accommodating British attitude in face of the new German colonial developments, the oft-repeated refusal to undertake new responsibilities in Asia and in Africa, abundantly proved, in spite of Egyptian occupation, the real spirit of our last great British liberal administration.

But with the Home Rule controversy, with the schism of the liberal party, and with the beginning of that conservative and imperialist reaction which has dominated England, at least, ever since I885, the chief colonial power entered upon a new age of colonial advance. The British liberal movement of the nineteenth century, which had first mistered the country with the Reform Bill of 1832 , closed its real victories with the Reform Act of 1885 . For the next twenty years 'Tory Democracy' and the revived 


\section{NINETEENTH CENTURY EUROPE}

imperialism were generally in power : in the short 'Gladstonian' interval, after Gladstone's retirement, Rosebery and the liberal imperialists usually controlled the party [1893-95] ; and when liberalism seemed again in possession, at the end of I905, the same process was repeated. The heirs of the Gladstone tradition succumbed, almost without a struggle, to the very spirit which it was Gladstone's work, in so large a measure, to combat and to curb.

Thus, from the commencement of the "new Cecil and Chamberlain period,' there was everywhere imperial movement, imperial expansion.

\section{- At times our Britain cannot rest, \\ At times her steps are swift and rash ${ }^{\prime} .$. .}

Burma (all that had been left from the campaigns of 1826 and 1852 ) was annexed in I886; German commencements and French advances in Africa were now balanced by British occupations, protectorates, and spheres, of vast extent. Still vaster were some of the projects now formed by such pioneers as Cecil Rhodes, in whom the new imperialism was typically expressed. After the retirement of Bismarck and the paralysis which then befell German empirebuilding in Africa, the British expansionists forced a wedge into the heart of South Central Africa ; conquered the vital positions of the Matabili and Mashona countries; divided and threw back the Portuguese counter-movements from the east coast as from the west ; ruined the 'Lusitanian' schemes of a Central African dominion from sea to sea; and even formed 
the ambition of a 'trans-continental' railway, and sphere of interest, 'from the Cape to Cairo,' from extreme south to farthest north.

On another side, the French were checked in all the lower and lower middle basin of the Niger, and throughout the Haussa states; a great British dominion, from Lake Chad to the Gold Coast, was built up by the Royal Niger Company and other agencies; and hopes were created of yet another 'transcontinental ' British sphere, from west to east, from the Atlantic to the Red Sea. On their side, however, the French renewed and redoubled their efforts. And the agreements of 1890 , giving to Britain a much reduced Niger and Haussa empire (" south of a line from Say on the Niger to Barrua on Lake Chad'), and securing the French hold on the middle Niger and on everything north of the Say-Barrua line -while England admitted her rival's claims in Madagascar-were a noteworthy success for Gallic imperialism and colonial policy. On the other hand, Zanzibar, which had almost passed under German control, was now secured by the Salisbury government from both Teutonic and French intrusion; the Germans, gratified by the cession of Heligoland, gave up Witu, and withdrew to the south of the Kilimanjaro line; and the immense possibilities of British East Africa were assured to the Island empire [I890].

In the next years Anglo-French rivalry was continued and extended. But British forward policy, while continuing (in the 'nineties), to give ground slightly in Nigeria and in the western Sudan generally, achieved impressive success in the basin of the Nile. Here 


\section{NINETEENTH CENTURY EUROPE}

the Muhammadan 'fanatical ' revival, which under its first leader, ' the Mahdi,' had triumphed over Egyptian garrisons and English influence, had routed armies, taken cities, overwhelmed heroes, was at last crushed in a series of campaigns, inspired by the Salisbury Cabinet and guided by Kitchener. The attempts of French pioneers to gain a foothold in the Upper Nile valley were unsuccessful; Marchand only arrived at Fashoda to be disavowed and recalled; and a bitter dispute threatening war was ended in the autumn of 1898 by the practical establishment of British suzerainty over the whole of the Nile regions from the Mediterranean to the Great Lakes. For Egyptian nationalism was still mute, stunned by the events of $\mathrm{I} 882$.

These results were largely due (as we have suggested above) to the collapse of that half-formed and 'halfbaked' continental coalition-German-French-andRussian - which in these years of the middle 'Nineties had made so many profitable moves on the Asiatic chess-board. Here China had been saved in I895 by the joint action of St. Petersburg, Paris, and Berlin from some of the most serious results of Japanese victory-only to be despoiled by these very saviours a few months later (I897-8). Britain, compelled to witness the seizure of Kiao-Chau by Germany, of the Port Arthur peninsula by Russia, was obliged to content herself with the harbour of Wei-hai-Wei and fresh acquisitions opposite Hong-Kong, as 'compensation.' By the 'railway agreement ' of 1899 she even recognized a kind of Russian 'sphere' in all that part of the Chinese world which lay north of the Great Wall. 
The great Boer war [I899-I90I] though calling out still more fully the anti-British temper at that time so prevalent on the continent, no less clearly emphasized the divergence of German policy from Franco-Russian, a divergence which secured Britain from one of the sharpest of her recent perils. Yet during this Boer war, and immediately after, British public opinion, and especially imperialist sentiment (for various, and above all for naval, reasons), definitely and finally went over to the creed of the 'German peril,' and prepared to make common cause with the anti-German forces everywhere. In I904 a far-reaching and deeply significant understanding, the famous Entente of France and Britain, was concluded. By this, it was claimed, all causes of Anglo-French dispute were ' amicably ended.'

France accepted, for the present, the British ascendancy in Egypt; Britain accepted, for the future, a French ascendancy over Morocco. In the western Sudan, the spheres were slightly modified in favour of France. Practically, it was understood that in the event of such a German attack upon France as it was feared William II. might launch at any moment, Britain would make common cause with her 'nearest neighbour.' It was widely hoped, and even expected, in France that some such British help would be forth coming in any Franco-German struggle.

In August, 1907, the Anglo-French entente was extended to include Russia. Surprising concessions were now made to the Tsardom in the Persian field :things almost incredible and inconceivable to the older diplomacy, a British acquiescence in Russian domination at Tehran, at Tabriz, at Hamadan, almost 
at Isfahan, resulted with astonishing readiness from another and an overmastering antipathy or suspicion. Russophobia was swallowed up in dread of Germany. On her side, Britain secured from Russia the recognition of south-eastern Persia-all the open sea-board of the Shah's kingdom, the mouth of the Gulf, and most of the province of Kirman-as a British sphere. Russia also declared her respect for the special interests of her rival in Afghanistan and Tibet.

Needless to say, Persians, Moors, Afghans, and Egyptians repudiated these agreements as outrages on the liberty and well-being of their countries.

In I908 British policy even appeared ready to support Russia and Serbia in armed resistance to Austria's Bosnian advance. If Sir Edward Grey finally acquiesced in the accomplished facts of this crisis, and accepted the Hapsburg annexation, this complaisance seems to have been largely due to the extreme unwillingness of Russia, so lately dragged through the misfortunes of the Japanese war, and torn by internal troubles, to face a gigantic European conflict. For, as in I9I4, Berlin stood by Vienna; the general conditions of the world war, at its commencement, were already at hand.

In the final and decisive form of the Morocco crisis, in IgII, Britain was again, and even more clearly, insistent on the interests of the Triple Entente. 'Plus royaliste que le Roi,' the London Cabinet showed itself for a time (it was thought) even more resolute than Paris against compromise.

France, uneasily settled under the Third Republicwith its real imitation of the British constitution and 
its superficial resemblance to the Presidential system of America--was constantly threatened, but never overthrown, by monarchical reaction, 'military dictatorship' and socialist revolution. Like the German Empire of the 'Seventies, but in a more permanent manner, the French Republic, from 1877 to I9r4, increasingly tended to oppose the Church as one of the most dangerous of its foes. 'Cléricalisme, c'est l'ennemi,' cried Gambetta, in the early days of reconstruction, and the attitude of the clergy in the decisive elections of 1877 seemed to give him only too much support. When the Republicans, by I878-9, had thoroughly mastered their opponents through their control of the Chamber, the Senate, and the Presidency, and through the resignation of Marshal MacMahon and the election of Jules Grévy, the Church fell more than ever into the cold shades of opposition and government disfavour. Primary education (especially by the laws of I88I-2) was made free, secular, and compulsory. The complete freedom of the press was declared. The State legislated afresh in the interests of the working classes. As in Britain, trades unions were permitted, the right of public meeting was asserted, the hours of factory work were restricted, some attempt was made to supervise and improve the dwellings of the poor, and machinery was suggested (and sometimes devised) for the adjustment of disputes between employers and employed.

The death of Gambetta in I882, the continued successes of the Bismarckian statecraft, and the rising influence of Jules Ferry, premier in $\mathrm{I} 88 \mathrm{I}$, and again in 1883-5, helped to turn French broodings and ambitions from European revenge to colonial expansion. 
The Republic now seized Tunis (a protectorate which balanced-and preceded-her retirement from Egypt and the resulting ascendancy of Britain on the lower Nile); the French flag was planted far more widely in Indo-China, where the conquest of Tonking and other regions was begun, not without misfortunes; France began again to claim suzerainty in Madagascar ; her pioneers reached the Upper Niger ; the foundations were laid of a great empire in the western Sudan; 'from Algeria to Congo' became a watchword of policy.

The unpopularity and fall of Ferry in an untoward generation (1885), the mood of extreme disillusion and depression which now passed over France, gave fresh opportunity, both to the Gambetta spirit of revenge in Europe, and to every school, or tendency, of anti-Republican character. General Boulanger, from I886 to I889, seemed to give force and direction to both these dangerous currents. But in I889 the General, challenged by the Republican government to a decisive trial of strength, fled to Belgium, and his ill-assorted party fell asunder. With fresh energy and renewed confidence the Republic turned to its colonial aims. Its West African empire and its Madagascar protectorate were practically recognised by the British government in the agreements of 1890 . A little earlier in the same year, the retirement of Bismarck altered the foundations of continental politics, ruining the Russo-German understanding, and preparing the way for the inevitable alternative of Russo-French alliance. In I89I, as we have seen, this alliance was practically concluded; the succeeding years of the century, on one side, saw the development of the new league, and 
on the other demonstrated the unwillingness of the Tsardom to plunge into an aggressive European war for the sake of French revenge.

Meantime, French colonialism continued to prosper. Immense advances were constantly made in Africa, where the ideal of 'Mediterranean to Congo' had been practically secured before $\mathrm{I} 898$. Daring attempts were made to secure a footing on the Upper Nile. Madagascar was absolutely annexed. The French sphere in Indo-China was greatly extended. In all its parts, the new dominion oversea was now consolidated. In spite of the Fashoda conflict with British interests, the agreements of 1898 and $I 900$ enabled Delcassé, by a radical change from Hanotaux's policy, to take full advantage of the enormous errors of German policy. Maritime anxieties in the new century, coming decisively to reinforce irritations and rivalries of many kinds, brought London into a mood of accord with Paris against Berlin.

The Entente of I904 fully consoled Frenchmen for the failure of their Nile adventure, as well as for the envenomed controversies of the 'Dreyfus case'-when the whole nation seemed torn asunder by the problems of the guilt or innocence of this Jewish army-officer; when Anti-Semitism appeared to take possession of monarchist, militarist, churchman, and patriot; when ' the honour of the army' was impugned by a famous novelist; when Zola was first condemned, and then 'enskied and sainted' ; when Picquart was first dismissed from a minor post, and then made General and Minister of War ; and when the accused 'traitor,' after condemnation to life-long solitary confinement in Devil's Island, was at last restored and advanced in 
rank, and decorated in the same military school where he had been degraded eleven years before [I894-I906].

The Dreyfus case, among other things, once more convinced the Republican stalwarts that the Church was a dangerous foe, and the main chapter of the famous affaire was no sooner closed in I899 than Waldeck-Rousseau, the new premier and leader of ' Republican defence,' opened a fresh campaign against ecclesiastical influence. The earlier struggle of I900I904 against the Religious Orders,-by which the latter were compelled to submit to state-authorization, or to leave the country,-soon widened into a greater battle for the separation of Church and State. By the laws of December, I905, and January, I907, the Concordat was abrogated; all state support was withdrawn from the Gallican Church (as from the small Protestant communions); and the very fabrics were put at the disposal of Associations of worship, to be held by them in trust for the nation.

We have already glanced at the events and movements, the currents and cross-currents, by which first the Central Sudan territories and afterwards Morocco and much of Siam were swept into the French colonial net. Long before the outbreak of the world war, the French colonies, protectorates, and spheres of influence had become (after the British) the most extensive oversea dominion of any European power. For they comprised more than four millions of square miles, and possessed a population of forty to fifty millions. France noire, it was hoped, might prove an efficient aid against Germany, a new world called in to redress the balance of the old. 
Russia, in the earlier years of Alexander III., was largely occupied with the fairly successful struggles of the Tsardom against Nihilism; with the partly successful struggles of a governmental nationalism to 'Russify' all the peoples of the empire in politics, society, and religion; and with the unsuccessful struggles of Moscovite diplomacy to maintain, if not to extend, Russian influence in the Balkans. These were the obvious matters ; the renewal of the understanding with Bismarckian Germany was perhaps at first rather more of a secret. Partly as a result of exhausting internal conflict, material progress appeared to march more slowly; the pace of railway construction, of industrial development, somewhat declined. Yet even in these years, as in the darkest epochs of the former reign, the vital growth of this great country (now adding to itself in twenty years a population equalling that of Spain) was a notable thing, a factor in modern civilization not to be ignored.

In his later years, and especially after the foundation of the French alliance, the Tsar Pacificator (here contrasting with Nicholas I., but closely followed by Nicholas II.) more and more definitely adopted a forward social policy. The 'Great Siberian railway' was at last begun in I8gr; Russia's Canada was no longer treated as a penal settlement. Serge Witte, 'Russia's Colbert,' was appointed Minister of Finance and Commerce in I892; Prince Khilkov, almost as notable a personage, became Minister of 'Ways and Communications.'

The vast French loans, really beginning in March, I889, totalling $£ \mathrm{I} 20,000,000$ even by the end of I89I, and enormously increased after that date, enabled 


\section{NINETEENTH CENTURY EUROPE}

Russia not only to fortify and re-arm-to reform and extend, in fact, the whole military system of the empire-but also to develop her material civilization in every way. The railroad network was appreciably extended, year by year. River navigation was remarkably improved. A new commercial world, centring in rapidly growing cities, began to appear.

At the same time autocracy and orthodoxy were inflexibly maintained, and Russification was inexorably pressed on. The 'particularism' of Poles, Letts, Esthonians, and Finns, of Baltic-province Germans, and even of Caucasians and Armenians, was attacked in Church and State, in education and social life. To Roman, Lutheran, or Schismatic-Greek, the same measure was increasingly applied-' compel them to come in.' The half-Teutonic University of Dorpat was Russianized; the whole educational system of the Baltic Provinces began to receive a similar imprint (I887, etc.) ; some towns even reverted (like Dorpat or Yuryev itself) to their ancient Russian names, or took new Russian forms. The severest measures were against the Jews. By various edicts, especially in I882 and I884-6, the Hebrews of Russia were excluded from public employment, restricted in access to Universities and higher schools, and in fact deprived of almost every privilege of citizenship.

Under Nicholas II., the son and disciple of Alexander III. (but with what differences of character and capacity), the same policy was pursued, both on the repressive and progressive sides [I894-I9I7].

The status of Finland, whose older Home Rule, based on the settlement of I809, had already been modified in I890-94, was still further altered in the 
sense of assimilation to Russia. The Constitution conferred by Alexander I. upon his northern Grand Duchy was practically abrogated, many thought, by the manifesto of Nicholas II. [Feb. I5, I899]. 'It cast a transforming and repellent light, declared the Finnish patriots, upon the Tsar's accession-promise, repeated from former reigns, "to confirm the fundamental laws' of Finland, 'and to maintain them steadfastly.'

Full reference has already been made to the foreign policy and the international position of the Russian Tsardom in its last age-to the estrangement of the Russian and German governments after Bismarck's retirement; to the Franco-Russian alliance and its consequences; to the Asiatic advances of the great European colonizer in the Middle East, the NorthEast, and the Far East ; to the final stages of Russian conquest in Central Asia [I88I-95] ${ }^{\mathbf{1}}$; to the beginnings of a fresh Russian advance into the Chinese world. ${ }^{2}$ It may perhaps be well to recall how Japanese resistance to Russia hardened in the new century; how this resistance was fortified by the British alliance [I902]; how the Slav empire was at last challenged and defeated, though perhaps not altogether decisively, by the Islanders of the Far East [I904-5]; how the Tsardom was nearly overthrown by the resulting discontent, depression, and reaction at home; how

1 Where the Turkomans were crushed in $188 \mathrm{I-2}$; Merv annexed in 1884 ; the Afghan frontier thrown back in $1885^{-6}$; and the Pamir plateau, the Central Asiatic mountain-knot or 'Roof of the World' occupied in $189 \mathrm{I}-5$.

${ }^{2}$ Where Manchuria was penetrated by railway concessions and other methods from 1896 , and Port Arthur, the chief naval fortress of North China, acquired 'on lease,' with the Liao Tung Peninsula, in 1898 . 


\section{NINETEENTH CENTURY EUROPE}

the crisis was partially and temporarily ended by the concession of some 'Constitutional ' government [I906] ; and how revolutionary tendencies, encouraged by the remarkable feebleness of the well-meaning sovereign, continued to gather strength until the outbreak of the World War [I9I4].

As to the Entente with Britain in 1907, expanding the French alliance into a new Triple League, facing the old Bismarckian Drei-Bund - as to the increasing tension with Austria and the new tension with Germany, so marked from the time of the Reval agreementsas to the revived Russian interests and ambitions in the Balkans, from the Obrenovich murder and the incoming of the new Russophil dynasty in 1903-and as to Russian policy before, and during, the Balkan wars of I9I2-I3-enough has been already said.

Italy, while joining herself to Bismarckian Germany, in her international policy - and while thus coming more fully within the circle of the Great Powers, of Teutonic influence, and of the central political activities of Europe-did not commit herself to such anxieties without the hope of corresponding results. Especially she began an energetic pursuit of colonial and trade expansion. Following in the wake of the German African ventures, the Rome government seized upon certain points of vantage on the Red Sea coasts (in I885) ; declared a protectorate over-Somali-land (also in I885), and even over Abyssinia (a little later); and aspired to the creation of a considerable Erythraean empire. But in 1896 the Abyssinian enterprise ended in the disastrous and humiliating defeat of Adowa, and Italian colonial aims, for a time at least, shrank 
within more modest limits. The 'aspirations' of Crispi, both in and out of Europe, had proved a heavy burden for his country. Financial deficits increased in the state budgets; taxation became even more severe, and was not lightly borne. Popular discontent became deeper and more widespread; in particular, the Triplice and the 'pro-German' sovereign became targets for criticism.

Thus revolutionary movements, especially in the north, assumed dangerous proportions, and in July, I900, King Humbert was assassinated. His son and successor, Victor Emmanuel III., brought into Italian court-politics the same 'anti-German' spirit which Edward VII. to some extent represented in Britain. The royal marriage-alliance with the House of Montenegro, sworn foes of Austria, sufficiently indicated the new tendencies, which corresponded to popular currents of increasing strength. Before the end of I902 a definite movement towards French, and away from German, friendship had begun. A treaty of commerce between France and Italy, and a French promise of a free hand for Italy in Tripoli, were among the first fruits of this movement. Already Italy was dissenting from the spirit of the Triple Alliance-though not until I9I4 from the letter of that compact.

Partly to revindicate the national prestige, so much lowered by colonial failures-partly to check the immense tide of emigration which still continued in spite of all economic improvement in the new centurypartly to forestall the dangerously competitive enterprise of other colonial powers,-partly to gratify the new imperialist Italy, however shamelessly, with additions of territory, if not of strength-the House 
of Savoy, in September, IgII, entered upon unprovolked war with Turkey, to pursue 'self-realization' by the conquest of Tripoli. In this cynical aim "Young Italy' was at last successful, having hastened the slow progress of events in Africa by a spirited seizure of the Dodecanese, or Rhodian group of Aegaean islands. By the Treaty of Lausanne (October I5, I9I2) the Turks surrendered Tripoli, their last African province, an acquisition of Soliman the Magnificent in the sixteenth century.

Thus the disintegrating process began again in the Muhammadan empire of the Levant; the miserable Ottoman defence in the Italian war encouraged the Balkan foes of the Porte to take violent action; the new league of Greeks, Serbs, and Bulgars was consolidated under the encouragement of renewed Turkish misfortune. The fresh 'crusade' began on the very day of the Treaty of Lausanne. And from the Balkan war of I9I2-I3, as we have seen, more immediately than from any other event, sprang the world-war of I9I4.

Thus for some time before the fateful year the international situation had steadily become more threatening.

To the main lines already sketched, and in some of their tracings fairly well known, we must not forget to add some important if less familiar supplementary notes.

Russia, we have seen, had been enraged by the Austrian annexation of Bosnia in October, I908. She had acquiesced, partly from caution in face of the German attitude, but partly also under the persuasion 
of a hope, and promise, that Austria-Hungary would support her in a demand for the opening of the Straits and for the free passage of Russian warships to and from the Black Sea.

And once again, Russian statesmanship believed, Austria had failed to deal fairly by her rival. That rival, accordingly, once more espoused, almost without reserve, the policy of revenge upon the Hapsburgs, of final settlement with Vienna. Russian support was now given, it would seem, to the full programme of Serbo-Croat 'liberation' and 'resurrection,' to the creation of a great Serb state at the expense of both Turkey and Austria.

The 'Ruthenians' or Red Russians of Austrian Galicia, and the Czechs of Bohemia were also encouraged to look to Russia, and to seek for union with the mighty Slavonic brother, or at least for political independence through the victory of that brother. A Russo-Bulgarian alliance was even constituted, for a time, and embodied in the military convention of December, I909. And the war of the Balkan League against the Porte apparently originated with the Serbo-Bulgarian treaty of February 29, I9I2, in which Russia assumed something of the position of protectress and arbitrator, and which was one of the most conspicuous triumphs of her diplomacy at this time. "The prospect held out by Russia, of acquiring Bosnia ... for Serbia, played a great part' in the compact-so we are told by one of the chief Serb diplomatists. 'Now the aspirations of Serbia against Austria would soon be fulfilled,' the Tsar remarked to the Serbian Crown Prince. Sofia as well as Petersburg was to help Belgrad in case of an Austrian war. 
Lastly, on the eve of the Turkish campaign, against which this treaty provided, Russia drew together more closely the ties of her French alliance. By the July of IgI2 the Anglo-French naval understanding had been enlarged into something like a maritime co-operation of all the Triple Entente Powers, through the FrancoRussian naval convention of that date. France responded to Russian wishes (and to those of her own forward school) by raising to three years the term of military service for French citizens (August, I9r3).

All the great rival Powers, indeed, now made sweeping increases in their military and naval expenditure -and strength. Russia set aside over seventy millions sterling in I9I2, as compared with sixty-three millions in IgII; Germany over sixty-four millions, as compared with sixty-two. By the midsummer of I9I4 the yearly levy of the Slav empire had been raised to 580,000 men ; the period of service had been lengthened; a standing army of $2,300,000$, it was claimed, had been provided for 'mighty Russia.' Meantime the permanent or 'peace' army of Germany had been increased to 880,000 , that of Austria-Hungary to about 500,000 , that of Italy to an almost equal figure. 


\section{EPILOGUE-THE WORLD-WAR, I9I4-I8.}

Upon a Europe thus armed, entrenched, and divided -thus honeycombed with suspicions, fears, and antipathies-prepared by so long a time of peace for the most violent reactions of war feeling-and furnished by a stern fate with so many explosive centres, powdermagazines for a reckless world,-burst the bombs of the assassins of Sarajevo.

On June 28, I9I4, the Archduke Franz Ferdinand, the nephew and heir of Franz Josef and the hope of the Dual Monarchy, was murdered in the capital of Bosnia, by certain Bosnians-Serbs in race, and accused of complicity with persons, societies, and movements within Serbia, as without her, for the overthrow of Austrian rule in all South Slav lands.

Immediately there arose a situation of deep gravitythe very thing which men had so long feared, anticipated, evaded, or postponed,- - the imminent peril of a general European war.

On July 23, Vienna presented to Belgrad her reparation demands. This momentous diplomatic note ascribed the murder to Serb propaganda against Austria, and insisted that the Serbian government should officially disavow such propaganda; should suppress or dismiss anti-Austrian publications, societies, school-teachers, 


\section{NINETEENTH CENTURY EUROPE}

army officers, and officials ; and should accept Austrian co-operation in the further investigation of the murder and its causes. Complete acceptance was required within forty-eight hours. As Serbia did not entirely submit ; as it immediately became known that Russia, in her general attitude, supported Belgrad, and Germany Vienna ; and as it was practically certain that a Russo-German war would bring France into the field, the situation became to the last degree menacing.

Austria, in response to vehement pressure, slightly extended her time limit, but on July 28 , after five days of suspense, she declared ' patience at an end,' and began war. The German government, which had at first steadily backed the Austrian veto against the interference of any other power, claiming that the quarrel was solely between the Hapsburg monarchy and the Serb kingdom, now began to show (from July 26) a somewhat different temper. 'We cannot... reject the role of mediator.' But restraining efforts were now too late.

The Vienna Foreign Office, 'disregarding German advice, and failing to keep' Germany precisely informed ' whither the Austrian path was leading,' had created a situation in which localization was no longer possible.

Russia, meantime, insisting that the Austro-Serb question was one which intimately concerned herself (as well as other powers, signatories of former Balkan settlements) was acting vigorously up to her promise, For Serbia we shall do all. Belgrad was assured of Russian support: ' under no circumstances will Russia remain indifferent to Serbia's fate,' telegraphed the Tsar on July 27. Measures for Russian mobilization, 
even by July 23, were already far advanced: on July 29 the mobilization of the whole Russian army and navy was ordered, on the German as well as on the Austrian frontiers. Two days later Germany, treating this mobilization as almost equivalent to a declaration of war (as it was indeed laid down in the original agreements of the Franco-Russian alliance- - la mobilisation, c'était la guerre ') demanded the stoppage of these preparations within twelve hours (July 3I). If not, Germany also would mobilize. Russia made no reply, and on August I Germany responded, not merely by counter-measures of mobilization, but by a declaration of war. At the same time the Berlin government required from France a definition of its attitude, and learning that the latter stood firmly by the Russian alliance, began at once the initial operations of a great western offensive.

By an error of judgment similar to that of Louis XIV. in I688, William II., his ministers, and his army-chiefs, threw their forces upon the most questionable objective. As if determined to force into the conflict against themselves the one European Great Power which in a war mainly 'East European' might have remained neutral they not only insisted upon a French campaign, and the defeat of France, as their first necessity, but even insisted on attacking France through Belgium.

On August 2, a passage through Belgian territory was demanded for the German armies, which, on compliance, would evacuate all the neutral territory after the conclusion of peace, but, on refusal, would treat Belgium as an enemy. The Brussels government, now trusting in the support of Britain as well as of France, defied the invader, and a war spirit of extra- 


\section{NINETEENTH CENTURY EUROPE}

ordinary vehemence flamed up in the Island Empire, whose participation, even a few hours before, had seemed so questionable.

The neutrality of Belgium, guaranteed in I839 by all the chief European Powers, including Prussia, had become quite a vital principle, a Monroe doctrine, to British statesmanship from that time onward. And the German Chancellor's admissions in the Reichstag on this 4th of August-that his government was committing 'a wrong,' ' a breach of international law,' but that 'necessity knew no law,'-helped materially to increase the immense antagonism to German policy which now showed itself not only in Britain, but in so large a part of the neutral world.

Thus by August 4, the Austro-Serb conflict had widened into a world-war, involving every European Great Power except Italy, with all their colonies and dependencies, from the Anglo-Indian Empire to French Morocco, German Shantung, Russian Manchuria, or Belgian Congo. From the time of Britain's entry the addition of Japan also to the ranks of the belligerents was obviously probable (it happened on August 23) ; it was not unlikely that other nations would soon be swept (and swept they were) into the tremendous struggle.

Throwing their main energies, therefore, into their western offensive, and leaving the Russian war, for the present, to their Austrian and Hungarian allies, the Germans broke into Belgium, captured Liége (by August 7) and forced the main Belgian army back to the north west, into the fortress of Antwerp, the chief stronghold of the little country. Into Brussels, thus 
left almost defenceless, the invaders poured (Aug. 20). But the main lines of attack were by the short routes from Liége to Verdun and Maubeuge, the valleys of the Meuse and Sambre.

By the sudden and unexpected storm of Namur, at the junction of these two waterways, on August 22, the Teutonic assailants advanced yet another and an important stage in their campaign, which had now given them much of both eastern and central Belgium. They now fell upon the French and British forces which had somewhat slowly come up into Hainault and were planted just within the Belgian border, mainly in positions from Charleroi to Mons ; and the Entente armies were compelled to fall back into France and towards Paris, closely pressed by the Germans. Meantime an invasion of Alsace, to which much Gallic energy had been ill-advisedly directed, had ended in failure, and long sections of the French front fell in. An attempt to rally on the line CambraiCateau Cambrésis broke down, and the western allies continued a rapid retreat towards Paris. Fearing anything like a repetition of 1870 , they carefully avoided a concentration in the capital, and took up fresh positions along an extensive line to the east of the great city. The French government itself removed to Bordeaux. At the end of August and beginning of September, I9I4, the invaders were within fifteen miles of the Louvre.

'Endure and fight' was the message of President Poincaré to the Parisians, 'while the Russians strike at the heart of the German Empire.' The Tsardom. indeed, had put out all its energies at the commencement of the struggle. Within a fortnight of the 


\section{NINETEENTH CENTURY EUROPE}

declaration of war it had thrown a million men against Austria, half a million against Prussia. The Austrian attempt at an offensive in Russian Poland was soon foiled; instead of this, there rapidly developed a Russian offensive in Galicia, which effected the conquest of the bulk of the province before the close of the first battle of the Marne.

Lemberg, the provincial capital, already in peril by the end of August, fell on September 3; Przemysl, the chief local fortress, was soon after invested; Cracow was seriously threatened. To the north, moreover, much of East Prussia, Prussia east of the Vistula basin, was overwhelmed by a similar Russian flood. Königsberg and the Vistula were approached; subscriptions were opened to reward the first Russian soldiers that should enter Berlin.

These developments naturally caused a considerable diversion of German troops, war material, energy, and attention to the eastern front, and contributed vitally to the arrest of the German offensive in France.

But, while that offensive was still rolling forward, the Russians received a terrible blow in the other theatre of war, where Hindenburg and Ludendorff almost wholly destroyed a Russian army of 200,000 men in the southern lake region of East Prussia. The seven days' fighting, to which the name of 'battle of Tannenberg ' was given, 'in memory of I4Io,' 1 marked the zenith of German fortunes in the earliest stages of the war [Aug. 26-Sept. I].

1 When Poles and Lithuanians defeated the Teutonic Order. With this began an ebb of the tide of German colonisation eastwards, the Drang nach Osten; this ebb lasted to the beginning of Prussian growth after $16_{j} 0$, under the Great Elector. 
With Tannenberg passed away the hopes or fears of a Russian 'steam-roller' crushing German imperialism from the east; with the first battle of the Marne, in the following days (Sept. 5-ro) passed away the dangers of a complete French collapse, a complete failure of British co-operation, a fall of Paris, a decisive German victory in the west.

Aided by the withdrawals of German men, munitions, and plans from western attack to eastern defence, the Franco-British forces now made a successful stand in the heart of north-eastern France, from Meaux and south of Meaux to Verdun, thus saving Paris. The invaders fell back to the Marne, to beyond the Marne, to the ridges of the 'Chemin des Dames,' to beyond the Aisne or beyond Rheims, to the northern regions of the Argonne Forest. Soon, it was hoped, they would be wholly driven out.

But on reaching a line from south of Noyon to northeast of Rheims, and the south of Varennes, the Germans found refuge in a series of positions they had prepared carefully, and here they turned successfully to bay. ${ }^{1}$ The French and British efforts to break through the 'line of the Aisne' brought little result (Sept. I5 onwards), and a kind of deadlock began on the western front, which was destined to last, and even to intensify, for years.

Northwards to Flanders each side quickly and emulously extended its forts and trenches. A last change was effected in October, I9I4, when the Germans renewed their offensive in Belgium, forced the surrender of Antwerp (October 9), and overran nearly all Flanders

1 These new positions ran slightly north of the Aisne, and slightly south of the middle course of the same river. 
and a fresh section of northern France, taking Ghent, Bruges, Ostend, and Lille, but failing to storm Ypres, to cross the Yser, or to reach Dunkirk and Calais. (October II-November 20). On the line of the lower Yser, from Nieuport almost due south to Ypres and beyond, the Entente armies, as in the battle of the Marne, made another desperate and successful rally. From the Flemish coast to Switzerland the western war had become, by the end of November, a war of 'positions.'

The German attack had been stayed along a front which protected Dunkirk and Ypres, Amiens and Compiègne, Paris and Rheims, Chalons and Verdun, Toul and Nancy-but the invaders were now masters of nearly all Belgium and of a Gallic industrial area of high value, containing nine-tenths of the iron ore and half of the coal of France. And in the Flemish harbours they had acquired important bases for naval warfare by submarines and raiders.

In the east, as in the west, the autumn and early winter of I9I4 witnessed much desperate fightinga balance of German gain in the north, of Austrian loss in the south, and a somewhat similar appearance of balance and deadlock at the end of the year. Hindenburg's first stroke for Warsaw was parried; so was the Russian menace to Silesia and Cracow ; by Christmas German and Austrian armies held Lodz ('Russia's Manchester') and the western districts of Russian Poland; the Tsar's big battalions still occupied most of Galicia, up to the Carpathians, and a narrow strip of Masurian lake-land in the extreme east of Prussia.

Meanwhile, not only had Japan entered the war on 
the side of the Entente, on Aug. 23, and taken possession of the German 'sphere ' in East Shantung, in midNovember, but in the south-east of Europe Montenegro and Turkey had both entered the combat (August 7 ; November 3).

The Montenegrins, ' noblest of Serbs,' naturally came to the support of their brethren, naturally took up arms against the secular Austrian foe; as to the action of the Porte more uncertainty at first prevailed. But it was soon apparent that German influence had been too firmly planted for any hopes of neutrality, still less for dreams of aid to Britain or to Russia. More even than the despot Abdul Hamid, the Young Turks, his 'liberal' supplanters, were the allies of Berlin.

The intervention of the Ottoman Empire on the Teutonic side immensely extended the probable or possible area of war. For the Sultan obviously threatened, and was threatened by, Egypt, Persia, Russian Asia, and perhaps even India and the Serbs. But the Turkish position was itself isolated and perilous to a degree, until the Central Powers should force a way through and join hands with Stambul. And for this, or against this, the policy of Bulgaria was important, and perhaps vital. As yet, and until the next autumn, the Bulgars remained neutral, waiting their time, watching events.

The naval side of the world war was of the first importance, but it was not illustrated by any great battle till I9I6. Germany, in opening the war, was here somewhat in the position of one surprised 'en flagrant état de concentration' ; a large portion of her 
mercantile marine at once fell into British and French hands; she had made no adequate dispositions for cruiser warfare against Entente shipping; her submarines were few and small. The predominance of the British navy in the open seas of the north,- of the French navy, aided by British vessels, in the Mediterranean-was pretty complete, from the first. An effective blockade of Germany and Austria at once began, ever increasing in stringency, ever threatening the Central Empires with severer privations. But much more than this was popularly expected-the capture of Heligoland, the bombardment of Hamburg and Bremen, a landing in Pomerania, perhaps the destruction of the bulk of the German fleet within its harbours of refuge. As on land, however, so on sea. The war revealed surprising developments of offence and defence; the protection now afforded by mines, torpedoes, submarines, and forts was so formidable that no effective near approach could be made to the German coasts.

On the other side, the offensive powers of the submarine soon began to receive most striking demonstration.

Naval actions off Heligoland (in August), off the coast of Chile (where German cruisers destroyed a small but powerful British squadron, in November), and off the Falkland Islands (where the same German cruisers met their fate at the hands of a British fleet, in December) - the chief events of formal naval warfare in I9I4-were of no decisive character.

The first campaign had been marked above all by a great German offensive in the west; to this the 


\section{THE WORLD-WAR, I914-18}

Austrian disasters and the German defensive-offensive on the Russian front had been subsidiary.

But in the next year (IgI5) the outstanding development was unquestionably the German-Austrian offensive in the east. The results of this were so momentous that for a time it seemed as if the whole issue of the war might here find its decision. But for the bankruptcy of German statesmanship this appearance might have proved not altogether deceptive. 'Eastern war: western diplomacy'-along these lines alone could Germany hope to escape disaster.

The new chapter began with Hindenburg's sudden attack upon the Russian divisions encamped just within the East Prussian frontier. This 'battle of the Masurian Lakes' concluded with an encircling movement, around the Augustovo woods, which produced another Tannenberg, a humbler Sedan,- ' II0,000 prisoners and hundreds of guns' (Feb. I2). The great bastion of Russian Poland was now more seriously threatened: the pressure towards Warsaw increased. During much of the spring, and especially during April, the Grand Duke Nicolas on his side vainly struggled (at immense cost to his enemy, and to his own Russians) to force the Carpathian passes, and to pour his hosts into the Hungarian plains. All this time the aforesaid enemy was preparing a counter-stroke-the heaviest and most effective blow of the year.

Still on the eastern side of Europe, but further to the south, desperate and fruitless attempts were made, beginning in February, first by naval forces alone, then by land as well as by water, to force the Dardanelles, to strike at Constantinople, and to paralyze the Turks.

N.C.K. 


\section{NINETEENTH CENTURY EUROPE}

Not till the December of I9I5-after the 'elimination' of Serbia and the junction of Teuton, Magyar, Turk, and Bulgar in the Balkans-did the Entente abandon their Hellespont enterprise; often during the year high hopes were entertained of ultimate success; but the alluring prospect proved always a deception. The naval misfortunes of March I6-the sinking of the Bouvet, the Irresistible, and the Ocean-were only too significant of the future.

On the west, meanwhile, no decisive change was effected by fierce onslaughts from either side:-at Neuve Chapelle the British, in early March-in the ' second battle of Ypres ' the Germans, in later Aprilgained a little ground (March I0-12 ; April 22-26). In the Flemish mêlee poison-gas was now first used by the attacking Teutons. But the results were only local twistings and bendings in a front of more than 400 miles.

At the end of April, the Russians (who held the Carpathian summits on April gth, and still fought for Carpathian control three weeks later) announced their readiness for a sweeping campaign of victory and conquest. But on May 2 and 3 'eastern fortune' declared itself decisively in the opposite direction. At the head of a vast body of German and Austrian troops, carefully organised and equipped with most powerful artillery, General Mackensen broke the Russian front in Western Galicia. Here, in the battle of the Dunajec, the Moscovite centre was not merely defeated, but destroyed; and retreat, surrender, disorganization, depression, and even a creeping paralysis of fighting energy and patriotic spirit, followed one another in the sad story of Russian failure and Tsarist ruin. 
By the middle of May the whole of the Carpathian highlands had been abandoned, and most of Western Galicia, almost up to Przemysl ; by the end of May Przemysl itself was doomed: the fortress fell on June 3. ${ }^{1}$ And although, on May 23, the Italian Government had at last completed its change of front, and from unfriendly neutrality had passed to open hostility towards its old allies of the Triplice, the course of the campaign continued to run in the same channel.

During June the Tsar's armies were driven out of all Central and Southern Galicia; Lemberg was captured on June 22nd ; the 'Polish Bug' was reached on the 27th; then Mackensen began to swing round northwards. The Polish 'redoubt' was now to be attacked from the south, as already from the north and west.

In all this time there was a development of the same offensive in the north and north-east. Courland was invaded, and in large measure overrun: Libau, with its ice-free Port Alexander III., was taken (May 8). The German attack, to the north of Warsaw, on the line of the Narew and elsewhere, grew stronger, while on the west, between Lodz and Warsaw, there was no lightening of the strain. Throughout July the triple pressure steadily increased upon the Central Russian salient, against all the three western fortresses of the Polish Quadrilateral, ${ }^{2}$ and at the end of the month this defence began definitely to crumble. First Ivangorod, then Warsaw itself, then Modlin or Novo-Giorgievsk,

${ }^{1}$ It had only been taken by the Russians in the preceding March, after a long siege-since the September of I9r4.

2 I.e. (I) Warsaw, (2) Ivangorod, (3) Novo-Giorgievsk, (4) BrestLitovsk. 


\section{NINETEENTH CENTURY EUROPE}

were abandoned or cut off, at the beginning of August. The Russian front fell back, suffering terrible losses, to Brest-Litovsk and the line of the Polish Bug, on the frontier of Russia proper. Even this could not be held ; Brest was captured on August 25; and everything up to Pinsk (in the heart of the vast marshes of the Pripyat) - to beyond Vilna (the Lithuanian capital, taken on September I8)-and almost to Dvinsk and Riga, ' half way from Tannenberg to Petrograd'-in all an area larger than the British Isles-was occupied by the foe. More than a million Russian prisoners, it was claimed, fell into German and Austrian hands in this retreat. The very foundations of the Tsardom, as it proved, were undermined, and the complete evolution of a new Russia, at so many points conflicting with the old, was almost visible. ${ }^{1}$

At the end of September the German command turned its attention from Russia to the Balkans, where the siege of Constantinople, or in other words the 'Gallipoli battle,' was still undecided. Austria had disgracefully bungled in its first Serbian campaign (especially in December, I9I4). A fresh trial was now to be made, with Teutonic help, under Teutonic leadership, and with the certainty of Bulgarian co-operation, doubly assured since the practical failure of a fresh Anglo-French attack in the west in late September. ${ }^{2}$

Mackensen now led 400,000 Germans and Austrians against Belgrad and Nish; the White City fell on the 9th and Ioth of October; and at the same time Bulgaria fell upon Serbia in the east. Before Christ-

1 Thus Brusilov, the ablest of the Tsarist generals, now began to be a 'Republican at heart.'

' 'Battles of Loos,' 'Tahure,' etc. 
mas the assailants had united their forces; had swept over the whole Serb land, even to Monastir; had driven the remnants of the Serbian armies into Albania and through Albania towards the Adriatic; had begun the conquest of Montenegro; and had joined hands with those large sections of the Arnaut tribes friendly to Austria and hostile to Italy, or at least attached to Islam and the Caliph at Stambul. Germany and her allies now commanded a Mittel-Europa from Bruges and Bremen to the Bosphorus, and a Western Asia as far as Baghdad, Erzerum, and the Persian bordermountains. The Dardanelles adventure was perforce abandoned. In the last weeks of I9I5 and the first days of the new year the rest of Montenegro was overrun.

Almost at the beginning of the Serbian peril an AngloFrench force had been brought to the aid of these 'guardians of the gate,' by way of Salonika, at the suggestion and invitation of an enthusiastic and veteran partizan of France and Britain, the Cretan lawyer Eleutherios Venizelos, then chief of the Hellenic Cabinet, and the most prominent of Greek statesmen since rgIr. But the co-operation of this force was at first ineffective (October, I9I5); Constantine, the King of the Hellenes, who was not only the idol of the Greek army, but also the husband of a Hohenzollern, William II.'s only sister, refused to endorse the policy of Venizelos; and the Entente Governments, unable even to prevent the fall of Monastir, and obliged to withdraw their troops behind the lines of Salonika, could only give effective aid to the wreckage of the Serb army when it reached the Adriatic coast, ready to be transported on shipboard to a new refuge in Korfu.

Meanwhile the Turkish entry into the war had also 


\section{NINETEENTH CENTURY EUROPE}

produced, on one side, a threat, or feint of attack, against the Suez Canal, which had no serious outcome ; on another, an Anglo-Indian attack upon the head of the Persian Gulf and upon Mesopotamia, which led to some remarkable developments.

Early success-in the occupation of Basra and the lowest reaches of the Euphrates and Tigris-led on to the first Baghdad enterprise. It failed lamentably, and the inadequate British forces, after reaching the very neighbourhood of the old city of the Caliphs, the Abode of Peace, were compelled to make a rapid retreat, and were cut off and besieged at Kut-ul-Amara, almost Ioo miles lower down the Tigris.

Against so many disappointments in this year the Entente cause had at least the encouragement of colonial success. Many of the German oversea territories-their Pacific islands, their Shantung sphere, their Cameroon and Togoland, most of their SouthWest African possessions, were easily conquered. But a resistance of remarkable skill and tenacity was shown in German East Africa ; at the very end of the war some embers of this fire continued still to glow.

To the naval blockade of Germany and Austria, the German government replied in February, 19I5, by proclaiming a blockade of the British Isles, to be effected by submarine warfare. All Entente ships found within the 'war-zone' were to be torpedoed without warning, and neutral ships and nationals could only cross that area at their own r.sk. By the beginning of May more than sixty merchantmen, including some neutral vessels, had been sunk in the British seas; and on May 7 the great Cunard liner Lusitania was sent to the bottom of the sea, off the 
Old Head of Kinsale, near Cork, with a sacrifice of nearly I200 non-combatant lives, more than a hundred of them American. Thus a state of acute tension developed between Germany and the American people, if not between the two Governments. Clinging desperately to ideals of peace, neutrality, and final mediation, President Wilson and his Cabinet, while conscious of the 'sacred duty of maintaining the rights of the United States' did not go beyond demands for disavowal and reparation; resisted the warlike pressure of strong currents within and without the Republic; and while addressing diplomatic notes to Germany against submarine excesses, likewise addressed notes of protest to Britain on certain incidents in her blockade. The year therefore ended without any agreement on the character of the submarine campaign: but it became increasingly clear that if America were to be kept out of the war some such understanding must be reached.

At the end of I9I5, at the opening of I9I6, the fortune of this war was perhaps more favourable to Germany than at any time before or after, but, as before and after, political advantage was not taken of military success, and the operations of the armies were very partially and inadequately directed by statesmanship. Often indeed the real direction of policy seems to have rested in the hands of military and naval chiefs : the Chancellor Bethmann-Hollweg had drifted like a rudderless ship into war, and like a helpless wreck he drifted through the war. And in all this conflict the Emperor William, so far as he can be regarded as a sane intelligence at all, was fatally ' militarist.' 
These radical defects were revealed afresh in the campaign of I9I6. With so many possibilities of promise before her, Germany chose the one field where a fresh offensive was almost hopeless. With such imperative need of moderate and conciliatory spirit and of diplomatic skill, she displayed a consistent lack of all such qualities. And before the close of the year, pursuing to the utmost the falsehood of extremes, she had decided upon a line of action in naval matters which did not make success attainable, but defeat inevitable.

So, instead of aiming the next blow at Russia, or at Italy, or at Mesopotamia and the Middle East (in all of which directions there were possibilities of the most alluring kind for the Central Powers) the Berlin government, with extravagant hopes and ideas of Gallic exhaustion and depression, struck at France, and at one of the most powerful of all French fortresses. On Feb. 2I, I9I6, a great attack was launched against Verdun, standing somewhat in a salient of the French front, but in a position of immense strength, and one which the western allies were resolute to defend at any cost. Though a pretty large belt of ground (about eighty square miles) was won in the first five days of the offensive, the subsequent advances of the enemy, made at enormous sacrifice throughout April, May, and June, were in pace extremely slow, and in extent very small. On February 26 they had advanced to within four miles of Verdun city; by their last successes of June 23 (such as the capture of Fleury) they completed a further advance of one mile. And now they were too late, for Verdun was effectually saved by the AngloFrench offensive a week later, beginning on the first of July, Igr6. 


\section{THE WORLD-WAR, I914-18}

Meantime, in the eastern theatres of war, Russia gave fresh though perhaps deceptive signs of life, not only in Europe, but also in Asia. In Armenia, in the most severe conditions of winter upon that terrible highland, a vigorous blow was delivered against the Turks, and Erzerum was taker (Jan. II-Feb. I6). But although further progress was made, and the useful seaport of Trebizond, among other points, was captured on April I8, disappointment finally settled upon this, as upon so many other Russian efforts, and no general or decisive Turkish collapse ensued.

All this while ten thousand British and Indian troops remained closely besieged in Kut-ul-Amara on the Tigris, and in spite of the Armenian operations, and notwithstanding all attempts at relief, this force was at last obliged to surrender on April 29, rgr6.

As if the wastage of Verdun were not enough, the Central Powers attempted another western offensive, which (however promising in earlier months, and as their main enterprise) was evidently perilous, and worked out as practically disastrous, in the circumstances of May and June, r9I6. This was the attack upon Italy from the Trentino-undertaken by Austria alone, at the price of a dangerous weakening of her Russian front, and at so late a period in the year that the western allies had notoriously been afforded time and opportunity to put new life (and war material) into Russia. The energies which might have completed the defeat of Russia were thus diverted to the French and Italian fronts, and the statesmanship which might have guided towards peace left the helm to the steering of military misconception. So, after prosecuting an onslaught upon northern Venetia for a fortnight (May I5- 


\section{NINETEENTH CENTURY EUROPE}

June 4), and after accomplishing an appreciable advance towards Verona and Vicenza, the Austrians were first stopped, and then recalled, by a new Russian attack on the Galician side; by serious breaches in their eastern line; and by humiliating losses, threatening a repetition of the early disasters of the war.

But for timely German aid the whole of this Austrian front, the whole line south of the Pripyat Marshes, might have collapsed. As it was, serious damage was sustained-and Russians again mastered the fortresses of Lutsk and Dubno, the city of Czernowitz, all the Bukovina province, and a fresh strip of Eastern Galicia (June 4-June 30). But the bulk of the Austro-German 'recoveries' of I9I5 were still held-though not without German aid, apparently the almost indispensable accompaniment to permanent Austrian success.

Meantime, at the end of May and beginning of June, the monotony of the naval blockade (so uneventful, but so important) was at last broken by a sea-fight on the grand scale, but as no immediate or vital change was thereby effected in the fortunes of the war, the 'battle of Jutland ' may be noticed somewhat later.

The Russian recovery in the East had been in evidence a full month when a parallel enterprise, long expected, ardently desired, and greatly trusted, began also in the West. This was the Anglo-French offensive in the basin of the Somme, from near Arras to near Montdidier. Planned on a gigantic scale, adequate at last, it was hoped, to the mighty work before it-no mere local effort, but a national exertion of Britain and France upon the central problems of the war-it yet resulted, like the Verdun attacks, in ultimate dis- 
appointment. Again and again renewed, the 'battle' lasted into November, but by the end of July it was evident that 'neither British nor French were advancing at the speed necessary for the attainment of any dramatic success.' The ground won by the Entente upon the Somme in 1916 was about equal to that won by the Germans around Verdun-a hundred square miles, or a little more. One solid gain resulted from the stupendous Franco-British effort-the pressure on the great Lorraine fortress was finally relieved.

Meantime the Russian onslaughts in Galicia continued with much fury and some slight success ${ }^{1}$ until the early days of August. But from the time that Rumania entered the arena Russian co-operation became again astonishingly feeble. The leaven of revolution was beginning to work. And just when it might once more have changed the history of the world, the Tsardom stood almost apart, a spectator rather than a combatant.

The intervention of Rumania proved another miscalculation-one of the most tragic of the war. 'It was naturally believed that at last the German armies would give way, and the flood of the Entente millions would surge through the gaps.' But the result was otherwise indeed. The Somme offensive had worn itself out: Russia, partly exhausted and partly dispirited, was already deeply affected by the fever of revolution, and that a revolution frankly hostile to the 'war-spirit'

The chief objective of the Rumanians was not Constantinople (as some expected, and as policy might

${ }^{1}$ Brody. for instance, was taken. 
have dictated), but Transylvania, the Rumania Irredenta beyond the Carpathians. The whole autumn campaign (till mid-October) offers a certain parallel to the French invasion of Alsace-Lorraine at the beginning of the war.

Within ten days of the commencement of hostilities on this new front, the Austrian and Hungarian troops had fallen back from the mountain barriers of Siebenburgen, from its chief towns, and from most of its eastern and southern districts (Aug. 27-Sept. 6). But before September 25 the tide had turned again.

The Rumanian decision had caused a fundamental change in German military command and strategy, though not in the higher fields of statesmanship. And this change implied a decided renewal and increase of German fighting efficiency. The partisans of Westernism-those who, like Falkenhayn, had sought for decisive victory on the Gallic front at all costs, and to the neglect of other possibilities-now gave way, under the double discredit of Verdun and Rumania, to the impenitent Easterners, Hindenburg and Ludendorff, to whom the triumphs of 1915 had been so largely due, and whose eyes were still mainly fixed upon the same theatre of conflict. On August 30, 1916, 'Marshal von Beneckendorff and Hindenburg' became Chief of the General Staff, and General von Ludendorff Quartermaster-General. The most vigorous measures were taken by the new leaders to meet the new dangers.

So, while the Rumanian advance was apparently progressing with all good fortune in Transylvania, a powerful Bulgarian and Turkish force, with a German contingent, had been collected to the south of the Danube, under Mackensen. And on September 6 this 
army suddenly moved forward. Within a week it stormed Tutrakan and entered Silistria, the chief borderfortresses on the Dobruja - and lowest Danube-frontier (Sept. 6-1o). Ten days later the Rumanians also began to fall back on the side of Hungary; Mackensen was pressing on to the unique Rumanian port of Constanza; the whole situation was altering (Sept. 20-25). At the end of September definite disaster began to overtake the invaders of Transylvania. In the first half of October these invaders mostly retreated to their own frontiers, and Rumania itself was threatened with invasion on both sides. For weeks, however, the 'Romans' maintained a desperate defence of the Carpathian passes, though unable to prevent Mackensen from mastering almost all the Dobruja and seizing Constanza (Oct. 22, I9I6). Gradually the passes also were lost; before mid-November the Austro-German army had forced its way through the mountains, and pressed down into the Wallachian plain; in the battle of Tirga Jiu the Rumanian left was broken (November I4-I6); and hereupon Mackensen effected a junction with his comrades by a brilliant passage of the Danube. The united armies of the Central Powers now pushed on rapidly and irresistibly. Bucharest itself was soon enveloped from north-west to south; Russian attempts at succour were ineffective; by the battle of the Argesu the fate of the capital was sealed (Dec. 2-3); and on December 6 the city fell.

Still rapidly retreating, the Rumanians now abandoned Wallachia altogether, falling back to the Sereth and the Moldavian border, but putting out of use, to the utmost of their power, their famous and priceless oil fields. 
During the whole of this extraordinary campaign, no effective diversion was accomplished in the West. Although the Anglo-French attacks again and again started into fresh life, these Herculean labours failed to alter the general position.

Naval operations in IgI6 were chiefly marked by the definite stand of the American Government against ' unrestricted' or 'indiscriminate' submarine warfare (in March) ; by the German acceptance, temporary and misleading as it proved, of the American contention, at least in its main lines (in May); by various incidents of submarine and raiding warfare; by the increasing pressure of the British naval blockade upon German supplies, prosperity, and comfort $;^{1}$ and above all, by the one great maritime action of the war, the battle of ' Jutland,' 'Horn Reef,' or the 'Skagerrak' (May 3I-June I).

This last was apparently the result of a German attempt to cut off a section of the British fleet, and destroy or cripple it, while avoiding an action with the rest. 'It was obvious that, if this strategy could be repeated with success on several occasions, it would become possible for the German navy to make a serious bid for the command of the sea.'

In the narrower sense, perhaps, Admiral Scheer attained his object. Admiral Beatty and Admiral Hood, dashing to cut off the Germans with their battle-cruiser squadrons, and heroically prepared to

${ }^{1}$ Thus on July 8 , 1916, the British Government withdrew its adherence to the Declaration of London (proclaimed on August 20, 1914, but never ratified by Parliament) and adopted instead new and more stringent rules as to continuous blockade, contraband of war, and the other incidents of such a naval war. 
take the utmost risks if only they could force a general engagement, suffered severely. Hood perished with his ship ; and three of the most powerful of the British battle-cruisers were sunk, with all their crews, while the German flotilla, after two hours' running engagement with the main British fleet under Admiral Jellicoe, escaped to harbour with somewhat slighter injuries than its opponent. "Having regard to the size of the fleets engaged the losses were small .... The battle was inconclusive, neither side being able to claim anything in the nature of a final victory.' In so far, however, as the British navy still kept the mastery of the North Sea, and as the Jutland experiment was not repeated, the advantage rested with England. In so far as comparative prestige was concerned, the Germans might boast of a measure of success ; no young maritime power, perhaps, would have done otherwise. For had they not mauled the leading navy of the world more seriously than anyone since the days of Van Tromp and De Reuter?

As the Rumanian struggle moved towards decision, the central interest of the war shifted for a time from arms to diplomacy.

Immediately after the fall of Bucharest, the German government made a definite public proposal, through the 'speaking trumpet' of the Reichstag, and by the mouth of the Chancellor Bethmann-Hollweg, for the opening of peace negotiations (Dec. I2, IgI6).

In this proposal the allies of Germany united, and through the agency of certain neutral powers-Spain, Switzerland, and the United States-a diplomatic note embodying the suggestion was forwarded to the 
Entente Governments, which speedily and summarily rejected it. Thus French statesmen treated it with scorn; and the new British Premier, on the same day, in the House of Commons, declared his 'trust in an unbroken army rather than in a broken faith ' (Dec. I9). The doom of Bucharest had also been the signal for a successful revolt in Britain both against Asquith himself and against the compromising tendencies he was supposed to represent. Lloyd George, the zealous and successful Minister of Munitions and of War, now became head of the Cabinet, with the avowed object of a more effective prosecution of the struggle (Dec. 7).

But, a few days later, Woodrow Wilson-who for some time had been tending towards the attitude of a mediator, and who had just been re-elected President of the United States-addressed a note to all the combatants, calling upon them definitely to state their chief war-aims, and peace terms, and declaring that the 'objects' of both sides were 'virtually the same' (Dec. 20, I9I6). Annoyance and resentment at the President's action were freely expressed in the Entente countries, and there was a general refusal to discuss any such proposal. On the other hand, the German government, while professing to welcome the American suggestions, gave no specific information about terms or aims (Dec. 26, I9I6). This evasive answer produced an unfavourable impression; it showed, some thought, that the peace offers of December I2 were but a 'theatrical gesture ' for the benefit of German public opinion. None the less, the prospects of peace were now brighter than they had been throughout the war, and Count Bernstorff, the German ambassador at Washington, with a true insight into the interests and necessities 
of his country, vehemently urged the co-operation of Berlin with Washington, especially in regard to guarantees for disarmament, arbitration, and a peaceleague.

Thus-with an apparent dawn of a more peaceful day-opened the year I9I7. The dawn was not long in revealing portents of a fresh storm ; the ruddy sky, with its too early promise, again proved a warning indeed.

For, just as Woodrow Wilson was renewing and increasing his efforts towards a general accommodation, the German government apprized Bernstorff that an ' unrestricted' submarine warfare, even against the merchantmen of neutral Powers, had been practically decided, and would be speedily begun (Jan. 4-5, I9I7). And despite the ambassador's warning that 'steps in this sense' would cause the collapse of 'Wilson's peace-effort,' and bring about a rupture with America instead, the decision to declare ' ruthless' submarine warfare (as from February I) was taken on January 9, at a Council held at Pless in Upper Silesia. As a result of this supreme act of political insanity, the United States were at war with Germany by April 6 . A new world was thrown into the scale, to redress the balance of the old.

Meantime, on the other side of the world and of the war, an eastern power was wearying of the conflict as this western recruit entered it. Accession and defection were alike on the largest scale. When Russia overthrew the Tsardom and declared a republic, in which from the first appeared a strong tendency towards peace-when Nicolas II. abdicated, deserted 


\section{NINETEENTH CENTURY EUROPE}

even by the army (March I5, I9I7)-a monarchy and an imperial system were ended which had been, for three centuries and more, one of the most extensive and imposing of Christian states and world-powers. But when the United States came into the field, so mighty a force was set in motion that even Russian failure was compensated.

All the influence of America was now thrown into the scale of the Entente. Had President Wilson been of the same mind in the spring of I9I7 as in the December of I9I6, a Russo-German armistice might have been one of the first results of the Moscovite revolution. Even as it was, pacifism gained in influence from day to day in the new republic. Thus in the middle of May Paul Milyukov was compelled to resign the Foreign Office, as an imperialist who obstinately cherished the Tsarist ambition of a Russian Constantinople. The spirit, and the very watchwords, of the American President some months earlier (though now repudiated at Washington), seemed to become the possession of Russian democrats. 'Peace, without annexations, and without indemnities,' found a new home. And even Kerensky, on whom the waning hopes of the Entente came chiefly to repose, and who increasingly dominated the new Russia, for a time, as Minister of War-while opposed to any separate agreement, or Russo-German treaty, was in favour of a general accord, a general forgiveness and oblivion, without changes of territory or punitive payments.

But until the disasters of July, I9I7, the allies of Russia seem to have realized these changes but imperfectly, and with the New World in 'association,' if not in 'alliance,' a speedy victory was confidently 
expected. Such hopes were quickened by the British rally in Lower Mesopotamia, by the fresh invasion of the Tigris Valley, and by the capture of Baghdad (February-March, I9I7).

Still more a momentary and natural exultation was felt over the German 'strategic retreat' from their French bastion in the south-west to a shorter and straighter front-from the Arras-Noyon-Laon curve to the Hindenburg Lines (March-April, I9I7). This involved the evacuation of a really considerable block of territory-over Iooo square miles-and the deliverance of some 300 towns and villages. Bapaume, Peronne, Ham, St. Quentin, were all restored to France. But the whole of this region was systematically wasted, and its communications destroyed ; the Germans, it soon appeared, had retired to prepared positions of exceptional strength; and the Franco-British attacks, from April onwards, failed to yield any further gain of a decisive character. Nothing but small local advances resulted from a colossal expenditure of effort, of munitions, and of life. The steady weakening of Russia enabled Germany to transfer immense reinforcements to the Western front; American aid was slow in arriving; and the ruthless submarine campaign soon caused increasing interruption to Entente communications, and an alarming diminution of available Entente resources. Midsummer found the western theatre (like the eastern) essentially unchanged from Easter.

After midsummer came some of the chief surprises of the war. Russian war-spirit had been evaporating for some time; it now disappeared. The July offensive, to which Kerensky had at last stimulated (in theory) certain portions of the Galician front, 
ended almost immediately in collapse, and in a further retreat. Even the easternmost strip of Austrian territory (Tarnopol and the rest) which had been in Russian hands since the commencement of the war was now abandoned (July-August). Then the northern front was broken, the Dvina crossed, and the great city of Riga captured (Sept. 3). South-western Livonia, and the islands of Dagö and Oesel, commanding the entrance to the Gulf of Riga, were also overrun by the Teuton fleet and army of the Baltic (Sept. 3Oct. 23).

This advance, it was feared, would soon reach Petrograd. Such fears were not lessened by the Bolshevik mastery of the Russian republican government at this time (Nov. 7). Hereby the extremist wing of Russian radicalism gained supreme power, and with the advent of Bolshevism an early Russian retirement from the war became a practical certainty. Pacifism and internationalism, as much as socialism itself, were watchwords of the new Soviet party. Meantime, how easy for the Germans to break down the relics of resistance, and to 'hack their way through' to the Neva.

But just as this seemed to become obvious and inevitable, Berlin (and Vienna) chose another objective. Leaving the dissolution of the Russian armies to be completed from within, the German command sent an important contingent to the aid of Austria against Italy. The Central Powers threw their Trieste battalions, thus reinforced, upon their foes in the Isonzo basin and on the western edge of the Carso upland. By a fierce and sudden dash they broke the Italian lines (especially in the action at Caporetto) and threw 
back the defenders of Venetia behind the border mountains, and across river and plain, almost to Venice itself (Oct. 23-Nov. Io, etc.). Udine and all Friuli were occupied; so was the region of the Venetian Alps, larger than Kent or Sussex.

Meantime all the efforts of the Entente on the French and Flemish front, in the latter as in the earlier months of I9I7, had effected no fundamental change, since the Germans took up their new positions on the Hindenburg Lines. Some ground was gained near Ypres (and especially the ridge of Passchendaele)some on the Aisne front, near Vauxaillon-some near Cambrai-although in the Cambrai sector much of this was lost again. But in the main the opposing trenches lay-from the Flemish coast to Switzerland-as they had lain since December, I9I4, save only for the salient evacuated by the Teutons in the spring of r9r7.

In Asia, however, there were important changes in this year-not indeed decisive, as on the Russian front, but still not inconsiderable. In February and March (as already noticed) a fresh British advance in Mesopotamia, under an abler leader, General Maude, and with far better preparation and equipment, recaptured Kut-ul-Amara and took Baghdad (February 24; March II). And in the autumn and early winter another Asiatic offensive by British armies, under General Allenby, from Egypt into Syria, gradually developed into brilliant, if partial, success. On December ro Allenby reached and occupied Jerusalem, and the year ended with a 'stillstand' on a Samaritan front.

Nothing marked the struggle of I9I7 more luridly than the new and desperate phase of naval war. For 


\section{IO NINETEENTH CENTURY EUROPE}

a time the German 'ruthless' submarine campaign steadily increased its effectiveness in both directionsthe destruction of Entente shipping, and of neutrality. Thus in March and April alone, over a million tons of British shipping seem to have been sunk. Whereas in the first thirty months of the war Britain lost some $3,000,000$ tons by this warfare (never then wholly ' unrestricted '), - and in the next two months (Dec. I9I6-Jan. I9I7) slightly over 500,000 tons-the first eight months of the new ' ruthless' campaign, though far from realizing German hopes, were more costly than all the earlier time.

On the other hand, the definite action of the United States against Germany on April 6 was quickly followed by similar war-declarations from other American republics, and from states in other continents-Cuba and Panama on April 7, Greece on July 22, Siam on July 22, Liberia on August 4, China on August I4, Brazil on October 26. Before the Bolshevik current finally swept Russia out of the Entente, almost the whole world might have seemed arrayed against Germany and her three allies.

Powerful squadrons of American war-ships began to arrive in the Eastern Atlantic as early as May, I9I7 : morally and materially their help, and the counsel of their leaders, was invaluable. And, while large increases were planned for the American navy and mercantile marine, enormous preparations were also made by the United States for land warfare. If necessary, the great Republic of the New World declared her readiness to raise levies of ten millions of men.

The closing events of the year were among the most 
remarkable. Russia-now Bolshevik in its central government-made an end of its participation in the war. The Eastern battle-front began to disappear. Arrangements were commenced for an 'immediate democratic peace,' while internal measures of a sweepingly communistic character were adopted. The abolition of landed property was proclaimed : likewise the establishment of the supreme authority of the Soviets or Workers' Councils.

With the Central Powers the Soviet leaders-UlyanovLenin, Trotsky, and the rest-at once opened 'peaceconversations,' and on December I5, I9I7, the combatants signed at Brest Litovsk an armistice, which in the following March became the famous Treaty of Brest.

But again German statesmanship committed fundamental errors. The prolongation of the war and the whole course of events in I9I7 had gradually brought about not only a violent revulsion from war-feeling in Russia, but a considerable war-weariness in some other countries, such as Italy and Britain.

At the close of I9I7 British Labour began to press very strenuously for a more moderate, as well as a clearer, statement of war-aims and peace-conditions; this demand found an increasing and sometimes surprising response from other quarters; and in answer the British Prime Minister made a statement which seemed to offer, at this eleventh hour, no small hope of accommodation, even at the price of abandonment of all the more rigorous and punitive terms of the Entente.

But for an agreement, as for a quarrel, two parties are necessary. And the German government, in- 


\section{I 2 NINETEENTH CENTURY EUROPE}

toxicated by success, and blind to the immense dangers still threatening and daily increasing, took no advantage of this last opportunity. On the contrary, by its treatment of Russia, it seemed indeed to "prove to other countries what they might expect.'

By the Treaty of Brest-Litovsk the Bolsheviks were compelled to relinquish and detach from 'the former Russian Empire' a vast belt of territory (March 3, I9I8). Not only did that empire now part with many lands of alien race, such as Finland, Livonia, Courland, Lithuania, the Russian Poland or Congress-Poland of I8I5, and a certain part of her other western gains, but she surrendered to a newly-created Ukraine state, 'delivered' and controlled by German armies, all the Little Russian lands of the South, and extensive regions long ago colonized by the Great Russians of Moscovy. With this Ukrainia, fully 400,000 square miles in area, or twice the size of France, went some of the most ancient, some of the most famous, and some of the most vital centres of the Russian peopleKiev, Kharkov, Poltava, Kherson, Rostov-on-the-Don, the Northern Crimea, the whole sea-board of the Azov, both sides of the Cimmerian Bosphorus or Straits of Kerch, even Odessa and Novo-Rossiisk. Lastly, on the side of Asia, most of Russian Armenia-Kars, Batum, Erivan-was ceded to Turkey.

Sixty-five millions of Russian subjects were thus detached from Russian allegiance. And the bulk (perhaps 70 per cent.) of the coal and iron hitherto known and worked in the Empire, or at least in European Russia, was hereby surrendered.

Such a treaty (whose effect was little relieved by the comparative mildness of the Rumanian Convention a 
little later) ${ }^{1}$ effectually crippled all pacifist movements, and produced a definite hardening in the countries of the Entente, and in America. The war, men said, must be resumed more intensely than ever, and carried to a finish.

On the other side, at German Headquarters, the extremest views prevailed. Now that the East European war was over, and the Russian front freed of danger, like the Rumanian, the Western struggle was to be ended by no compromise, by no ' soft peace,' but by absolute and crushing military victory. Yet, in order to keep down the vast Russian areas she had occupied, Germany was obliged to retain fully a million soldiers in what had been Russian lands of the west and south. No conception of the possible value of Russian friendship and alliance, so prized by some older German statesmen, such as the discredited and antiquated Bismarck, seems to have occurred to William II. and his circle, madcap heirs of the Bismarckian empire and policy.

So on March 2I, I9I8, a new and tremendous offensive, in the Verdun manner, but of still larger dimensions and fiercer intensity, was opened by the Germans along the middle sectors of the French front-towards Bapaume and Peronne, St. Quentin and Noyon. For a time it met with staggering success. The British centre was driven in, and forced back behind the

${ }^{1}$ By this Treaty of Bucharest Rumania ceded her territories south of Danube (Dobruja, etc.) to Germany and her allies jointly, and ceded to Austria-Hungary strips of land on the Rumanian side of the Carpathian passes, and especially near Orsova and the Iron Gates. By the same treaty the Central Powers also gained a powerful hold upor the economic resources of Rumania. 


\section{I4 NINETEENTH CENTURY EUROPE}

Somme; the British left fell back towards, and at last behind, Arras; the French lost much valuable ground, up to Montdidier; Amiens was closely approached, and in evident danger. All the gains of I9I6 and I9I7, on this side, were torn away (March 2I-28, etc.).

But with the consciousness of 'unbounded' American aid on its way, or in preparation, and of considerable American aid now rapidly arriving (83,000 trained men came over in March), the AngloFrench resistance stood fast; both governments, like that of Washington, hurried every available man to the front; Marshal Foch, a brilliant and effective commander, from the September days of I9I4, was made Commander-in-Chief of all the Entente armies on the West; unity of command against Germany was achieved; Amiens was held.

In April, none the less, a fresh German onslaught further to the north wrested considerable pieces of ground from British, French, and Portuguese. Yet the loss of territory here was far slighter than in the terrible days of March; Ypres, though under closer and severer pressure, still held out.

But worse was to come. After a long pause, during which American munitions and men poured into Europe, the Germans attacked afresh in some of the southmost sections of the line, between Soissons and Rheims, in the closing days of May (27-3I). Here again success, however temporary, was rapid and astonishing. At the beginning of June, after four years, the invaders were again on the Marne, and Paris, perhaps, again in peril.

A fourth offensive, to the north-east of Paris, in mid-June, resulted in a limited German advance at 


\section{THE WORLD-WAR, I9I4-I 8}

the expense of the French centre, and a further apparent increase of peril to the French capital (June 9, etc.).

But the turn of the tide was approaching. Although the French government (which had momentarily withdrawn to Bordeaux in the critical fifth week of the war) was again discussing, after nearly 200 weeks, a possible departure at any moment to some provincial city-and although anxiety was now perhaps more freely expressed than ever before in the Entente pressGermany had reached the limit of her successes. Her losses in man-power had been great: her expenditure in every way enormous. The exhaustion of her people, hard pressed by food shortage, at least since the opening of I9I6, and weakened by the immense slaughter and the enormous military efforts of four years, was only partially concealed by the exultation of extraordinary fortune and the confident assumption of ultimate and complete victory. Any prolonged spell of reverses would probably have a terrible effect.

The exhaustion and the losses, however, of all the older combatants were great-in some cases stupendous -and the effect of American succour was in proportion. By the middle of July the United States had sent far more than a million soldiers to France-before the armistice these numbers had risen to two millions; had the war continued into I9I9, as perhaps most even of the well-informed expected, Europe might well have been visited by armies from the Western world surpassing those of any other warring power. As to material-long before the 'men from Atlantis' had arrived in any force, the New World had furnished inestimable aid. Without this, it may be confessed, the 


\section{NINETEENTH CENTURY EUROPE}

adequate maintenance of the struggle on the Gallic front would indeed have been difficult, at certain times.

So when, on July I5, another Teutonic onslaught began-this time on both sides of Rheims-Foch was ready to strike back. On July 18 he commenced a counter-attack which proved the beginning of the end. Instead of minute gains, at terrible loss, soon ending in a practical deadlock, the Entente armies now retained a profitable initiative, and maintained a steady and prosperous advance from week to week, from month to month, for the remainder of the war.

Within three days the Germans who had crossed the Marne were forced back north of the river. To the surprise of the world this movement of retreat continued to widen and deepen, and even to accelerate, until before the end of September the Teutonic hosts were again standing on the Hindenburg Lines, having lost nearly all their 'recoveries' of the spring and early summer, and considerable territories which had been theirs since I9I4. German morale was giving way.

On September 26 began what was really the concluding and deciding battle or battle-period of the war. The Hindenburg Lines, already seriously menaced by attacks on the wings, were now violently assaulted in the centre, and broken through, in a fortnight of desperate fighting. And at the same time arrived news of utter disaster in Syria and in Thrace. For some time, defection, demoralization, and something like panic, had begun to declare themselves on a great scale within the German army and the German people. It had been supposed, with reckless optimism, that 
America would never fight; that even if she wished to make war, she could never raise an army; and that if she did raise an army, she could never transport it to Europe. Faced with the ruin of every hope, pursued with daily-increasing evidence of overwhelming force in the field against Germany, German confidence and German resolution now broke down.

By October II the mighty basic system of defences -Siegfried lines, Wotan lines, and the rest-popularly known by the name of the Teuton army-chief, had been pierced; St. Quentin and Cambrai had fallen; Ostend and other vital points were in evident readiness to fall ; the German 'will to war' was vanishing, almost as the Russian had done ; in a short time the invaders' hold on Gallic and Belgic territory would be utterly shaken off.

In the middle of October the whole Flemish coast, right up to Zeebrugge, was abandoned by the Kaiser's troops; likewise Lille and the bulk of the great industrial district of Lille, with Turcoing and Roubaix; likewise the fortress-city of Laon; likewise almost every relic of the French territory in German occupation. The front was again becoming, as it had been in some of the first days of the conflict, a Belgian line. Nor would that long avail. The end of all things was at hand.

Startling news, meanwhile, came from other theatres of war. In Syria, Allenby, strongly reinforced with British troops, and with the help of a small French contingent, broke the Turkish 'Samaritan' front in the middle of September. For the Ottomans, eagerly prosecuting conquests and adventures in the Caucasus, 


\section{NINETEENTH CENTURY EUROPE}

and especially towards Baku and its oilfields, had fatally weakened and neglected their Palestine and Mesopotamian defences.

So all the centre and north of the Holy Land were speedily conquered. Syria proper was then entered; Damascus captured; and Bairut secured by a naval attack (in early October). Soon everything up to Aleppo and the north Syrian section of the Baghdad railway had been overrun by the Entente armies (before the end of the same October).

And, at the same time, on the Salonica front, Franchey d'Esperey, the French leader of the large composite force which here fronted the main Bulgarian army, taking advantage of the diversion of most of the German contingent from this field to France, and still more aided by the rapid progress of discouragement and demoralization within all Bulgarian ranks, civil and military, achieved equal success. With little serious resistance he mastered some of the keys of the Bulgarian defences, though of immense natural strength, in a most rugged and difficult mountain country. Pro-German elements now wholly lost power in Bulgarian politics, and the 'bad boy of the Balkans' offered a practically unconditional surrender at Michaelmas (September 29, rgr8).

On the Italian front also, the war rapidly approached its now inevitable conclusion. A year after Caporetto, the survivors of that disaster, powerfully strengthened from France and Britain, saw their revenge upon their enemies. The Austrians were driven over the Alps, with enormous loss, and the Dual Monarchy, that 
house so long divided against itself, began to be brought to nought. North Slavs, South Slavs, Magyars, and Rumans-the Nationalists of Bohemia and Bosnia, of Moravia and Croatia, of Hungary and Transylvaniawere all, only too clearly, breaking away from the feeble bonds of Hapsburg Unity. The 'Hereditary Empire of Austria' was dissolving into Balkan conditions. That which, 'if not existent, ought to have been invented' (as British diplomacy had long held), was now ceasing to exist.

At the end of October, therefore, both Constantinople and Vienna sued for peace. An armistice to the former was granted on October $3 \mathrm{I}$, to the latter on November 4-to both on terms of complete submission and disarmament, and with the prospect of enormous indemnities and territorial disruption.

And now Germany, left alone without allies, and at last overborne by overwhelming force and the despair of her own people-the ship of state plainly shattering upon the rocks to which an insane steering had driven ber, was herself compelled to ask for terms. And at the same moment-in early November-internal revolution, seriously threatened ever since the fortunes of war changed in July, broke out all over the German Empire. By November 7, mutiny and socialism had become the order of the day at Kiel and throughout a great part of the German navy; on November 8 the Entente terms for suspension of hostilities were communicated to the German peace-delegation; on November 9 Kaiser Wilhelm abdicated, confronted with the universal collapse of the old order; and on November II the commencement of the armistice was 


\section{NINETEENTH CENTURY EUROPE}

officially announced, together with the flight of the German Emperor to Holland. A whirlwind seemed to sweep away all the princes of the Empire at one breath, together with the imperial system and the whole world-position of the Germany which Bismarck and the alte Kurs had built four-square, and which their successors had undermined. 


\section{BIBLIOGRAPHY 1}

\section{PART I}

\section{GENERAL COLLECTIONS OF DOCUMENTS AND OTHER HISTORIC MATERIAL}

Among the chief regular and semi-official publications dealing with recent political events in Europe are the following, which all contain official documents and supply invaluable collections of historical material :-

Annuaire historique universel [from $18 \mathrm{I} 8$ to $\mathrm{I} 86 \mathrm{r}$ ]. Annuaire des deux mondes [from 1850 to 1870 ]. Année politique [from I874].

Annual Register [beginning in the eighteenth century, and continued ever since].

Europäischer Geschichts-Kalendar [ed. Roloff, Schulthess and Delbrück, 'since I860 the most complete of all ']. Still more fundamental is the Staatsarchiv, ed. Ægidi, Klauhold, Worthmann, etc.35 vols., I880 [" the leading collection of the documents common to all Europe'-a Collection of official data for contemporary history, as it describes itself in its sub-title. It has been published since I86I, and was preceded by such collections as the Archives Diplomatiques, I821, and the Neueste Staatsakten, I825.]

See also

LangloIs, С. V., Manuel de Bibliographie historique, I8g6.

1 It would be easy to make a list ten times as long, often containing material hardly less useful, and it is probable that in this selection I have omitted some works that could ill be spared, but my space only permits a few suggestions. Publications of especial importance for practical study in Part III are starred.

N.C.E. 


\section{PART II}

Among General Histories, and works dealing with Nineteenth Century Europe as a whole, the following may be mentioned :

Alison, Sir A., History of Europe, Vols. XI, XII, r853. The Alcan Collection-Bibliothèque d'Histoire contemporaine.

Bulle, C., Geschichte der neuesten Zeit [goes to 1885, in the 4 volumes of the 1886 edition: one of the most exact and critical of all general presentations of nineteenth century history].

$\checkmark$ Cambridge Modern History, Vol. XI, e.g. chaps. xv, xvi, xxi ; Vol. XII, e.g. chaps. i, vi, vii, viii, xii, xiv, $\mathrm{xx}$.

$\checkmark$ DÉBIDour, A., Histoire diplomatique de l'Europe I8I4-1878, 2 Vols., I89I; Hist. dipl. d. l'E. depuis le Congrès de Berlin ..., 4 Vols., I9I6-I7.

DROYSEN, G., Historischer Hand-Atlas, 1886.

Encyclopaedia Britannica [new ed.: many excellent historical articles, especially on biographical side, useful both for politics and culture], IgIO-II.

$\checkmark$ Freeman, Edward A., Historical Geography of Europe, ed. J. B. Bury, I903.

- FyfFe, C. H., History of Modern Europe, 1792-1878 [of great merit], edition of $\mathrm{r} 8 \mathrm{gr}-2$.

$\checkmark$ Gooch, G. P., History and Historians of the Nineteenth Century, I9I3; Annals of Politics and Culture, [both valuable: the former invaluable].

Handwörterbuch der Staatswissenschaften, 7 Vols., I890-95 [for Economic history].

HAWKESWORTH, The Last Century in Europe, I8I4-rgio [painstaking, clear, and honest].

HeLmolt, Weltgeschichte [also E. tr., The World's History, especially Vol. VIII.; particularly useful for German history, I907].

HERBST, Encyclopädie der neueren Geschichte. 
Hertslet, Sir Edward, Map of Europe by Treaty, 4 Vols., I875-I89I.

LAVISSE and RAMBAUd, Histoire générale ...., Vols. IXXII, I898-I904 [in many ways perhaps the best of the recent co-operative universal histories].

Meyers Konversations-Lexikon [various useful articles, as in Encycl. Britannica, but especially on German subjects], I903-10.

Nouvelle Biographie générale [useful, like the Encycl. Britannica, but often unsatisfactory].

OAKEs and Mowatr, Select Treaties and Documents... I8I5-I9I6, I9I6.

The Oncken Series, certain volumes of, devoted to Recent History from I789 [Allgemeine Geschichte in Einzeldarstellungen; see below, Oncken, in Part III.].

- Phillips, W. Alison, Modern Europe in the 'Rivington' Series, Periods of European History [admirable for certain things, e.g. German unity], I90I.

Robertson (C. Grant) and Bartholomew, J. G., Historical Atlas, I789-I9I4 [very serviceable], I9I7.

$\checkmark$ Rose, Holland, Development of the European Nations, I870-I9I4, new edition, I9I6.

SChrader, F., etc., Atlas Historique, I893.

* Seignobos, Charles, Histoire politique de l'Europe contemporaine [I8I4-I900; also E. trans.].

Spruner-Menke [K. Spruner; Th. Menke], Historischer Hand-Atlas, I880 [one of the great works of historic geography].

Staatengeschichte der neuesten Zeit [a valuable series of histories of the different European countries; 'this is the most important collection for domestic history ']. Stern, A., Geschichte Europas... I8I5-I87I, 7 Vols., to I853 [of very high value]; I9I4-I6.

Srokvis, A. M. H. J., Manuel de l'Histoire ... de tous les Etats $d u$ globe, 3 Vols. [of the highest usefulness], 1888-93. 


\section{PART III}

Among works dealing with separate countries, subjects, and periods may be mentioned :

*Allgemeine deutsche Biographie, I875-... [a treasurehouse of historical material, the 'Dictionary of German National Biography'].

$\checkmark$ BEAZLEY, Forbes and Birkett, Russia from the Varangians to the Bolsheviks, I9I8 [Nineteenth Century by G. A. Birkett].

Benedetti, Count, Essais diplomatiques, I895.

"Beust, Count, Aus drei Viertel-Jahrhunderten, 2 Vols., I887 [also E. trans., Memoirs of ... Beust].

*Branchi, Storia documentata della Diplomazia Europea in Italia, 8 Vols., I8I5-72.

*Bismarck, Prince, Gedanken u. Evinnerungen, ed. $\mathrm{H}$. Kohl, 2 Vols., 1898 [also E. trans., Reflections and Reminiscences, 2 Vols., I899]; also, Anhang zu G.E.-Kaiser W. und B.-Aus B.'s Briefen, 2 Vols., I90I ; also, a supplementary Vol. of G.E., I92I [E. trans., New Chapters of B.'s Autobiography]; Bismarcks Briefe an s. Braut...., Igoo; [see also Hahn, William I, $\checkmark$ Headlam, Kohl, Lowe, Marcks, Egelhaaf, etc.].

*BRIght, John, Letters, ed. Leech, 2 Vols.

Bunsen, BARon, A Memoir, 2 Vols., I868.

Busch, M., Unser Reichskanzler, 2 Vols., I884 [also E. trans.] ; Bismarck ... Secret ... History, 3 Vols., I898 [an E. trans., with additions-perhaps not always trustworthy - of the Busch Tagebuchblätter of 1878$]$.

$\checkmark$ Cavour, Count, Life of, by the Countess Cesaresco. I904.

$\checkmark$ Cobden, Life, ed. Lord Morley, 2 Vols., I88r.

$\checkmark$ COXE, ARChD., History of the House of Austria [in its last continuation, to I848, edition of I895].

$\checkmark$ Cunningham, Ven. Will., English Industry and Commerce, 3 Vols., 1892 edition. 
*Dawson, Will. HaRbutt, The German Empire, I867-I9I4, 2 Vols., I9I8 [excellent; citations from sources very valuable].

*Delord, TAXile, Histoire du Second Empire, 6 Vols., 1868-75 [one of the best works on the subject].

* Dictionary of National Biography [as valuable for British history, as the All. deutsche Biographie for German].

Dilke, Rt. Hon Sir Chas., Present Position of European Politics, I887.

$\checkmark{ }^{*}$ Disraeli, Benjamin, Earl of Beaconsfield, Life and Letters [ed. Monypeny and Buckle], 6 Vols., I9Io-20.

( Douglas, R. K., and LongFord, J. H., Europe and Far East, I506-I9I2, I9I3.

*DuRham, Edith, Twenty Years of Balkan Tangle, I920 [full of original contribution to recent Balkan history].

EgelHAaF, G., Bismarck... Leben und...Werk, IgII ; Geschichte der neuesten Zeit, 6th edition, I9I6 [both brief and masterly].

FigUIER, Les merveilles d. l. Science.

FORSTER, Life of Deak.

Funk, Kirchongeschichte, 2 Vols.

GARDINER, S. R., Students' History of England [concluding chapters to I885], new edition, 3rd Vol., I894.

* Gladstone, Right. Hon. W. E., Life and Letters [ed. Lord Morley], 3 Vols., Igo3.

Gontaut-Biron, A. A. E. DE, ... Ambassade en Allemagne [I872-77], Ed. A. Dreux, 2 Vols., I906-7.

* *Gorce, P. D. LA, Histoire de la Second République française, 2 Vols., 1887; Histoire du Second Empire, I894, etc.

* Granville, Earl, Life [and Letters], ed. Lord Fitzmaurice, 2 Vols., I905.

Greville, C. C. F., Memoirs, 8 Vols. [full of official and other gossip, sometimes important, for the period I8I7-I860], I875-87.

$\checkmark$ GREen, JoHn RICHARD, Short History of the English People;-Epilogue I8I5-I9I4 by Alice Stopford Green [an admirable survey].

N.C.E. 
Guizor, F. P. G., Mémoires pour servir a l'histoire de mon temps, I858-67.

*Hahn, L., Fürst Bismarck, 5 Vols., 1879-I89r [a standard collection of all Bismarck's speeches and declarations].

*Hanotaux, Gabriel, Histoire de la France contemporaine, I87I-, 4 Vols published, I903-8.

*Hansard, Debates in Parliament [British].

*Hardenberg, Prince, Denkwürdigkeiten, ed. Ranke, 5 Vols., I877.

* Headlam, J. W. [Headlam-Morley], Bismarck and the Foundation of the German Empire [Heroes of Nations Series], I899.

$\checkmark$ *Hohenlohe-Schillingsfürst, Prince, Denkwïrdigkeiten, 2 Vols., I906 [also E. trans., H. Memoirs, 2 Vols., I906].

$\checkmark$ Iddesleigh, Lord (Stafford Northcote), Life, ed. Lang, 2 Vols., I8go.

Johnston, Sir H. H., History of the Colonization of Africa, 4th edition, Igr3.

Keltie, Sir J. Scott, Partition of Africa, 2nd edition, I895

[a standard work of the 'Nineties].

*KING, Bolton, History of Italian Unity, 2 Vols., I899.

*Klüber, J. L., Akten d. Wiener Kongresses, 8 Vols. I 8 I5-1835.

*Konl, H., Politischen Reden... Bismarcks, I4 Vols., I892-I904.

*KolB, Handbuch der Vergleichenden Statistik, 8th edition, I879 [E. trans., Condition of Nations], ' the most reliable work of this kind.'

KURTZ, Lehrbuch der Kirchengeschichte, 2 Vols., I885 (9th edition).

LaMPREcht, KarL, Deutsche Geschichte, especially supplementary Vol., Zur jüngsten... Vergangenheit, 2 parts, I902-3.

1 LEger, Louis, Histoire de l'Autriche-Hongrie, 4th edition, I895 [' one of the best . . . of the Duruy Collection '].

$\checkmark$ LeRoy-Beaulieu, A., L'Empire des Tsars, 3 Vols., I $88 \mathrm{I}-89$. 
Lowe, Charles, Life of Prince Bismarck, 2 Vols. [journalistic, but with much valuable citation from original sources-to I885 only].

$\checkmark$ *Lowell, Lawrence, Governments and Parties in Continental Europe, 2 Vols., I897 [excellent American survey and analysis].

*Lyons, Lord, Life and Letter's, ed. Lord Newton, 2 Vols., I9I3.

McCARThy, Justrn, History of Our Oren Times, 5 Vols., I880-97.

* Manteuffel, O. v. [Prime Minister of Prussia, I850, etc.], Denkwürdigkeiten, 3 Vols., I902; Unveröffentliche Dokumente, 3 Vols., I902; both ed. $\mathrm{H}$. v. Poschinger.

*MARCKS, ERICH, Bismarck, ein Lebensbild, IgI5; Bismarck, eine Biographie, Vol. I, I9I5 [only to I848 as yet, but of highest merit].

MaRTEns, F. DE, Recueil des traités . . de la Russie avec les puissances étrangères, I2 Vols., I874-92.

* Martin, Sir Theodore, Life of the Prince Consort, 5 Vols., I880 [important; much original material].

$\checkmark$ Matter, Paul, Bismarck et son temps, 3 Vols., I905-8 [best French study of Bismarck].

*Metternich, Prince, Nachgelassene Papiere, 8 Vols., I88o-84 [E. trans., in 5 Vols.].

MilleR, W., Ottoman Empire, I8oI-I9I3, I9I3.

MoltKe, Field-Marshal, Count, History of the FrancoGerman War, I878 [a brief survey by the 'masterspirit'].

Morfill, W. R., Russia from Peter the Great..., Igo2.

* Morier, Sir Robert, Memoirs, 2 Vols., igit [always interesting and vigorous, sometimes violent and illjudged, often suggestive, and occasionally ' at the centre of the situation '].

ONCKen, Oncken Series, various contributions, e.g. Zeitalter der Restauration und Revolution, 2 Vols., I887; Zeitalter des Kaisers Wilhelms I, 2 Vols., I892 edition.

* Pulmerston, Lord, Life and Letters, ed. Dalling and Ashley, 5 Vols. ; Life, by Lytton Bulwer, 2 Vols., I87I. 
*Peel, Rt. Hon. Sir Robert, Life and Letters, ed. Parker, 2 Vols., 1899.

PRICE, M. PhILlIPS, Diplomatic History of the War, IgI4.

$\checkmark$ Prothero, Sir George W., German... policy before the War, IgI5 [suggestive; but concentrates almost entirely on Near East].

$\checkmark$ Rambaud, Alfred, Histoire de la Russie, new ed., I893 [the best short history of Russia in French or English; also E. trans., Hist. of $R ., 2$ Vols.].

*Robertson, C. Grant, Bismarck, IgI8 [brilliant and suggestive, especially for the last years, I878-90].

$\checkmark$ Robertson and Marriott, Evolution of Prussia, I9I7 [unequal ; better for earlier periods than for I8I5-I9I4]. *Roon, Count, Field Marshal, Denkwürdigkeiten, 3 Vols., I905 (5th ed.).

Rumania-A us dem Leben . . Karls v. Rumänien, 4 Vols., I894-I900 [also E. trans., Reminiscences of the King of Rumania-I Vol.--only deals with part of original text].

RUSSELl, LoRd John [EARL], Recollections, I875. See also Spencer Walpole.

$\checkmark$ *SeEley, Sir John, Life and Times of Stein, 3 Vols., I88o.

SKRINe, F. H., Expansion of Russia, I8I5-Igoo, I904. *Sorel, A., Histoire diplomatique d. l. Guerre francoallemande, 1875 ; Le Traité ... de I8I5, 1873.

*Springer, A., Geschichte Oesterreichs, 2 Vols., I865 [in the Series Staatengeschichte d. Neu. Zeit].

'StEPNIAK' [KRAfChEVSKY], La Russie Souterraine, I885.

Stillman, W. J., and Trevelyan, G. M., Union of Italy, I8I5-I898, I909.

StOckmar, Baron Christian Fr., Denkwürdigkeiten, 1872. *Sybel, H. v., Die Begründung d. deutschen Reiches, 7 Vols., I893-4, 4th edition [very important; semi-official; also American trans. Founding of the German Empire].

TIKHomirov, Russie politique et sociale, I886.

TODD, A., Parliamentary Government in England, 2 Vols., I887-9 (2nd edition). 
$\checkmark$ *TREITschke, H. V., Deutsche Geschichte in XIX Jahrhundert, 5 Vols., I879-I894 [of the first importance, in spite of violent partisanship; sometimes semi-official ; also E. trans., Hist. of Germany in the XIX. Century, which leaves much to be desired].

$\checkmark *$ Victoria, Queen, Letters [to I86r], 3 Vols., I903 [one of the chief collections, even mure valuable for international than for domestic history].

Vienne, Acte d. Congrès d. [for London Foreign Office].

'Vladimir,' Russia on the Pacific . .., I899.

*Waitz and Dahlmann or 'Dahlmann-Wartz,' Quellenkunde der deutschen Geschichte, I9I2 [8th edition, revised. 'the best of all the national historical bibliographies '].

\ IVAllace, Sir D. Mackenzie, Russia, 2 Vols., I879.

* Walpole, Sir Spencer, History of England since I8I5, 6 Vols., 1878-90 [very complete and good]; Life of Lord John [Earl] Russell, 2 Vols., I8gr.

6 *WARd, Sir Adolphus W., Germany, I8I5-I890, 3 Vols., completed I9I7-I8 [the best history of Nineteenth Century Germany by any English writer].

Webster, C. K., Congress of Vienna, IgIg; British Diplomacy, I8r3-I5, I92I.

Iirliam I, Emperor and King, Correspondence with Bismarck, 2 Vols. E. trans., IgO3 [contains much other matter].

Windischgrätz, Prince, Memoirs of ... I848-49, I85I. 


\section{INDEX}

A

Aachen, Aix-la-Chapelle, 38.

Abdul Hamid, Sultan of Turkey, $257,287$.

Abdurrahman Khan, 238.

Aberdeen Government, 82.

Abyssinia, Italy and, 274.

Adelaide, city of, 235.

Adowa, battle of, 274 .

Adrianople, Agreement, 217-18 ;

- city of, 259.

Afghan(s), Afghanistan, 96, 237-8, 239, 266.

Africa, Tropical, 97. French in, 268: German East Africa, 293: German South West A., 294; South A., 236, 239.

Agadir crisis, 258.

Aisne, battle of the, 285, 309 .

Albania, Albanian(s), Arnaut(s), 259, 260, 293.

Albert, of Saxe-Coburg Gotha, British Prince Consort, 256.

Alexander I., Tsar of Russia, I4, 21-23, 50-5I, 122.

Alexander II., Tsar of Russia, the 'Liberator,' 96 ; his desire for Prussian alliance, 120 ; his freeing of the Serfs, 122 ; A. and Poland, 124, 196, 207, 214 , $221,226,229$.

Alexander III., Tsar of Russia, the 'Pacificator,' 89-97, 223-4, 229, 230; his trust in Bismarck, 23I, 271-2.

Alexander, King of Serbia, 257. Allenby, Field Marshal, 309, 317 . Alliance, the Holy, 50-1, 206.
Alliance, the Triple. See Tripls Alliance.

Alma, battle of the, 85 .

Alps, 103.

Alsace, Alsatian(s), 183, 187, 300.

Alsen, Isle of, 138.

Altona, 135, 142.

America, United States of, 17, 234; their attitude to Germany before war, 257 ; tension over Lusitania, 294; President and German war aims, 304 ; entry into war, 305-320, passim; effect of American help, 315.

American Civil War, I69.

American War of Independence, 234.

Amiens, 309, 312, 314.

Amur, river, frontier, 89 .

Andrassy, Count, Hungarian statesman, 221.

Anti-semitism, 269.

Antwerp, 57-8, 282, 285.

Arabi Pasha, 26r.

Argonne, forest of, 285 .

Argesu, battle of the, 30 .

Armenia, Armenian, 223, 238,

272.

Arnold, Thomas, 7 r.

Arnold, Matthew, 72, 192, 199.

Arras, town of, 298, 307, 314.

Aschaffenburg, 154 .

Asia, Central, 96 ;

_- Western, 293.

Asquith, H. H., British premier, 303.

Augustowo, 289. 
Ausgleich (Austro-Hungarian), $167-8$.

Australia, 40, 236-8, 243.

Austria, Austrian(s), Dual Monarchy of Austria-Hungary, II, 12, 16, 23-5, 36, 45, 49, 52, 66-7I, 80-8r, 83-5, 90, 9I, 93 , 95,227 ; its Alliance with Prussia, 99, 132; with the new German Empire, 226-8; Franco-Italian War with, I02, 104-5, 107; A. and Prussia at the Frankfurt Diet, Ch. vi., 127-131; A. and Hungary, 173, 277 ; A.'s reparation note to Serbia, 1914, 279; A. and War of $1914,280-370$ passim; blockade of, 288 ; break up of, 319.

Avellan, Admiral, 248.

Azov, Sea of, 312.

\section{B}

Baghdad, railway, 225 ; road to, 260; British capture of, 294, $307,309$.

Balaclava, battle of, 85,86 .

Balkan League and War of 1912-13, 238, 259-61, 274-7.

Balkan States, 52, 213, 272, 319.

Balkan Christians, 223, 259 ;

- attitude to Russia, 91-3.

Baltic, Baltic provinces, 272, 308.

Baluchistan, 238.

Bapaume, 307, 313.

Barrua, 263.

Basra, 294.

Batum, 220, 312.

Baudry, 200.

Baur, F. C., theologian, 72.

Bautzen, battle of, 23, 24.

Bavaria, Bavarian(s), 27-8, 3 I-2, $34,147,183$.

Bazaine, Marshal, 184-5, 188. Beaconsfield. See Disraeli. Beatty, Admiral, 302.
Beaumont, 186.

Belfort, 186.

Belgrad(e), 292, and see Serbia.

Belgium, Belgian(s), 3I-2, 42-3, $46,56-9,144,317 ; B$. and War of $\mathrm{I}^{\mathrm{I}} \mathrm{I}, 28 \mathrm{I}-320$ passim.

Benedek, Ludwig, Austrian General, 149, 152, I 54.

Benedetti, Count, French diplomatist, $158,162,178-179$.

Berlin, 18, 27, 66, I19; Conference for African settlement, 1885,241 ; Congress and Settlement of, 1878, $214,221-2,234$, 261.

Bernstorff, Count, German Ambassador to U.S.A., 304-5.

Besika Bay, 83.

Bessemer, 97.

Bessarabia, 36, 93, 96.

Bethmann-Hollweg, German Chancellor, 295, 303.

Beust, Count, Austrian Chan. cellor, etc., 127, 168, 173, 204 , 205.

Biarritz, 'Conversations' at, 143. Bieberstein, Baron Marschall. German ambassador, 79.

Bismarck, Otto E. L., Prince, Prime Minister of Prussia, German Chancellor, 66, 78, 81-96, 99, 100-1, 106, I13 (B. and Italy), II4-248 passim, and especially I I 5 (P.premier), I I 6 . 19, I $21,128,139,202.4$ (character and aims), 1 1 8.19, 143.5 (B. and Austria), 155, 162, I 7 1-2, $179.8 \mathrm{r}$, etc. (B. and France), $175,219,229,313$, etc. (B. and Russia), 219,225 , etc. (B. and Turkey), 240-5, etc. (B. and Britain), 240-r, etc. (B. and German colonies), 233 , etc. (B. and Triple Alliance), I14, I18.19, I2I, 164, I 92 (B. and internal politics), 246.7 (retirement). 
Britain, British, 17, 22, 24, 25 , $39,40,49,105,218$, etc.; B. Reform and Free Trade, 50, 55-6, 60-61 ; B. and Russia, 77 , 95,$227 ;$ B. and France, 126, 131, 132, 266: B. antagonism to Germany $256-265$; B. understanding with Germany, 249-25I ; B. colonial development in South Africa, 234-236; $B$. in East Africa, $263 ; B$. North America Act, 198; B. and War of $1914,28 \mathrm{I}-320$ passim.

Brünn, I 54 .

Brussels, 57, 282.

Bruges, 286, 293.

Bryce, Lord, historian, diplomatist, etc., 199.

Bucarest, 301-4; Peace of, 260.

Bukhara, Khanate of, I69.

Bukovina, province of, 298.

Bülow, Prince von, 257.

Bulgaria, Bulgarian(s), 217,238 , 259,276 ; B. Atrocities, $213-$ 218,$247 ; \mathrm{B}$. in war, 1915-18, 292-301.

Bundesrath, 92, 166.

Bunsen, Wilhelm, scientist, 112. Burton, Richard, explorer, 97.

Calcutta, 244.

Cambrai, 283, 309, 317.

Cameroons, 243, 251, 294.

Canada, 40, 195, 234-5.

'Canossa,' 2 ro.

Cape of Good Hope, Cape Colony, 40, 236, 237.

' Cape to Cairo' Railway, 263.

Caporetto, battle of, 308 .

Caprivi, Count, 248.

Carducci, 199.

Carlyle, Thomas, 146, 167, 196.

Carpathian Mts., 289, 300-I

Carroll, 'Lewis,' r99.

Carso, uplands, 308.
Caspian Sea, 238-9.

Castlereagh, Lord, British states. man, $5 \mathrm{I}$.

Catherine II., Russian Empress, 74, 93, 95.

' Catholic Revival,' 'Emancipation,' etc., 47, 55-6.

Caucasus, 54, 317 .

Cavour, Count, Italian statesman, 78, I00-III passim, I68. Chad, Lake, 251, 263.

Chalons, 184-6, 286.

Chamberlain, Joseph, British statesman, 255, 262.

Champagne, 30,184 .

Charles Antony of Hohenzollern, Prince, 176, 177.

Charles V., Emperor, I89.

Charles X., King of the French, 51-56.

Charleroi, 283.

Chemin des Dames, 285.

Chernaiev, General, 248.

Chernaya, battle of the, 90 .

China, 96, 264.

Chlum, village of, 152.

Chopin, 71 .

Christian IX., King of Denmark, Clarendon, Earl of, British statesman, 77, 92, 138 .

Clotilda, Princess, I03.

Clyde, Lord, $\mathbf{I}_{48} 8$.

Cobden, Richard, 139.

Coblenz, Koblenz, 38.

Cologne, Köln, 38 .

Compiègne, 286.

'Commune,' the (1871), 208.

Comte, Auguste, philosopher, $7 \mathbf{I}$.

Concert of Europe, 34, 82.

Concordat (between Church and France), 270.

Congo, 25I, 258; Belgian C., 282.

Constantine, King of the Hel-

lenes, 293.

[289, 306 .

Constantinople, 75, 79, 80, 83 .

Constanza, port of, 301 .

Cook, Captain, 238. 
Copenhagen, 137, 138.

Coup d'Etat of 1851,64 .

Courland, Kurland, 312.

Cracow, Krakow, $4 \mathrm{I}$.

Crimea, Crimean War, 73-97, and esp. 86-90, 96, I01, 312 ;

Crispi, Francesco, Prime Minister of Italy, 108, 203, 233, 275.

Croatia, 168, 260, 319.

Crookes, Will., scientist, 201.

Custozza, battle of, 68, I5I.

Cuvier, naturalist, $7 \mathrm{I}$.

Cyprus, Island of, 222, 232.

Czechs, Chekhs (Bohemian and Moravian Slavs), 277.

Czernowitz, 298.

\section{D}

Dago, Island of, 308.

Dahn, J. S. F., historian, II2.

Dalmatia, 260.

Dante, Alighieri, I93.

Dannevirke, 137 .

Danube, 8o, 83-4, 214-16; D. Principalities. See Rumania.

Dardanelles, 289, 292-3.

Darwin, Charles, II2, 201.

Danzig, 23.

Deak, Francis, Magyar statesman, 168.

Delbrück, 200.

Delcassé, French statesman, 269.

Dennewitz, battle of, 27 .

Dennis, scholar, 72.

Denmark, Danes, Danish, 42 ; D.

War of $1864,129,132-141,160$.

Derby, Earl of, 105, 195.

Dewey, Admiral, 257.

Dickens, Charles, 75.

Diedrichs, Admiral, 257.

'Dingan's Day,' 237.

Disraeli, B., Lord Beaconsfield, British premier, I30, I 36, I39, 195, 200, 2I3, 217-2I, 236-8, 240.

Dobruja, 3or.

Dodecanese, Agaean Isla $2 d s, 2 ; 6$.
Döllinger, J. J. I., historian and theologian, 200, 212.

Dorpat University, 272.

Dostoevsky, Russian novelist, 199.

Dresden, 12, 23, 26-28, 150.

Drei-Kaiser Bund, 205, 226, 274.

'Dreyfus case,' 269-70.

Dual Monarchy (see Austria). Dual Control (in the Old German Bund), 131 .

Dual Alliance of $1879,228,229$; of $1891-3,248-9,253$.

Dubno, 'lines of,' 298.

Dufferin, Marquis of, 97 .

Dunajec, battle of the, 290.

Dunkirk, 296.

Durham, Earl of, governor of Canada, 195.

Dvina, river, 308.

Dvinsk, 292.

Dyebich, Prince, Marshal, 53.

E

Edward VII., British Sovereign, $256,265,274,275$.

Egypt, Egyptian(s), 53 ; Turkish threat to, 287 ; British offen. sive in, 309 ; occupation of, 239, 244, 245, 261, 265.

Elba, Island of, $3 \mathrm{I}$.

Elbe, river, 18, 23, 27.

'Elbe Duchies,' 143, I44, 147.

Elector, the 'Great,' of Branden. burg, 242.

Eliot, George, 112.

Ems, I 78 ; E. telegram, I80-I. Entente, Anglo-French, 265 ;

- Triple, 274, 278.

Erckmann-Chatrian, II2.

Erivan, 'Erivanski,' 54.

'Erythraea' (Italian colony'). 274.

Erzrum, Erzerum, 54, 216.

Eugenie, French Empress, 184.

Eupatoria, 85.

Evolution, I I2, 
F

Falkland Isles, battle, 288.

Falkenhayn, General, 300.

Faraday, Michael, 71 .

Fashoda, 254, 264, 269.

Federation of Germany in 1814 -

15, etc. (the Old Bund), 45-7.

Federation of North Germany

(New Bund of 1866), 160-7, etc.

Ferrara, 106.

Ferry, Jules, French statesman, 267-8.

Fiji, 241 .

Finland, Finns, 35-6, 91, 272, 312.

Fitzgerald, Edward, poet, I I 2 .

Flanders, Flemings, Flemish, $285,286,309,317$.

Fleury, 296.

Florence, I 73.

Foch, Marshal, 314, 316.

France, French, II-33 passim, $38,4 \mathrm{I}-4,5 \mathrm{I}-2,56,5^{8-9}, 6 \mathrm{I}-5$, 91-3; Franco-Italian struggle, I13 Franco-Italian Alliance, hopes of, 174 ; Franco-Aus. trian Alliance, hopes of, I 75 ; French feeling against Britain after 1860, 126; Second Em. pire in F., 187; Third Republic in F., 207, 23I, etc. ; FrancoRussian friendship and alliance, 249; French loan to Russia, 27I-2 ; French Colo. nies, 251, 266, 270 I France and the Church, 267 , etc. ; Franco-German War, I69-70, I76-194 passim, 240; F. and the War of 1914, 183, 281-320 passim, esp. 285, 288, 298, $300,307,309,314-5$.

Francis Joseph, Austrian Emperor, King of Hungary, 68$70,107,152,154,168,214$, 221.

Franz Ferdinand, Archduke of Austria, murder of, 279.
Frankfurt, Diet of ("Federal Diet '), 46, 67, I I 7, I I 8 : (Danish Q.) 1 35, 147 ; Congress of 1863 at, $128-9$; free city of, I 59 ; Peace of, 202, 205-9.

Frederick William III., King of Prussia, 12, 19-23.

Frederick William IV., King of Prussia, 66-7, 78, 98.

Frederick Charles of Prussia, the ' Red Prince,' I 5I, I 52, 183.

Frederick the Great (F. II.) of Prussia, 246.

Frederick VII., King of Denmark, 134 .

Frederick, Crown Prince of

Prussia, afterwards German Emperor, 99, I 50.

Freeman, Edward, British historian, 196.

Friuli, 309.

G

Galicia, 290-I, 298-9; the War of r914-1 8 in, 284, 308.

Gallipoli. See Dardanelles.

Galton, 201. [267.

Gambetta, Léon, 186, 188, 262, Gastein, Convention of, 140, 147. Genoa, 43.

Geok Tepe, 239.

Georgia, 36, 91.

Germany, German(s), 9-10, 36, 45-7, 66-70, 106, 257-8; Ger. man Confederation (the Bund) of $1814-66,36,45-7,134,158$; G. unity, 98, 99, I I 4-1 32 pas. sim, 158, 160, 166, 1 72, 181-3 ; Princes of, I I 4 ; South G., I60, 175, I $8 I$; $G$. nationalism in Schleswig, 133; New G. Empire, I89, etc. : G. colonial policy and ventures in Africa, 24I-5, 25I, 274; G. enterprises in Far Fast, 254: Navy, 240, 302 ; Franco-German War, 176-194 passim; G, and War 
or I9I4-I8, 28I-320 passim.; errors of statesmanship in I9I4-18, 3II ; effects of war on, 315 ; Revolution in, 319.

Gervais, Admiral, 248.

Ghent, 286.

Gibraltar, 245.

Gichin, I5I.

Giesebrecht, historian, 97.

Gladstone, Will. E., British Premier, 196, 221, 238-9, 240-4; Gladstone Government and Irish Home Rule, 243-4.

Gneisenau, Marshal, 27,31-2, 240.

' Gold Coast ' of Africa, 263.

Gorchakov, Prince, Russian statesman, 126, $213,228$.

'Gothenburg System,' 199.

Gramont, Duc de, I77, I78-9, 181, 187.

Grant, explorer, 112.

Granville, Earl, I78, I 82.

Gravelotte, battle of, 185 .

Greece, Greek(s), Hellenes, 49, $53-4,223,224,245$.

Grévy, Jules, President of the French Republic, 267.

Grey, Sir Edw., afterwards Vis. count, British statesman, 266.

Grosbeeren, battle of, 27 .

Grouchy, Marshal, 32.

Gurko, General, 216.

\section{$\mathrm{H}$}

Haeckel, Ernst, scientist, 199.

Hainault, 283.

Ham, 307.

Hamadan, 265.

Hamburg, 288.

Hammond, Mr., of British Foreign Office, 178.

Hanotaux, Gabriel, French statesman and historian, 269. Hanover, Kingdom of, 38, 47 , I 47, 159.

Hapsburg. See Austria.
Hardenberg, Prince, Prussian statesman, 19-23.

Hare, John, actor, 199.

Hatzfeldt, Prince, 19-20.

Haussa states, 263.

Haussmann, Baron, 97.

Hegel, philosopher, 7 I.

Heligoland, 39, 42 ; German acquisition of, $245,263,288$.

Helmholtz, scientist, 97.

Henry I., ' the Fowler,' Igo.

Herzegovina, 220, 223.

Hindenburg, Marshal, 284, 286, 289, 305: 'H. Lines,' 307, $309,316$.

Hohenzollerns, 176.7 ; 'H. Can. didature for throne of Spain,' I79.

[I 7 I.

Holland, 40, 42-3, 56-9; King of, Holstein, Duchy of, 47, 132-3, I4I; Estates of, 147.

Holy Roman Empire, I89.

Homburg, Hesse-, I 59.

Home Rule, Irish, 26I.

Hong Kong, 264.

Hood, Admiral, 302-3.

Hugo, Victor, novelist, poet, politician, etc., 7 I.

Humbert, King of Italy, 275.

Hungary, Hungarian(s), 66, 68$70,77-8,289$; Kingdom of, 167 .

\section{I}

Ibsen, Norwegian dramatist, 75 , 199.

Ignatev, 23I.

Illyria, 24-5.

India, Indian(s), Anglo-Indian Empire, Hindustan, 96, I39$40,194,237,287$.

Indian Ocean, 243. [269.

Indo-China, French Empire in,

Inkerman, battle of, 86 .

Insurance, Old Age, 2 I 3.

Ionian Islands, 39.

Irving, Henry, actor, 199.

Isfahan (Ispahan), 266. 
Isonzo, river and basin of, 308 . Italy, Italian(s), 44, 45, ror, I02, I10; Union of, 98-III passim; Central, 103, 107; North Italian Campaign of I859, 105-6, I73; I. and Triplice, 232 ; I. movement towards French Alliance, 275; I.'s colonial expansion, 274; party of 'Young Italy,' 108, 276; Italian - Turkish War, I91 I, 276 ; neutrality in War, 1914-15, 282; entry into War, 1915, 291; reverses, 308; war-weariness, $3 \mathrm{II}$.

Ivangorod, fortress, $29 \mathrm{I}$.

Jameson Raid, 249.

Japan, Japanese, 169, 249, 252, 254,264 ; J. and War of 1914 , 282 ; J. and Germany, 257.

Jellicoe, Admiral, 303.

Jellachich, Count, 68.

Jena, battle of, 182 .

Jerome Bonaparte, Prince, 'PlonPlon,' 103.

Jerusalem, 309.

Jevons, economist, etc., 200.

Jews in Russia, 277.

Jutland, peninsula, 138 ; battle, 298,302 .

\section{K}

Kabul, 238.

Kalisch Treaty, 2 I-2.

Kandahar, British occupation and retirement, 233, 261.

Karlsbad, 52.

Kars, fortress of, 54, 89-9o, 97. Katkov, Russian publicist, 231. Katzbach, battle of the, 27.

Keller, G., German novelist, 97. Kemble, J. M., English historian, 72.

Kerch, straits of, 312. [306-7. Kerensky, Russian statesman,
Kharkov, 312.

Kherson, 312.

Khilkov, Prince, Russian statesman, 271 .

Khiva, 238.

Kiao-Chow. See Shantung.

Kiel, I33, 135; Prussian control of, r 40 ; Naval mutiny at, 329.

Kiev, 125, 312.

' Kilimanjaro line,' 263.

Kinglake, A. W., English historian, 74 .

Kingsley, Charles, English novelist, poet, religious leader, 97 .

Kinsale, Old Head of, 294.

Kirman, Persian province, 266.

Kissingen, 154 .

Kitchener, Earl, Marshal, 264.

'Klein Deutsch,' I 30, 143.

Kolkand, Khanate of, 169.

Königsberg, 18, 284.

Königgrätz (Sadowa), battle cí, I5I-6.

Korfu, Corfu, 293.

Kossuth, Louis, Hungarian statesman, 69-70.

Kovalevsky, Russian scientist, 199.

Kovno, 12.

Kronstadt, 248.

Kruger, President, $25^{\circ}$.

Kulm, battle of, 26 .

'Kulturkampf,' 200, 21 I.

Kut-ul-Amara, siege and recapture of, 294, 309.

\section{L}

Lachmann, K., scholar, 7 I.

Laibach, 52.

La Marmora, Italian statesman and general, 145 .

Lander, brothers, explorers, $7 \mathbf{I}$.

Langensalza, $\mathbf{I}_{52}$.

Laon, fortress of, 317 .

Lassalle, Ferdinand, socialist leader, 2 II.

Lauenburg, Duchy of, I33, I4U. 
Lausanne, Treaty of, 276.

Lawrence, John, 237.

Lawrence, St., river, 234.

Leboeuf, Marshal, I84.

Legnano, fortress of, 106.

Leipzig, 28-9.

Lemberg, 284 .

Lenin, Ulyanov, Russian Bolshevik leader, 3 II.

Leo XIII., Pope, 2 I I.

Leopold, Prince of Hohenzollern, I 76, I 77, I 79.

[125.

Leopold, King of the Belgians, Letts, 272.

Libau, 200, 291.

'I iberation, War of,' I14, I49.

Lichnowsky, Prince, a mbassador, 259.

Liége, city, 186, 282.

[200.

Lie, Jonas, Norwegian novelist,

Ligny, 3 I-2.

Lightfoot, Bishop, scholar, 199.

Lithuania, 59, 312.

Lille, city, 286, 317 .

Lister, Lord, 199.

Livingstone, David, explorer,

Livonia, 308, 312.

Lloyd George, D., British Premier, 304-II.

Lodz, city, 286, $29 \mathrm{I}$.

Loftus, Lord, diplomatist, I8I.

Lombardy, 102-3; ceded to Italy, I05, 107.

London Conferences (1867, I871, etc.), 96, I72, 194; London Protocol and Treaty, 134, 137 ; London Times, II3, 207.

Lorraine, $183,184,189$.

Louis XIV., 187,281 .

Louis XVIII., $5 \mathrm{I}$.

Louis Philippe, King of the French, 56, 59, 62, 188 .

Lowell, J. Russell, American author and diplomatist, 200.

Lubbock, John, Lord Avebury, English archaeologist, etc., I99.

Ludendorf, General, 284, 300.
Ludwig, scientist, 199.

Lusitania, sinking of, 294.

Luther, Martin, I 5 .

Lutsk, fortress of, 298.

Luxemburg, Duchy, I 7 I-2.

Lyell, Charles, geologist, $7 \mathbf{I}$.

Lytton, Lord, 238.

\section{$\mathrm{M}$}

Macaulay, Lord, Englișh historian, politician, etc., 72 .

Macmahon, Marshal, $184-6,209$, 267.

Mackensen, Marshal, 290-2, 300-I.

M'Lennan, T. F., I99.

Madagascar, 263, 268-9.

Magenta, battle of, I05.

Magyar, $167,168,228,319$.

'Mahdi,' the, 264.

Maine, Henry, English lawyer, historian, etc., 200.

Mainz, city and fortress of, I62.

Majuba Hill, battle of, 237 .

Malta, 39.

Manchuria, Russian, 282.

Mantua, city and fortress of, I06.

Manning, H. E., Cardinal, 198.

Maoris, 236.

Marchand, Colonel, 264.

Marchfeld, plain of the, 154 .

Maria Louisa, Empress, second wife of Napoleon I., 12.

Marne, battles, 284-5, 3 I 4 .

Marsala, 108.

Masurian Lakes, battle, 286, 289.

Mashonaland, 262 .

Matabililand, 262.

Maubeuge, fortress of, 283 .

Maude, General Stanley, 309.

Maupas, 64.

Maximilian, Austrian Archduke,

'Emperor of Mexico,' 170.

'May Laws,' the Mai Gesetze of the Kulturkampf, $210,212$.

Mazzini, Joseph, and his school, I08, 173, I78, 193. 
Meaux, 285.

Mecklenburg, 147 .

Mediterranean Sea, 25I, 288.

Melbourne, city of, 235 .

Menshikov, Prince, 79-8o, 86.

Mentana, battle of, 174 .

Merv, oasis of, 239.

Mesopotamia (in War of 1914), etc., 294, 307, 309.

Messina, Straits of, Iog.

Metternich, Prince C., Austrian Chancellor, 24, 50-2, 66, 68.

Metz, city, fortress, 96, 184, 189, I91 ; ' army of,' I84.

Meuse, river, 283.

Mexico, 169.

Mill, John Stuart, English philosopher, etc., 72.

Milman, H. H., Dean, Church historian, etc., 97.

Milyukov, Paul, Russian Foreign Minister, 306.

Milyutin, Russian statesman, 127-8.

Modlin, fortress of, 291.

Moldavia, zor.

Moltke, Helmuth, Count, Marshal, 99, I14, 148, I49, I 51, I 80, I 82, I 85, I 87 .

Mommsen, T., German historian of Rome, 97, 200.

Monastir, 293.

Monroe, James, American President, and $M$. doctrine, 170, $234,258,382$.

Mons, battle, retreat, 283 .

Montalembert, historian, politician, etc., II 2.

Montebello, battle of, 105.

Montdidier, 298, 314.

Montenegro, 21 3, 220, 224 ; marriage alliance with Italy, 275 ; entry into War of 1914, 287, 293.

Moreton Bay, 235.

Morier, Robert, diplomatist, 140, I 74, 194, 208.
Morocco, and French eccupation of, $258,265,270,282$.

Moscow, Campaign of 1812 (esp. retreat from), 9, I I-I 6 .

Moselle (Mosel), I 83.

Motley, J. L., historian, 97.

Mukhtar Pasha, 21 5, 216.

Müller, F. Max, German scholar, 112.

Munich, i54.

Murat, line of, ro3.

Muravev ('Muravieff ') Russian Count, Governor of E. Siberia, ' conqueror of Amur,' 89-90; - - (another) Rus. Count, statesman, "winner of Port Arthur,' 253.

\section{$\mathrm{N}$}

Namur, 283.

Nancy, 286.

Naples, Kingdom and city of, 103, 108-9.

Napoleon I., the Great, Emperor of the French, 'Napole. onic Empire,' etc., 9, I I-33 passim, I9I.

Napoleon III. (Louis Napoleon), Emperor of the French, 10, $63-5,73-8,83,87,91-2,97$; and Italy, 100-II3 passim; relations with Bismarck, 143 , 155; feelings towards Ge:many, I6I, I 70, I 78 ; fall, 186. Narew, river, and line of, 291.

Nassau, Principality of, 159.

Natal, 236.

'National Liberals ' of Germany, I65, 2 I 2.

Naval blockade of Germany, Austria-Hungary, etc., 288, 294, 302 (1914-18); of British Isles, 294, 298.

Navarino, battle of, 53 .

Neanderthal skull, 97.

Neuve Chapelle, battle of, 290 .

Neva, river, 308. 
New Britain, 243.

New Ireland, 243.

New Guinea, 243.

New South Wales, 235, 236.

New Zealand, 236.

Newman, John Henry, Cardinal, poet and religious leader, 200.

Nice (Nizza), 103, 107, 126.

Nicolas I., Tsar of Russia, 5I, 53-4, 59-6o, 69-7o, 75, 89, 95, 99, I34, 231,271 .

$[305$.

Nicolas II., 27I-2; abdication of,

Nicolas, Grand Duke, Russian commander I914-I 5, 252, 289.

Niemen (Nyeman), river, 12, 16, 18.

Niger, river: (Upper), 239 ; (Lower), 252; Royal Niger Company, 263.

Nigeria, 244, 263.

Nihilism, Nihilist(s), 248, 27 I.

Nikolsburg, Peace arrangements or preliminaries of (I 866), I 59 .

Nile, river, II 2, 245, 25I, 264.

Nish, city of, 292.

Nordenskjöld, Baron, Swedish explorer, geographer, etc., 201.

' Nord Deutsche Bund,' North German Confederation, I6o, 166. See also Germany.

North-West Territory, 235.

Norway, 39.

Novara, 69.

'November Constitution' (for Schleswig-Holstein), 134, 136. Novo-Rossiisk, 317.

Noyon, 285, 313.

Nuremberg, 154.

Nyasa (Nyassa), Lake, I 12.

O

Obrenovich (Serb.) dynasty, 274.

Oder, river, 18.

O'Connell, Daniel, 'the Liberator,' 55-6r.

Odessa, city of, 312.

Oesel, island of, 308 .
' Old Catholics,' I12, 212. See also Catholic.

Ollivier, Emile, French Premier, I 81,184 .

Olmütz, 70, 78, 180, 226.

Oppert, German historian, 112.

Orange Free State, 237.

Orsini (assassin), ror, 197.

Orvieto, i ro.

Osman Pasha, 215-6.

Ostend, 286.

Otto the Great, 190.

Owen, naturalist, 199.

Oxus, river, 239.

$P$

Pacific Ocean, 234.

Palacki, Bohemian historian, 71 . Palermo, I08.

Palmerston, Lord, British Premier, 58, 82, 91, 96; P. and Danish Question, I26, I32, I 36-8.

Pamir, 239.

Pan-Slavonic, Pan-Slav, 230.

Papacy, Papal States, Patrimony of Peter, 103, IIo.

Paris, 30-I ; Congress and Treaty of $1856,92,94,96,97$, I 01 , 104, 193, 194; surrender of and German entry into (1871), $187-9$; Paris in the War of I9I 4-18, 283, 3I4, 315. [199. Paris, Gaston, French scholar, Pasteur, Louis, French scientist, I I 2, 199.

Passchendaele ridge, 309.

Paskyevich, Marshal, Prince, 54.

Paul, Tsar of Russia, I22.

Pélissier, Marshal, 90.

Peronne, 307, 313.

Penjdeh (Panjdih), 239.

Persia(n, ns), 54, 95, 239.

Persian Gulf, 294.

Peschiera, fortress of, 106.

Peter (Karageorgevich), King of Serbia, 257. 
Petrograd (St. Petersburg), I:7, 308.

Philippine Islands, 257.

Philippopolis, 217.

Picquart, General, French War Minister, 269.

Piedmont-Sardinia, 42-3, 88-9o, 91, 94, 103 (Crimea), 98, rooIII. (Italian unity).

Pinsk, 292.

[110, 210.

Pius IX., 'Pio Nono,' Pope, Plassey, battle of, 195.

Pless, 305.

Pleswitz, Armistice of, 24.

Plevna, 215-16.

Plombières, meeting (Napoleon III., Cavour), ro2-4. [283. Foincaré, R., French President, Points, the Four (1 854), 84-6.

Poland, Poles, Polish, Warsaw Grand Duchy, I1, 12, 16, 18, $22,25,36-8,41,44,59-60,91$, 123-4, 272, 286, 312; Polish insurrections, 59-60, 120-1.

Poltava, 312.

Pomerania, 37, 39, 288.

Poniatowski, Prince, 29.

Pondicherry, Pondicheri, 240.

Port Alexander III. (Libau), 291 . Port Arthur, 252; (Russian), 264. Port Jackson (Sydney), 235.

Port Philip, 235.

Portugal, Portuguese, 314.

Posen, 239.

Prague, 154; Peace of, 159, 164. Pripyat (Pripet) Marshes, 292, 298.

Prussia, Prussian(s), I 1, I2, I4, 16, 17-33, 36-9, 52, 78, 84-5, 94, 99-1 21, I60, I82; A ustrian Entente with P., I29; P. supremacy in Germany, 159163, 173; P. Diet, I14-17, 119,164 .

Pruth, 84.

Przemysl, Peremyshl, fortress of, 284, 291.
Pusey, Dr., theologian and religious leader, 198.

Pushkin, Russian poet, 7 I.

Quadrilateral, Italian, I06-7 ; Polish, 291 ; Balkan, 84, 260, 301.

Quatre Bras, 32.

Queensland, Colony of, 235.

Quentin, St., 307, 313, 317.

Quetta, 238.

\section{$\mathbf{R}$}

Ranke, Leopold, German historian, I14, I 87 .

Rechberg, Count, Austrian statesman, 129-31, 136, 140, 183.

Redan (Sevastopol), 91.

Red Sea and coasts, 274.

'Red Shirts,' 109, 174.

Reform Bills, British (1832), I95 : (1867), 195; (1885), I6r.

Reggio, 109.

'Reichsland ' of Alsace-Lorraine ('Elsass-Lothringen '), I 89.

Reichstadt, Convention of, 214 , 220, 224.

Reichstag (of North German Confederation and of New German Empire), 166, I67, 303.

'Re-insurance' Treaty, (RussoGerman), 230, 233, 248.

Reval Agreements (AngloRussian), 256, 274.

Rheims, Reims, 285, 31 I, 316.

Rhine, river, basin, 29, 30,38 ;

Confederation of the, 25, 27, 29.

' Rhenish Prussia,' 38.

Rhodes, Cecil, British African statesman and financier, 262. Riga, city and gulf of, 292, 308 . Rigsrad, Danish Parliament, 136. 'Risorgimento' (Italian Unity). I08. 
Ritschl, A., German theologian, 200.

Riviera, Italian, 108.

Roebuck, J. A., English politician, etc., 77.

Rohlfs, G., German explorer, etc., 199.

Rome, Roman(s) : city of, 103, 193: Church of, in France, 270 ; Roman (Papal) 'Patrimony,' I 10.

Romagna, 106.

Roon, Count Albrecht, Pussian Marshal and War Minister, 99, II 4, I1 5, I I 7, I48, I80.

Rosebery, Earl, British Premier, 262.

Rosegger, Styrian novelist, 200.

Rostov-on-Don, 312.

Rossetti, D. G., 200.

Roubaix, 3I 7.

Rügen island, 37 .

Rumania, Rumanian(s), I55, $214,220,223,224,259-60$, 300-3 ; entry into World War, 1916, 299 ; advance in Transylvania, 300; retreat and defeat, 301, 303 ; R. Convention, 312 ; provinces, the 'Danubian Principalities '(Moldavia, Wallachia), 80-I, 83-4, 92-3.

Ruskin, John, English art critic, social reformer, etc., I99, 200.

Russell, Lord John (Earl), British premier, 109, 194.

Russia, Russian(s), 9-10, I I-16, 21-25, etc., 29, 35-6, 49, 59-60, 73-97, 99 I Russian-Prussian (German) relations, 18-22, 37 , $78,81,173-4,194,204,206-7$, 226-232, 247-8; R. in Asia, $237-9,264$; French alliance with R., 268, 278; internal Movements and Reforms in, 123, 173, 271, 276; Little Russia, 312; Great Russia, 312; Bulgarian alliance with,
277; R.-Turkish War, 96, 209, 214 ; R. Poland, resettlement of, 127-8; Red R. (Ruthenians), 277; $R$. and the War of I $914,280-320$ passim; support for Serbia, 281, 283; advance and defeat in Carpathians, 290; Tsardom undermined, 292; pacificism in, 299; Revolution and Republic, 305308 ; Bolshevik Government makes separate peace with Germany, 3II; terms of Peace of Brest Litovsk, 312 ; Soviet system, 308-I I.

\section{$\mathrm{S}$}

Saar, valley of, 183,184 .

Sadowa. See Königgrätz.

Saint Arnaud, 64.

Salamanca, battle of, 17 .

Salerno, rog.

Salisbury, Marquess (Robert Cecil), British premier, I39, 203, 22I, 232, 233, 248, 263. Salonika, Thessaloniki, in War of I914-18, 293.

Sambre, river, 283.

Samoa, 24I-2, 255.

San Stefano, Treaty of, 95, 219 , 220, 223.

Sardinia, S.-Piedmont, House of Savoy, see PiedmontSardinia.

Saxony, Kingdom of, 23-4, 26-9, $37-8,41,128,147,160$; Saxon Switzerland,' I 50.

Scharnhorst, Prussian general and reformer, 21, 23, 114 .

Scheer, Admiral, 302.

Schiaparelli, 199.

Schleswig - Holstein, 'Elbe Duchies,' 'Danish Question,' 129, I32-9, I59.

Sedan, battle of, 95, 185, 186, 226, 289.

Seeley, J. R., I96, 198 
Serbia, Serbian, Serb(s), 54-5, $213,220,224,259-60,266$, 276-280 passim; S.-Bulgarian Treaty, 277 ; S. and War of I914, 279-80, 292-3, 318.

Sereth, river, 301 .

Sevastopol, city fortress, its siege (1854-5), 82, 85-90, 216.

Seven Weeks' War, I50, I64, $167,176$.

Seven Years' War, 228.

Shantung, 282, 287, 294.

Shipka Pass, 215-6.

Shuvalov, Count Peter, Russian statesman, 221.

Siam, 270.

Siberia, Siberian Railway, 271. Sicily, the Two Sicilies, ro3.

'Siebenburgen' (Transylvania), 300.

Siemens, steel manufacturer and inventor, 97.

Silesia, 23-4, 26-7, I 50, 286.

Silistria, fortress of 'Danubian Quadrilateral,' 84, 260, 301 .

Sinope, battle ('Massacre '), 82 .

Skager Rak. See Jutland.

Skobelev, General, 21 5, 238.

Smolensk, I5, 125.

Sobieski, John, Polish King, 94. Soissons, 314.

Soliman the 'Magnificent,' Sul$\tan$ of Turkey, 276.

Solovev ('Solovieff'), Russian historian, 75.

Somali-land, Italian protectorate of, 274 .

[299, 314 .

Somme, river, campaigns on the, Soviet. See Russia.

Spain, Spanish, Spaniard(s), I 7 , $22,25,245,303$; S.-American War, 257. Seealso Hohenzollern Candidature for S. Crown.

Speke, explorer, 97, II2.

Stambul. See Constantinople.

Stambulov, Bulgarian statesman, 224.
Stein, Baron, Prussian statesman, 14,46 .

[188-9.

Strassburg, Strasbourg, I84, Stratford de Redcliffe, Lord (Stratford Canning), 79-80, 82, 92.

Stubbs, Bishop William, English historian, etc., 296.

Submarine campaign in War of $1914-18,288,294,302,305$.

Sudan, 263, 268 ; Central S., 270. Suez Canal, 213 ; Turkish attack on, 294.

Suvorov, Russian Marshal, 215.

Sweden, Swedish, Swedes, 22, $35,37,39$.

Switzerland, 303, 309.

Sydney, city of, 235 .

Syria, British offensive in (1917I8), 309, 316, 317 .

$T$

Tabriz, city, 265 .

Tanganyika, Lake, 97.

Tannenberg, battle of, 284 .

Tarnopol, city of, 308 .

'Taurida,' Russian province of, 91.

Tauroggen, Convention of, 18 .

Tashkent, city, 244.

Tasmania, 235.

Teano, i Io.

Tehran, 'Teheran,' Tihran, Persian capital, 265 .

Terracina, I Io.

Thackeray, W. M., English novelist, etc., 72 .

Tennyson, Lord, poet, 75 .

Theodoric, the Ostrogoth, II I.

Thiers, Adolphe, French statesman, I 71, I82, 186, I91, 208-9.

Thorn, city fortress, 18,37 .

Thrace, 316.

Thuringia, $T$. states, 160 .

Tibet, 96, 266.

Tigris, river, 294, 307.

Tirga-Jiu, battle of, 301 . 
Tischendorf, C., German theologian and scholar, 72, II2.

Todleben, Russian general, 86 , $90,216$.

Togoland, 243, 294.

Tolstoi, Count Leo, Russian author and religious reformer, I 12.

Tonking, 268.

Toul, city and fortress of, 286 .

Toulon, city and port of, 248 .

Trades Unions, 201, 267.

Transvaal Republic, 236, 246, 261.

Treitschke, H., German historian, I67.

Trieste, city and port of, 308 .

Triple Alliance, 'Triplice,' 206, 229, 233, 253, 275, 291.

Triple Entente, 256, 258, 265-6, $269,274,278$.

Tripoli, 275.

Trotsky, Russian 'Bolshevik' leader, 311 .

Troppau, 52.

Tuileries, Palace of the, I04.

Tunis, 239, 282 ; French seizure, 268.

Turcoing, 317.

Turin, city of: parliament of Piedmont-Sardinia at, III.

Turkey, Turks, 'Sublime Porte,' Ottoman Empire, 79-80, 82-5, 92-7; T. and War of r914-1 8 , 287-320 passim; entry into War, 287; gains by Brest Litovsk Treaty, 312 ; Samaritan front broken, 317 ; sues for peace, 3 I 9 .

Turkistan, Turkestan, Russian conquest of, 169, 237-8.

Tutrakan, fortress of, 301 .

Tylor, E. B., British anthropologist, 199.

Udine, 309
Ukraine, 59.

Ultramontane. See Catholic.

Umbria, 206, I 10.

Union, Canadian, Act of 1867,235 .

United States (of America). See America.

\section{V}

Vandammes, French Marshal, 26.

Varennes, 285.

Varna, port of, 84 .

Vatican Council, 209-10.

Vauxaillon, 309.

Venice, Venetia, Venetian(s), 36 ; I01, 102, 107, 108, I10, I44, 154; Venetian Alps, 309.

Venizelos, Eleutherios, Greek statesman, 293.

Verdun, fortress, siege (1916), 128, 283, 285, 296, 299.

Verona, 52, 106; Austrian advance on, 298.

Versailles, New German Empire proclaimed at $(187 \mathrm{I}), 189$, I92.

Vicenza, 298.

Victor Emmanuel II., first King of New Italy, 103, 104, 106, 107, I I0, I73, I75, 193.

Victor Emmanuel III., King of Italy, 275.

Victoria, British Queen, 58, 798o, 84; her interest in Prussia, I00; on Austria, I05; on Polish Question, 125; Bismarck and, 207, 256.

Victoria, Crown Princess of Prussia (Empress Frederick), Ioo.

Victoria Nyanza (Ukerewe), Lake, II2.

Victoria, Australian Colony of, 235.

Vienna, Vienna Govt., etc., $3 \mathbf{1}$, 34, etc., 68, 80-I, 104, II 4.

Vienna Act (1820), 52. 
Vienna Congress, Treaty and Peace Settlement (1814-15), 3I, 34-47, II 4, I 2 I, 133.

'Vienna Note of,' 8r.

Vienna Peace of 1864, 138-9.

Villa Franca, Peace Preliminaries of, $107, \mathrm{II}_{3}, \mathrm{II}_{4}, 197$.

Vilna, capital of Lithuania, Russian provincial city, 292.

Vistula, river, 18, 284 ; Russian provinces of, 127.

Vitebsk, city of, 125.

Vittoria, battle of, 25.

Volga, river, 123.

\section{W}

Wadai, Sultanate of, 251.

Waldeck-Rousseau, P. M. R., French statesman, 270.

Wallace, Alfred R., scientist, II2.

Wallachia, plains of, 3 or.

Warsaw, 59-60, 124 ; in war of ror $4-18,286,29 r$.

Washington, city of, 305 , 306.

Waterloo, battle of, 32-3.

Wei-hai-wei, harbour of, 264.

Weimar, 147.

Weissenburg, 183.

Wellington, Duke of, 17, 25, 30-33, 55.

Westphalia, 38, 41-2 ; Peace of, 156.

Wilson, Woodrow, President of U.S.A., 295, 304-6.

William I., Regent and King of Prussia, German Emperor: character, 98; Regent, 99; King, 114 ; proposed abdication, II 1 II7; appreciation of Bismarck, I4I ; W. and Austria, 142, r 44, 151, 159; 162 ; and Hohenzollern (Spanish) Candidature, $177-9$; and Ems telegram, 180-1; in French war, 183, etc.; declared Emperor at Versailles, I92; and Tsar Alexander II., 226.

William II., Prussian King, German Emperor, 225, 229; Austrian policy of, 230; character, 246, 250, 255; friendship with Nicolas II. of Russia, 252; attitude in Boer War, 254; attitude to France, $265 ; \mathrm{W}$. and War of r914, 28I ; connection with Greece, 293 ; militarism of, 295, 313; abdication of, 319.

Windischgråtz, Prince, 68.

Wiseman, Cardinal, 198.

Wittenberg, 37 .

Witu, 263.

Wörth, battle of, 184 .

Württemberg, r62.

Würzburg, I54.

Wyndham, C., 199.

\section{$\mathbf{Y}$}

Yorck, Prussian Marshal, 18-20. Young, Arthur, English farmer, traveller, and writer, r91.

Yugo-Slav ideals ('Great Serbia '), 260.

Yule, H., historian, geographer, etc., 199.

Ypres, 286, 290, 309, 314.

\section{Z}

Zambezi, river, 97, 245.

Zanzibar, island, city, 243, 262.

Zeebrugge, 31 7 .

Zemstvo system, 123.

Zola, E., French novelist and politician, 200, 269.

Zollverein, Prussian (and German), 140, 148, I71.

Zurich lake dwellings, 97.

Zululand, 336. 

(a) 


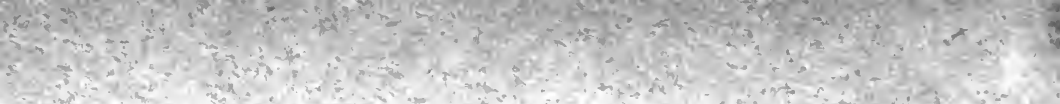

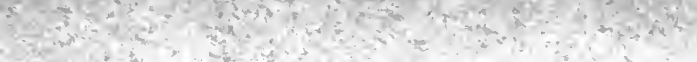
of at 


\section{PLEASE DO NOT REMOVE \\ CARDS OR SLIPS FROM THIS POCKET}

\section{UNIVERSITY OF TORONTO LIBRARY}

D

359

B4

Beazley (Sir) Charles Raymond Nineteenth century Europe and Britain 


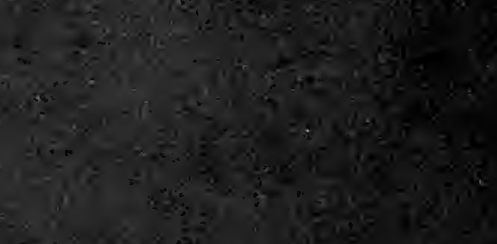

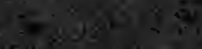

$\therefore$

$i^{5} 3:$

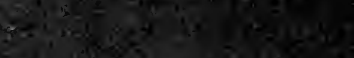

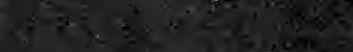

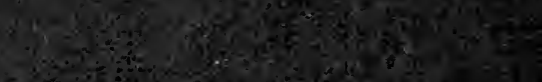

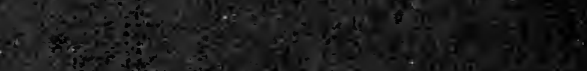

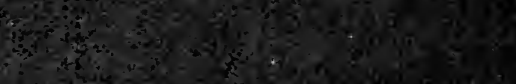

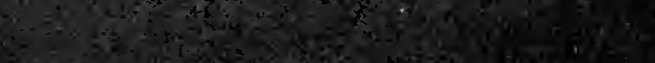

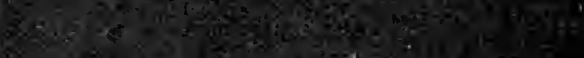

$\therefore$ and

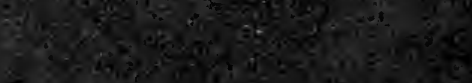

C.

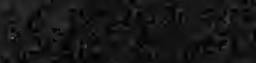

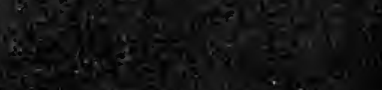

